a

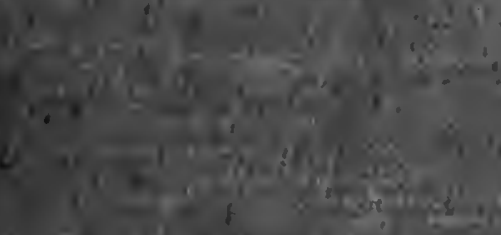

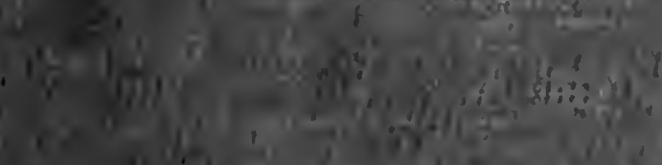

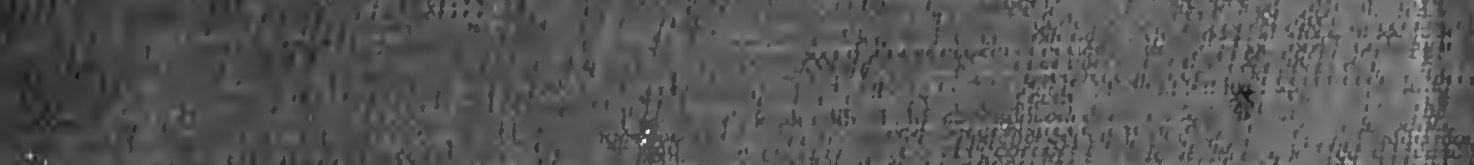

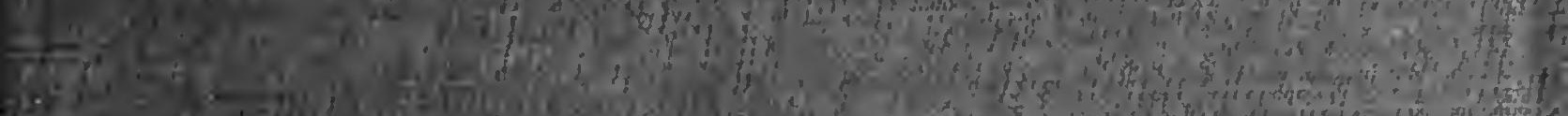

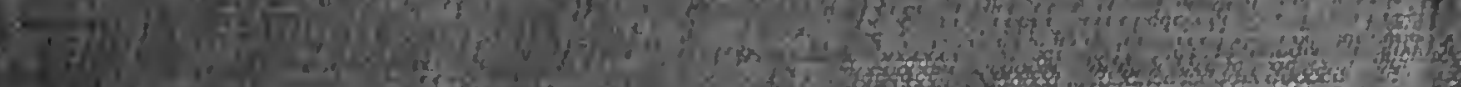
Q.

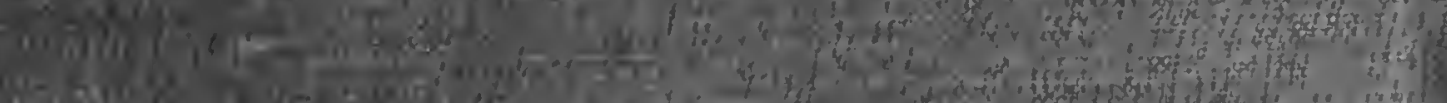
(110,

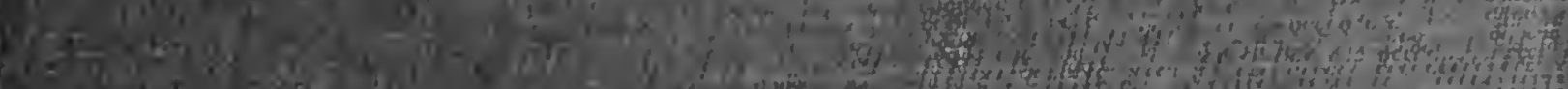

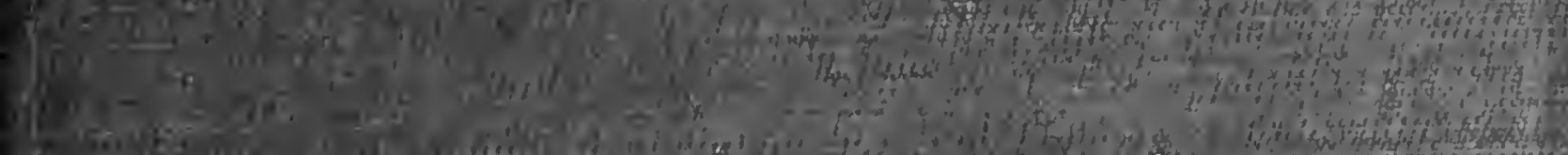

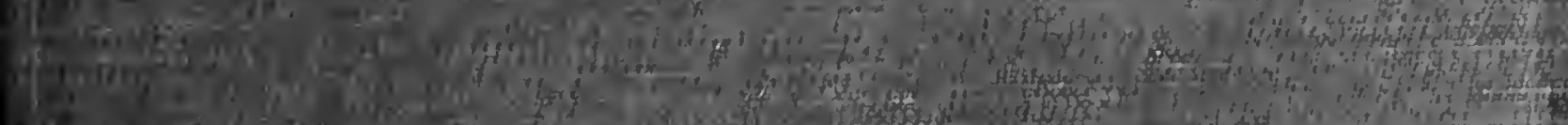

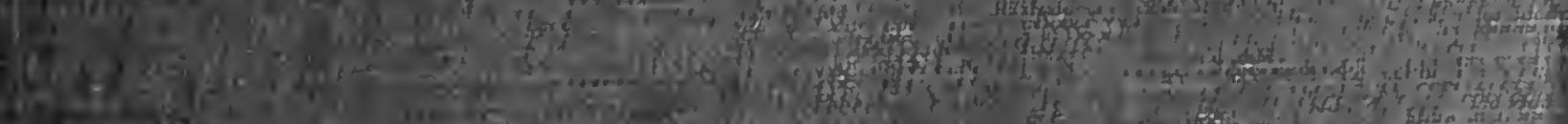
(1)

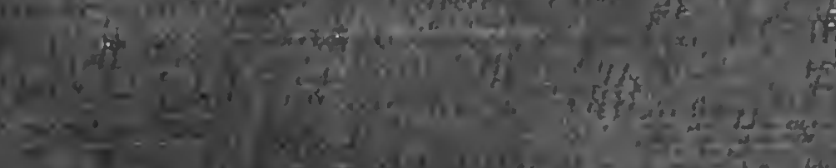

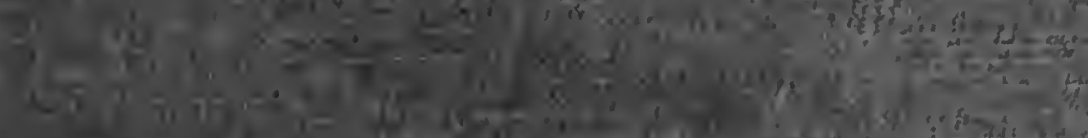

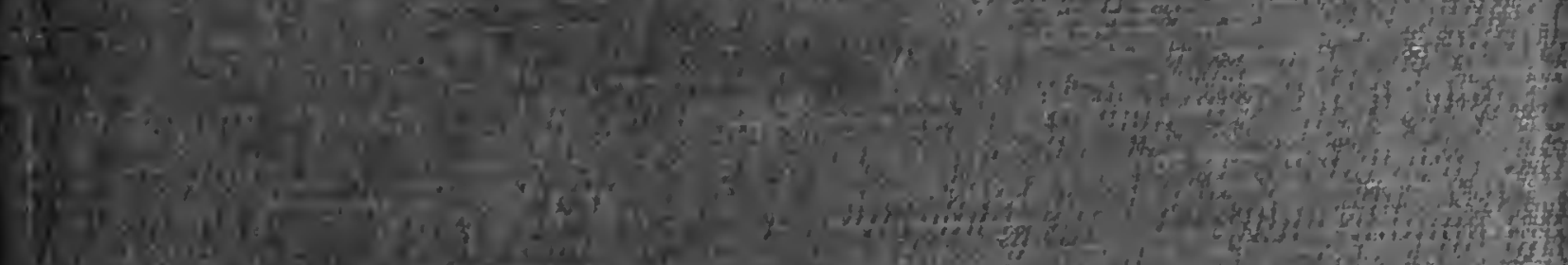

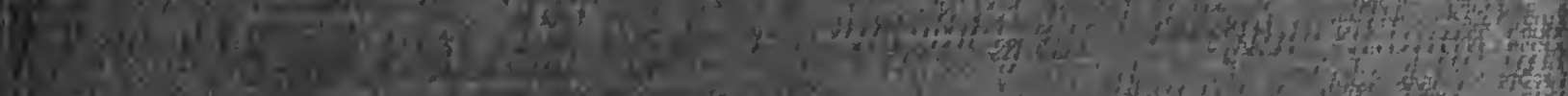

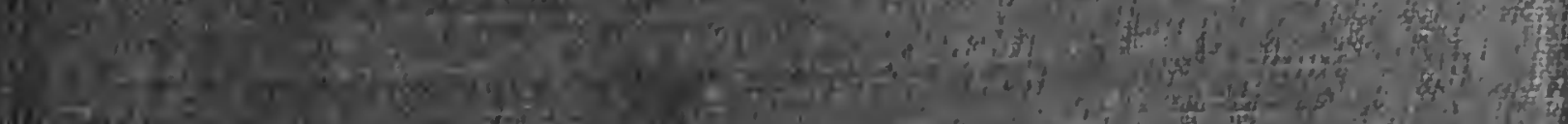

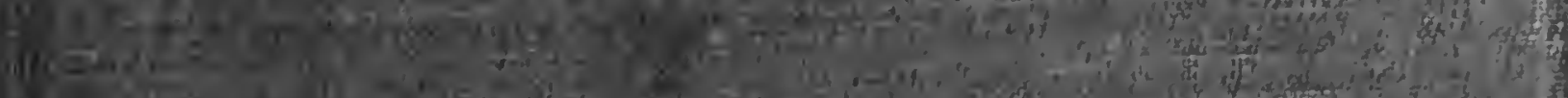

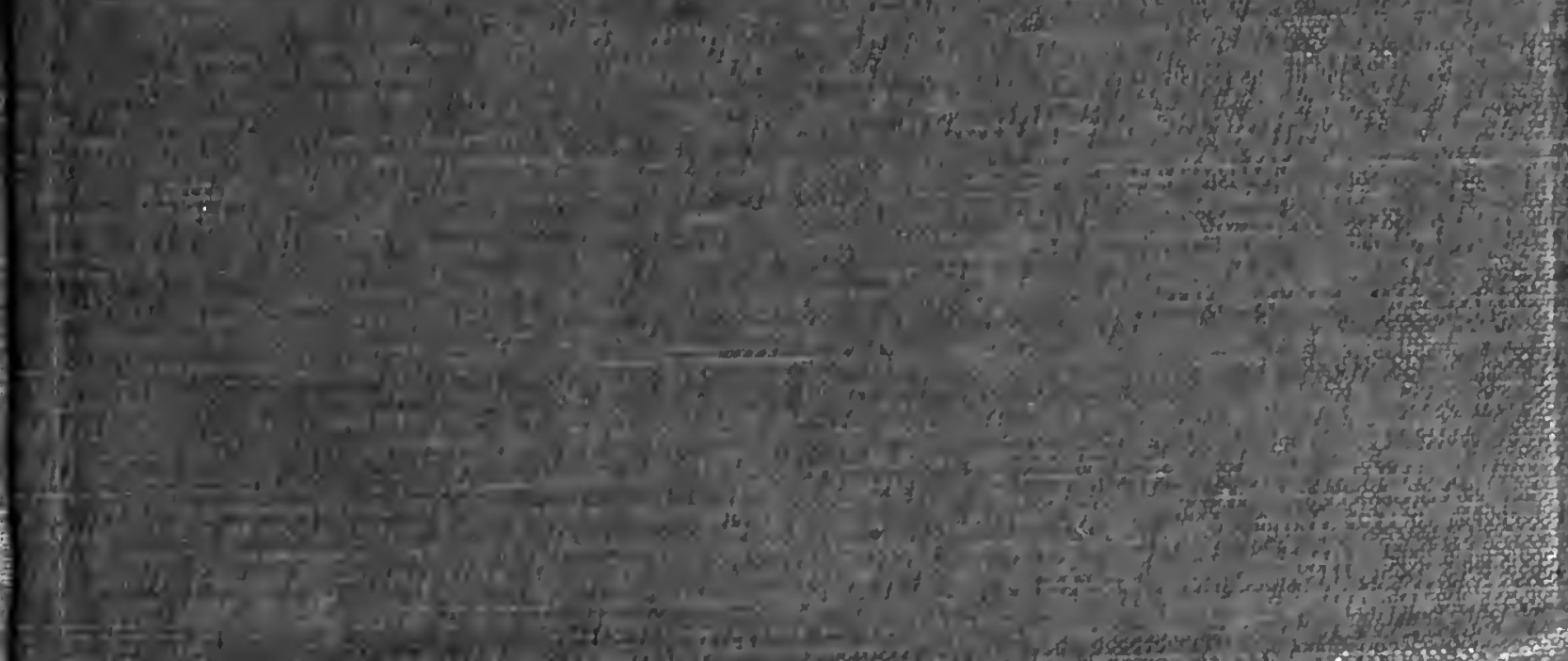




\section{Digitized by the Internet Archive in 2008 with funding from Microsoft Corporation}




\section{.}





\title{
GREATER EUROPEAN GOVERNMENTS
}

\author{
BY \\ A. LAWRENCE LOWELL \\ PRESIDENT OF HARVARD UNIVERSITY
}

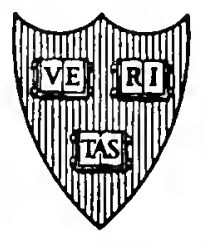

CAMBRIDGE

HARVARD UNIVERSITY PRESS

I 9 I 8 
254

COPYRIGHT, Iq 8

HARVARD UNIVERSITY PRESS 


\section{PREFACE}

To take a second exposure on a photographic plate, in order to make the picture more accurate, is apt to have the opposite effect. Attempting to bring a description of social conditions or political institutions up to date is more often undertaken, but hardly with greater success; and when it is done in a hurry the defects are increased. Yet the demand for a book dealing in a moderate compass with the governments of the principal belligerents in Europe came so suddenly that it could be met only by using existing material with such few additions and corrections as seemed of primary importance. This volume is an abridgment of the author's "Government of England " which was published ten years ago, and of his "Governments and Parties in Continental Europe" published more than twenty years ago. Until this war the general traits of the political systems therein portrayed had altered little; and although some changes that have occurred since the war have been incorporated, there has been no attempt to cover the conditions brought about by the war. The object has been to show how those governments operate normally in time of peace, not how they have adjusted themselves to intense military stress.

While it is believed that all important alterations that have taken place in the governments of the countries 
described since the original publication have been referred to in the notes or embodied in the text, doubtless some minor ones have been passed unheeded; and the lack of time has prevented a revision and carrying down to the present day of the authorities cited in the notes. The purpose of the book is to serve an immediate end: that of giving to the members of the War Aims Course in the Students' Army Training Corps, and to the many people in this country who take for the first time an interest in foreign nations, a picture of the principal governmental systems in Europe.

The writer desires to thank the Macmillan Company for the permission to use extracts from the "Government of England "; and Dean Henry A. Yeomans of Harvard College for revising the chapters on France and Italy.

Cambridge, Massachusetts

November 5, I9I 8 


\section{CONTENTS}

\section{CHAPTER I \\ ENGLAND: CROWN AND CABINET}

Sources of the English Constitution . . . . . . . . . 3

The Relation of Law and Custom . . . . . . . 4

Powers of the Crown . . . . . . . . . . . . 5

Legislative Power . . . . . . . . . . . . . 5

Executive Power . . . . . . . . . . . . . . 7

Wide Extent of the Royal Power . . . . . . . . . 9

Powers of the Crown exercised by Ministers . . . . . . . ro

The King can do no Wrong . . . . . . . . . . . . . . I I

The Nature of Modern Responsibility . . . . . . . . I3

The King must Follow the Advice of Ministers . . . . . 14

For What Acts Ministers are Responsible . . . . . . I 5

Utility of Monarchy . . . . . . . . . . . . . . I7

Nature of the Cabinet . . . . . . . . . . . . I9

The Need of Unity and Secrecy in the Cabinet . . . . . 20

The Prime Minister . . . . . . . . . . . . 22

The Cabinet and the Ministry . . . . . . . . . 22

The Executive Departments . . . . . . . . . . 23

The Permanent Civil Service . . . . . . . . . . . 24

Appointment by Competitive Examination . . . . . . 26

Lay Chief and Expert Subordinate . . . . . . . . . 27

The Relation between Them . . . . . . . . . . 27

\section{CHAPTER II}

\section{ENGLAND: PARLIAMENT}

The Reform Acts . . . . . . . . . . . . . . 29

The Act of 19I8. . . . . . . . . . . . . . . . . 30

The Constituencies: Boroughs and Counties . . . . . 30

The Universities . . . . . . . . . . . . . . . 3 I

The Franchise: Parliamentary for Men . . . . . . . 32

The Local Franchise for Men . . . . . . . . . . 32

The Franchise for Women . . . . . . . . . . . . 33

Candidates and Elections ............ 34 
The Commons' House . . . . . . . . . . . . . 35

The Speaker . . . . . . . . . . . . . . 35

The Committees . . . . . . . . . . . . . 36

The Committee of the Whole . . . . . . . . . 37

Select Committees . . . . . . . . . . . . . 38

Standing or Grand Committees . . . . . . . . . . 40

Procedure on Public Bills . . . . . . . . . . . . . . $4 \mathbf{I}$

Procedure on Money Bills . . . . . . . . . . . . . 42

The Budget . . . . . . . . . . . . . . . . . . 45

The Public Accounts . . . . . . . . . . . . . . . 45

Framing Legislative Questions . . . . . . . . . . . 47

Private Members' Bills . . . . . . . . . . . . . . . 49

The Cabinet's Control of Legislation . . . . . . . . . . . 50

The Commons' Control over Administration . . . . . . $5^{\text {I }}$

Criticism and Censure . . . . . . . . . . . . 52

Parliament the Inquest of the Nation . . . . . . . 54

Private Bill Legislation . . . . . . . . . . . . . . 55

The House of Lords . . . . . . . . . . . . . . . . . . . 57

The Powers of the House of Lords . . . . . . . . . . . 59

The Act of IgII . . . . . . . . . . . . . . 60

The Cabinet and the Country . . . . . . . . . 6r

\section{CHAPTER III}

ENGLAND: PARTY

Parties during the War . . . . . . . . . . . . . . . 63

Parties in Modern Government . . . . . . . . . . . . 64

Party and the Parliamentary System . . . . . . . 64

Party Votes in Parliament. . . . . . . . . . . . 66

\section{CHAPTER IV}

\section{ENGLAND: LOCAL GOVERNMENT}

The Areas of Local Government . . . . . . . . . . . . . . 69

Borough Councils .. . . . . . . . . . . . 7 I

The Mayor . . . . . . . . . . . . . . . . 73

The Permanent Officials . . . . . . . . . . . 73

Their Position . . . . . . . . . . . . . . . 74

Benefits of their Influence . . . . . . . . . . . . 76 


\section{CHAPTER V}

ENGLAND: THE EMPIRE

The British Empire . . . . . . . . . . . . . . . 77

Proportion of Races . . . . . . . . . . . . . . . 77

Distribution of the European Elements . . . . . 78

Revenue . . . . . . . . . . . . . . . 79

Forms of Colonial Government . . . . . . . . . . . 80

The Self-Governing Colonies . . . . . . . . . . 80

Colonial Federations . . . . . . . . . . . . . . 82

The Relation to England . . . . . . . . . . . 82

The Crown Colonies . . . . . . . . . . . . . . . 85

India . . . . . . . . . . . . . . . . . . 86

The Civil Service of India . . . . . . . . . . . . . 87

India is not a Nation . . . . . . . . . . . . 88

The Native States . . . . . . . . . . . . . . 89

Egypt . . . . . . . . . . . . . . . . . 90

Imperial Federation . . . . . . . . . . . . . . 90

\section{CHAPTER VI}

FRANCE: INSTITUTIONS

Origin of Parliamentary Government . . . . . . . . 93

Parliamentary Government on the Continent . . . . . . . . 97

The French Constitution . . . . . . . . . . . . . . . 98

History of its Creation . . . . . . . . . . . . . . . . 99

The Constitutional Laws . . . . . . . . . . . . IOI

Amendments . . . . . . . . . . . . . . 102

The Chamber of Deputies . . . . . . . . . . . . . . . 104

Scrut in de Liste and Scrutin d'Arrondissement . . . . . . 105

The Chamber a Tumultuous Body . . . . . . . . 107

The Senate . . . . . . . . . . . . . . 108

Its Functions . . . . . . . . . . . . . . . . . . . IIO

Its Actual Influence . . . . . . . . . . . . . . . I II

The President of the Republic . . . . . . . . . . . . II 5

His Personal Authority . . . . . . . . . . . . . II7

The Conseil d'Etat . . . . . . . . . . . . . . . . I I

The Ministers . . . . . . . . . . . . . . . . I 20

Their Responsibility to the Chambers . . . . . . . . . I 2 I

Their Enormous Power . . . . . . . . . . . . . . I2I 
Local Government . . . . . . . . . . . . . 122

The Prefect . . . . . . . . . . . . . . . . . . . I24

The General Council . . . . . . . . . . . . I25

The Arrondissement and the Canton . . . . . . . 127

The Commune . . . . . . . . . . . . . . . . . . . . 128

Paris . . . . . . . . . . . . . . . . $\mathbf{1} 30$

Legislative Powers of the Executive . . . . . . . . . . I3I

Decrees and Ordinances . . . . . . . . . . . . . . I3I

Appropriations . . . . . . . . . . . . . . . . . . . . I33

Judicial Powers of the Executive . . . . . . . . . . . . I34

Early Royal Power in England . . . . . . . . . . . . 135

The Judicial System in England . . . . . . . . . . . . I35

The Administrative System . . . . . . . . . . . . . . I37

The Royal Power in France . . . . . . . . . . . . . . 137

The Judicial System in France . . . . . . . . . . . . . 138

The Administrative System . . . . . . . . . . . . . . 139

Doctrine of the Separation of Powers . . . . . . . . 140

The Administrative Courts . . . . . . . . . . . . . . 143

The Court of Conflicts . . . . . . . . . . . . I47

The State of Siege . . . . . . . . . . . . I48

Effect on the Executive . . . . . . . . . . . . . . . I49

\section{CHAPTER VII}

FRANCE: PARTIES

Parties in Popular Government . . . . . . . . . . . I $5 \mathbf{I}$

The Parliamentary System and Parties . . . . . . I52

Many Groups in France . . . . . . . . . . . . . I55

The Lack of Political Consensus . . . . . . . . . . . . I58

French Political Opinions Theoretical . . . . . . . . I6 I

Effects of French Political Mechanism . . . . . . . . . I64

The Method of Electing Deputies . . . . . . . . I64

The Committees in the Chambers . . . . . . . . . I67

Interpellations . . . . . . . . . . . . . . . $\mathbf{I} 72$

Jealousy and Distrust of the Ministers . . . . . . . 178

Results of the Condition of Parties ............ I8I

The Cabinet a Coalition and therefore Weak . . . . . 182

Political Use of Offices . . . . . . . . . . . . . 184

Deputies and their Committees . . . . . . . . . 185

The Deput ies and their Constituents . . . . . . . . 188

Prospects of the Republic . . . . . . . . . . . . . . . . . 189 


\section{CHAPTER VIII}

\section{ITALY}

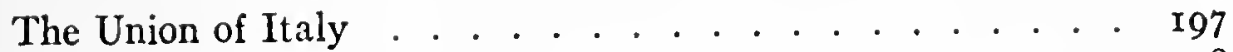

The Statuto . . . . . . . . . . . . . . 198

The King . . . . . . . . . . . . . . 200

The Ministers . . . . . . . . . . . . . . . 201

The Senate . . . . . . . . . . . . . . . 202

The Chamber of Deputies . . . . . . . . . . . . . . . 204

The Administrative System . . . . . . . . . . . 208

Contrast between Theory and Practice . . . . . . . . 2 I0

The Ordinance Power . . . . . . . . . . . . . . 2 II

The Civil Service. . . . . . . . . . . . . $2 \mathrm{I} 3$

Local Government . . . . . . . . . . . . 214

The Judicial System . . . . . . . . . . . . . . . 2 I 6

The Courts and the Officials . . . . . . . . . . . 217

Administrative Law . . . . . . . . . . . . . 218

Administrative Courts . . . . . . . . . . . . 220

Weakness of the Judicial System . . . . . . . . . 222

The Church . . . . . . . . . . . . . . . 223

Church and State . . . . . . . . . . . . . . 224

The Monastic Orders . . . . . . . . . . . . . . 226

The Pope . . . . . . . . . . . . . . . . . 227

The Law of the Papal Guarantees . . . . . . . . . . 228

Difficulty of the Question . . . . . . . . . . . . 230

\section{CHAPTER IX}

GERMANY: STRUCTURE OF THE EMPIRE

Former Subdivision of Germany . . . . . . . . . . 233

The Growth of Prussia . . . . . . . . . . . . . . 234

The Germanic Confederation . . . . . . . . . . 235

The Attempt at Union in $1848-49$. . . . . . . . . . . 236

Bismarck . . . . . . . . . . . . . . . 238

The Constitutional Conflict . . . . . . . . . . . 238

The North German Confederation . . . . . . . . . 240

The Constitution of the Empire . . . . . . . . . . . . . 242

Nature of the Confederation . . . . . . . . . . . . 243

The Privileges of Prussia . . . . . . . . . . . . . . 245

Privileges of the Other States . . . . . . . . . . 248

The Empire and the Old Confederation . . . . . . . . . 249 
The Reichstag . . . . . . . . . . . . . . 251

The Committee System . . . . . . . . . . . 253

The Powers of the Reichstag . . . . . . . . . 254

The Right of Dissolution . . . . . . . . . . 255

Interpellations . . . . . . . . . . . . . 256

The Bundesrath. . . . . . . . . . . . . . . 257

Character of the Bundesrath . . . . . . . . . . . 259

Its Internal Organization . . . . . . . . . . . 262

Powers of the Bundesrath . . . . . . . . . . . . 264

Privacy of Meetings . . . . . . . . . . . . 267

Actual Influence of the Bundesrath . . . . . . . . . 268

The Kaiser . . . . . . . . . . . . . . . . . . . . . 269

His Powers as Kaiser and King . . . . . . . . . . . 270

The Chancellor . . . . . . . . . . . . . . . 272

His Functions . . . . . . . . . . . . . . . 274

His Substitutes . . . . . . . . . . . . 275

The Judiciary . . . . . . . . . . . . . . . 276

The Reichsgericht . . . . . . . . . . . . 276

Character of the Federal System . . . . . . . . . 277

\section{CHAPTER X}

GERMANY: THE SEVERAL STATES

Prussia: The Constitution and the King . . . . . . 279

The Ministers and the Bureaucracy . . . . . . . 280

The Landtag . . . . . . . . . . . . . . . . . 282

The Three-Class System of Election . . . . . . . 283

Prussian Local Government . . . . . . . . . . . 286

Bavaria . . . . . . . . . . . . . . 286

Wurtemberg, Baden, and Hesse . . . . . . . . . . 288

Saxony . . . . . . . . . . . . . . . 289

The Small Monarchies . . . . . . . . . . . . 291

The Two Mecklenburgs .. . . . . . . . . . . . . 293

Hamburg, Bremen, and Lübeck . . . . . . . . . . . 293

Alsace-Lorraine . . . . . . . . . . . . . . 295

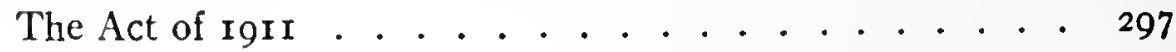




\section{CHAPTER XI}

GERMANY: COMMENTS ON THE POLITICAL SYSTEM

The Position of the Chancellor . . . . . . . . . . . . 299

Why not Responsible to the Reichstag . . . . . . 30r

Parties in Germany . . . . . . . . . . . . . . . 302

Parties in the Landtags . . . . . . . . . . . . . 304

Class Strife an Obstacle to Popular Government . . . . 305

The Growth of Discontent . . . . . . . . . . 307

Democracy would Involve Organic Changes . . . . . 308

\section{CHAPTER XII}

\section{AUSTRIA-HUNGARY}

Austria: Provinces and Races . . . . . . . . . . 3ro

The Constitution . . . . . . . . . . . . . . 312

The Emperor . . . . . . . . . . . . . . . 313

The Reichsrath . . . . . . . . . . . . . . . 313

The Provinces . . . . . . . . . . . . . . . 315

The Race Question . . . . . . . . . . 316

Hungary: The Races . . . . . . . . . . . . 3 I 8

The King . . . . . . . . . . . . . . . . 320

The Parliament . . . . . . . . . . . . . . 32 I

The Dual Monarchy . . . . . . . . . . . . . 322

The Delegations . . . . . . . . . . . . . . 323

The Customs Union . . . . . . . . . . . . 325

The Joint Ministers . . . . . . . . . . . 325

Bosnia and Herzegovina . . . . . . . . . . . . 327

The Character of the Union . . . . . . . . . . 328 



\section{GREATER EUROPEAN GOVERNMENTS}





\section{CHAPTER I}

\section{ENGLAND: CROWN AND CABINET}

\section{Sources of the English Constitution}

THE English constitution - speaking, of course, of its form, not its content - differs from those of most other European nations more widely in method of expression than in essential nature and legal effect. They have been created usually as a result of a movement to change fundamentally the political institutions of the country, and the new plan has naturally been embodied in a document; but since the Restoration England has never revised her frame of government as a whole, and hence has felt no need of codifying it. The national political institutions are to be found in statutes, ${ }^{1}$ in customs which are enforced and developed by the courts and form a part of the common law, and in customs strictly so called which have no legal validity whatever and cannot be enforced at law. These last are very appropriately called by Professor Dicey the conventions of the constitution. The two chief peculiarities of the English constitution are: first, that no laws are ear-marked as constitutional - all laws can be changed by Parliament, and hence it is futile to attempt to draw a sharp line between those laws which do and those which do not form a part of the constitution; second, the large part played by customary rules, which are carefully followed, but which are

1 Boutmy in his Eludes de droit constitutionel (Ist ed., p. 9) adds treaties or quasi-treaties (the Acts of Union), and solemn agreements such as the Bill of Rights. But all these are in legal effect simply statutes. 
entirely devoid of legal sanction. Customs or conventions of this kind exist, and in the nature of things must to some extent exist, under all governments. In the United States where they might, perhaps, be least expected, they have transformed the presidential electors into a mere machine for registering the popular vote in the several states, and this is only the most striking of the instances that might be cited. ${ }^{1}$ England is peculiar, not because it has such conventions, but because they are more abundant and allpervasive than elsewhere. The most familiar of them is, of course, the rule that the king must act on the advice of his ministers, while they must resign or dissolve Parliament when they lose the confidence of the majority in the House of Commons. It is impossible, however, to make a precise list of the conventions of the constitution, for they are constantly changing by a natural process of growth and decay; and while some of them are universally accepted, others are in a state of uncertainty.

\section{The Relation of Law and Custom}

The relation between law and custom in the English government is characteristic. From the very fact that the law consists of those rules which are enforced by the courts, it follows that the law - including, of course, both the statutes and the common law - is perfectly distinct from the conventions of the constitution; is quite independent of them, and is rigidly enforced. The conventions do not abrogate or obliterate legal rights and privileges, but merely determine how they shall be exercised. The legal forms are scrupulously observed, and are as requisite for the validity of an act as if custom had not affected their use. The power of the crown, for example, to refuse its consent to

${ }^{1}$ Bryce, American Commonwealth, ch. xxxiv. 
bills passed by the two houses of Parliament is obsolete, yet the right remains legally unimpaired. The royal assent is given to such bills with as much solemnity as if it were still discretionary, and without that formality a statute would have no validity whatever. The most notable example of this is the way in which the actual exercise of the royal power has been transferred from the king to Parliament. The House of Commons gradually drew his authority under its control; but it did so without seriously curtailing the legal powers of the crown, and thus the king legally enjoys most of the attributes that belonged to his predecessors, although the exercise of his functions has passed into other hands. If the personal authority of the monarch has become a shadow of its former massiveness, the government is still conducted in his name, and largely by means of the legal rights attached to his office. With a study of the crown, therefore, a description of English government most fittingly begins.

\section{Powers of the Crown}

The authority of the English monarch may be considered from different points of view, which must be taken up in succession; the first question being what power is legally vested in the crown; the second, how much of that power can practically be exercised at all; the third, how far the power of the crown actually is, or may be, used in accordance with the personal wishes of the king, and how far its exercise is really directed by his ministers; the fourth, how far their action is in turn controlled by Parliament.

\section{Legislative Power}

All legislative power is vested in the King in Parliament; that is, in the king acting in concert with the two houses. Legally, every act requires the royal assent, and, indeed, the 
houses can transact business only during the pleasure of the crown, which summons and prorogues them, and can at any moment dissolve the House of Commons. But it is important to note that by itself, and apart from Parliament, the crown has to-day, within the United Kingdom, no inherent legislative power whatever. This was not always true, for legislation has at times been enacted by the crown alone in the form of ordinances or proclamations; but the practice may be said to have received its death-blow from the famous opinion of Lord Coke, " that the King by his proclamation cannot create any offence which was not an offence before, for then he may alter the law of the land." 1 The English crown has, therefore, no inherent power to make ordinances for completing the laws, such as is possessed by the chief magistrate in France and other continental states. This does not mean that it cannot make regulations for the conduct of affairs by its own servants, by Orders in Council, for example, establishing regulations for the management of the army, or prescribing examinations for entrance to the civil service. These are merely rules such as any private employer might make in his own business, and differ entirely in their nature from ordinances which have the force of law, and are binding quite apart from any contract of employment.

Power to make ordinances which have the force of law and are binding on the whole community is, however, frequently given to the crown ${ }^{2}$ by statute, notably in matters affecting public health, education, etc., and the practice is constantly becoming more and more extensive, until at present the rules made in pursuance of such powers - known as "statutory orders" - are published every year in a

1 Coke's Reports, xii. 76 .

2 Or more strictly to the Crown in Council. 
volume similar in form to that containing the statutes. Some of these orders must be submitted to Parliament, but go into effect unless within a certain time an address to the contrary is passed by one of the houses, while others take effect at once, or after a fixed period, and are laid upon the tables of the houses in order to give formal notice of their adoption.

\section{Executive Power}

The crown is at the head of the executive branch of the central government, and carries out the laws, so far as their execution requires the intervention of any national public authority. In fact all national executive power, whether regulated by statute, or forming strictly a part of the prerogative, that is the ancient inherent royal authority, is exercised in the name of the crown, and by its authority, except when directly conferred by statute upon some officer of the crown, and in this case, as we shall see, it is exercised by that officer as a servant of the crown, and under its direction and control. Legally some of the executive powers are indeed vested in the Crown in Council - that is, in the king acting with his Privy Council - but as the Council has no independent authority, and consists, for practical purposes, of the principal ministers appointed by the crown, even these powers may be said to reside in the crown alone.

All national public officers, except some of the officials of the houses of Parliament, and a few hereditary dignitaries whose duties are purely ceremonial, ${ }^{1}$ are appointed directly by the crown or by the high state officials whom it has itself appointed; and the crown has also the right to remove them, barring a small number whose tenure is during good

1 Such as the hereditary Earl Marshal and Grand Falconer. 
behavior. Of these last by far the most important are the judges, the members of the Council of India, and the Controller and Auditor General, no one of whom has any direct part in the executive government of the kingdom. ${ }^{1}$ Now the right to appoint and remove involves the power to control; and, therefore, it may be said in general that the whole executive machinery of the central government of England is under the direction of the crown.

The crown furthermore authorizes under the sign manual the expenditure of public money in accordance with the appropriations made by Parliament, and then expends the money. It can grant charters of incorporation, with powers not inconsistent with the law of the land, so far as the right to do so has not been limited by statute. The crown grants all pardons, creates all peers, and confers all titles and honors. As head of the Established Church of England it summons Convocation with a license to transact business specified in advance. It virtually appoints the archbishops, bishops and most of the deans and canons, and has in its gift many rectorships and other livings. As head of the army and navy it raises and controls the armed forces of the nation, and makes regulations for their government, subject, of course, to the statutes and to the passage of the Annual Army Act. It represents the empire in all external relations, and in all dealings with foreign powers. It has power to declare war, make peace, and conclude treaties, save that, without the sanction of Parliament, a treaty cannot impose a charge upon the people, or change the law of the land, and it is doubtful how far without

1 On the power of removal from an office held during good behavior, and on the effect of the provision that the three classes of officers mentioned above may be removed upon the address of both houses of Parliament, see Anson, Law and Custom of the Constitution, ii. $213-215$. The references to Anson are to the 3 d ed. of vol. i. (I897); the $2 d$ ed. of vol. ii. (1 896 ). 
that sanction private rights can be sacrificed or territory ceded. ${ }^{1}$

Just as Parliament has often conferred legislative authority upon the crown, so it has conferred executive power in addition to that possessed by virtue of the prerogative. Statutes of this kind have become very common during the last half century in relation to such matters as local government, public health, pauperism, housing of the workingclasses, education, tramways, electric lighting and a host of other things. Even without an express grant of authority, supervisory powers have often been conferred upon the crown by means of appropriations for local purposes which can be applied by the government at its discretion, and hence in accordance with such regulations as it chooses to prescribe. This has been true, for example, of the subsidies in aid of the local police, and of education. By such methods the local authorities, and especially the smaller ones, have been brought under the tutelage of the crown to an extent quite unknown in the past.

\section{Wide Extent of the Royal Power}

All told, the executive authority of the crown is, in the eye of the law, very wide. "It would very much surprise people," as Bagehot remarked in his incisive way, "if they were only told how many things the Queen could do without consulting Parliament. . . Not to mention other things, she could disband the army (by law she cannot engage more than a certain number of men, but she is not obliged to engage any men); she could dismiss all the officers, from the General Commanding-in-Chief downwards; she could

1 Cf. Anson, Law and Custom, ii. 297-299; Dicey, Law of the Constitution, p. 393. Heligoland was ceded to Germany by treaty in 1890 , subject to the assent of Parliament, which was given by $53-54$ Vic., c. 32 . 
dismiss all the sailors too; she could sell off all our ships of war and all our naval stores; she could make a peace by the sacrifice of Cornwall, and begin a war for the conquest of Brittany. She could make every citizen in the United Kingdom, male or female, a peer; she could make every parish in the United Kingdom a 'university '; she could dismiss most of the civil servants; she could pardon all offenders. In a word, the Queen could by prerogative upset all the action of civil government within the government." 1 We might add that the crown could appoint bishops, and in many places clergymen, whose doctrines were repulsive to their flocks; could cause every dog to be muzzled, every pauper to eat leeks, every child in the public elementary schools to study Welsh; and could make all local improvements, such as tramways and electric light, well-nigh impossible.

\section{Powers of the Crown Exercised by Ministers}

Since the accession of the House of Hanover the new powers conferred upon the crown by statute have probably more than made up for the loss to the prerogative of powers which have either been restricted by the same process or become obsolete by disuse. By far the greater part of the prerogative, as it existed at that time, has remained legally vested in the crown, and can be exercised to-day; but it is no longer used in accordance with the personal wishes of the sovereign. By a gradual process his authority has come more and more under the control of his ministers, until it is now almost entirely in the hands of the cabinet, which is responsible to Parliament and through Parliament to the nation. The cabinet is to-day the mainspring of the whole political system, and the clearest method of explaining the

1 English Constitution, 2d ed. (Amer.), Introd., p. 3 r. 
relations of the different branches of the government to each other is to describe in succession their relations with the cabinet.

\section{The King can Do no Wrong}

The doctrine that "the King can do no wrong " had its beginnings as far back as the infancy of Henry III, and by degrees it grew until it became a cardinal principle of the constitution. Legally it means that he cannot be adjudged guilty of wrong-doing, and hence that no proceedings can be brought against him. He cannot be prosecuted criminally, or, without his own consent, sued civilly in tort or in contract in any court in the land. ${ }^{1}$ But clearly if the government is to be one of law, if public officers like private citizens are to be subject to the courts, if the people are to be protected from arbitrary power, the servant who acts on behalf of the crown must be held responsible for illegal conduct from the consequences of which the king himself is free. Hence the principle arose that the king's command is no excuse for a wrongful act, and this is a firmly established maxim of the Common Law in both civil and criminal proceedings. ${ }^{2}$ To prevent royal violations of the law,

1 If a person has a claim against the crown for breach of contract, or because his property is in its possession, he may bring a Petition of Right, and the crown on the advice of the Home Secretary will order the petition indorsed "Let right be done," when the case proceeds like an ordinary suit.

${ }^{2}$ Anson, ii. 4, 5, 42, 43, 278, 279, 476-480. But a servant of the crown is not liable on its contracts, for he has made no contract personally, and he cannot be compelled to carry out the contracts of the crown. Gidley $v$. Lord Palmerston, 3 B. \& B., 284. The rule that the sovereign cannot be sued has been held to prevent a possessory action against a person wrongfully in the possession of land as agent of the crown: Doe d. Legh. v. Roe, 8 M. \& W., 579. It would seem that in such a case the courts might have held that as the king could do no wrong, the wrongful act, and consequently the possession, was not his; in other words, that the agency could not be set up as a defense to the wrongful act. Compare United States $v$. Lee, 106 U. S., I96, where land had been illegally seized by the government of the United States. 
however, it is not enough to hold liable a servant who executes unlawful orders, if the master still has power to commit offenses directly. A further step must be taken by restraining the crown from acting without the mediation of a servant who can be made accountable; and for this reason Edward IV was informed that he could not make an arrest in person. ${ }^{1}$ But, as the kings and queens are not likely to be tempted into personal assaults and trespasses, the principle that they can act only through agents has had little importance from the point of view of their liability at law, although it is a matter of vital consequence in relation to their political responsibility.

The doctrine that the king can do no wrong applies not only to legal offenses, but also to political errors. The principle developed slowly, as a part of the long movement that has brought the royal authority under the control of public opinion; not that the process was altogether conscious, or the steps deliberately planned, but taking constitutional history as a whole, we can see that it tended to a result, and in speaking of this it is natural to use terms implying an intent which the actors did not really possess. To keep the crown from actual violations of law was not always easy, but it was far more difficult to prevent it from using its undoubted prerogatives to carry out an unpopular policy. Parliament could do something in a fitful and intermittent way by refusing supplies or insisting upon the redress of particular grievances, but that alone was not enough to secure harmony between the crown and the other political forces of the day. There could, in the nature of

${ }^{1}$ Coke, Inst. (4th ed.), ii. I86-187. "Hussey Chief Justice reported, that Sir John Markham said to King E. I. that the King could not arrest any man for suspition of Treason, or Felony, as any of his Subjects might, because if the King did wrong, the party could not have his Action." E. I. is a mistake for E. IV. 
things, be no appropriate penalty for royal misgovernment. In the Middle Ages, indeed, a bad king or a weak king might lose his throne or even his life; but in more settled times such things could not take place without a violent convulsion of the whole realm - a truth only too well illustrated by the events of the seventeenth century. An orderly government cannot be founded on the basis of personal rule tempered by revolution. Either the royal power must be exercised at the personal will of the monarch, or else other persons who can be made accountable must take part in his acts of state.

\section{The Nature of Modern Responsibility}

The effort to fasten upon a particular person the actual responsibility for each public act of the crown by compelling some officer to put his approval of it on record, has been superseded by the general principle that the responsibility must always be imputed to a minister. Although ignorant of the matter at the time it occurred, he becomes answerable if he retains his post after it comes to his knowledge; and even though not in office when the act was done, yet if he is appointed in consequence of it, he assumes with the office the responsibility for the act. This happened to Sir Robert Peel in I834. Believing, as every one at that time did believe, that the king had arbitrarily dismissed Lord Melbourne's cabinet, he said, "I should by my acceptance of the office of First Minister become technically, if not morally, responsible for the dissolution of the preceding government, although I had not the remotest concern in it." "The rule is so universal in its operation " that there is not a moment in the king's life, from his accession to his demise, during which there is not some one responsible to

1 Mahon and Cardwell, Memoirs by Sir Robert Peel, ii. 3 I. 
Parliament for his public conduct." 1 A minister is now politically responsible for everything that occurs in his department, whether countersignature or seal is affixed by him or not; and all the ministers are jointly responsible for every highly important political act. A minister whose policy is condemned by Parliament is no longer punished, he resigns; and if the affair involves more than his personal conduct or competence, if it is of such moment that it ought to have engaged the attention of the cabinet, his colleagues resign with him. Thus punitive responsibility has been replaced by political responsibility, and separate has been enlarged to joint responsibility.

\section{The King must Follow the Advice of Ministers}

The ministers, being responsible to Parliament for all the acts of the crown, are obliged to refrain from things that they cannot justify, and to insist upon actions which they regard as necessary. In short, the cabinet must carry out its own policy; and to that policy the crown must submit. The king may, of course, be able to persuade his ministers to abandon a policy of which he does not approve, but if he cannot persuade them, and, backed by a majority in Parliament, they insist upon their views, he must yield. It is commonly said that he must give his ministers his confidence, but it would be more accurate to say that he must follow their advice. With the progress of the parliamentary system this custom has grown more and more settled, the ministers assuming greater control, and the crown yielding more readily, not necessarily from any dread of the consequences, but from the force of habit.

1 Todd, Parl. Government in England, zd ed., i. 266. 
For What Acts Ministers are Responsible

There is one matter in which the crown cannot really be bound by the advice of ministers, and that is in the selection of a premier. It would be obviously improper, not to say absurd, that the king in the selection of a new prime minister should be obliged to follow the opinion of the one who has just resigned in consequence of a change of party in the House of Commons. There is usually one recognized leader of the Opposition, and when that is the case the crown must entrust the formation of the new ministry to him. This was illustrated in I880. Mr. Gladstone had, some years before, retired from the leadership of the Liberals in Parliament, and the Queen, after their success at the general election, sent for Lord Hartington, then leading them in the House of Commons; but she found that Mr. Gladstone, who had really led the party in the country to victory, was the only possible head of a Liberal government. ${ }^{1}$

If the party that has obtained a majority in Parliament has no recognized leader, the crown may entrust the formation of a ministry to any one of its chief men who is willing to undertake the task; or if, as is sometimes the case, the parties have become more or less disintegrated, so that only a coalition ministry can be formed, the crown can send for the head of any one of the various groups. Not to speak of earlier days, when the king had more freedom than at present in the formation of his cabinets, it happened several times in the reign of Queen Victoria that the question who should be prime minister was determined by her personal choice. Such opportunities, however, are likely to be less common in future, for it is altogether probable that a party

1 Cf. Morley, Life of Gladstone, book ii, ch. vii. 
will prefer to choose its own leader rather than to leave the selection to the crown.

At the present day all persons whose offices are considered political are appointed in accordance with the advice of the Prime Minister. This does not mean that the sovereign may not urge his own views, perhaps with success, and on one occasion, at least, the Queen secured, it is said, a place in the cabinet for a former minister whom the incoming premier had either forgotten or meant to leave out. It does mean, however, that if the minister insists upon his advice it must be accepted. In short, the ministers direct the action of the crown in all matters relating to the government. The king's speech on the opening of Parliament is, of course, written by them; and they prepare any answers to addresses that may have a political character. All official letters and reports to the king, and all communications from him, must pass through the hands of one of their number.

Since the king can do no wrong, he can do neither right nor wrong. He must not be praised or blamed for political acts; nor must his ministers make public the fact that any decision on a matter of state was actually made by him. ${ }^{1}$ His name must not be brought into political controversy in any way, or his personal wishes referred to in argument, either within or without Parliament. ${ }^{2}$

${ }^{1}$ Disraeli's opponents were right for criticizing him for letting it be known that it was the Queen who had decided whether to accept his resignation or to dissolve in 1868: Hans. 3 d Ser., cxci. 1705, 1724, 1742, 1788, 1794, I800, I806, I8I I. There was no objection to allowing her to decide if he pleased - that is, he might accept her opinion as his own - but he ought to have assumed in public the sole responsibility for the decision.

${ }^{2}$ In $1876 \mathrm{Mr}$. Lowe in a public speech expressed his belief that the Queen had urged previous ministers in vain to procure for her the title of Empress of India. The matter was brought to the attention of the House of Commons, and he was forced to make an apology, which was somewhat abject, 


\section{Utility of Monarchy}

According to the earlier theory of the constitution the ministers were the counsellors of the king. It was for them to advise and for him to decide. Now the parts are almost reversed and the sovereign is not usually consulted about matters of domestic legislation and policy until the opinion of the cabinet has taken shape. For although he is informed in general terms of what is done at cabinet meetings, and sometimes discusses with a minister the proposed measures relating to his department, yet a matter is commonly talked over and agreed upon by the ministers before it is submitted to him for approval. In this way " the sovereign is brought into contact only with the net results of previous inquiry and deliberation," "and the views of the cabinet are "laid before" him "and before Parliament, as if they were the views of one man." 2 To-day the social and ceremonial functions of the crown attract quite as much interest as ever; but as a political organ it has receded into the background, and occupies public attention far less than it did formerly, while the spread of democracy has made the masses more and more familiar with the actual forces in public life.

On the other hand, the government of England is inconceivable without the parliamentary system, and no one has yet devised a method of working that system without a central figure, powerless, no doubt, but beyond the reach of party strife. Some countries that had no kings have felt constrained to adopt monarchs who might hold a sceptre which they could not wield; and one nation, disliking kings, the Queen through the Prime Minister having denied the truth of his statement. Hans. 3d Ser., ccxxviii. 2023 et seq.; and ccxxix. 52-53.

${ }^{1}$ Gladstone, Gleanings of Past Years, i. 85.

2 Morley, Life of Walpole, p. 155. 
has been forced to set up a president with most of the attributes of royalty except the title. If the English crown is no longer the motive power of the ship of state, it is the spar on which the sail is bent, and as such it is not only a useful but an essential part of the vessel.

To many countries the visible symbol of the state is the flag; but curiously enough there is no British national flag. Different banners are used for different purposes; the king uses the Royal Standard; ships of war carry at the peak the White Ensign; naval reserve vessels fly the Blue Ensign, and merchantmen the Red Ensign; while the troops march, and Parliament meets, under the Union Jack; and all of these are freely displayed on occasions of public rejoicing. Each of the self-governing colonies has, moreover, its own flag, which consists of the Union Jack with some distinctive emblem upon it. The crown is thus the only visible symbol of union in the Empire, and this has undoubtedly had no inconsiderable effect upon the reverence felt for the throne.

Whatever the utility of the crown may be at the present time, there is no doubt of its universal popularity. A generation ago, when the Queen, by her seclusion after the death of Prince Albert, neglected the social functions of the court, a number of people began to have serious doubts on the subject. This was while republican ideals of the earlier type still prevailed, and before men had learned that a republic is essentially a form of government, and not necessarily either better or worse than other forms. The small republican group in England thought the monarchy useless and expensive; but people have now learned that republics are not economical, and that the real cost of maintaining the throne is relatively small. ${ }^{1}$ So that while the benefits

${ }^{1}$ Hans. 4th Ser., xciv. I500. The Civil List of Edward VII was fixed

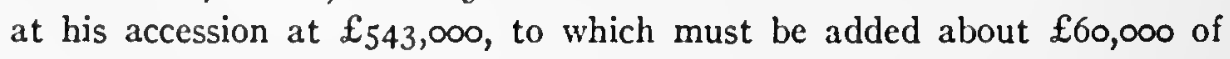


derived from the crown may not be estimated more highly, or admitted more universally than they were at that time, the objections to the monarchy have almost entirely disappeared, and there is no republican sentiment left to-day either in Parliament or the country.

\section{Nature of the Cabinet}

The conventions of the constitution have limited and adjusted the exercise of all legal powers by the regular organs of the state in such a way as to vest the main authority of the central government - the driving and the steering force - in the hands of a body entirely unknown to the law. The members of the cabinet are almost always the holders of public offices created by law; but their possession of those offices by no means determines their activity as members of the cabinet. They have, indeed, two functions. Individually, as officials, they do the executive work of the state and administer its departments; collectively they direct the general policy of the government.

The essential function of the cabinet is to coördinate and guide the political action of the different branches of the government, and thus create a consistent policy. Bagehot called it a hyphen that joins, a buckle that fastens, the executive and legislative together; and in another place he speaks of it as a committee of Parliament chosen to rule the nation. More strictly, it is a committee of the party that has a majority in the House of Commons. The minority is not represented upon it; and in this it differs from every other parliamentary committee. The distinction is so obvious to us to-day, we are so accustomed to govern-

revenues from the Duchy of Lancaster, and also the revenues from the Duchy of Cornwall which go to the heir apparent as Duke of Cornwall. Rep. Com. on Civil List, Com. Papers, rgor, v. 607. 
ment by party wherever popular institutions prevail, that we are apt to forget the importance of the fact.

The cabinet is selected by the party, not directly, but indirectly, yet for that very reason represents it the better. Direct election is apt to mean strife within the party, resulting in a choice that represents the views of one section as opposed to those of another, or else in a compromise on colorless persons; while the existing indirect selection results practically in taking the men, and all the men, who have forced themselves into the front rank of the party and acquired influence in Parliament. The minority is not represented in the cabinet; but the whole of the majority is now habitually represented, all the more prominent leaders from every section of the party being admitted. In its essence, therefore, the cabinet is an informal but permanent caucus of the parliamentary chiefs of the party in power and it must be remembered that the chiefs of the party are all in Parliament. In fact the continental practice whereby ministers are allowed to address the legislature, whether they have seats in it or not, being unknown in England, every member of the cabinet, and indeed of the ministry, must have a seat in one or other House of Parliament.

\section{The Need of Unity and Secrecy in the Cabinet}

Parliamentary government in its present highly developed form requires a very strong cohesion among the members of the majority in the House of Commons, and, therefore, absolute harmony, or the appearance of harmony, among their leaders. Party cohesion, both in the House and in the cabinet, is, indeed, an essential feature of the parliamentary system; ${ }^{1}$ but since men, however united on general princi-

1 This is true in normal times; but early in this war a cabinet of both parties was formed, which for the time suspends the ordinary working of the parliamentary system. 
ples, do not by nature think alike in all things, differences of opinion must constantly arise within the cabinet itself. ${ }^{1}$ Sometimes they are pushed so far that they can be settled only by a division or vote, but this is exceptional, for the object of the members is, if possible, to agree, not to obtain a majority of voices and override the rest. ${ }^{2}$ The work of every cabinet must, therefore, involve a series of compromises and concessions, the more so because the members represent the varying shades of opinion comprised in the party in power.

Men engaged in a common cause who come together for the purpose of reaching an agreement usually succeed, provided their differences of opinion are not made public. But without secrecy harmony of views is well-nigh unattainable; for if the contradictory opinions held by members of the cabinet were once made public it would be impossible afterwards to make the concessions necessary to a compromise without the loss of public reputation for consistency and force of character. Moreover, a knowledge of the initial divergence of views among the ministers would vastly increase the difficulty of rallying the whole party in support of the policy finally adopted, and would offer vulnerable points to the attacks of the Opposition. Secrecy is, therefore, an essential part of the parliamentary system. In fact, by a well-recognized custom, it is highly improper to refer in Parliament, or elsewhere, to what has been said or done at meetings of the cabinet, although reticence must at times place certain members in a very uncomfortable position.

1 One cannot read Mr. Morley's Life of Gladstone without being struck by the frequency of such differences. One feels that in his twenty-five years of life in the cabinet Gladstone must have expended almost as much effort in making his views prevail with his colleagues as in forcing them through Parliament.

${ }^{2}$ In Gladstone's cabinet of $1880-1885$ the practice of counting votes was complained of as an innovation. Morley, Life of Gladstone, iii. 5 . 


\section{The Prime Minister}

At the meetings of the cabinct the Prime Minister as chairman is no doubt merely primus inter pares. His opinion carries peculiar weight with his colleagues mainly by the force it derives from his character, ability, experience and reputation; but apart from cabinet meetings he has an authority that is real, though not always the same or easy to define.

Matters of exceptional importance ought to be brought to his attention before they are discussed in the cabinet; and any differences that may arise between any two ministers, or the departments over which they preside, should be submitted to him for decision, subject, of course, to a possible appeal to the cabinet. He is supposed to exercise a general supervision over all the departments. Nothing of moment that relates to the general policy of the government, or that may affect seriously the efficiency of the service, ought to be transacted without his advice.

Unless the Prime Minister is a peer he represents the cabinet as a whole in the House of Commons, making there any statements of a general nature. The other ministers usually speak only about matters in which they are directly concerned. But the Prime Minister must keep a careful watch on the progress of all government measures; and he is expected to speak not only on all general questions, but on all the most important government bills.

\section{The Cabinet and the Ministry}

The ministry is composed of an inner part that formulates the policy of the government, and an outer part that follows the lines laid down; the inner part, or cabinet, containing the more prominent party leaders, who are also holders 
of the principal offices of state, while the outer part consists of the heads of the less important departments, the parliamentary undersecretaries, the whips and the officers of the royal household. All of these persons are strictly in the ministry, and resign with the cabinet; but the officers of the household have, as such, no political functions, and do not concern us here. By far the greater part of the ministers outside of the cabinet are the parliamentary undersecretaries, who have two distinct sets of duties, one administrative and the other parliamentary. Their administrative duties vary very largely, mainly in accordance with personal considerations. Some of them are really active in their departments, doing work which might fall upon the parliamentary chief, or upon the permanent undersecretary, while others have little or no administrative business; but in any case the real object of their existence is to be found on the parliamentary side. ${ }^{1}$

\section{The Executive Departments}

Although in origin and legal organization the departments of state are very unlike, yet the growth of custom, and the exigencies of parliamentary life, have, for practical purposes, forced almost all of them into something very near one common type. Whatever the legal form of the authority at their head, the actual control is now in nearly every case in the hands of a single responsible minister. Sometimes he is called a secretary of state; sometinies the chairman of a board; sometimes by a peculiar title, like the Chancellor of the Exchequer, who is the minister of finance, or the First Lord of the Admiralty, who is the minister of the navy.

1 It may be noted that the chief secretary of the Lord Licutenant of Ireland is not a parliamentary undersecretary, but the real head of the Irish Office, unless the Viceroy is in the cabinet. 
He is usually assisted by one or more parliamentary subordinates, and is always supported by a corps of permanent non-political officials, who carry on the work of the office.

\section{The Permanent Civil Service}

The history of the permanent civil service would be one of the most instructive chapters in the long story of English constitutional development, but unfortunately it has never been written. The nation has been saved from a bureaucracy, such as prevails over the greater part of Europe, on the one hand, and from the American spoils system on the other, by the sharp distinction between political and nonpolitical officials. The former are trained in Parliament, not in administrative routine. They direct the general policy of the government, or at least they have the power to direct it, are entirely responsible for it, and go out of office with the cabinet; while the non-political officials remain at their posts without regard to party changes, are thoroughly familiar with the whole field of administration, and carry out in detail the policy adopted by the ministers of the day.

If it were not for three or four ministers, such as the Irish Law Officers, who are expected to get themselves elected to Parliament if they can, but whose tenure of their positions does not depend upon their doing so, one might say that the public service is divided into political officers who must sit in Parliament, and non-political officers who must not. The keeping out of politics, and the permanence of tenure must, in the long run, go together; for it is manifest that office can be held regardless of party changes only in case the holders do not take an active part in bringing those changes to pass; and if, on the other hand, they are doomed to lose their places on a defeat at the polls of the party in power, they will certainly do their utmost to avert such a defeat. 
In England the abstinence and the permanence have been attained, and it is noteworthy that they are both secured by the force of opinion hardening into tradition, and not by the sanction of law. Although all officeholders, not directly connected with the conduct of elections, have now a legal right to vote, and are quite at liberty to do so, it is a well-settled principle that those who are non-political that is, all who are not ministers - must not be active in party politics. They must not, for example, work in a party organization, serve on the committee of a candidate for Parliament, canvass in his interest, or make speeches on general politics. All this is so thoroughly recognized that one rarely hears complaints of irregular conduct, or even of actions of a doubtful propriety. In 1874 , when the acts imposing penalties upon their taking an active part at elections were repealed, ${ }^{1}$ it was perfectly well understood that they would not be permitted to go into party politics, and that the government was entitled to make regulations on the subject. ${ }^{2}$ Those regulations are still in force, ${ }^{3}$ and it is only by maintaining them that the civil servants can continue to enjoy both permanence of tenure and the right to vote.

Permanence of tenure in the English civil service, like the abstinence from party politics, is secured by custom, not by law, for the officials with whom we are concerned here are appointed during pleasure, and can legally be dismissed

1 Electioneering by civil servants has been the subject of legislation. An Act of 1710 (9 Anne, c. Io, $\$ 44$ ) rendered liable to fine and dismissal any post-office official who "shall, by Word, Message, or Writing, or in any other Manner whatsoever, endeavour to persuade any Elector to give or dissuade any Elector from giving his Vote for the Choice of any Person . . . to serve in Parliament." Cf. Eaton, Civil Service in Great Britain, p. 85.

${ }^{2}$ In fact in 1874 the bill was amended so as to make this clear. Hans. 3d Ser., ccxix. 797-800.

${ }^{3}$ Cf. Hans. 4th Ser., xvi. I 218 ; liii. II3r. 
at any time for any cause. Now, although the removal, for partisan motives, of officials who would be classed to-day as permanent and non-political, has not been altogether unknown in England, yet it was never a general practice.

The habit of discharging these officials on party grounds never having become established, it was not unnatural that with the growth of the parliamentary system the line between the changing political chiefs and their permanent subordinates should be more and more clearly marked, and this process has gone on until at the present day the dismissal of the latter on political grounds is practically unheard of, either in national or local administration.

\section{Appointment by Competitive Examination}

As early as 1834, examinations for appointment to the civil service began to be used, and these were gradually extended and assumed a competitive form. An order in Council of June $4,1870,{ }^{1}$ which is still the basis of the system of examinations, provides that (except for offices to which the holder is appointed directly by the crown, situations filled by promotion, and positions requiring professional or other peculiar qualifications, where the examinations may be wholly or partly dispensed with) no person shall be employed in any department of the civil service until he has been tested by the Civil Service Commissioners, and reported by them qualified to be admitted on probation. ${ }^{2}$ It provides further that the appointments named in Schedule A, annexed to the Order, must be made by open competitive examination; and this list has been extended from time to time until it covers the greater part

${ }^{1}$ Com. Papers, I870, xix. I, p. vii.

$2 \S \S 2,7$, and Schedule B. Cl. Orders in Council, Aug. I9, I87I, $\S$ I; Sept. I 5,1902 . 
of the positions where the work does not require peculiar qualifications, or is not of a confidential nature, or of a distinctly inferior or manual character like that of attendants, messengers, workmen, etc.

\section{Lay Chief and Expert Subordinate}

Leslie Stephen, I think, remarks somewhere that the characteristic feature of the English system of government is a justice of the peace who is a gentleman, with a clerk who knows the law; and certainly the relationship between the titular holder of a public post, enjoying the honors, and assuming the responsibility, of office, and a subordinate, who, without attracting attention, supplies the technical knowledge and largely directs the conduct of his chief, extends throughout the English government from the Treasury Bench to the borough council.

\section{The Relation between Them}

The theoretical relation between the political chief and his permanent subordinate is a simple one. The political chief furnishes the lay element in the concern. His function is to bring the administration into harmony with the general sense of the community and especially of Parliament. He must keep it in accord with the views of the majority in the House of Commons, and conversely he must defend it when criticized, and protect it against injury by any illconsidered action of the House. He is also a critic charged with the duty of rooting out old abuses, correcting the tendency to red tape and routine, and preventing the department from going to sleep or falling into ruts; and, being at the head, it is for him, after weighing the opinion of the experts, to decide upon the general policy to be pursued. The permanent officials, on the other hand, are to give their ad- 
vice upon the questions that arise, so as to enable the chief to reach a wise conclusion and keep him from falling into mistakes. When he has made his decision they are to carry it out; and they must keep the department running by doing the routine work. In short the chief lays down the general policy, while his subordinates give him the benefit of their advice, and attend to the details.

The smooth working of a system of this kind evidently depends upon the existence of mutual respect and confidence between the minister and the permanent undersecretary. The permanent undersecretary ought to feel, and in fact does feel, a temporary allegiance to his chief, although of a different political party. He gives his advice frankly until the chief has reached a decision, and then he carries that out loyally. The minister on his part seeks the advice of the undersecretary on all questions that arise, making allowance for bias due to preconceived political or personal conviction.

A good minister must be a good administrator, but he must look to results, and not suppose that he knows as much about the technical side of the work as his permanent subordinate. For, as Bagehot quotes Sir George Cornewall Lewis, "It is not the business of a Cabinet Minister to work his department. His business is to see that it is properly worked." 1 If he attempts to go beyond his province, to be dogmatic and to interfere in details, he will cause friction and probably come to grief.

1 The English Constitution, ist ed., p. 240. 


\section{CHAPTER II}

\section{ENGLAND: PARLIAMENT}

\section{The Reform Acts}

THE story of the Reform Act of $\mathrm{r}_{3} 32$ has often been told; how, before its passage, members were elected to the House of Commons by many constituencies which contained very few voters; how in some cases these voters were the owners of land in old chartered boroughs which retained their privileges although they had ceased altogether to be inhabited; and how the act swept away these abuses, together with many local electoral customs, and regulated the franchise on more nearly uniform principles. The conditions it established remained in force until i $867-68$, when other statutes enlarged the franchise and redistributed the seats - a process that was repeated in $1884-85$. These latter acts brought in a very rough approximation to equal electoral districts, and extended the franchise to almost all men who occupied the same premises for a year. But the qualifications were cumbrous, being based upon some relation to land, and including not only the owners but persons technically classed as occupiers, householders and lodgers. The provisions worked injustice in many cases, and allowed men to vote in a number of different constituencies at the same election. There had long been a demand for a revision of the election laws, and a loud cry for the inclusion of women. Finally the war made it clear that soldiers ought to be allowed to vote, which they could not do under laws that made the franchise depend upon actual occupation. 


\section{The Act of 1918}

The ministers at this time belonged to both the great parties, and the reform bill they brought in was not, as is usual, a party measure. It was the result of compromises made in a conference of members from both sides of the House of Commons; and hence, while it introduced universal suffrage based only upon residence, it contained also some provisions slightly favoring trade and education.

\section{The Constitucncies: Boroughs and Counties}

The new act, ${ }^{1}$ which received the royal assent on February 6 , I918, changed not only the franchise but also the constituencies. These still preserve the old distinction between boroughs and counties, the considerable towns being separate constituencies by themselves or cut into electoral divisions; and it may be noted that while a number of boroughs continue to elect two members as an undivided district, all the rest of the constituencies, in boroughs and counties, are single-member districts. The new act rearranged the constituencies afresh with a view to making them as nearly equal in population as possible. ${ }^{2}$ There is in fact only one glaring inequality, that of Ireland, which retains its former number of seats, and is heavily overrepresented pending a measure of home rule that is expected to change radically its representation in Parliament. The number of members in the House was raised by the act from 670 to 709 , and, apart from the university members, 486 of them are allotted to England, 35 to Wales, 7r to Scotland and ror to Ireland.

18 Geo. V, c. 64, and for the constituencies in Ireland, c. 65.

${ }^{2}$ Cr. c. 64 , Schedule 9, and c. 65. 


\section{The Universilies}

Beside the seats allotted to boroughs and counties there are a few reserved for the universities. They have, indeed, been increased by the act. The two members each of $\mathrm{Ox}$ ford, Cambridge and Dublin, the one for London, and the two elected by the four Scotch universities, have been retained; and there have been added, one member for the university of Wales, two for the English provincial universities as a group, another for those in Scotland, and one each for Queen's at Belfast and the National university of Ireland. These members are elected by all holders of a degree from the university, ${ }^{1}$ whether men or women; ${ }^{2}$ and, where more than one member is to be elected by a university constituency, the principle of minority representation is introduced by allowing each voter to cast only one vote, according to the system of preferential, transferable voting. ${ }^{3}$ The House of Lords wanted proportional representation for many other seats, as a protection against popular waves of impulse. To this the Commons would not agree; and finally a compromise was reached whereby, apart from the university constituencies, it was provided ${ }^{4}$ that the crown may appoint commissioners to prepare a scheme for the choice, by proportional representation, of one hundred members in constituencies to be formed by combining existing districts into groups electing from three to five members. The scheme is to take effect if approved by both Houses of Parliament.

$1 \S 2$ except honorary degrees. There are special provisions for the Scotch universities and for that of Dublin.

2 For women see $\S 4$. As in other cases women must be thirty years of age. Women who have qualified for a degree by residence and examination can vote although, as in Oxford and Cambridge, the university does not confer degrees upon them.
$3 \S 20$.
$4 \$ 20(2)$. 


\section{The Parliamentary Franchise for Men}

For boroughs and counties the old qualifications for voters were swept away, and the suffrage extended to all men who for six months prior to the biennial registration reside in the constituency or in an adjoining borough or county. This established complete manhood suffrage for residents; but one of the compromises in the act was the retention, to a certain extent, of a representation of business interests also. It took the form of allowing a man to vote in a constituency where he carries on his business, profession or trade, although not a resident, if he occupies land or premises of the annual value of ten pounds. ${ }^{1}$ He cannot, however, vote in more than one constituency of any kind besides the one in which he resides. ${ }^{2}$ Provision is also made for voting by mail in the case of persons unavoidably absent from the election; and for soldiers, sailors, merchant seamen and fishermen who may, under certain circumstances, vote by proxy. ${ }^{3}$ Moreover, soldiers and sailors in active military service who have attained the age of nineteen may vote, although the age for other men is twenty-one. ${ }^{4}$

\section{The Local Franchise for Men}

The right to vote for local governing bodies has always differed from the parliamentary franchise, and has not been the same for all local bodies. The act sought to simplify this also; but objection was raised to a complete extension of manhood suffrage to local elections, on the ground that the

18 Geo. $V$, c. $64, \S$ I.

${ }^{2} I d ., \S 8$. This includes the universities. The act also provides that at a general election the voting shall take place everywhere on the same day ( $\$ 21$ ), thereby abolishing a practice that was alleged to have been abused for party purposes.
I Id., \& 23.
- $I d, \$ 5$. 
costs of local government fall on the rate payers alone; and that, as the rates are assessed only on the occupiers of land and buildings, they ought to be the voters. The act provided, therefore, that the local franchise shall be limited to occupiers, as owners or tenants, of any land or premises within the area. ${ }^{1}$ The persons excluded are mainly servants and bachelors living in the parental home; and, on the other hand, men are included, as before, who reside outside the area but carry on their occupation on their own account within it.

\section{The Franchise for Women}

The right of women to vote which had not been acquired by violence, was achieved by women's work in the war. There was a general desire to extend the franchise to them, but it was not thought wise to create an electorate preponderately feminine, which would be the result of extending the franchise to women on the same terms as to men. To avoid this their right to vote was limited in two ways, by age and by requiring them to be occupiers. The act provides, ${ }^{2}$ therefore, that a woman shall be entitled to be a parliamentary elector if she is thirty years old, and occupies any dwelling, or any other land or premises of the annual value of five pounds, or is the wife of such an occupier. In local government elections she is entitled to vote as a man would be if she is an occupier in her own right; she is also entitled to vote if thirty years old and the wife of a man occupying premises in which they both reside. Thus a woman cannot vote for Parliament unless she is thirty years old and an occupier in her own right or that of her husband; but she can vote in local matters if twenty-one, provided she is an

1 Except furnished lodgings. 8 Geo. V, c. $64, \S_{3}$.

${ }^{2} I d ., \$ 4$. 
occupier in her own right, the reason being that in certain cases she already had this last privilege.

The act has doubled the parliamentary electorate, increasing the voters from eight millions to sixteen millions, chiefly by the addition of women. What the effect upon politics will be no one yet knows, and it is useless to attempt. to predict. That it will bring about some change in the method of electioneering and the proceedings of candidates there can be little doubt.

\section{Candidates and Elections}

In fact the act itself contains provisions that touch upon the position of candidates. An enlarged electorate would naturally involve increased expense, especially since the laws against corrupt practices limited the amount a candidate might spend to a fixed sum for each registered voter in the constituency. This is reduced for each voter to seven pence in a county and five pence in a borough, in addition to certain personal expenses and fees of the candidate ${ }^{1}-\mathrm{a}$ reduction not far from proportionate to the increase of the electorate. It leaves the total expenditure of the candidate nearly what it was before; but the act also provides that the charges of the returning officer for the erection of polling booths and the attendants thereat, which were formerly paid by the candidates, shall be defrayed by the public treasury. ${ }^{2}$ Fearing that the reduction in cost might multiply needlessly futile candidates the act obliges each of them to deposit one hundred and fifty pounds to be forfeited if he fails to receive one-eighth of the votes cast. ${ }^{3}$ It may be observed that the restrictions upon the cost of

18 Geo. V, c. 64 , Schedule 4 .

${ }^{2} I d ., \S 29$.

$3 I d ., \S \S 26,27$. 
elections do not touch the practice known as nursing constituencies, that is, seeking the favor of the voters by spending money on public objects well in advance of the election.

In rgr I the House of Commons, by inserting an appropriation in its vote of supply introduced the payment of its members. In the same year a statute reduced the term of Parliament from seven to five years. ${ }^{1}$

\section{The Commons' House}

Even the arrangement of seats in the House is not without its bearing upon political life; and although a small matter, it affords another illustration of the principle that an institution which, instead of being deliberately planned, is evolved slowly, will develop in harmony with its environment, or force its environment into harmony with itself. The front bench at the upper end of the aisle, close at the right hand of the Speaker, is called the Treasury Bench, and is reserved for the ministers; the corresponding bench on the other side being occupied by the former ministers of the party now in Opposition. Behind these two benches sit for the most part men whose fidelity to their respective parties is undoubted, members whose allegiance is less absolute generally preferring seats below the gangway on either side.

\section{The Speaker}

The Speaker of the House of Commons occupies a highly honorable and important position, but in some respects the custom of his election is peculiar. If only one person is nominated, he is called to the chair without a vote. If more than one, they are voted upon successively, a majority being required for election. ${ }^{2}$ The proposer and seconder are always private members, for it is considered more fitting that

$$
1 \text { I-2 Geo. V, c. I3, § 7. } 2 \text { May, P. I5I. }
$$


the ministers should not be prominent in the matter. ${ }^{1}$ The Speaker is, however, always selected by the government of the day, and a new Speaker is always taken from the ranks of the party in power. Sometimes the election is not uncontested, and this happened when Mr. Gully was chosen in 1895 . But although the Speaker may have been opposed when first chosen, and although he is elected only for the duration of the Parliament, it has now become the invariable habit to reëlect him so long as he is willing to serve. The Speaker is purely a presiding officer. He has nothing to do with appointing any committees, or guiding the House in its work. He is not a leader but an umpire, otherwise he could not remain in the chair through changes of party. As an umpire, however, his powers are very great, and in some cases under the modern changes in the standing orders they are autocratic. Moreover, from his decision on those matters, or on any points of order, there is no appeal. ${ }^{2}$ The House can suspend or change its own rules by a simple majority vote, but it cannot in a concrete case override the Speaker's construction of them. ${ }^{3}$

\section{The Committees}

No great representative assembly at the present day can do all its work in full meeting. It has neither the time, the patience nor the knowledge required. Its sittings ought not

1 Cf. ibid., p. I50, note 3 .

2 But the Speaker himself may submit a question to the judgment of the House. May, p. 33r.

3 The action of the Speaker can be brought before the House only by a motion made at another time after due notice, but this is, of course, almost useless for the purpose of reversing the ruling complained of: Hans. 3 d Ser., cclviii. 10, 14. On the occasion when Speaker Brand made this ruling he intimated that a member making on the spot a motion to disagree with it would be guilty of disregarding the authority of the chair, and liable to suspension under the standing orders. Ibid., p. 9 . 
to be frittered away in discussing proposals that have no chance of success; while measures that are to be brought before the whole body ought to be threshed out beforehand, their provisions carefully weighed and put into precise language, objections, if possible, met by concession and compromise, or brought to a sharp difference of principle. In short, they ought to be put into such a shape that the assembly is only called upon to decide a small number of perfectly definite questions. To enable it to do so intelligently it may be necessary also to collect information about doubtful facts. Modern assemblies have sought to accomplish these results mainly by committees of some kind; and in England where the parliamentary form of government has reached a higher development than anywhere else, the chief instrument for the purpose is that informal joint committee of the houses, known as the cabinet. But unless Parliament were to be very nearly reduced to the rôle of criticizing the ministers, and answering yes or no to a series of questions propounded by them, it must do a part of its work through other committees.

\section{The Committee of the Whole}

The most important committee, the Committee of the Whole, is not in this sense a committee at all. It is simply the House itself acting under special forms of procedure; the chief differences being that the chairman of committees presides, and that the rule of the House forbidding a member to speak more than once on the same question does not apply. But the fact that a member can speak more than once makes it a real convenience for the purpose for which it is chiefly used, that is, the consideration of measures in detail, such as the discussion and amendment of the separate clauses of a bill, or the debates upon different items of ap- 
propriations. The Committee of the Whole has had a long history. ${ }^{1}$ It is called by different names according to the subject matter with which it deals. For ordinary bills it is called simply the Committee of the Whole. When engaged upon appropriations it is called Committee of the Whole on Supply, or in common parlance the Committee of Supply. When providing money to meet the appropriations it is called the Committee of Ways and Means.

\section{Select Committees}

Of the real committees the most numerous are the select committees whose normal size is fifteen members. They are usually appointed, in part at least, by the Committee of Selection, which is chosen by the House at the beginning of each session, ${ }^{2}$ but whose members are in fact designated by an understanding between the leaders of the two great parties in the house. The object is to secure an impartial body for the selection of other committees of all kinds, and so far is this object attained that in the memoir of Sir John Mowbray who was its chairman continuously for thirtytwo years, we are told that divisions in the committee are rare, and never on party lines. ${ }^{3}$

The sessional select committees are the Committee on Public Accounts, ${ }^{4}$ which goes through the report of the Auditor and Comptroller General, considers in detail objections to the legality of any expenditures by the public departments, examines witnesses thereon, and reports to the House; the Committee on Public Petitions, appointed to inspect the numerous petitions presented to the House; ${ }^{5}$

${ }^{1}$ Redlich, Recht und Technik des Englischen Parliamentarismus, pp. 474478 .

2 Standing Orders (relative to private business), p. 98.

3 Seventy Years at Westminster, pp. 267 et seq.

4 S. O., p. 75.

s S. O., pp. 76-80. 
and the Committee on the Kitchen and Refreshment Rooms which has importance for the members of the House, though not for the general public.

The other select committees are created to consider some special matter that is referred to them, either a bill, or a subject upon which the House wishes to institute an inquiry. ${ }^{1}$ In either case the chief object of the committee is to obtain and sift information. ${ }^{2}$ Select committees are the organs, and the only organs, of the House for collecting evidence and cxamining witnesses; and hence they are commonly given power to send for persons, papers and records. They summon before them people whose testimony they wish to obtain. They keep minutes, not only of their own proceedings, but also of all evidence taken before them; and these, together with the report of their conclusions, are laid before the House ${ }^{3}$ and published among the parliamentary papers of the session. The fact that men with all shades of opinions sit upon these committees, and have an opportunity to examine the witnesses, lifts their reports, and still more the evidence they collect, above the plane of mere party documents, and gives them a far greater permanent value.

1 The question of ten arises whether inquiry shall be conducted by a committce of the house, or by a commission appointed by the government. When the matter is distinctly political a committee of the house is the proper organ; but when the judgment of outside experts is needed the other alternative is obviously preferable, several members of Parliament being often included in such cases. Naturally enough, the ministry and the members chiefly interested in pushing an inquiry do not always agree about the matter. One instance of a dispute on this point was that in relation to the grievances of post-office employees. Another famous example occurred upon the charges made by The Times against Parnell in connection with the forged Pigott Letters.

2 May, pp. 469-470.

3. S. O., pp. 59-61, 63 . 


\section{Standing or Grand Committees}

As the pressure for time in the House of Commons grew more intense, select committees that collected information were not enough. Something was needed that would save debate in the House, and for this purpose resolutions were adopted on Dec. I, I882, for setting up two large committees on bills relating to law and to trade, whose deliberations should take the place of debate in the Committee of the Whole. As distinguished from select committees, which expire when they have made a report upon the special matters committed to their charge, they were made standing bodies, lasting throughout the session. They consist of not less than sixty nor more than eighty members of the House, appointed by the Committee of Selection, which has power to discharge members and substitute others during the course of the session. In order to secure the presence of persons who may throw light on any particular bill, the same committee can also appoint not more than fifteen additional members for the consideration of that bill.

With a view to enlarging the legislative capacity of Parliament a select committee on Procedure in the House of Commons reported on May 25, 1906, in favor of increasing the number of standing committees from two to four, and making the reference of bills to them the normal, instead of an exceptional, procedure. The plan was adopted in the following year, and hence all bills, except money bills and bills for confirming provisional orders, are now referred to one of the standing committees, unless the House otherwise order on a motion to be decided without amendment or debate. The bills are distributed among the committees by the Speaker. 
The object of the change was to give a better chance of enactment for measures which there is not time to debate in Committee of the Whole; and the provision that the House may vote not to send a bill to a standing committee was designed chiefly for the great party measures of the government which must always be debated in the House itself.

\section{Procedure on Public Bills}

A public bill, when presented, is read a first time, and in the case of government bills, this is an occasion for a speech explaining its object, and a debate.

The next step, and, except on great party measures, the first occasion for a debate, is the second reading. This is the proper stage for a discussion of the general principles of the bill, not of its details, and amendments to the several clauses are not in order.

After the second reading a bill, until ${ }_{9007}$, went normally to the Committee of the Whole, with or without instructions, and now it goes there if the House so decides. When the order of the day for the Committee of the Whole is reached the Speaker leaves the chair, and the House goes into committee without question put. ${ }^{1}$ This is the stage for consideration of the bill in detail, and the clauses are taken up one after another, the amendments to each clause being disposed of in their order. Then new clauses may be proposed, and finally the bill is reported back to the House.

Normally a bill goes either to the Committee of the Whole or to a standing committee, but after it has been read a second time a motion may be made to refer it to a select committee. Such a reference simply adds a step to the journey of the bill, for when reported it goes to a standing committee or to the Committee of the Whole. A standing committee,

${ }^{2}$ S. O., p. 5I. Adopted in 1888. 
on the other hand, is, as already explained, a substitute for the Committee of the Whole. It deals with the bill in precisely the same way, reporting it back to the House amended or unchanged.

When a bill has been reported from the Committee of the Whole with amendments, ${ }^{1}$ and when it has been reported from a standing committee whether amended or not, ${ }^{2}$ it is considered by the House in detail, upon what is known as the report stage. The object is to give the House an opportunity to review the work done in committee, and see whether it wishes to maintain the amendments there adopted.

The next, and now the last, stage of a bill in the House of Commons is the third reading. Like the second reading, this raises only the question whether or not the House approves of the measure as a whole. Verbal amendments alone are in order, and any substantial alteration can be brought about only by moving to recommit.

Leaving out of account the first reading, which rarely involves a real debate, the ordinary course of a public bill through the House of Commons gives, therefore, an opportunity for two debates upon its general merits, and between them two discussions of its details, or one debate upon the details if that one results in no changes, or if the bill has been referred to a standing committee.

\section{Procedure on Money Bills}

The procedure in the case of financial measures differs in important respects from that followed in passing other bills. With some exceptions all the national revenues are first paid into the Consolidated Fund, and then drawn out of it to meet the expenditures of the government. The financial

$$
{ }^{1} \text { S. O., p. 39. } \quad 2 \text { S. O., p. } 50 .
$$


work of Parliament turns, therefore, upon the processes of getting money into and out of that fund. The second process comes first in the order of parliamentary business, and its nature is fixed by two standing orders, which date from the early years of the eighteenth century. One of them, adopted in I707, provides that the House will not proceed upon any petition or motion for granting money but in Committee of the Whole House; ${ }^{1}$ the other, that it will not receive any petition, or proceed upon any motion, for a grant or charge upon the public revenue unless recommended from the crown. ${ }^{2}$

This last rule, first adopted by a resolution in 1706 , and made a standing order in $1713,{ }^{3}$ was designed to prevent improvident expenditure on private initiative. It has proved not only an invaluable protection to the Treasury, but a bulwark for the authority of the ministry. ${ }^{4}$ Its importance has been so well recognized that it has been embodied in the fundamental laws of the self-governing colonies; ${ }^{5}$ while some foreign countries, like France and Italy, that have copied the forms of parliamentary government, without

1 S. O., p. 67.

2 S.O., p. 66. May (p. 527) points out that these two rules, together with S. O.. p, 68 , adopted in 1715 , that the House will receive no petition for compounding a revenue debt due to the crown without a certificate from the proper officer stating the facts, were for more than a century the only standing orders of the House.

3 Todd, Parl. Government in England, 2d ed., i. 691.

- As an illustration of the fact that the rise of the authority exerted by ministers over Parliament was contemporary with the loss by the king of personal legislative power, Todd (ii. 390) remarks that this rule was first adopted in 1706 , and the last royal veto was given in 1707 .

s E.g., British North Amer. Act, $\S 54$. Commonwealth of Australia Constitution Act, $\$ 56$.

After the government of India was transferred from the East India Company to the crown, in 1856 , the rule was extended to motions for a charge upon the Indian revenue. S. O., p. 70. 
always perceiving the foundation on which they rest, have suffered not a little from its absence.

As grants of money can be taken up only in Committee of the Whole, and only on the recommendation of the crown, - that is, of a minister - the House resolves itself, early in the session, into Committee of the Whole on Supply, to consider the estimates submitted by the government. ${ }^{1}$

Certain fixed charges, such as the interest on the national debt, the royal civil list, and the salaries of the judges, are payable by statute out of the Consolidated Fund, and hence do not require an annual vote of Parliament, or come before the Committeee of Supply. The estimates for the rest of the expenditures for the coming year, known as the supply services, are divided into three parts, relating to the army, the navy, and the civil services. The last of the three is divided into classes, and all of them are divided into grants or votes, which are in turn subdivided into subheads and items. Each grant is the subject of a separate vote in Committee of Supply, and amendments may be moved to omit or reduce any item therein.

But the committee merely passes and reports to the House resolutions in favor of those grants, and the money cannot be paid out of the Consolidated Fund without the authority of a statute. The next step is taken in the Committee of the Whole on Ways and Means, where on the motion of a minister another resolution is passed, that to make good the supply already voted, the sum required be granted out of the Consolidated Fund. This in turn must be reported to and confirmed by the House. ${ }^{2}$ A bill called a Consolidated

${ }^{1}$ S. O., p. I4 provides that the Committees of Supply and Ways and Means shall be set up as soon as the address in reply to the king's speech bas been agreed to.

2 On the procedure in the Committee of Ways and Means, and on Report from Committee of Supply and of Ways and Means, see May, pp. 588 et seq. 
Fund Bill is then brought in to give effect to the resolution. The bill, with the separate grants, annexed in a schedule, goes through the ordinary stages; but the time spent upon it is short, because its only object being to authorize the issue of money to cover the supply already voted, no amendment can be moved to reduce the amount, or change the destination, of the grants. ${ }^{1}$

\section{The Budget}

So much for the process of getting money out of the Consolidated Fund. That of getting money into the fund goes on at the same time, but independently. It is usually early in April that the Chancellor introduces his budget in the Committee of Ways and Means. In an elaborate speech he reviews the finances of the past year, comparing the results with the estimates, and dealing with the state of trade and the national debt. He then refers to the estimates already submitted, and coming to the gist of his speech, and the part of it that is awaited with curiosity, he explains how he proposes to raise the revenue required to meet the expenditures. The budget speech of the Chancellor of the Exchequer is followed by a general discussion of the questions he has raised; and either at once, or on subsequent days, by debates and votes upon the resolutions he has brought in. The resolutions when adopted are reported to the House for ratification, but as in the case of supply, they have no legal effect until enacted in the form of a statute.

\section{The Public Accounts}

The whole initiative, as regards both revenue and expenditure, lies with the government alone. The House has merely power to reject or reduce the amounts asked for,

1 May, p. 526; Ilbert, Manual, § 245, note. 
and it uses that power very little. Financially; its work is rather supervision than direction; and its real usefulness consists in securing publicity and criticism rather than in controlling expenditure. It is the tribunal where at the opening of the financial year the ministers must explain and justify every detail of their fiscal policy, and where at its close they must render an account of their stewardship. This last duty is highly important. The House receives every year reports of the administration of the finances from three independent bodies, or, to be more accurate, it receives two distinct sets of accounts and one report. As soon as possible after the close of the financial year, the Treasury submits the Finance Accounts, which cover all receipts paid into, and all issues out of, the Consolidated Fund, giving the sources from which the revenue was derived and the purpose for which the issues were made.

Meanwhile the Comptroller and Auditor General - who holds his office during good behavior, with a salary paid by statute directly out of the Consolidated Fund, and who considers himself in no sense a servant of the Treasury, but an officer responsible to the House of Commons ${ }^{1}-\mathrm{ex}$ amines the accounts of the several departments. This is a matter requiring much time, and it is not until the opening of the next regular session that he presents what are known as the Appropriation Accounts, ${ }^{2}$ covering in great detail the actual expenditures in all the supply services, with his reports and comments thereon. ${ }^{3}$

1 See his evidence before the Com. on Nat. Expend., Com. Papers, 1902, vii. $15,2 \leq .764-769,83$ I.

2 Thus the Parliamentary Papers for rgo3 contain the Finance Accounts for the financial year ending $\mathbf{M}$ arch $3 \mathrm{I}$, Ig03, and the far more elaborate Appropriation Accounts for the year ending March 3I, I902.

${ }^{3}$ He presents also separate accounts of the Consolidated Fund services, and other matters, with reports upon them. 
His accounts and reports are referred to the Committee of Public Accounts, which consists of eleven members of the House chosen at the beginning of the session, ${ }^{1}$ and includes the Financial Secretary of the Treasury, some one who has held a similar office under the opposite party, and other men interested in the subject. It inspects the accounts and the Comptroller and Auditor General's notes of the reason why more or less than the estimate was spent on each item. It inquires into the items that need further explanation. examining for the purpose the auditing officers of the departments, and other persons; and it makes to the House a report or series of reports, which refer in detail to the cases where an excess grant must be made by Parliament, or a transfer between grants in the military departments must be approved.

\section{Framing Legislatice Questions}

For the purpose of collective action every body of men is in the plight of M. Noirtier de Villefort in "Monte Cristo," who was completely paralyzed except for his eyes. Like him it has only a single faculty, that of saying Yes or No. Individually the members may express the most inrolved opinions, the most complex and divergent sentiments, but when it comes to roting, the body can rote only Yes or No. Some one makes a motion, some one else mores an amendment, perhaps other amendments are superimposed, but on each amendment in turn. and finally on the main question. the body simply rotes for or against.

1 S. O., p. 75. For a brief history of the system of audit, and the laying of accounts before Parliament, see the memorandum by Lord Welby. Rep. Com. on Nat. Expend., Com. Papers, 1902, vii. 15, App. I3. See also the description by Hatschek, in his Englisches Staatsrecht (pp 495-500), of the introduction into England of double entry and the French system of keeping the national accounts. 
Obviously, therefore, it is of vital importance to know who has power to ask the question. In small bodies that have limited functions and an abundance of time, the members are free to propose any questions they please; but in large assemblies, all of whose proceedings are of necessity slower, this freedom is curtailed by lack of time, especially if the range of activities is wide. Hence the legislatures of all great states have been constrained to adopt some process for restricting or sifting the proposals or bills of their members. The most common device is that of referring the bills to committees, which can practically eliminate those that have no serious chance of success, and can amend others, putting them into a more acceptable form. In such cases the committees enjoy, if not the exclusive privilege of proposing questions to the legislature, at least the primary right of framing the questions that are to be submitted, and this gives them a momentous power.

The cabinet has been said to be a committee, and the most important committee of the House of Commons; but it is really far more. Unlike an ordinary committee, it does not have the bills of members referred to it. On the contrary it has the sole right to initiate, as well as to frame, the measures it submits to the House; and these comprise, in fact, almost all the important bills that are enacted. By far the greater part of legislation originates, therefore, exclusively with the ministers. The system of a responsible ministry has obstructed the growth of committees; because, in the case of government measures, the chief function of such committees, that of sifting bills and putting them into proper shape, is performed by the cabinet itself; and also because, as will be shown hereafter, the authority of the cabinet would be weakened if other bodies, not necessarily 
in accord with it, had power to modify its proposals. In this connection it may be observed that in the domain of bills for private and local objects, to which the responsibility of the cabinet does not extend, there has developed a most elaborate and complete set of committees, to which all such bills are referred.

\section{Private Members' Bills}

Private members are free to bring their public bills before the House, unfettered by any committee, provided they can find a chance to do so in the extremely meagre allowance of time at their disposal. In short the Commons have solved the question of time by giving most of it to the government, and leaving the private members to scramble for the rest by drawing lots for it.

A private member must be very fortunate in the ballot, or he must have a number of friends interested in the same bill, to get it started with any prospect of success; and even then there is scarcely a hope of carrying it through if a single member opposes it persistently at every point. Only ten or fifteen such bills are enacted a year, and of these only a couple provoke enough difference of opinion to lead to a division during their course in the House. ${ }^{1}$

All the sittings not reserved for private members are at the disposal of the government, which can arrange the order of business as it pleases. ${ }^{2}$

1 Although the time at the disposal of private members has not changed much of late years, the number of these bills enacted, and especially of those enacted against opposition, has diminished sensibly. In the decade from I 878 to 1887 about twenty-three such bills were passed a year, and on four or five of these divisions took place.

${ }^{2}$ S. O., p. 5. 


\section{The Cabinet's Control of Legislation}

The responsibility of the ministers for the legislation they propose is a comparatively recent matter. ${ }^{1}$ By the middle of the nineteenth century it had begun to be recognized, and at the present day, the ministers would treat the rejection of any of their important measures as equivalent to a vote of want of confidence. ${ }^{2}$ Moreover, the government is responsible not only for introducing a bill, but also for failing to do so. At a meeting in the autumn the cabinet decides upon the measures it intends to bring forward, and announces them in the king's speech at the opening of the session. Amendments to the address in reply are moved expressing regret that His Majesty has not referred to some measure that is desired, and if such an amendment were carried it would almost certainly cause the downfall of the ministry.

Following upon the responsibility for the introduction and passage of all important measures has come an increasing control by the ministers over the details of their measures. It was formerly maintained that the House could exercise a great deal of freedom in amending bills, without implying a loss of general confidence in the cabinet. ${ }^{3}$ But of late amendments carried against the opposition of the Treasury Bench have been extremely rare. This does not mean that the debates on the details of bills are fruitless. On the contrary, it often happens that the discussion exposes defects of which the government was not aware,

${ }^{1}$ Cf. Todd, Parl. Government in England, ii. 368 . Ilbert, Legislative Methods and Forms, pp. 82, 216.

2 The only cases where a government bill has been rejected by the House of Commons for more than a score of years are those of the Home Rule Bill in 1886, on which the cabinet dissolved Parliament, and an insignificant bill on church buildings in the Isle of Man, which was defeated in a thin House in 1897 .

- Cf. Todd, Parl. Government in England, ii. 370-372. 
or reveals an unsuspected but widespread hostility to some provision; and when this happens the minister in charge of the bill often declares that he will accept an amendment, or undertakes to prepare a clause to meet the objection which has been pointed out.' But it does mean that the changes in their bills are made by the ministers themselves after hearing the debate, and that an amendment, even of small consequence, can seldom be carried without their consent. This is the natural outcome of the principle that the cabinet is completely responsible for the principal public measures, and hence must be able to control all their provisions so long as it remains in office.

\section{The Commons' Control over Administration}

If the relations between the cabinet and the House of Commons in legislative matters have changed, their relations in executive matters have been modified also. If the cabinet to-day legislates with the advice and consent of the House, it administers subject to its constant supervision and criticism. In both cases the relation is fundamentally the same. In both the English system seems to be approximating more and more to a condition where the cabinet initiates everything, frames its own policy, submits that policy to a searching criticism in the House, and adopts such suggestions as it deems best; but where the House, after all this has been done, must accept the acts and pro-

1 The minister often says that he will consider whether he can meet the views that have been expressed; and then on the report stage he brings up a compromise clause. An interesting example of this occurred on July 23, I9o6, when the Opposition complained that sufficient time had not been given for debating the educational council for Wales, the provisions proposed having been profoundly changed since it had been last before the House. The government replied that the changes had been made to meet objections raised by the Opposition itself. Hans. 4th Ser., clxi. 74I et seq. 
posals of the government as they stand, or pass a vote of censure and take the chances of a change of ministry or a dissolution.

The House of Commons does not often pass votes asking for executive action in the future, but its members criticize the conduct of the government in the past freely and constantly. The opportunities for doing so are, indeed, manifold. There is first the address in answer to the king's speech at the opening of the session; then the questions day by day give a chance, if not for direct criticism, at least for calling the ministers to account; then there are the motions to adjourn; the private members' motions; the debates on going into the Committees of Supply and Ways and Means; the discussions in the Committee of Supply itself; the debates on the Consolidated Fund Resolutions, on the Appropriation Bill, and on the Budget; and, finally, the formal motions of want of confidence.

\section{Criticism and Censure}

But first it is important to distinguish between individual criticism by members, and collective censure by vote of the House. The former, whether coming from the seats behind the Treasury Bench, or from the opposite side of the floor, is in the nature of a caution to the ministers, an expression of personal opinion that is likely to find more or less of an echo outside of Parliament. It does not in itself imperil the position of the government at the moment, although the errors of the ministers pointed out in this way go into the great balance of account on which the nation renders its verdict at the next general election. But a collective censure by vote of the House may mean immediate resignation. Now the system of a responsible ministry implies the alternation in power of two parties holding different views upon 
the questions of the day. If it does not imply this; if the fall of one cabinet is followed by the appointment of another with a similar policy; then public life will revolve about the personal ambitions and intrigues of leading politicians, - a condition that has caused much of the discredit now attached to the parliamentary system in some continental states. But if a change of ministry involves the transfer of power to an Opposition with quite a different programme, it is clear that the change ought not to take place until the nation has declared, either at the polls, or through its representatives in the House of Commons, that it wishes that result. The ministers ought, therefore, to stand or fall upon their general policy, upon their whole record, or upon some one question that in permanent consequence outweighs everything else, not upon a particular act of secondary importance. Moreover the judgment ought to be given after mature deliberation, not in the heat of a debate upon some political blunder brought suddenly to the notice of the House. The Opposition can at any time claim to move a vote of want of confidence, and within reasonable limits the cabinet will always assign a day for the purpose. But this is quite a different matter from the criticism of particular acts. Whatever the precise form of any motion may be, if the the object is to turn the ministry out, every member goes into one or the other lobby, according to his desire that the cabinet shall stand or fall. The judgment of the House is passed not upon any one act or question of policy, but distinctly upon the record of the ministry as a whole; and a defeat must be immediately followed by resignation or dissolution.

From a survey of the various methods by which the ministers can be called to account in the House of Commons, it is clear that the opportunities to air grievances, to sug- 
gest reforms, and to criticize the government for both large matters and small, for their general policy and their least administrative acts, are many and constant. For the object they serve, that of turning a searchlight upon the government, and keeping the public informed of its conduct, they are abundant. On the other hand, the opportunities to pass judgment by a definite vote upon particular acts of the ministers, as distinguished from their conduct as a whole, have diminished very much, and there is a marked tendency to make a definite expression of opinion on such matters by vote of the House more and more difficult. Such a tendency is entirely in accord with the true principle of parliamentary government. There ought to be the fullest opportunity for criticism; but the cabinet must be free not only to frame its own policy, but also to carry that policy out, and it ought not to be shackled, or thrust out, so long as its conduct of affairs is on the whole satisfactory to the nation.

\section{Parliament the Inquest of the Nation}

The system of a responsible ministry can develop in a normal and healthy way only in case the legislative body is divided into two parties, and under those conditions it is the inevitable consequence of the system that Parliament cannot support the cabinet on one question and oppose it on another. The programme of the ministers must be accepted or rejected as a whole, and hence the power of initiative, both legislative and executive, must rest entirely with them. This is clearly the tendency in Parliament at the present day. ${ }^{1}$ The House of Commons is finding more and

1 Redlich ends his book on the procedure of the House of Commons with the remark (p. 800), that the rules of a legislative body are the political manometer, which measures the strain of forces in the parliamentary machine, and thereby in the whole organism of the state. 
more difficulty in passing any effective vote, except a vote of censure. It tends to lose all powers except the power to criticize and the power to sentence to death. Parliament has been called the great inquest of the nation, and for that purpose its functions have of late been rather enlarged than impaired. Nor are the inquisitors confined to any one section of the House, for while that part is played chiefly by the Opposition, the government often receives a caution from its own supporters also. If the parliamentary system has made the cabinet of the day autocratic, it is an autocracy exerted with the utmost publicity, under a constant fire of criticism; and tempered by the force of public opinion, the risk of a vote of want of confidence, and the prospects of the next election.

\section{Private Bill Legislation}

If the direction of important legislation of a public character lies almost altogether in the hands of the ministers, special laws affecting private or local interests are not less completely outside of their province. Private bill procedure has both a legislative and a judicial aspect. The final aim being the passage of an act, a private bill goes through all the stages of a public bill, and the records of its progress appear in the journals of the House. But the procedure is also regarded as a controversy between the promoters and opponents of the measure, and this involves an additional process of a judicial character.

The committee stage of the bill, for the consideration of its provisions in detail, is devolved upon a private bill committee. Here takes place the judicial process, or trial of the controversy between conflicting interests, which presents the peculiar feature of the English procedure. All opposed private bills are referred under the rules to the Committee 
of Selection, which divides them into groups and refers each group to a committee, consisting of a chairman and three members not locally or otherwise interested, whom it appoints for the purpose. ${ }^{1}$

The hearing of the parties before the committee follows the pattern of a trial in a court of law, even to the standing of the counsel employed. The proceedings are strictly judicial in form, the barristers examining and cross-examining the witnesses and making the arguments in the ordinary way. Moreover, if either party has vexatiously subjected the other to expense, the committee can award costs like a court of law, and this is occasionally done. ${ }^{2}$

The English system of private bill legislation has its defects, but they are far more than outweighed by its merits. The curse of most representative bodies at the present day is the tendency of the members to urge the interests of their localities or their constituents. It is this more than anything else that has brought legislatures into discredit, and has made them appear to be concerned with a tangled skein of private interests rather than with the public welfare. ${ }^{3}$ It is this that makes possible the American boss, who draws his resources from his profession of private bill broker. Now the very essence of the English system lies in the fact that it tends to remove private and local bills from the general field of political discussion, and thus helps to rivet

${ }^{2}$ S. O.P. B. pp. $98,103,105-106,108$, 1 10-113, 116-117, 208. Until a few years ago there was a paid referee who could sit on the committee with an advisory voice but no vote. May, p. 728 . There were formerly two paid referees, and later only one. The procedure is slightly different in the case of railway, canal, divorce, police and sanitary bills, but the principle is substantially the same.

${ }^{2}$ May, pp. 781-782.

3 For a careful study from this point of view of a fairly good legislative body, by one of its members well fitted to observe, see an article by Francis C. Lowell, in the Atlantic Monthly, lxxix. 366-377, March, 1897. 
the attention of Parliament upon public matters. A ministry stands or falls upon its general legislative and administrative record, and not because it has offended one member by opposing the demands of a powerful company, and another by ignoring the desires of a borough council. Such a condition would not be possible unless Parliament was willing to leave private legislation in the main to small impartial committees, and abide by their judgment.

\section{The House of Lords}

The upper house of the British Parliament contains several kinds of members, for it must be remembered that every peer has not a right to sit, and all the members are not in the same sense peers.

First there are the peers with hereditary seats. They consist of the peers of England created before the union with Scotland in 1707 , the peers of Great Britain created between that time and the union with Ireland in I8or, and the peers of the United Kingdom created thereafter. Their titles in the order of their rank are those of dukes, marquises, earls, viscounts and barons. At present they are about five hundred and fifty in number, and they increase continually, for the crown, that is the ministry of the day, has unlimited power to create hereditary peers of the United Kingdom.'

When the union with Scotland was made the Scotch peers were much more numerous in proportion to population than the English; and therefore, instead of admitting them all to the House of Lords, it was provided that they should

1 At one time the House of Lords held that a Scotch peer could not be given an hereditary seat as a peer of Great Britain; but this decision was afterwards reversed. A peer so created can still vote for representatives as a Scotch peer. Pike, Constitutional History of the House of Lords, pp. $3^{6 \mathrm{I}-3^{6} 3}$. 
elect sixteen representatives of their order for the duration of each Parliament. No provision was made for the creation of new Scotch peers, so that with the dying out of families, and the giving of hereditary seats to Scotch peers by creating them peers of the United Kingdom, the number of those who do not sit in the House has greatly diminished.

The same problem arose upon the union with Ireland a hundred years later; but in this case the Irish peers were empowered to elect twenty-eight of their number representatives for life, and it was provided that one new Irish peerage might be created for every three that became extinct until the number ${ }^{1}$ fell to one hundred, a limit above which it cannot be raised. ${ }^{2}$ There is another difference between the Scotch and Irish peers. The former are wholly excluded from the House of Commons, but the latter can be elected by any constituency in Great Britain.

The only spiritual peers in the House of Lords to-day are the English bishops, for the established church of Scotland is Presbyterian in form, and the Irish Anglican bishops lost their seats when their church was disestablished in 1869 . All the English bishops, moreover, do not have seats, because as the sees were increased it was not thought wise to enlarge the representation of the church; and, therefore, it was provided that the Archbishops of Canterbury and York, the Bishops of London, Durham and Winchester, and of the rest only the twenty seniors in the order of incumbency, should have seats in the House.

The House of Lords is not only a legislative chamber but also the highest court of appeal for the United Kingdom. When it acts as a court only those members who hold, or have held, high judicial office take part; but there are

1 Exclusive of those having hereditary seats under other titles.

2 The number is now less than one hundred. 
rarely enough of these for a court of last resort, and hence four additional judges are provided by the appointment of Lords of Appeal in Ordinary for life. It may be added that the presiding officer of the House is the Lord Chancellor, who fills at the same time the highest judicial office in the Kingdom.

\section{The Powers of the House of Lords}

Save for an ancient custom, rigidly insisted upon by the Commons, that the Peers must not initiate or amend bills to raise or spend money, the House of Lords had the same legislative rights as the other chamber until recent events brought a crisis in its history. It had always been in the habit of amending the measures of the cabinet, sometimes very freely. In fact the Lords were bolder in the twenty years preceding I 9 I I than they had formerly been. In I 893 they rejected Mr. Gladstone's Home-Rule Bill, and at the succeeding general election in 1895 the people appeared to ratify their action by returning a Unionist majority to Parliament. This emboldened the Lords to claim a right of appeal from the cabinet and the majority in the Commons to the electorate - a right, it was said, to demand a sort of referendum. That might have been well enough had not the House of Lords always acted with one of the great parties in the state and opposed the other. While the Conservatives were in power it was docile, but when the Liberals came into office in 1906 it rejected or mutilated a series of government measures.

Finally, in I 909 , the expense of old age pensions caused the Chancellor of the Exchequer to propose heavy taxes on the unearned increment - that is the increase in value of land, and on undeveloped land in or near cities, together with a supertax on incomes and an increase of the death duties. The Conservatives were exasperated, and when the 
finance bill came before the Lords they voted "that this House is not justified in giving its consent to this Bill until it has been submitted to the judgment of the country." The Liberal cabinet accepted the challenge, dissolved Parliament, and, although it lost seats at the election in January, Igro, it obtained a majority in the new House of Commons, and the finance bill passed into law.

\section{The Act of I9II}

The Liberals were not satisfied. They had made up their minds to restrict the power of the Lords, and a government bill was brought in for the purpose. Finding that the Lords were certain to reject it the cabinet again dissolved Parliament, and at the election in December, I9ro, was again victorious. The Commons passed the bill; the Lords still hesitated, but a threat to create peers enough to turn the scale brought many of them round. A majority of the Lords voted in its favor and it became law on August i8, I9II. ${ }^{1}$

In substance the act provides that if a bill to raise or expend money, which has been passed by the Commons and sent to the Lords at least a month before the end of the session, is not passed by them without amendment within one month it shall become an act on receiving the royal assent; ${ }^{2}$ and that if any other public bill passed by the Commons in three successive sessions is not passed by the Lords without amendments, or with such amendments as the Commons accept, it shall become an act on receiving the royal assent, provided two years have elapsed between the first and last vote in the Commons. On the questions

1 I-2 Geo. V, c. I3.

2 Provisions dealing with the raising and expenditure of money by local authorities are not included. 
whether a bill is a money bill or not, and whether the provisions of the act have been complied with, the decision of the Speaker of the House of Commons is final. Over money bills, therefore, the power of the Lords is virtually abolished, while on other bills it can propose amendments and can delay action for two years.

Restricting the power of the Lords was to be followed by a reorganization of the composition of their house. The problem, however, of constructing an upper chamber strong enough to be useful, and not so strong as to hamper a ministry responsible only to the Commons, is not a simple matter. The subject has been carefully considered by a commission, but as yet no action has been taken by Parliament.

\section{The Cabinet and the Country}

We have now considered the relation of the cabinet to the administrative service, to the House of Commons, and to the House of Lords. There remains to be touched upon its relation to the country.

If the predominance of the House of Commons has been lessened by a delegation of authority to the cabinet, it has been weakened also by the transfer of power directly to the electorate. The two tendencies are not, indeed, unconnected. The transfer of power to the electorate is due in part to the growing influence of the ministers, to the recognition that policy is mainly directed, not by Parliament, but by them. The cabinet now rules the nation by and with the advice and consent of Parliament; and for that very reason the nation wishes to decide what cabinet it shall be that rules. No doubt the ministry depends for its existence upon the good pleasure of the House of Commons; but it really gets its commission from the country as the result of a general election. 
The passing of political power from the House of Commons to the people is shown by many unmistakable signs, and by none more clearly than by the frequent reference in Parliament itself to the opinions of the " man in the street." He is said to fear this, or be shocked by that, or expect the other; and the House is supposed to pay some regard to his views. Then there is the fact that Parliament is no longer the only place where the party leaders make notable speeches. In short, the predominance of the House of Commons as the great forum for the discussion of public questions has been undermined by the rise and growth of the platform. It has now become a settled custom for the cabinet ministers and the leaders of the parliamentary Opposition to make a business of speaking during the late autumn and the spring recess; and the habit tends to magnify their power, for they are the only persons who have fully the ear of the public. Frequent public addresses by the men in whom the whole responsibility for the conduct of national affairs is concentrated, and by those who will be responsible when the next change of ministry occurs, cannot fail to educate the voters, and quicken their interest in all the political issues of the day. The rulers of the country, and those who both have been and will be her rulers, fight at close range across a table for six months of the year, and during the rest of the time they carry on the ceaseless war by public speaking. As in the Athenian democracy, the citizens witness a constant struggle among rival statesmen for supremacy, but in England they are merely spectators until a general election summons them to give their verdict. One can hardly conceive of a system better calculated to stimulate interest in politics without instability in the government. 


\section{CHAPTER III}

\section{ENGLAND: PARTY}

\section{Parties during the War}

A FEw months after this war broke out a coalition cabinet was formed. Both parties rallied to the support of the government, and during the war there has been a truce in the usual party struggles. The ministry and the front opposition bench have not been fighting across the table, and, therefore, the whole working of parliamentary institutions has undergone a change. To sustain the government in its colossal task, new offices have been created, with ministers to conduct special departments of the military service. A war cabinet of four members, some of them without departmental duties, has been set up. What its functions really are, how great is its influence in policy and administration, cannot yet be accurately stated. Nor for our present purpose is it needful to attempt to do so; for these are not normal times, and the object of this book is to describe the regular, the habitual, the natural working of the English form of government, and that is bound up with the interaction of the political parties and of their leaders on the two front benches. When the war is over, the currents of public life will return to peaceful channels; not, indeed. to precisely the same condition as before the war-the shock has been too great for that - but to a normal political activity of some kind. Parties may well be formed on a new basis, with new lines of cleavage, but there is no reason to suppose that they will permanently disappear; and, therefore, the value of a study of the working of parties under the English parliamentary system permanently endures. 


\section{Parties in Modern Government}

Experience has shown that democracy in a great country, where the number of voters is necessarily large, involves the existence of political parties; and it would not be hard to demonstrate that this must in the nature of things be the case.

But if political parties have become well-nigh universal at the present time, they are comparatively new in their modern form. No one in the eighteenth century foresaw party government as it exists to-day, enfolding the whole surface of public life in its constant ebb and flow. The expression, "His Majesty's Opposition," said to have been coined by John Cam Hobhouse before the Reform Bill," would not have been understood at an earlier period; and it embodies the greatest contribution of the nineteenth century to the art of government - that of a party out of power which is recognized as perfectly loyal to the institutions of the state, and ready at any moment to come into office without a shock to the political traditions of the nation.

\section{Party and the Parliamentary System}

In England the party system is no more in accord with the strictly legal institutions, with King, Lords and Commons, than it is elsewhere; but it is in absolute harmony with those conventions, which, although quite unknown to the law, make up the actual working constitution of the state. It is in harmony with them because they were created by the warfare of parties, were evolved out of party life. It is based upon party, and by the law of its nature tends to accentuate party. Ministers perceived that their security

${ }^{1}$ Cf. Review of his unpublished "Recollections of a Long Life," in the Edinburgh Review, April, I87I, p. 301 . 
depended upon standing together, presenting a united front, and prevailing upon their friends to do the same. The leaders of the Opposition learned also that their chance of attaining to power was improved by pursuing a similar course. In this way, two parties are arrayed against one another continually, while every member of Parliament finds himself powerfully drawn to enlist under one banner or the other, and follow it on all occasions. He cannot consider measures simply on their merits, but must take into account the ultimate effect of his vote. As soon as men recognize that the defeat of a government bill means a change of ministry, the pressure is great to sacrifice personal opinions on that bill to the greater principles for which the party stands; and the more fully the system develops, the clearer becomes the incompatibility between voting as the member of Parliament pleases on particular measures, and maintaining in power the party he approves. In short, the action of the House of Commons has tended to become more and more party action, with the ministers, as we have already seen, gradually drawing the initiative in legislation, and the control over procedure, more and more into their own hands. In fact, so far as Parliament is concerned, the machinery of party and of government are not merely in accord; they are one and the same thing. The party cabal has become the Treasury Bench. The ministers are the party chiefs, selected not artificially but by natural prominence, and the majority in the House of Commons, which legislates, appropriates money, supervises and controls the administration, and sustains or discards ministers, is the party itself acting under the guidance of those chiefs. The parliamentary system, as it has grown up spontaneously in England, is in its origin and nature government by party, sanctioned and refined by custom. 


\section{Party Votes in Parliament}

Since the cabinet may be overturned at any moment, so that its very life depends upon incessant warfare, it must try to keep its followers constantly in hand; and since every defeat, however trivial, even if not fatal, is damaging, it must try to prevent any hostile votes - an effort which explains in part the much larger average attendance at divisions to-day than in the first half of the last century. Thus from the side both of the private member and the responsible minister there is a pressure in the parliamentary system towards more strict party voting. A democracy prefers broad contrasts, sharply defined alternatives, clearly marked issues and the frank opposition of party leaders. It understands better the struggle between the two front benches than the particular bearing of the measures debated. Unless matters of local interest are involved - and these the English practice almost eliminates - a democracy is prone to support the party, with comparatively little regard for matters of detail.

In Parliament contentious legislation is in ordinary times conducted in the main by one party and opposed by the other, and hence the proportion of party votes is nearly constant. In Congress this is by no means true, and the number of such votes depends largely upon the presence of some question on which the parties happen to be sharply divided. On other subjects party lines are less strictly drawn. In short, in England the parties frame the issues; in America at the present day the issues do not, indeed, make the parties, but determine the extent of their opposition to each other in matters of legislation. In general the statistics for Congress show that whereas during the middle of the last century the amount of party voting there was at least 
as great as in Parliament, and while in particular sessions the English maximum has been exceeded, yet on the average, party lines are now drawn distinctly less often than in the House of Commons. ${ }^{1}$

It is often said that in State legislatures the boss, or the caucus, dictates the action of the party on pending measures, and then carries it into effect by a party vote, so that legislation is really the work of the machine. That this is an error is proved by the statistics. It is not true, because in the first place the machine rarely controls more than a part of the members of the party, and in the second place the machine meddles little with general legislation. It knows that an attempt to dictate to its followers on such questions would only weaken its authority; and hence it confines its attention to the distribution of spoils, to laws that bear upon electoral machinery, and to such bills, public or private, as affect directly the persons from whom it draws its revenue. It has, indeed, been pointed out that the very position of the boss depends upon the fact that parties exist for public objects, while he exists for private ones; ${ }^{2}$ and this is so well recognized that great corporations desiring to obtain either selfish legislation, or protection against unscrupulous attack, have subscribed impartially to the campaign funds of both political parties. That is the aspect of public life which provokes an outcry from reformers. Parties in America are not, as a rule, despotic on public questions, because they have little cohesion; but their influence, or rather the influence of the machine, or of the individual politician, is freely exerted in things quite apart

1 For an claborate collection of statistics, see the writer's tables in the Report of the American II istorical Association for $190 \mathrm{r}$, and for a brief summary his Government of England, ii. 72-92.

2 "The American Boss," by Judge Francis C. Lowell, in the Atlantic Monthly, September, I900. 
from those issues of public policy which form the only rational ground for party activity. In short, the boss is not a prime minister who directs policy, but an electioneering agent and a private bill and office broker.

A comparison of England and America shows, therefore, that the influence of party upon legislation is, on the whole, much greater in England, but that it is more closely confined to public measures. 


\section{CHAPTER IV}

\section{ENGLAND: LOCAL GOVERNMENT}

\section{The Areas of Local Government}

THE whole country is divided into counties ${ }^{1}$ and county boroughs, the larger towns being for administrative purposes counties by themselves. ${ }^{2}$ Each of these divisions is governed by a single body called the council, composed of representatives popularly elected by wards, and of additional members, called aldermen, chosen by the council itself. The details are slightly different in the counties and county boroughs, but the general principles are the same; and in the latter the county powers are simply vested in the same council that governs the borough in other respects.

The county is subdivided into boroughs and urban and rural districts, each of which is governed by a council

1 This is properly called the administrative county to distinguish it from the ancient county or county at large, from which it differs by the exclusion of the county boroughs, and by the changes in boundaries made in consequence of the Acts of 1888 and I 894 . The county at large still exists for elections to Parliament, and in some cases for judicial purposes and for the militia, although as a general rule these last two matters follow the changes made in the administrative county. ( $5 \mathrm{I}-52$ Vic., c. $4 \mathrm{I}, \S 59$.) There are in England and Wales only fifty-two counties at large, but in consequence of divisions for purposes of local government there are sixty-two administrative counties, only half a dozen of which now coincide in area with the counties at large.

2 This privilege was intended for boroughs which had, or should thereafter attain, a population of 50,000 , although some smaller places were included in the list because they were already counties by themselves. $\left(5^{1-52}\right.$ Vic., c. 4I, $\S 3 \mathrm{I}, 54$, and Sched. 3; cf. Wright and Hobhouse, Local Government, $2 \mathrm{~d}$ ed., pp. 24-26.) 
formed on the same plan as a county council, save that in the district councils there are no additional members, or aldermen, elected by the council itself. ${ }^{1}$ The functions of these councils differ very much, those of the boroughs being the most, and those of the rural districts the least, extensive. For that very reason the boroughs and urban districts, and of course the county boroughs, although usually divided into wards for electoral purposes, can hardly be said to be subdivided for local government, the powers of urban parishes being insignificant. The rural districts, on the other hand, are divided into parishes which possess real functions, and were intended, at least, to take an active part in local administration; those with more than three hundred inhabitants having elected councils, and the rest transacting their business in mass meeting. ${ }^{2}$

The metropolis does not fall into this system of local government, but is organized on a plan of its own. The City of London, with its ancient limits, retains its old institutions, independently of the vast town that has grown up around it; while the rest of the metropolitan area is under a county council, created at the same time, and on the same general pattern, as other county councils. The territory over which it rules was divided in 1899 into boroughs, with councils to which the powers of the former parish vestries have been transferred; ${ }^{3}$ and thus London is treated as a borough of the second degree.

$156-57$ Vic., c. $73, \S \S 23-24$.

2 In the past there have been many kinds of parishes (Odgers, pp. 44-48. Wright and Hobhouse, pp. I-8. Redlich and Hirst, Local Government, ii. I6 II 70), but now there are only two of any real importance, the poor-law or civil, and the ecclesiastical, parish. By two distinct series of acts the parishes of both kinds have been so changed that in most cases the ecclesiastical no longer coincides with the civil parish. The former is under its own vestry and churchwardens, who have now no civil powers.

${ }^{3}$ 62-63 Vic., c. 14. 
Cutting athwart this checkerboard of local areas the only important cross division remaining, that of the poor-law unions, covers the whole country with another network of lines. The members of the board which rules the union are still called guardians, and in the urban parts of a union they are separately elected, while in the rural parts they are simply the members of the rural district council elected there.

Described in this way the scheme of English local government may not seem complex, but in fact it is less simple than it appears, because there are in many places divers peculiarities and exceptions, under ancient local customs and special local acts, which mar the symmetry of the plan.

\section{Borough Councils}

All the larger boroughs, and many of the smaller ones, are divided into wards, among which the seats in the council are apportioned. ${ }^{1}$ As a rule - although by no means an invariable one - each ward is represented by three councillors; and since they serve for three years, one of them retiring each year, the voters in a ward are usually called upon to elect only a single representative at the annual election. As in the case of Parliament, no poll is held unless more candidates are nominated than there are seats to be filled, and hence an opponent does not come forward unless he means to conduct a serious fight. The result is that in many a ward there is no contest, especially when the sitting member is ready to stand again. The number of uncontested seats varies, of course, a great deal. In one hundred and three boroughs and urban districts, large and small, taken

1 The division into wards is based upon local taxation as well as population, and thus a certain weight is given to property. $45^{-4} 4$ Vic., c. $50, \S 30$ (I0). For the relations of population and property in the wards of Glasgow see Bell and Paton, Glasgowi, p. 63. 
at random at the elections of 1899 , decidedly less than half the seats in the aggregate were contested, while in thirteen of these places there was not a single contest.

The borough council is not composed of representative members alone. It consists of the mayor, aldermen, and councillors sitting together as a single body. The aldermen are in number one third as many as the councillors; but although selected in a different way, and holding office for a different term, they are from a legal point of view simply members of the council like the rest. They are chosen for six years instead of three, one half of them going out every third year. They are elected by the council itself on November 9, that is immediately after one third of the council has been renewed by the popular election of that year. ${ }^{1}$

While the aldermen have no important legal powers not enjoyed by the other members of the council, their influence is much greater, for they are the members who have served longest, and they hold most of the chairmanships upon the committees. In some towns, indeed, these posts are reserved exclusively for them, and everywhere one is struck by the fact that they are, on the whole, the leading figures in the council. The influence naturally conceded in a body of this kind to seniority and experience is enhanced in an English borough council by the fact that as a general rule, apart from a change of party in the council, retiring aldermen are reëlected so long as they are willing to serve. ${ }^{2}$

1 Formerly, the aldermen voted in the election for aldermen, and this gave them in some cases a power to retain the majority of the council in the hands of their own political party after the majority of popularly chosen councillors had passed to the other party. In IgIo their right to vote for aldermen was taken away by statute. (Io Edw. VII and I Geo. V, c. I9.)

${ }^{2}$ It is not an invariable rule. In Carlisle and Oldham, for example, an alderman is not reelected, on the principle that after serving his term of six years he ought to go back to his constituents for approval. But this is not considered by most observers to work well. 
This may not be in accord with the strict theory of representative government, but it has substantial advantages. It insures the presence in the governing body of men of long experience; and in fact it is not uncommon to find in a town council a few men who have served there continuously for twenty-five or thirty years, or even more.

\section{The Mayor}

The first business of the council at the meeting on the ninth of November is the election of a mayor, for the term of one year, from among the aldermen, councillors or persons qualified to be such. The mayor is a justice of the peace for the borough during his term of office, and for one year thereafter; but this is the only duty of importance that he performs apart from the council, of which he is both a member and the chairman.

\section{The Permanent Officials}

Behind the council and its committees, little seen by the public, but carrying the main burden of the public work, stand the permanent officials. When a vacancy occurs in the position of a town clerk or borough surveyor, for example, it is the general, although not invariable, habit to advertise for a successor; and this is sometimes done even in cases where the councillors have really made up their minds to promote a subordinate already in the service of the borough. If a promotion of that kind is not made, and a clerk, engineer or other officer is appointed from outside, a man is usually selected who is employed in a similar public office elsewhere - either at the head of a department in a smaller place, or as a subordinate in a larger one. In this way municipal service tends to become a career by itself. A town clerk, for example, must always be a solicitor or 
barrister by profession, and occasionally a person in private practice is selected, but it is far more common to take a man who is already engaged in municipal work, and has therefore had experience in the particular class of duties he is called upon to perform. In short, a town clerk usually enters the public service as a young man in a subordinate capacity, often as an articled clerk in a town clerk's office, and works his way up. It is rare that a solicitor is put into one of the higher posts in a borough from private life, and rarer still that a town clerk, or one of his assistants, goes back into private practice. The same thing is true of the engineers. It is not common to appoint a borough engineer on account of his reputation in general practice; or for a man who has seen service as an engineer of a town to go back into any other kind of work. In short, municipal engineering tends to become a distinct profession. The officials abstain wholly from party politics, and although party motives may have affected the choice of a man, they never lead to his discharge if the majority in the council happens to change. In short, there are no spoils, or rather nothing of the practice that renders spoils a blight - that is, the removal of officeholders to make room for partisans. So long as an English borough official does his work well, he is retained regardless of party.

\section{Their Position}

It is often said that the council determines the general policy to be pursued, while the officials carry it out in detail, ${ }^{1}$ and this describes, no doubt, the legal situation, but

1 Redlich and Hirst (Local Government in England, i. 350-351), who have dwelt upon the importance of the officials more than any one else, repeat this statement in a slightly different form; and although they point out that it is not accurate, they seem to regard it as more nearly so than it appears to the writer. 
it is very far from expressing the actual influence of the officials upon the administration of the borough. In the first place no sharp line can be drawn between policy and details; and then an official who has in any degree the confidence of his committee will always influence them very largely about the general policy of his department. His position is like that of a permanent undersecretary of state. The members of the council, like the ministers, assume the responsibility for what is done. They are expected to shield the official from blame, and naturally take the credit for good management. He enjoys, therefore, with a large share of real power, freedom from attack, and a permanent tenure of office in consideration of self-effacement. It is not inaccurate to say that in general the chairman of a committee plays a part not unlike that of a minister, with the official as his permanent undersecretary. The official impresses his views on the chairman, who in turn impresses them on the committee, and this body carries them through the council. Thus the motive force behind the council is to be found mainly in the permanent officials, whose power, being unseen, is little understood by the public. In fact the writer, after studying a number of English cities, was led to imagine that the excellence of municipal government was very roughly proportional to the influence of the permanent officials. That influence, be it observed, is by no means confined to matters where purely expert knowledge is required. A very small fraction of the time of a town clerk is devoted to questions of law, or of a surveyor to engineering problems. By far the greater part of their work is administrative, and it is not too much to say that the administration of a typical English borough is conducted by the officials. 


\section{Benefits of their Influence}

The merits of English municipal government have been commonly attributed to the concentration of power in the hands of the council, but in its essence the system is virtually that of management by committees; and such a system, by its very nature removed in details from public observation, is singularly open to abuse. There is probably no method of government that in bad hands lends itself more readily to inefficiency and corruption than administration by committees, and none that is less sensitive to healthy criticism. But it works very well where, as in the English borough councils, the committee acts under the guidance of upright and capable experts. Under these circumstances the officials, who really administer the city, find support, protection, and permanence of tenure; while at the same time they are prevented from becoming bureaucratic, and are kept in touch with public opinion. 


\section{CHAPTER V}

\section{ENGLAND: THE EMPIRE}

\section{The British Empire}

Tre dependencies of England are scattered over the whole face of the earth in almost every habitable latitude, while there are scarcely ten consecutive degrees of longitude in which she does not have a foothold. Including Egypt, her six most important possessions lie in five different continents with no means of communication between them but a long sea voyage. Outsicle of the British Isles with their hundred and twenty thousand square miles, she holds no land in Europe of other than a military significance; but she has nearly four millions of square miles in North America, as much more in Africa, ${ }^{1}$ over three millions in Australasia, and nearly two millions in Asia, besides innumerable islands and small bits of coast dotting the map of the world.

\section{Proportion of Races}

The population of the empire is as diverse as its geography. Only a small fraction of it is of European origin, and that fraction is far smaller than it was a hundred and fifty years ago, for by the annexation of huge territories the number of Asiatics and Africans under British rule has been multiplied enormously, while the people of European race in the dependencies are only about four times as many as they were at that time. In fact, the ratio of the people

1 Including Egypt and the Sudan; but not including the captured German colonies. 
of European stock in the rest of the empire to those in the British Isles is little, if any, larger than it was in 1775 . The revolt of the American colonies did not, as some people believed at the time, prevent England from building up a great empire, but it has so far prevented that empire from being in large part Anglo-Saxon. The British dominions, including Egypt and the Sudan, but not including the captured German colonies, contain a total population of about four hundred and fifty millions; of which the people of European descent number about sixty millions; the natives of India over two hundred and ninety-five millions; African races of all kinds, from Egypt to the Cape, some sixty-two millions; the rest being Chinese, Singalese, Malays and aboriginal races of various kinds.

\section{Distribution of the European Elements}

Of the sixty millions of people of European stock, over forty-five millions live in the United Kingdom, and less than fifteen millions elsewhere. Nor are these last gaining at such a rate of speed as to make it probable that they will soon overtake the mother country. Moreover, the fifteen millions of European origin in the colonies are by no means wholly of British extraction. Apart from streams of foreign immigrants who will soon become intermingled with and assimilated by the people among whom they live, there are certain old stocks, original settlers or ancient inhabitants, like the French Canadians, the Cape Dutch and the Maltese, who have not lost their language or their traditions. They number some three millions, leaving not much more than a dozen millions of English-speaking subjects outside the British Isles. 


\section{Revenue}

Unlike the outlying portions of most of the great empires in the past, the dependencies of England are not tributaries. Normally each colony, whether self-governing or not, is self-supporting. It contributes nothing to the imperial treasury, and the mother country defrays no part of the cost of its administration. India, for example, maintains the British troops stationed there, and pays both the salaries of English officials in her service and their retiring pensions after they leave; but although this may be an advantage to England, the money is spent solely on the government of India and in principle at least for her benefit. In time of peace, no more troops are, in fact, kept at the expense of the country than are deemed to be needed for its defence and for the preservation of order. Occasionally England advances money to one of the colonies to be repaid later, but she never extorts a loan from them.

Of late years the self-governing colonies have, indeed, undertaken to maintain ships of war, but they are designed chiefly for the protection of their own coasts, and are insignificant in comparison with the cost of the British navy.

So far from regulating trade during the last half century for her own benefit, England in granting self-government to her larger white colonies allowed them to raise their revenues as they saw fit, and they have set up protective tariffs against her manufactures. Recently they have, indeed, given a preference in rates to English goods, although sometimes merely by raising their duties still more against other nations. The profit that England derives from her dependencies does not come in the form of tribute, but of enlarged opportunities for her citizens. Much discussion has taken 
place on the question whether trade follows the flag, ${ }^{1}$ but whether it does so directly or not, there can be little doubt that the control of an immense empire has had an indirect effect in the past.

\section{Forms of Colonial Government}

There are now three distinct types of colonial government to be found in the British Empire: those of the self-governing colonies, the crown colonies, and what for want of a better generic term may be called the protectorates, that is, the states that are administered more or less completely by England through the form of advice to the native rulers. This is not wholly the official classification, because some of the dependencies are not under the Colonial Office, and hence are regarded as distinct from the rest. India, for example, being in charge of the India Office, is not called a colony, and yet the method of administration is essentially similar to that of a crown colony so far as the connection with the parent state is concerned. Egypt, also, is not classed as a colony at all, because nominally not a British possession, and practically administered by the Foreign Office. $^{2}$ But if we disregard the question from which corner of the great building on Downing Street a dependency is ruled, and look merely to the actual forms of government, we find that they fall very comfortably under one or other of these three heads.

\section{The Self-Governing Colonies}

Before the eighteenth century was far advanced a single type of government had become prevalent in most of the

1 There is an interesting study of the question in Alleyne Ireland's Tropical Colonisation.

2 So the African protectorates, ruled under the Foreign Jurisdiction Acts, are classed here as crown colonies. 
important British colonies, both on the mainland of North America and in the West Indies. It was that of a governor appointed by the crown, and a legislature with a popular branch elected by the inhabitants of the colony and possessing the power of the purse. For any people with English political traditions that was the natural form to adopt. It is the type followed by the United States for the government of her territories. As a temporary expedient, while a territory is too thinly settled to be admitted to statehood, the plan has worked well in the American republic; but as a permanent system in a community mature enough to have a will of its own the plan has grave defects. It involves dissensions between the ruling powers with no arbiter to whom both feel bound to submit; and in fact the history of the British colonies in the eighteenth century is full of bickerings between the governor and the legislature. ${ }^{1}$ These disputes harrowed the ground in which the seeds of the American revolution were planted.

The first serious attempt to study the effects of this form of colonial government was made after the Canadian Rebellion of I837. Lord Durham was sent out as High Commissioner, and in his famous report he pointed out the evils of the plan, suggesting as a remedy that the governor of each province should entrust the administration to such men as can command a majority in the Assembly, and thus establish ministerial responsibility on the English pattern.

A decade later, his suggestion was carried out by Lord Elgin who became Governor of Canada in 1847 ; and within ten years it was applied to the principal Australian colonies also. In fact it has been extended to every British colony

${ }^{1}$ Cf. Greene, The Provincial Governor; Egerton, Short History of British Colonial Policy. 
as soon as it contained a sufficiently large population of European stock.

\section{Colonial Federations}

A sequel to the grant of responsible ministries has been the formation of confederations in the three great groups of self-governing colonies. In each case the initiative has come from the colonies themselves, the action of the mother country being almost entirely confined to embodying in an Act of Parliament the plans already agreed upon by them. The British North American Act of $1867^{1}$ brought together in the Dominion of Canada the provinces of Ontario, Quebec, Nova Scotia, and New Brunswick, and later all the other habitable parts of British North America joined the union, except Newfoundland and its dependency Labrador. A generation later all the Australasian colonies, except NewZealand, were brought together by the Commonwealth of Australia Act of $1900{ }^{2}$ and finally the South African colonies were united under a federal constitution in I909. ${ }^{3}$ These federations differ a good deal in details, but each of them has a federal ministry responsible to a federal parliament, and provincial ministries responsible to assemblies for the province or state.

\section{The Relation to England}

The organization and internal government of these confederations do not fall within the scope of this book; but it may be observed that their formation has not been without effect on the relation of the colonies to the mother country. Instead of dealing with a dozen and a half communities, many of them very small, while the largest has scarcely more than two million people, she deals mainly

${ }^{1} 30-3$ I Vic., c. $3 . \quad 263-64$ Vic., c. I $2 . \quad{ }^{3} 9$ Edw. VII, c. 9. 
with three federations, one of which contains four and a half and another over seven million inhabitants. She comes into contact with national instead of provincial opinion, and this of itself tends to lessen the part she plays in their domestic affairs.

The influence of England over her self-governing colonies is now exerted through four channels: the royal governor, the right to veto legislation, the control of foreign relations, and the appeals from the colonial courts to the Judicial Committee of the Privy Council.

The governor in a self-governing colony has two functions. $\mathrm{He}$ is an officer of the mother country appointed to guard her rights and exercise a great part of the control she still retains over the colony; and he is also the chief magistrate of the colony for its own internal government. According to this distinction it is commonly said that in matters that affect other parts of the empire or foreign countries he must use his own discretion, or seek instructions from the Secretary of State in England, while in matters that affect only the internal affairs of the colony he must follow the advice of his ministers there. The first part of the statement is not, however, perfectly accurate. A protective tariff, for example, affects very seriously both the rest of the empire and foreign nations, yet it is well settled that the governor cannot on that account refuse his assent to it. His position as the representative of England is sometimes a delicate one, and his chief usefulness lies rather in his moral influence than in his legal authority.

The veto is not, as in England, virtually obsolete, for some acts passed by the self-governing colonies have usually been

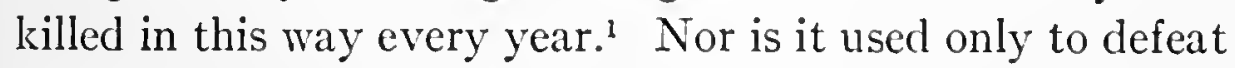

${ }^{1}$ Com. Papers, rgor, xlvi. 7 , gives a list of recent cases where this has occurred. 
measures prejudicial to other parts of the empire or to foreign countries, although that is, of course, its main object at the present day. Not very long ago acts regulating elections and the franchise in Newfoundland and Natal were refused assent. But it may be observed that the extent to which the veto has been used for bills relating chiefly to domestic affairs is inversely proportional to the size of the colony.

The actual relation of England to the self-governing colonies may not be easy to classify in the terms used by publicists when they discuss sovereignty; but there is no doubt that as regards foreign nations the British Empire has been treated as a single power, and that power is England. In order, however, to satisfy colonial opinion it is the habit when a really important question arises -- between Canada and the United States, for example - to appoint a commission containing colonial members. But the situation is not wholly comfortable, and would be much more difficult were it not that the remoteness of these colonies saves them to a great extent from complications with other countries. If the grant of self-government has reduced greatly the control of England over the colonies inhabited by people of her own race, it has also removed almost altogether the friction that existed formerly and has allowed a strong imperial sentiment to grow up. The diminution of power has been followed by an increase of loyalty. Other conditions have promoted this feeling, not least among them a change of attitude toward these colonies in England itself. One has heard nothing for many years on either side of the ocean about eventual independence. In its place one finds speculation about possible means of drawing the parts of the empire closer together. 


\section{The Crown Colonies}

A colony can be governed by its own people, or it can be governed by the mother country, but under ordinary conditions it cannot be governed successfully by a combination of the two, and hence the English dominions over sea are sharply separated into two groups: one that of the selfgoverning colonies, which have tended towards more and more complete control of their own affairs; the other that of the crown colonies, which have tended to lose the remnants of self-government that they possessed. Of the old type, with an assembly wholly elected, and a governor whose ministers are not responsible to the legislature, only three examples remain. They are Bermuda, Bahamas, and Barbados, the first and last having the oldest representative bodies in the British Empire except the House of Commons. The peculiar conditions in those islands, that have made possible the survival of institutions which have perished elsewhere, need not be examined in detail. Suffice it to say that they are peculiar, although not the same in each case.

The rest of the crown colonies may be divided into three classes. First, the Leeward Islands, British Guiana, Malta, Mauritius, and Fiji, where the legislative body includes elected members who are, however, in a minority.' Where the population contains any considerable number of Europeans, or other educated people, this has the advantage of bringing the governor and his advisers into official contact

1 British Guiana has a curious constitution derived from the Dutch. In the Court of Policy, which deals with ordinary legislation, the government has a bare majority; but the Combined Court that levies the taxes is formed by adding other elected members. For the method of controlling this body, see Ireland, Tropical Colonisation, pp. 45-51, 65-66.

Cyprus alone has a legislative body containing both elected and appointed members with the former in a majority. This is normally the case in Jamaica also; but there the majority can be turned into a minority at any time. 
with an enlightened local opinion which, in the absence of violent dissensions, is likely to have great weight. The second class of crown colonies is the most numerous of all, and consists of those where the legislative body is wholly appointed. This is true, for example, of the remaining British possessions in the West Indies and Central America, of Ceylon and of most of the colonies on the tropical coasts of Africa. ${ }^{1}$ It is almost a necessity where the proportion of European residents is minute, or where they do not truly represent the local industries. Finally, in purely military stations like Gibraltar and St. Helena, and in half explored tracts like some of those in the interior of Africa, the governor has no legislative council whatever.

\section{India}

The Governor-General, or Viceroy, of India and the Czar of Russia were sometimes said to be the two great autocrats of the modern world. But, save in the case of a man of rare capacity and force, an autocrat, especially if like the viceroy he comes for a few years to a strange land, must be largely under the influence of advisers who are thoroughly familiar with the work to be done; and this is the more true when those advisers, including his own private secretary, belong to a great organization with a strong esprit de corps. The governors of Bombay and Madras, like the viceroy himself, are English noblemen appointed directly by the crown, but they must obey his orders, their legislative power is limited, and all laws made by them require his consent. ${ }^{2}$ Hence their authority is not very great

1 In Hong Kong and the Straits Settlements the Legislative Councils are wholly appointed, but in cach case a couple of members are nominated by the chambers of commerce or other bodies.

2 Ilbert, The Government of India, pp. 190-191, 221-222, 225. 
and they, too, are surrounded by members of the civil service. The lieutenant-governors, or chief commissioners, at the head of the other provinces, are appointed by the viceroy, and are regularly selected from the civil service; for which, indeed, by far the greater part of the administrative and judicial posts of higher grade in India are reserved.

\section{The Civil Service of India}

Except for a number of seats in the high courts and in the councils of the various governors, and for special services, organized and recruited separately, like engineering, forestry, police, and education, it may be said that almost all the offices of government involving any serious responsibility are held by members of the civil service of India. ${ }^{1}$ From their ranks are taken the collector magistrates in the several districts, who carry on the actual government throughout the country, and have charge of almost every branch of the administration, ruling, on the average, over nearly a million of people apiece. ${ }^{2}$ A few of the principal subordinates in the districts are also members of the service, the other offices, mainly of a lower grade, being filled by natives of the country. Thus the government of India is really in the hands of about eleven hundred Englishmen, of whom a couple of hundred are military officers or uncovenanted civilians, while all the rest belong to the great corps of the civil service. ${ }^{3}$ Its members go to India at not over twenty-four years of age, and after spending twenty-five years there they are entitled to retire with a liberal pension. Such a body of men, drawn for the most part from one

1 Ilbert, pp. r26-r 28, 238-240, 276-277; Lowell and Stephens, Colonial Civil Service, pp. 50-53.

2 The corresponding officer in the non-regulation provinces is styled Deputy Commissioner.

Lowell and Stephens, pp. 56-57. 
source, nurtured by the English universities, spending their vigorous years in a common and highly responsible work in an Oriental land, are well fitted to develop traditions without bureaucratic rigidity. They do not conceive of their mission as ruling India for the benefit of England, and, in fact, without recognizing any conflict of interest between the two, their first care is the welfare of India as they understand it.

The Indian Councils Act of 1892 , or rather the regulations made thereunder, introduced a trace of representation in to the general government of India. They provided that in the legislative councils of the chief provincial governors a part of the members should be appointed on the nomination of municipal and district councils, of landowners, manufacturers, and tradesmen; others being appointed by the governor "in such manner as shall in his opinion secure a fair representation of the different classes of the community." Although the legislative councils so constituted have little actual power, they not only debate proposed changes in the laws, but can also discuss the annual financial statement, and ask questions after the manner practised in the House of Commons. All this gives serious native opinion some chance to make itself heard by the rulers, and provides a valuable means of obtaining information. ${ }^{1}$

\section{India is not a Nation}

The people of India are not a nation, but a conglomerate of many different races and religions, often side by side in the same place yet unmixed and sharply separate. It is this, as Seeley pointed out in his "Expansion of England," that has enabled the British to conquer and hold the coun-

1 The Indian Congress, of which we have heard so much of late years, is an unofficial body. 
try. If the inhabitants should act together, and were agreed in wanting independence, they could get it. In short, if they were capable of national self-government, the English would live on a volcano, and their occupation would be brief. The Mutiny was suppressed because it was not universal. The Sikhs helped to put down the Sepoys; and so long as large sections of the people distrust one another more than they do the English, disaffection has little chance of achieving any notable result.

\section{The Native States}

The whole of India is not under direct British administration. Scattered all over the peninsula are tracts of country under native rulers, although subject to the overlordship of the English crown. Lee-Warner styles the relation one of subordinate union, and certainly it is very far from an international connection between sovereign states, because the government of India exercises in several ways a paramount authority, not only for its own security, but also for the protection of the native ruler's own subjects. Speaking generally, the native states are protected against both external foes and rebellion at home, and, on the other hand, their diplomatic intercourse with one another and with foreign powers is in the hands of the Indian government. They have military obligations, also, which vary a good deal according to the special treaties made with them. Quite apart from military necessities, moreover, they must permit the construction of roads, railways, telegraphs, and irrigation works within their limits. The instrument through which the control of the native states is carried on is the resident, whom the prince is bound to receive, and to whose advice he must listen. He need not always follow it, but the admonitions of the resident count for much in 
the long run. By pressure of this kind, and by intervention in flagrant cases, the bands of thugs, and barbarous customs like infanticide and suttee, have been abolished in the native states, which have indeed tended in many ways to follow at a distance the example of British India.

\section{Egypt}

The other recent example of preserving the local ruler and controlling him by means of an English adviser, that of Egypt, is better known. Although in theory the occupation by England is still temporary, Egypt is really her permanent possession, the gateway to the East which she cannot surrender. Although the ministers of state are Egyptians, behind each of them stands, as adviser or undersecretary, a British officer whose suggestions he must obey; while above them all, as adviser to the Khedive, the English Agent and Minister Plenipotentiary is the real ruler of the country. Considering the difficulties encountered, the various interests involved, and the temporary nature of the first occupation, the administration of Egypt must be regarded, in spite of criticisms of detail, as one of the most signal achievements of English skill in the management of dependent states.

\section{Imperial Federation}

No change of political sentiment in England within a generation has been more marked than that toward the colonies. The fatalistic indifference that was widespread fifty years ago has been replaced by an almost universal desire to draw closer the bonds that connect the mother country with her grown-up children, as orators are fond of calling them. What imperial federation means is, therefore, an important matter for consideration; and first it may be observed that it can apply only to the self-governing colo- 
nies. Dependencies that do not govern themselves might be taxed for the support of general defence, but they can obviously take no part in the government of the empire. If they cannot rule themselves, they certainly cannot rule other people, and to go through the form of having them do so would be worse than illusory. If India, for example, or the West Indies, should appoint delegates to an imperial council, they would be merely agents of the English ministry, and would reduce the representatives of the selfgoverning colonies to an insignificant fragment of the body. India and the crown colonies must continue to be ruled by England, or, what is probably less desirable, by the federation as a whole, and they can take no real part in the united government. Nearly three hundred and seventy millions of British subjects can, therefore, have no active share in the federation, which would be practically confined to the United Kingdom with forty-five millions of people, and British North America, Australasia, and the Cape, with about fifteen millions among them. It would thus be a combination between one large state in Europe, and a number of small ones at great distances, containing in all only about one third of her population. These conditions must be borne in mind in discussing the possible forms of closer union; for while the ratio of inhabitants in different parts of the empire will, no doubt, change, a long time must elapse, as already observed, before the population of all self-governing colonies added together can equal that of the British Isles.

As in the classic case of the Greeks, the tie that binds the self-governing colonies to the parent state is based mainly upon sentiment. It is fortified, also, by common citizenship, and by a naval protection on the part of England to which the colonies make only a trifling contribution. The 
granting of responsible government was probably the only course that could have been pursued at the time, but although it did not lead, as some men then predicted, to separation, it was certainly not a step toward federal union. It placed the colonies in a position with which they do not seem to be dissatisfied." 'They are substantially free to manage their own affairs as they please, while on foreign matters that affect them, their opinions have great weight, and in time of peace they have the protection of England's name and navy almost without expense. The only important steps towards a closer political connection have hitherto been a series of consultations with the colonial premiers in London. But the vigorous and effective part voluntarily taken by the colonies in this war has made it clear that they must hereafter have a voice, at least, in the foreign relations of the Empire. How that roice shall be uttered, and what forms a closer connection will take, are problems which British and colonial statesmen must shortly face; but they are far from simple, and their solution is not easy to foresee.

1 Bernard Holland, in his Imperium et Libertas (pp. 297-298), quotes figures compiled by the Imperial Federation Committee in 1899 to show that the self-governing colonies, with close upon one third of the population of the United Kingdom, and nearly one half as much revenue, contributed less than one hundredth of the cost of naval defence. According to the figures compiled for the Colonial Conference of 1902 , the average naval expenditure per head of population in the self-governing colonies was $4 d$., while for the United Kingdom it was $I_{5} s$. $I d$. In the same way the military expenditure per head was $2 s$. $5 d$. against 14 s. $1 \frac{3}{4} d$. Com. Papers, I902, lxvi. $45 x$, p. 42 . 


\section{CHAP'TER VI}

\section{FRANCE: INSTITU'TIONS}

IN order to understand the government of a country it is not enough to know the bare structure of its institutions. It is necessary to follow the course of politics; to inquire how far the various public bodies exercise the authority legally vested in them; and to try to discover the real sources of power. It is necessary, in short, to study the actual working of the system; and although this depends chiefly upon the character, the habits, and the traditions of the people, it is also influenced in no small measure by details - like the method of voting, the procedure in the legislative chambers, and other matters - that are too often overlooked on account of their apparent insignificance. Now in several of the states on the continent of Europe the main features of representative government have been copied directly or indirectly from English models, while the details have grown up of themselves, or are a survival from earlier tradition. It is not surprising, therefore, that the two are more or less inconsistent with each other, and that this want of harmony has had a pronounced effect on public life.

\section{Origin of Parliamentary Government}

The Middle Ages gave birth to two political ideas. The first of these was a division of the people into separate classes or estates, each of which had independent political functions of its own. The second was representative government, or the election - by those estates whose members 
Were too numerous to assemble in a body - of deputies authorized to meet together and act for the whole estate. The number of these estates, and the number of separate chambers in which their representatives sat, varied in the different countries of Europe; ${ }^{1}$ but it so happened that in England all the political power of the estates became in time vested in two chambers." One of them, the House of Lords, contained the whole body of peers, who were the successors of the great feudal vassals of the crown; while the other, the House of Commons, was composed of the deputies from the towns and counties, who had gradually consolidated into a single house, and might be said to represent all the people who were not peers.

By degrees the House of Commons acquired the right of originating all bills for raising or spending money, and hence its support became essential to the crown. But its members were seli-reliant, and on the whole less open to court influence than the peers. They felt under no obligation to support the policy of the government, or to vote an appropriation unless they understood and approved the purpose for which it was to be used; and King William III, during his wars with France, found them by no means as easy to manage as he could wish. Hitherto his ministers had been selected from both political parties, and hence were not in harmony with each other, and were unable to exert an effective influence in Parliament; but between I69.3 and I 696 he dismissed the Tories, and confided all the

1 Thus in France, and in most continental countries, there were three, while in Sweden there were four: the clergy, the nobles, the cities, and the peasants. The existence of only tro Houses in England might almost be called an accident. (C.. Freeman, Growth of the English Constitution, p. 93-)

: In I664 Convocation, which was the ecclesiastical chamber, discontinued the practice of voting separate taxes on the clergy, and thus the clergy definitely ceased to be an estate of the realm. (See Hallam, Const. Hist. of England, ch. xvi.) 
great offices of state to the Whigs, who had a majority in the Commons. The result was that the House which had been turbulent became docile; and the ministers by winning its confidence were able to guide it, and obtain the appropriations that were required. This was the origin of the practice of selecting the ministers from the leaders of the majority in Parliament - a practice which at a later time crystallized into a principle of the British constitution. ${ }^{1}$ But of course men who held the most important offices, and at the same time led the House of Commons, were certain not to be mere tools in the hands of the king. They were sure to try to carry out their own policy, and when the sceptre of William had passed into the hands of the first two Georges, who were foreigners and took little interest in English politics, the ministers exercised the royal power as they pleased, and became in fact the custodians of the prerogatives of the crown. The subordination of the king to his ministers is, indeed, the inevitable result of the system; for so long as the latter retain their influence over the House, and can direct its votes, they can hold their offices and administer them according to their own views. If the king attempts to dismiss them they can block the wheels of government, by inducing Parliament to withhold supplies; and if, on the other hand, they cease to be the leaders of the House, and a different party with new leaders gets a majority, the king finds himself obliged to send for these and entrust the government to them. The system which had been devised in order that the king might control the House of Commons became, therefore, the means by which the House of Commons, through its leaders, controlled the king, and thus all the power of the House of Commons and of the crown became vested in the same men, who

1 Macaulay, History of England, ch. xx. 
guided legislation and took charge of the administration at the same time.

The House of Lords, meanwhile, was losing ground. It had no right to initiate or amend money bills, and, what was far more important, it had no influence on the formation or the policy of the cabinet. The ministers were, indeed, often peers, but they were not selected because they belonged to the majority in the House of Lords, nor did they resign when that body voted against them. Like their colleagues from the other House, they represented the majority in the Commons, and were solidly in accord with it. The House of Lords, therefore, found itself confronted by the combined power of the crown and the House of Commons, and this it was unable to resist. In fact the power to create new peers furnished the crown, or rather the ministers acting in its name, with a weapon always ready to break an obstinate resistance; and at the time of the Reform Bill of $\mathrm{I}_{32}$ a threat of this kind was enough to compel submission. The upper house thus gradually lost authority, and when it attempted to exert it again on the plea that it was reserving questions for the decision of the people, it was shorn of much of its power by the Act of rgrr.

The ministers remain in office only so long as they continue to be the leaders of the lower house and are able to control the majority. When this condition has changed, a vote is sometimes passed to the effect that the ministers have ceased to possess the confidence of the House; but such an express declaration is rarely used at the present day; and a hostile vote on any matter of considerable importance is treated as a proof that the government has no longer the support of a majority. After such a vote, therefore, the ministers resign, and if there is a normal division 
into two parties the crown sends for the leader of the Opposition, and entrusts him with the formation of a cabinet. The defeated ministers have, however, one other alternative. If they think that the House of Commons has ceased to be in harmony witl the opinion of the nation, they can dissolve Parliament in the name of the crown, and try the chance of a new election. Thus in the English parliamentary system the direction of the legislature, and the control of the executive, is in the hands of the leaders of the majority in the House of Commons. For their exercise of power these leaders are directly responsible to the House of Commons, which can call them to account at any time; while the House itself is responsible to the people, which gives its verdict whenever the end of the term of Parliament or a dissolution brings about a general election.

\section{Parliamentary Government on the Continent}

Turning now from the consideration of English forms of government to those in use on the Continent, we find that the main features of the British constitution have been very generally imitated. In fact, the plan of two chambersone of which issues from an extended suffrage and has the primary control of the purse, and of a cabinet whose members appear in the chambers and are jointly responsible to the more popular one, resigning on an adverse votehas spread widely over Europe. These features of the parliamentary system are striking, and have become famous, while the procedure in the House of Commons, which enables the system to work smoothly, has attracted far less attention, and has been followed very little. This is peculiarly true of France, where the principle of cabinet responsibility has been adopted to the fullest extent, but where there exist at the same time several practices that help to 
twist parliamentary government out of the British form. More curious still is the fact that these very practices have been blindly copied by other countries which intended to imitate the English system.

A description of the French government must begin with its structure, with the legal composition and powers of the different political bodies. This will occupy the present chapter. In the next, the actual working of the system will be considered, especially in regard to the character of political parties; and an attempt will be made to explain the peculiarities that are found by a reference to the condition of the people, and to those parts of the political machinery that seem to have a marked effect. In other words, we shall begin with the skeleton, and then take up the muscles and nerves.

\section{The French Constitution}

The first thing one looks for in a modern government is the constitution; but although the French Republic has a written constitution, it differs in two very important respects from those to which we are accustomed. It is not comprised in any one document, but in a series of distinct laws, and it contains few provisions limiting the functions of the different bodies, or prescribing fundamental rights which the state is enjoined to respect. This is a departure not only from American, but also from the earlier French usage, for previous constitutions in France have been long documents and have contained elaborate bills of rights; although the absence of practical guarantees has made their effectiveness depend upon the good pleasure of the government. The present constitution is very different, and barely provides for the organization of the powers of the state, without even speaking of such important matters as a yearly budget or the tenure of office of the judges. It does 
little more than establish the main framework of the government by declaring what the chief organs of public life shall be, leaving them almost entirely free to exercise their authority as they see fit. The reason for such a departure from French traditions is to be found in the circumstances of the case. The earlier constitutions in France were attempts to frame an ideal system, but the present one resulted from an immediate need of providing a regular government of some sort that could rule the country for the time, and it was drawn up by men who had no belief in its inherent perfection. To understand this it is necessary to glance at the history of the period.

\section{Hislory of its Creation}

The rapid series of defeats suffered by the French armies at the hands of the Germans, in 1870 , destroyed the tottering authority of the Emperor, and when the news of the surrender of Napoleon III at Sedan reached Paris an insurrection broke out on the fourth of September. A republic was at once proclaimed; but this was no time to debate plans for a constitution, and so long as the war lasted the country was ruled by the self-elected Government of the National Defense. When the war was over, a National Assembly with indefinite powers was chosen by universal suffrage. The member of this body who commanded the most general public confidence was Thiers, the historian, and former minister of Louis Philippe. To him the Assembly entrusted the executive power, and in August, I87 I, it gave him the title of President, without, however, fixing any term for the duration of the office. Thiers was constantly urged to introduce the parliamentary system by allowing his ministers to assume the responsibility for his acts, but this he refused to do, saying that the position in 
which it would place him, although perfectly consistent with the dignity of an hereditary king, was for him, a little bourgeois, entirely out of the question. ${ }^{1}$ He held himself, however, personally responsible to the Assembly for the conduct of his government, took part in the debates on the measures he proposed, and declared that he was ready to resign at any time, if the majority wanted him to do so.? This state of things continued for nearly two years, when a hostile vote forced Thiers to retire. His successor, Marshal MacMahon, was elected for a term of seven years, and as the new President was not a member of the Assembly, his cabinet became responsible in the parliamentary sense. But although the chief magistrate now held office for a fixed period, and was freed from the caprices of an uncertain majority, still there was no constitution and no permanent organization of the government. The situation was, in fact, a provisional one, prolonged abnormally by the strange condition of politics. The monarchists formed a majority of the Assembly, but they were hopelessly divided into two sections - the Legitimists, whose candidate was the Comte de Chambord, and the Orleanists, who followed the Comte de Paris. At one moment it seemed not impossible that the Comte de Chambord might become king, and some of his supporters opened negotiations for the purpose; but these were brought to nothing by obstinacy of the prince himself, who was a true scion of his race, and would not yield one jot of his pretensions. He even

1 The law of Aug. 3I, I87I, declared that the President as well as the ministers should be responsible to the Assembly. See Dupriez, Les Ministres dans les Principaux Pay's d'Europe el d'A mérique, ii. 320.

2 The law of March I 3, I $_{73}$, abolished the right of the President to take part in debate, and while allowing him to address the Assembly, ordered the sitting to be suspended immediately after his speech. This was, of course, an attempt to reduce the personal influence of Thiers. (Dupriez, ii. 321-322.) 
refused to accept the tricolor flag that means so much to Frenchmen, and clung doggedly to the ancient white standard of his house.

\section{The Constitutional Laws}

Under such circumstances a monarchy was out of the question, and so this assembly of monarchists at last set to work to organize a republic; or, rather, a sufficient number of monarchists, feeling that a republic was, for the time at least, inevitable, joined with the minority to establish a government on the only basis possible. ${ }^{1}$ But although the republican form was adopted, the institutions that were set up departed essentially from the ideas which the French had been accustomed to associate with that term. The present government, like all political systems that have been created suddenly and have proved lasting, was essentially a compromise. From the French republican principles there was borrowed, besides the name, little more than the election of the chief magistrate, while from the traditions of constitutional monarchy were taken the irresponsibility of the head of the state, and the existence of a second legislative chamber. ${ }^{2}$ Now it was natural that no one should feel inclined to construct an ideal system on a hybrid foundation of this kind. Moreover none of the parties regarded the work of the Assembly as final, for the monarchists looked forward to a future restoration of the

1 Very good brief descriptions of the formation of the Constitution may be found in Bozérian's Elude sur la Rérision de la Constitution, and in Professor Currier's Constitulional and Organic Laws of France. The latter, published as a supplement to the Annals of the Amcrican Academy of Political Science (March, I893), gives a translation into English of all these laws. See also an article by Saleilles on the "Development of the Present Constitution of France." (Ann. Amer. Acad. of Pol. Sci., July, I895.)

2Lebon, Frankreich (in Marquardsen's Handbuch des Oeffentlichen Rechts), p. 19. 
throne, while their adversaries hoped to place the Republic before long on a more secure and permanent footing. Hence the Assembly did no more than provide for the immediate organization of the government in as brief and practical a manner as possible. It passed three constitutional laws, as they are called, which are in the form of ordinary statutes, and very short and concise. One of them, that of February 25 , I875, provides for the organization of the powers of the state. Another, that of February 24, I875, deals in greater detail with the organization of the Senate. And the third, dated July I6, I875, fixes the relations of the powers of the state among themselves.

\section{Amendments}

The provisional character of the constitution is clearly seen in the method of amendment. It has been the habit in France to make a sharp distinction between the constituent and legislative powers, the former being withdrawn to a greater or less extent from the control of the Parliament. But in this instance both of the great parties wanted to facilitate changes in the fundamental laws, in order to be able to carry out their own plans whenever a favorable occasion might present itself. ${ }^{1}$ A departure from tradition was therefore made, and it was provided that the constitutional laws could be amended by a National Assembly, or congress, composed of the two branches of Parliament sitting together, which should meet for this purpose whenever both chambers on their own motion, or on that of the President of the Republic, declared the need of revision.2

${ }^{1}$ Cf. Borgeaud, Etablissement et Révision des Constilutions, pt. iii, liv. ii, ch. viii.

${ }^{2}$ Const. Law of Feb. 25, I875, Art. 8. It is not provided whether the Chambers shall declare in general terms that there is a need of revision, or shall specify the revision to be made, and this point has given rise to lively 
The constitutional laws have been twice amended in this way. On the first occasion (June 21, 1879), the provision making Versailles the capital was repealed, and thereupon a statute was passed transferring the seat of government to Paris. ${ }^{1}$ On the second occasion (August 14, 1884), several amendments were made. Among these one of the most notable changed the provisions relating to the mode of electing senators, and another declared that the republican form of government cannot be made the subject of a proposal for revision - the object of the latter being to prevent the destruction of the Republic by constitutional means. The device of providing that a law shall never be repealed is an old one, but I am not aware that it has ever been of any avail.

This method of amendment has virtually rendered the Parliament omnipotent; for, excepting the provision about changing the republican form of government, there is no restriction on its authority. The chambers cannot, it is true, pass an amendment to the constitutional laws in the form of an ordinary statute, but if they are agreed they can pass it by meeting as a National Assembly. The power of the chambers is therefore nearly as absolute as that of the British Parliament. ${ }^{2}$ The principle, moreover, that the fundamental law cannot be changed by ordinary statute is devoid of legal sanction, for if the chambers should choose to pass an act of this kind, no court or official could legally prevent its application. ${ }^{3}$ But while the constitution

debates; but on the two occasions when a revision was actually undertaken, the Chambers passed identical resolutions specifying the articles to be amended. (Lebon, Frankreich, pp. 74, 75; Saleilles, op. cil., pp. 6, 7, 9.)

1 Law of July 22, 1879 . This act provides, however, that the National Assembly shall meet at Versailles.

${ }^{3}$ Cf. Saleilles, op. cit., p. I I.

${ }^{3}$ Cf. Laferrière, Traile de la Jurisdiction Administrative, i. 5. 
imposes no legal restraint on the Parliament, it would be a great mistake to suppose that it has no effect. On the contrary, it has such moral force that any attempt to pass a statute that clearly violated its terms would awake a strong repugnance; and indeed a suggestion by the president of one or other of the chambers that a bill would be unconstitutional has more than once sufficed to prevent its introduction. ${ }^{1}$ On the other hand, the fact that formal amendments can be made only in joint session, and only after both chambers have resolved that there is a need of revision, has some influence in preventing changes in the text of the constitutional laws, because the Senate, being the more conservative body, and only half as large as the other House, is timid about going into joint session, not knowing what radical amendments may be proposed there, and fearing to be swamped by the votes of the deputies.

Let us now examine the organs of the state in succession, taking up first the Parliament with its two branches, the Senate and the Chamber of Deputies; then turning to the President as the chief magistrate of the Republic, and finally passing to the ministers as the connecting link between the Parliament and the President, and the controlling factor in the machinery of the state.

\section{The Chamber of Deputies}

The composition of the Chamber of Deputies is left to ordinary legislation, except that the constitutional law of February 25, I875, Art. I, provides for its election by universal suffrage. By statute the ballot is secret, and the franchise extends to all men over twenty-one years of age who have not been deprived of the right to vote in consequence of a conviction for crime, and who are not bank-

1 Lebon, Frankreich, p. 23. 
rupts, under guardianship, or in active military or naval service. ${ }^{1}$ 'To be eligible a candidate must be twenty-five years old and not disqualified from being a voter. ${ }^{2}$ Members of families that have ever reigned in France are, however, excluded; ${ }^{3}$ and in order to prevent as far as possible the use of pressure the law forbids almost every state official to be a candidate in a district where his position might enable him to influence the election. ${ }^{4}$ As a further safeguard against the power of the administration, which is justly dreaded by the French Liberals, it is provided that all public servants who receive salaries, except a few of the highest in rank, shall lose their offices if they accept an election to Parliament, and that a deputy who is appointed even to one of these highest offices, unless it be that of minister or undersecretary, shall lose his seat. ${ }^{5}$

The Chamber of Deputies is elected for four years, and consists at present of six hundred and two members; ten of the seats being distributed among the various colonies, and six allotted to Algiers, while the remaining deputies are chosen in France.

\section{Scrutin de Lisle and Scrutin d'Arrondissement}

The method of election has varied from time to time between that of single electoral districts, a system called the scrutin d'arrondissement, and that of the scrutin de liste, which consists in the choice of all the deputies from each department on a general ticket; the difference being the same

1 Arts. 1, 2, and 5 of the Law of Nov. 30,1875 . Poudra et Pierre, Droil Parlementaire, $\$ \$ 482-484,498-514$.

2 Law of Nov. 30,1875 , Arts. 6,7 .

${ }^{3}$ Law of June 16,1885 , Art. 4.

- Law of Nov. 30,1875 , Art. I2.

'Id., Arts. 8, 9, and Ir. A deputy appointed to one of these offices may, however, be reëlected (Art. Ir). 
that exists between our method of electing congressmen each in a separate district, and our method of choosing presidential electors on a single ticket for the whole state. The scrutin d'arrondissement or single district system prevailed from 1876 to 1885 , when the scrutin de liste was revived; ${ }^{1}$ partly, no doubt, in order to swamp the reactionary minority, but also with the hope of withdrawing the deputies from the pressure of petty local interests, which had become lamentably strong, of getting a chamber of broader and more national views, and of forming a republican majority that would be more truly a great and united party. The experiment did not last long enough to produce any sensible effect of this kind; and indeed the change seems, on the whole, to have resulted in an increase of the power of the local politicians, who formed themselves into nominating and electoral committees for the department. At the general elections of 1885 the Reactionaries gained rather than lost seats in spite of the scrutin de liste; and the disgust of the Republicans with the device from which they had hoped so much was brought to its height two or three years later by General Boulanger. This singular man - who, after enjoying a marvelous popularity, became in a short time an object of contempt, if not of ridicule - had been minister of war in one of the recent republican cabinets. He was forced to resign on account of his enormous expenditure on the army, and the fear that he would plunge the nation into a war with Germany. He then posed as the savior of the country; and, being at the height of his reputation, he made use of the scrutin de liste to hold a plébiscite or popular vote of France piecemeal. Whenever a seat became vacant in a department he stood as a candidate; and if elected he held the seat only until a vacancy occurred 1 Law of June $16,1885$. 
in another department, when he resigned to appear as a candidate again. After doing this in several large departments he was able to declare that a considerable part of the French people had pronounced themselves for him a procceding which would have been impossible if the deputies had been elected in five hundred and seventy-six separate districts. His success at the by-elections had so frightened the Republicans that they restored the scrutin d'arrondissement, or single electoral districts, before the general clection of 1889 took place. ${ }^{1}$

\section{The Chamber a Tumulluous Body}

Every large body of men, not under strict military discipline, has lurking in it the traits of a mob, and is liable to occasional outbreaks when the spirit of disorder becomes epidemic; but the French Chamber of Deputies is especially tumultuous, and, in times of great excitement, somctimes breaks into a veritable uproar. Even the method of preserving order lacks the decorum and dignity that one expects in a legislative assembly. The President has power to call a refractory member to order and impose a penalty in case he persists; but instead of relying on this alone, he often tries to enforce silence by caustic remarks. The writer remembers being in the Chamber when $\mathrm{M}$. Floquet was presiding - the same man who had fought a duel with General Boulanger and wounded him in the throat. A

I Law of Feb. 13, 1889. In order to frustrate more effectually Boulanger's scheme, a law of July i 7, I 889, provided that no one should be candidate in more than one district. The meaning and effects of these laws is discussed by Saleilles (Ann. Am. Acad. Pol. Sci., July, I 895, pp. 19-37). A measure providing for the restoration of the scrutin de liste with an arrangement for proportional representation passed the Chamber of Deputies in I9I2, but was rejected by the Senate in the following March. For the arguments in its favor, see "Electoral Reform in France," by J. W. Garner, American Political Science Review', vii. 610-638 (Nov., 1913). 
deputy who had just been speaking kept interrupting the member who was addressing the Chamber, and when called to order made some remark about parliamentary practice. The President cried out, "It is not according to parliamentary practice for one man to speak all the time." "I am not speaking all the time," said the deputy. "At this moment you are overbearing everybody," answered the President. This incident is related, not as being unusual or humorous, but as a fair sample of what was constantly occurring in the Chamber. Even real sarcasm does not seem to be thought improper. Thus in a later debate a deputy, in the midst of an unusually long speech, was continually interrupted, when the President, Floquet, exclaimed, "Pray be silent, gentlemen. The member who is speaking has never before approached so near to the question." I These sallies from the chair are an old tradition in France, although, of course, their use depends on the personal character of the President. One does not, for example, find them at all in the reports of debates during the time Casimir-Perier was presiding over the Chamber. When the confusion gets beyond all control, and the President is at his wits' end, he puts on his hat; and, if this does not quell the disturbance, he suspends the sitting for an hour in order to give time for the excitement to subside.

\section{The Senate}

The French Senate consists of three hundred members; and, by the constitutional law of February 24, 1875, two hundred and twenty-five of these were to be elected for nine years by the departments, while seventy-five were appointed for life by the same National Assembly that framed that law. The life senators were intended to be a perma- 
nent feature of the Senate, and it was provided that when any one of them died his successor should be elected for life by the Senate itself. A few years later, however, the Republicans, thinking such an institution inconsistent with democracy, passed the amendment to the constitutional laws, to which a reference has already been made. ${ }^{1}$ This, while leaving untouched the provisions relating to the existence and powers of the Senate, took away the constitutional character from those regulating the election of senators, which thus became subject to change by ordinary legislation. A statute was then passed (December 9, r884) providing that as fast as the life senators died their seats should be distributed among the departments, so that at present all the senators are elected in the same way. There are eighty-six departments in France, and by the act the senators are apportioned among them according to population. Life senatorships having been abolished, the number of seats belonging to a department varies from two up to ten, while the territory of Belfort, each of the three departments of Algiers, and several of the colonies, are represented by one senator apiece. ${ }^{3}$ The senators so elected hold office for nine years, one third retiring every three years. ${ }^{3}$ They are chosen in each department of France by an electoral college composed of the deputies, of the members of the general council, of the members of the councils of the arrondissements, and of delegates chosen by the municipal councils of the communes." Before I884 each commune elected only one delegate, ${ }^{5}$ but by the law of that year the number of delegates increases with the size of the communes, though much less than in proportion to the population. These

1 Const. Law of Aug. I4, 1884.

- Law of Dec. 9, I884, Art. 2.

- Const. Law of Feb. 24, r875, Art. 4.
3 Id., Art. 7.

I Id., Art. 6. 
communal delegates form a large majority of the electoral college, and hence the Senate was called by Gambetta the Great Council of the Communes of France. ${ }^{1}$

A senator must be forty years old; and since the law of I 884 the disqualifications for this office have been the same as for that of member of the Chamber of Deputies. ${ }^{2}$

\section{Its Functions}

The legislative power of the Senate and the Chamber of Deputies is the same, except that financial bills must originate in the latter; ${ }^{3}$ but while it is admitted that the Senate may reduce proposals for taxes and appropriations, there is a dispute whether it can increase them or not, and debates on this point are constantly recurring. In practice the Chamber has sometimes accepted augmentations thus introduced, but more frequently the Senate has abandoned them. ${ }^{4}$ The Senate has two peculiar functions. First, its consent is necessary for a dissolution of the Chamber of Deputies, ${ }^{5}$ a provision designed as a safeguard against the President, for fear that he might dissolve the Chamber in order to attempt a coup d'état during its absence; and, second, the President is authorized, with the approval of the Council of Ministers, to constitute the Senate a high court to try any one for an attempt on the safety of the state. ${ }^{6}$ This power has been used more than once, notably in the case of General Boulanger, who failed to appear for trial, and was condemned in his absence.

${ }^{1}$ Saleilles, $o p$. cit., p. $4 \mathrm{I}$.

${ }^{2}$ Law of Dec. 9, 1884, Arts. 4, 5, and Provisions Temporaires. Law of Dec. 26, 1887. Lebon, Frankreich, pp. 63, 64, 67.

${ }^{3}$ Const. Law of Feb. 24, 1875, Art. 8.

4 Dupriez, ii. 430-432. 5 Const. Law of Feb. 25 , 1875, Art. 5.

6 Lebon, Frankreich, p. 73, Const. Laws of Feb. 24, 1875, Art. 9, and July 16, I875, Art. 12. The procedure was regulated by a law of Aug. 10, 


\section{Its Actual Influence}

With such an organization and powers, an American might suppose that the Senate would be a more influential body than the Chamber of Deputies; but in reality it is by far the weaker body of the two, although it contains at least as much political ability and experience as the other house, and, indeed, has as much dignity, and is composed of as impressive a group of men as can be found in any legislative chamber the world over. The fact is that according to the traditions of the parliamentary system the cabinet is responsible only to the more popular branch of the legislature, and in almost every instance where a cabinet in France has resigned on an adverse vote of the Senate, the vote was rather an excuse for the withdrawal of a discredited ministry than the cause of its resignation. ${ }^{1}$ A case, which occurred during the year 1896 , is the only one where the responsibility of the ministers to the Senate was fairly raised, and where anything like a real contest took place

I889. By the Const. Law of July I6, 1875, Art. I2, the Chamber of Deputies can impeach the ministers, and in case of high treason the President of the Republic. The impeachments are tried by the Senate. For the interpretation put upon this clause, see Lebon, Frankrcich, pp. 55-58.

1 Dupriez (ii. 453-454) mentions two such cases. One in 1876 , when the cabinet, disliking a bill for an amnesty passed by the Chamber of Deputies, proposed in the Senate a compromise, which the latter, averse to any amnesty, rejected. The ministers thereupon resigned, but they had really been beaten in the Chamber of Deputies, and their only hope of restoring their prestige lay in forcing through the compromise. The other case was in 1890 , when the Senate, by a vote condemning the economic policy of the government, brought about a cabinet crisis. But the ministry was already divided within itself, and had almost broken in pieces a few days before. There appears to have been a third instance of the same kind in 1883 . In that case the Fallières ministry resigned because the Senate rejected a bill on the expulsion of members of families that had reigned in France, but here again the cabinet was disunited and in a feeble condition before the vote in the Senate took place. (Journal Officiel, Feb. I 8 and 19, 1883.) 
between the chambers. On this occasion the Senate did certainly force a united and vigorous cabinet to resign, but it was enabled to do so only because the majority in the Chamber of Deputies was highly precarious, for there can be no doubt that if the cabinet could have relied on the hearty support of the Chamber it would have defied the Senate as it had already done two months before. ${ }^{1}$ It has

1 The history of this case may be summarized as follows: The Chamber of Deputies when elected contained a decided majority of Conservative Republicans, and for two years the successive cabinets represented their views, but by degrees the party became disintegrated, and in October, I 895 , a Radical cabinet was formed, which succeeded in obtaining the support of a majority. Early in the new year the Minister of Justice, not being satisfied that the Juge d'Instruction, who was holding the inquest on the southern railroad frauds, was sufficiently zealous in discovering the offenders, took the case out of his hands and entrusted it to another magistrate. On February i , the Senate, which was strongly conservative, passed a vote censuring this act as an interference with the course of justice. Two days later, the Chamber of Deputies expressed its confidence in the government; whereupon the Senate, on February 15, repeated its former vote. On the 2oth, the matter was again brought up in the Chamber of Deputies, and M. Bourgeois, the head of the cabinet, declared that he should not resign so long as he was upheld by the Chamber, which proceeded to reaffirm its vote of the week before. A number of the senators who had been opposed to the cabinet, finding that it would not yield, read in the Senate next day a declaration protesting against the refusal of the ministers to hold themselves responsible to the Senate as a violation of the Constitution, but saying that while as senators they reserved their constitutional right, they did not wish to suspend the legislative life of the country. The Senate thereupon adopted an order of the day approving this declaration, and thus virtually. gave up for a time the attempt to make the ministers responsible to itself. (Journal Officiel, Feb. 12, 14, 16, 21, and 22, 1896.)

A little later the cabinet brought forward a bill for a progressive income tax, and succeeded on March 26 in getting the Chamber to adopt an order of the day approving of the general principle involved. The order, however, which was somewhat equivocal, was only carried by sixteen votes, and more than half of the deputies were believed to be opposed in their hearts to the tax. The Senate thought its opportunity had come, and again passed a vote of lack of confidence in the ministry, this time on the subject of foreign affairs. (Journal Officiel, April 4.) The result was no better than 
been only in very exceptional cases, that the upper house has upset the ministry. Moreover the question at issue in the struggle of 1896 was not whether the cabinet is responsible to the Senate to the same extent that it is to the other chamber, but simply whether the Scnate can insist on the removal of a ministry to which it is peculiarly hostile. No one has ever doubted that under ordinary circumstances the ministers are responsible only to the Chamber of Deputies. The majority in that body alone is considered in the formation of a cabinet, and an unfavorable vote there on any current matter of importance is followed by a change of ministers, while a similar vote in the Senate is not regarded as a reason for resignation. ${ }^{1}$

before, but the Senate felt the strength of its position, and was not to be ignored. On April 2I, therefore, it took a bolder step by a resolution to postpone the vote on the credits asked for Madagascar "until it had before it a constitutional ministry having the confidence of the two Chambers." Instead of trying to continue the fight Bourgeois resigned, declaring to the Chamber of Deputies that as the representative of universal suffrage it ought to be supreme, but that, owing to the impossibility of insuring proper military service in Madagascar after the vote of the Senate, patriotism obliged him to withdraw. The Radicals in the Chamber succeeded in carrying a vote affirming once more the preponderance of the elect of universal suffrage, and urging the need of democratic reforms; but a few days later a purely Conservative cabinet presented itself to the Chamber, and obtained a vote of confidence by a majority of forty-three. (Journal Officiel, April 22, 24, and May 1.)

The outcome of the affair justified the belief that the Chamber would not have engaged in a prolonged struggle to support the cabinet; that while unwilling to turn the ministers out itself, it was not sorry to have the Senate do so. Had the deputies been so thoroughly in earnest as to force a deadlock between the Chambers, the Senate could not have refused its consent to a dissolution, and would certainly have been obliged to give way if the elections had resulted in a victory for the cabinet.

1 Since this was written the Briand ministry resigned on a vote in the Senate in 1913. A bill to reëstablish scrutin de liste with a provision for proportional representation was passed by the Chamber of Deputies in July, I9I2. It was not debated in the Senate for a long time, and not until after a change of ministry. The new Premier declared that he should treat 
As a rule the Senate does not decide the fate of the ministries, and hence cannot control their policy. The result is that without sinking to the helplessness of the English House of Lords, it has become a body of secondary importance. ${ }^{1}$ At one time it stood very low in public esteem, on account of its origin; for it was created by the Reactionaries in the National Assembly, and was regarded as a monarchical institution; and even after the greater part of its seats were occupied by Republicans, it was suspected of being only half-heartedly in favor of the republican form of government. Its condemnation of Boulanger increased its popularity by making it appear a real bulwark of the republic against the would-be dictator; but the prejudice against it has by no means disappeared, and the extreme Radicals have never ceased to demand its abolition, although conservative feeling in France will doubtless remain strong enough to prevent such a step. How great the influence of the Senate will be in the future is not easy to foretell. Some people were of opinion that with life members gone, many of whom had been distinguished in letters, in science, or in war, it would lose a good deal of its prestige. To some extent this fear has been realized. But, on the other hand, men of mark are still elected, and now that the Senate is not afraid of being thought lukewarm or hostile to the republic, and does not feel its existence seriously threatened, it has acquired more boldness and energy. ${ }^{2}$ the adoption of the bill as a question of confidence, and when the Senate on March 18 voted against proportional representation, he resigned. His action caused surprise, and the reasons for it are somewhat obscure.

1 In his Essays on Government (ch. I) the writer has tried to prove that this must necessarily be the condition of one of two chambers wherever the cabinet is responsible to the other; and that the cabinet cannot in the long run be responsible to both.

2 Dupriez, ii. $382-383$. The present position and the probable future of the Senate are discussed by Saleilles, op. cit., pp. 37-52. 
It is highly improbable, moreover, that it will become utterly powerless, so long as the deputies are divided into a number of political groups and the ministers are not able to speak with authority as the leaders of a great and united party.

Although the Senate has little or no share in directing the policy of the cabinet, it must not be supposed that it is a useless body. On the contrary, it does very valuable work in correcting the over-hasty legislation of the other chamber, and in case of disagreement often has its own way or effects a compromise. ${ }^{1}$

The two chambers meeting in joint session form what is called the National Assembly, which, as we have seen, has power to revise the constitutional laws. It has one other function, that of electing the President of the Republic.

\section{The President of the Republic}

This officer is chosen for seven years, and is reëligible; the only limit on the choice of a candidate being found in the constitutional law of August 14, I884, ${ }^{2}$ which excludes all members of families that have ever reigned in France-a provision dictated by the fear that, like Napoleon III, a prince might use the presidency as a step to the throne. The President is at the head of a republic, but he lives and travels in a style that is almost regal, for the conception of a republic as severe, simple, and economical has changed very much in France since the Second Empire taught the nation extravagance. ${ }^{3}$

The duties of the President, like those of every chief magistrate, are manifold. He is the executive head of the

1 Dupriez, ii. 4I3-4I5.

2 Const. Law of Feb. 25,1875 , Art. 2.

3 Cf. G. Channes, Nos Fautes, Letter of Jan., I885; Theodore Stanton in the Arena, Oct., I89x. 
nation, and as such executes the laws, issues ordinances, ${ }^{1}$ and appoints all the officers of the government. ${ }^{2} \mathrm{He}$ has also certain functions of a legislative character, but, except for the right of initiative in legislation, these are not in fact very extensive. He has no veto upon the laws, and although he may require the chambers to reconsider a bill, the right has never been exercised. ${ }^{3}$ With the consent of the Senate he can dissolve the Chamber of Deputies, ${ }^{4}$ but this power has also fallen into disuse, because the members of his cabinet are very much under the control of the deputies, who dread the risk and expense of an election; and, in fact, a dissolution has not taken place since President MacMahon's unsuccessful attempt to use it in 1877 as a means of getting a chamber in sympathy with his views. The President has power to make treaties; but treaties of peace, of commerce, those which burden the finances, affect the persons or property of French citizens in foreign countries, or which change the territory of France (in other words, all the more important ones), require the ratification of the chambers. ${ }^{5}$ A declaration of war also requires their consent; ${ }^{6}$ but as a matter of fact the government managed to wage war in Tunis and Tonquin without any such consent, alleging at first that the affair was not a war, and afterwards defending itself on the ground that the Parliament by voting credits had virtually sanctioned its course. ${ }^{7}$

1 For the nature of this power, see infra.

2 Const. Law of Feb. 25,1875 , Art. 3.

3 Const. Law of July I6, I 875, Art. 7; Dupriez, ii. 369 . It is not likely to be used unless after the bill has passed the cabinet that favored it has resigned, and another hostile to it has come in.

" Const. Law of Feb. 25, 1875, Art. 5.

- Const. Law of July 16, I875, Art. 8.

B Id., Art. 9.

; See Lebon, Frankreich, pp. 46, 47. 


\section{His Personal Authority}

Unlike the President of the United States, the French President is not free to use his powers according to his own judgment, for in order to make him independent of the fate of cabinets, and at the same time to prevent his personal power from becoming too great, the constitutional laws declare that he shall not be responsible for his official conduct, except in case of high treason, and that all his acts of every kind, to be valid, must be countersigned by one of the ministers; ${ }^{1}$ and thus, like the British monarch, he has been put under guardianship and can do no wrong. When, therefore, we speak of the powers of the President, it must be remembered that these are really exercised by the ministers, who are responsible to the Chamber of Deputies. The President, indeed, is not usually present at the cabinet consultations (conseils de cabinet) in which the real policy of the government is discussed, and as a rule he presides only over the formal meetings (conseils des ministres) held for certain purposes specified by law. ${ }^{2}$ He has power, it is true, to select the ministers, and in this matter he can use his own discretion to some extent, but in fact he generally entrusts some one with the formation of a cabinet, and appoints the ministers this man suggests. ${ }^{3}$ His duty in these cases is not, however, as simple as that of the English King, because, for reasons that will be discussed in the next chapter, there is usually on the fall of a cabinet no leader of a victorious opposition to whom he can turn. A good deal of tact and skill is sometimes required at cabinet crises, and

1 Const. Law of Feb. 25, 1875 , Arts. 3 and 6.

${ }^{2}$ Lebon, Frankreich, p. 53; Dupriez, ii. $350-35 \mathrm{I}$ and $367-368$, states that the President is often present when important matters are discussed, but cannot influence the decision.

3 Dupriez, ii. 340. 
it is said that on one occasion the formation of a ministry was due to the personal influence of President Carnot. ${ }^{1}$

Sir Henry Maine makes merry over the exalted office and lack of power of the President. "There is," he says, "no living functionary who occupies a more pitiable position than a French President. The old kings of France reigned and governed. The Constitutional King, according to M. Thiers, reigns, but does not govern. The President of the United States governs, but he does not reign. It has been reserved for the President of the French Republic neither to reign nor yet to govern." 2

At first sight the situation does, indeed, appear somewhat irrational. When the head of the state is designated by the accident of birth it is not unnatural to make of him an idol, and appoint a high priest to speak in his name; but when he is carefully selected as the man most fit for the place, it seems a trifle illogical to entrust the duties of the office to some one else. By the constitution of Sieyès an ornamental post of a similar character was prepared for the First Consul, but Napoleon said he had no mind to play the part of a pig kept to fatten. In government, however, the most logical system is not always the best, and the anomalous position of the President has saved France from the danger of his trying to make himself a dictator, while the fact that he is independent of the changing moods of the chambers has given to the Republic a dignity and stability it had never enjoyed before. It is a curious commentary on the nature of human ambition, that in spite of the small power actually wielded by the President in France, the presidential fever seems to have nearly as strong a hold on public men as in this country.

${ }^{1}$ See "France under M. Constans," in Murray's Magazine for May, I8go.

2 Popular Government, p. 250. 


\section{The Conseil d'Etat}

Before proceeding to consider the ministers, there is one other institution which claims attention on account of its past rather than its present position. This is the Conseil d'Etat or Council of State, ${ }^{1}$ a body whose importance has varied a great deal at different times. Under Napoleon I, and again during the Second Empire, in addition to the possession of executive functions, it was a real source of legislation; while at the time of the Restoration and the Monarchy of July it became what it is to-day, a council with high attributes, but very little authority. Except as a court of administrative justice, ${ }^{2}$ it has now lost most of its influence; for, although it must be consulted before certain classes of ordinances can be issued, and may be consulted on other administrative matters, its advice need never be followed; and in fact the habit of consulting it is said to have become little more than a mere form. ${ }^{3}$ The legislative functions of the Council have faded even more completely to a shadow, as is proved by the fact that while the government or either of the chambers may seek its aid in the framing of statutes, the privilege is rarely exercised by the ministers, scarcely at all by the Senate, and never by the Chamber of Deputies.

The members of the Council are divided into several classes, but those belonging to the most important class,

1 Aucoc, Conférences sur le Droit Adm., liv. ii, ch. i, \$ 3; Ducrocq, Cours de Droit Adm., tit. i, ch. i, sec. i, § iii; Bœurf, Résumé sur le Droil Adm., ed. of r 895, p. 32 et seq.; cf. Lebon, Frankreich, pp. 96-98; Dupriez, ii. 285-316, passim, and pp. 481-492; Goodnow, Comparative Administrative Lâ", i. Iо7-II3. See also articles entitled "Le Conseil d'Etat et les Projets de Réforme," by Varagnac, Revue des Deux. Mondes, Aug. I5 and Sept. I 5,1892 .

${ }^{2}$ For its functions of this nature, see infra.

3 "La Réforme Administrative - La Justice," by Vicomte d'Avenel, Revue des Deux Mondes, June I, I889, pp. 597-598. 
and the only ones who can vote when the Council sits as a court, are appointed and dismissed at will by the President of the Republic. ${ }^{2}$

\section{The Ministers}

In a parliamentary system the ministers have two distinct functions. One of these is the same as that of the members of the President's Cabinet in the United States, and consists of the management of the departments of the administration. The other is the duty of representing the government in the legislature, urging the adoption of its measures, and defending its policy against the attacks of its adversaries. These two functions are not necessarily united; and, in fact, it has been a common habit in some countries to appoint ministers without portfolios, as it is called, that is, without any executive duties at all, in order that they may devote their whole energy to the battles in Parliament. ${ }^{1}$ Although there is nothing to prevent such a practice in France, it is not followed to-day, each minister being at the head of a particular branch of the administration. The number of departments, however, and the distribution of the public business among them, is not fixed by law, but is regulated from time to time by decree of the President of the Republic. The number of ministers is, therefore, constantly liable to change according to the immediate needs of the public service. Before the war, there were twelve departments or ministries: those of the Interior; of Justice; of Foreign Affairs; of Finance; of War;

1 The other members are appointed by the President subject to certain conditions, but as he can dismiss any of them, their tenure of office depends on the pleasure of the cabinet, and in fact by means of resignations or removals, most of the councilors were changed in 1879 in order to make the council Republican. - "Le Conseil d'Etat," Varagnac, Revue des Deux Mondes, Sept. I5, I892, p. 295. 
of the Navy; of Education and the Fine Arts; of Public Works; of Labor; of Commerce, Industry, and Post and Telegraphs; of Agriculture; and of the Colonies. ${ }^{1}$

\section{Their Responsibility to the Chambers}

The constitutional law of February 25, is 75 (Art. 6), declares that the ministers are collectively responsible to the chambers for the general policy of the government, and individually for their personal acts. The object of this clause was, of course, to establish the parliamentary system, and in fact the French ministry is responsible to the Chamber of Deputies, as the English is to the House of Commons, and resigns on a hostile vote on any matter of importance. Except, indeed, for the Ministers of War and of the Navy, who are usually military men, the cabinet officers are almost always selected from among the members of Parliament, although the reason for this practice in England does not apply in France, because the ministers have a right to be present and speak in either chamber, whether members of it or not.?

\section{Their Enormous Poier}

But in order to understand fully the position of the French ministers, and their relation to the Parliament, it is necessary to realize their enormous power, and this is due largely to three causes - the paternal nature of the government, the centralization of the state, and the possession by the

1 This practice virtually exists in England, because some of the offices held by the ministers, such as that of First Lord of the Treasury, and that of Chancellor of the Duchy of Lancaster, involve little or no administrative duties.

2 Const. Law of July $16,18_{75}$, Art. 6. In practice this privilege is also accorded to their undersecretaries. Lebon, Frankreich, p. 52. 
executive of authority that in an Anglo-Saxon country would be lodged with the legislature or the courts of law.

On the first of these matters, the paternal nature of the government, there is no need to dwell at length. All governments are growing more paternal at the present day, for a reaction has set in against the extreme laissez-faire doctrines preached by Adam Smith, John Stuart Mill, and the English political economists of the earlier school. There is a general tendency to restrain the liberty of the individual and subject him to governmental supervision and control. Such control and supervision are traditional in France, and far exceed anything to which we are accustomed in this country. All trades and occupations are there subject to a great deal more police inspection than with us. They require more generally to be licensed, and are regulated and prohibited by the administrative officials with a much freer hand. And although the liberty of the press and the right of holding public meetings have been substantially realized under the republic, the right of association was very limited until the law of July I, IgOI, for no society of more than twenty persons, except business companies and associations of persons pursuing the same profession or trade, could be formed without the permission of the Minister of the Interior or the prefect of the department. ${ }^{1}$ It is easy to see how much power all this paternalism places in the hands of the administration.

\section{Local Government}

An explanation of the centralization of the state entails a brief survey of local government; and here we meet with a deeply rooted French tradition, for centralization was ${ }^{1}$ Lebon, Frankreich, pp. 32-39; Ducrocq, tit. ii, ch. iii; ch. iv, 8 iii. 
already great under the old régime, and although the first effect of the Revolution was to place the administration of local affairs under the control of independent elected bodies, the pressure of foreign war, and the necessity of maintaining order at home, soon threw despotic power into the hands of the national government. Under Napoleon this power became crystallized in a permanent form, and an administrative system was established, more perfect, more effective, and at the same time more centralized than that which had existed under the monarchy. ${ }^{1}$ The outward form of the Napoleonic system has been continuously preserved with surprisingly little change, but since 1830 its spirit has been modified in two distinct ways: first, by means of what the French call deconcentration, that is, by giving to the local agents of the central government a greater right of independent action, so that they are more free from the direct tutelage of the ministers; second, by a process of true decentralization, or the introduction of the elective principle into local government, and the extension of the powers of the local representative bodies. But although the successive rulers of France have pursued this policy rather steadily, the progress of local self-government has been far from rapid. ${ }^{2}$ One reason for this is the habit of looking to the central authorities for guidance in all matters. Another is a fear on the part of the government of furnishing its enemies with rallying-points which might be used to organize an opposition - a fear that takes shape to-day in pro-

1 For a short but vigorous comment on Napoleon's system, see G. L. Dickinson, Revolution and Reaclion in Modern France, ch. ii.

2 On the subject of local government, I have used Aucoc, Conférences, 3 d ed.; Bœuf, Résumé, ed. of I 895; Leroy-Beaulieu, Adm. Locale en France et en Anglelerre; Lebon's two works on France; Goodnow, Comp. Adm. Lau. There is a popular account in Block, Entretiens familiers sur l'Adm. de notre pays. 
visions forbidding the local elected councils to express any opinions on general politics, or to communicate with each other except about certain matters specified by law. A third cause of the feeble state of local self-government is to be found in the fact that the Revolution of 1789 destroyed all the existing local divisions except the commune, and replaced them by artificial districts which have never developed any great vitality, so that the commune is the only true centre of local life in the republic. ${ }^{1}$ A fourth, and perhaps the most potent cause of all, is the dread of disorder which has been constantly present in the minds of Frenchmen, and has made them crave a master strong enough to cope with any outbreak.

\section{The Prefect}

France is divided into eighty-six departments, at the head of each of which is a prefect, appointed and removed at pleasure by the President of the Republic, but in reality nominated by the Minister of the Interior. The office is, indeed, regarded as distinctly political, and the incumbent is often replaced when the minister changes. The prefect, who is by far the most important of the local officials, occupies a double position, for he is the agent of the central government in regard to those matters of general administration which are thought to concern the whole country, and at the same time he is the executive officer of the department for local affairs. In the former capacity he is in theory the immediate subordinate of the Minister of the Interior, but since his duties extend to all branches of the administration, he corresponds in practice directly with any minister in whose sphere of action the matter with which he is called

1 Most of the existing communes were in fact created in 1789 . 
upon to deal may lie. His authority as the agent of the central government is not, however, the same in all cases. Sometimes he is absolutely subject to the orders of the ministers. This is true when he executes general laws and ordinances; but when, for example, he directs the police of the department, or supervises the subordinate local bodies, he proceeds on his own responsibility, and his acts can be overruled by the central government only in case they are contrary to law, or give rise to complaints on the part of the persons affected by them. In pursuance of the policy of deconcentration, the prefect has been given an independent authority of this kind over a large number of subjects; and he was intended to exercise his own judgment in regard to them, but the influence and pressure of the deputies has, it is said, induced him to shirk responsibility as much as possible by referring doubtful questions to the ministers, and hence the centralization has not been diminished as much as was expected. ${ }^{1}$ In matters of general administration, the prefect is assisted by a prefectorial council of three or four members appointed by the President of the Republic; but, except when it sits as an administrative court, the functions of this body are almost altogether advisory, and their use has become scarcely more than a form. ${ }^{2}$

\section{The General Council}

As the executive officer for local affairs, the prefect carries out the resolutions of the General Council. This is the representative assembly of the department, and is elected by universal suffrage, one of the members being chosen in

1 Channes, Letter of October I, I884.

2 Vicomte d'Avenel, "La Réforme Adninistrative," Revue des Deux Mondes, June I, x889, p. 596. 
each canton for six years, and half of them being renewed every three years. The authority of the body is jealously limited. Its competence is almost entirely confined to affairs that are deemed to have a strictly local interest, ${ }^{1}$ and even in regard to these its powers are not absolute, for its votes on certain matters can be annulled by the President of the Republic, and its budget, that is the annual tax levy and list of appropriations, is not valid without his approval. Although the Council has the right of final decision in a considerable class of subjects, its actual power over them is curtailed in a variety of ways. In the first place it does not carry out its own votes, but their execution is entrusted to an agent of the central government, the prefect, who appoints all the officials, manages the public institutions, and signs the orders for all payments of money; the direct control of the council over his performance of these duties extending only to the election of a standing commission which has little more than a right of inspection. ${ }^{2}$ In the second place, the prefect has an opportunity to exert a great deal of influence over the action of the Council, for not only has he a right to address it, but he prepares the budget and all other business, and in fact it is not allowed to act on any matter until it has heard his report. ${ }^{3}$ Moreover, the Council is only permitted to sit a very short time. It has two regular sessions a year, whose duration is limited, one to a month, the other to a fortnight; and although extra sessions can be held they must not exceed one week apiece.

1 Its functions in relation to the general administration consist in apportioning certain direct taxes, in giving its advice when asked, and in expressing its wishes on matters not connected with general politics.

2 The Council can delegate to this commission a somewhat indefinite class of functions, but it is not in fact a body of much importance. Dupriez, ii. $467-468$.

Aucoc, p. 282. 
Finally its very existence is insecure, for it can be dissolved by the chief of the state. In general it may be said that in matters falling within its province the General Council cannot do everything it wants, but can prevent almost anything it does not want. Its financial resources are not large, ${ }^{1}$ and its attention is confined for the most part to the construction of roads, subventions to railroads, and the care of schools, insane asylums, and other institutions of a similar character.

At one time a hope was entertained that politics might be kept out of the general councils, but it has not been fulfilled, the departmental elections being regularly conducted on party lines. ${ }^{2}$ It has therefore been thought best to entrust the supervision of the communes largely to the central government and its representative the prefect, rather than to the councils with their partisan bias, and this, of course, deprives the latter of a part of the importance they would otherwise possess. ${ }^{3}$

\section{The Arrondissement and the Canton}

The next local division is the arrondissement. This is a mere administrative district without corporate personality, with no property, revenues, or expenses of its own, and although it has a subprefect and an elected council, neither of them has much power. In fact it has been proposed to abolish the arrondissement altogether.

1 Almost its only source of revenue is the addition of a limited sum to the direct state taxes.

${ }^{2}$ Bozérian, in his Etude sur la Révision de la Constitution (pp. 89-9o), attributes this to the fact that the local assemblies take part in the election of senators.

${ }^{3}$ By the law of 1884 on municipalities, part of the supervision over these bodies, which had previously been in the hands of the general councils, was withdrawn and given to the prefect. 
The canton, which is the next subdivision, is really a judicial and military rather than an administrative district, and therefore does not concern us here.

\section{The Commune}

We now come to the communes, which are the smallest local entities, but differ enormously in area and population. They vary in size from twenty acres to over a quarter of a million, and they run all the way from a hamlet with a dozen inhabitants to large cities; yet with the exception of Paris, Lyons, and Marseilles they are all governed on one plan. The officer in the commune whose position corresponds to that of the prefect in the department is the mayor. He acts in the same way both as agent of the central government, and as the executive head of the district, but whereas in the prefect the former character predominates, the mayor is chiefly occupied with local matters. It is largely for this reason that, unlike the prefect, he is not appointed by the President, but since 1884 has been elected by and from the communal council for the length of its own term. ${ }^{1}$ The mayor is, however, by no means free from control. So far as he acts as agent of the central government, he is absolutely under the orders of the prefect. Nor is this all. The subject of communal police, which includes the public health and other matters of a kindred nature, is considered a part of the local administration, but the acts of the mayor in regard to it can be annulled by the prefect, who has also power in many cases to issue direct orders of his own. Moreover the police officials require to be confirmed by the prefect, ${ }^{2}$ and can be removed only by him. ${ }^{3}$

1 The office is an honorary one, as the mayor receives no salary.

2 Or sub-prefect.

${ }^{3}$ The mayor is not free from control in regard to other matters of local interest, for his accounts must be submitted for approval to the prefect, 
But even these extensive powers of control are not deemed enough, and it is provided that the mayor can be suspended from office for a month by the prefect, or for three months by the Minister of the Interior, and can be removed altogether by the President of the Republic.

The deliberative organ of the commune is the communal council, which varies in size from ten to thirty-six members, and is elected by universal suffrage for four years. Its authority extends to all communal affairs, except that it has nothing to do with the broad subject of police, although that is regarded for other purposes as a local matter. The statute on municipal government lays down the general principle that the decisions of the council on local affairs, when legally made, are conclusive without the approval of any superior administrative official, but in a subsequent section all the most important matters are specially excepted from the rule. The list of exceptions includes almost every financial measure, the construction of roads and buildings, and the sale of communal property. ${ }^{1}$ The council has, therefore, very much less power than might at first be supposed; and in order to guard against any attempt on its part to exceed these slender privileges, the prefect is given a discretionary authority to suspend it for a month, while the President of the Republic can dissolve it entirely and appoint a commission with limited powers to rule the commune for two months, when a new election must take place.

As in England, so also in France, much of the work of local administration is done by, and much of the credit therefor is due to, permanent officials little seen by the public; who can order the payment of any expense properly authorized if the mayor neglects to make it.

1 The official who has power to approve the budget can also inscribe therein certain obligatory expenses. 
and chief among them to the secretary of the mayor, who in small communes is apt to be the village schoolmaster also. ${ }^{1}$

\section{Paris}

The general laws of local government already described do not, however, cover the whole field, because a dread of the explosive character and communistic tendencies of the democracy of Paris has prevented the capital from enjoying even the measure of liberty granted to other towns. The city has, indeed, a municipal council composed of eighty elected members and endowed with most of the usual powers and a general council for the department with limited powers, composed of these same eighty reinforced by eight suburban members; but the executive authority is entirely in the hands of the central government. It is lodged in part with the mayors of the twenty arrondissements, who are appointed directly by the President of the Republic; but chiefly with two prefects appointed in the same way. One of these, the Prefect of the Seine, has most of the functions of the ordinary prefect, together with those of a central mayor; while the other, the Prefect of Police, has charge of the police, and is directly responsible to the Minister of the Interior.'

This sketch of local government in France shows how centralized the state still remains, what extensive supervision and control the administration keeps in its own hands, and how slight is the measure of real local autonomy, if measured by an Anglo-Saxon standard. In fact, the cen-

1 The Goiernments of European Cities, pp. 86-87, 90.

2 In Lyons the control of the police is still entrusted to the Prefect of the Rhone; in Marseilles it is in charge of the Prefect of the Bouches-du-Rhône. In all cities of over 40,000 people the organization of the police is fixed by decree of the chief of the state, although the members of the force are appointed as in other communes. 
tral government still makes itself continually and actively felt in local affairs, and this is for the ministers a great source of power, but also, as we shall see later, a cause of weakness.

\section{Legislative Powers of the Executive}

A third source of the enormous power of the ministers in France is the possession by the executive of authority that in an Anglo-Saxon country would be lodged with the legislature or the courts of law. This requires an explanation, for it involves some of the most interesting peculiarities of French, and, indeed, of continental political ideas.

\section{Decrees and Ordinances}

Let us take first the legislative authority of the executive in France. When an English or an American legislator drafts a statute he tries to cover all questions that can possibly arise. He goes into details and describes minutely the operation of the act, in order that every conceivable case may be expressly and distinctly provided for. He does this because there is no one who has power to remedy defects that may subsequently appear. If the law is vague or obscure, it can receive an authoritative interpretation only from the courts by the slow process of litigation. If it is incomplete, it must remain so until amended by a subsequent enactment. In some cases, it is true, an officer or board is given by statute power to make regulations. The Local Government Board and our boards of health furnish examples of this; but such cases are exceptional, and most Anglo-Saxons feel that the power is in its nature arbitrary, and ought not to be extended farther than is necessary. And here it is important to distinguish between rules issued by the head of a department for the guidance of his subordi- 
nates and the regulations of which we are speaking. The former are merely directions given to the officials for the purpose of instructing them in their duties, and are binding on no one else. The right to issue them must belong, to some extent, to every one who has other persons under his orders, although they are used much more systematically in France than in the United States. The regulations with which we are concerned here are of quite a different kind, for they are binding on all citizens who may be affected by them, and have, in fact, the character of laws.

In America the authority to make regulations is delegated by the legislature cautiously, and apart from such an express delegation no officer of the government has power to issue any ordinances with the force of law. But in France all this is very different. Statutes that do not concern the rights of a man against his neighbor, that do not, in other words, form a part of the Civil Code, are often couched in general terms, and enunciate a principle which the executive is to carry out in detail. ${ }^{1}$ Sometimes the President of the Republic is expressly given power to make regulations, but even without any special authority he has a general power to make them for the purpose of completing the statutes, by virtue of his general duty to execute the laws. ${ }^{2}$ Such regulations in France are called acts of secondary legislation, and the ordinances of the President in which they are contained are termed décrets. The power to make them is not, however, confined to the chief of the state.

1 Dupriez (ii. 377), after remarking this difference between English and French legislation, expresses a regret that the French Parliament has shown a tendency of late years to go more into details.

2 On the power to issue ordinances in France, see Aucoc, Conférences, $\S \S 52-57,66,91$, I70; Ducrocq, Cours, $\$$ 6I-66, 72-73, 109-110, 210-214; Goodnow, i. $85-87$. Before issuing certain classes of ordinances the President must consult the Council of State, but he is not obliged to follow its advice. 
For matters of inferior gravity the laws often confer a similar authority on the ministers, the prefects, and even the mayors, and in this case the edicts are termed arrêtés, to distinguish them from the more solemn ordinances of the President. ${ }^{1}$ The regulations cannot, of course, be contrary to law, or in excess of the authority of the official who issues them. If they are so, and infringe private rights, a process to have them annulled may be instituted before the administrative courts, and in certain limited cases the ordinary courts can also refuse to apply them. ${ }^{2}$

\section{Appropriations}

So much for the power of the executive to make law, but this does not exhaust its encroachments on what we have learned to regard as the province of the legislature, for it is less strictly held to the appropriations voted by the chambers than is the case with us. The virements (that is to say, the use for one purpose of appropriations voted for another), which were an abuse under the Empire, have, indeed, been abolished, except as between different items in the same chapter of the annual budget; but certain chapters are designated each year to which additions can be made by decree of the President issued with the consent of the council of ministers. Moreover, in urgent and unforeseen cases arising when Parliament is not in session, the government has power by means of such a decree, not only to incur the expenses called for by the emergency, but also to open an extraordinary credit on its own authority and borrow the money that it needs. ${ }^{3}$

${ }^{1}$ Lebon, Frankreich, p. 23; Aucoc, Ducrocq, ubi cit.

${ }^{2}$ Laferrière, Traitê de la Jur. Adm., liv. iii, ch. i, sec. ii; liv. vi; liv. vii, ch. i, sec. iv.

${ }^{3}$ In both cases notice of the decree must be laid before the Chambers within fourteen days from their next meeting. (Lebon, Frankreich, p. 162.) 


\section{Judicial Powers of the Executive}

One may, perhaps, be pardoned for dwelling at somewhat greater length on the judicial powers of the executive in France, both because they are so little understood by English-speaking people, and because their origin may be traced to a tradition which has its roots far back in the past.

The characteristic difference between the political history of England and that of France is to be found in the fact that the English, though influenced by each new spirit of the age, have never yielded entirely to its guidance, while the French have always thrown themselves into the current, and, adopting completely the dominant ideas of the time, have carried them to their logical results. Thus, in the Middle Ages, the feudal system never became fully developed in England as it did in France. Again, when absolute monarchy came into vogue, the British sovereign was not able to acquire the arbitrary power of the Bourbons. And, lastly, democracy made its way neither so rapidly nor so thoroughly on the north as on the south of the Channel. The result is that in France the institutions of any period have been adapted almost exclusively to the wants of the time in which they were produced, and in the succeeding age it has been thought necessary to destroy them and devise new ones more in harmony with the new conditions; ${ }^{1}$

It is worth while, moreover, to note in passing that there is no effective process for bringing to account a minister who exceeds the appropriations. He can, indeed, be impeached, but except in times of great excitement this would not be done if the money had been expended for public purposes; and as regards civil liability, there is no court that has power to compel him to refund the sums which he has spent illegally.

1 This is the more striking because the French are in some ways more conservative than the English, as, for examplc, in their retention to the present day of nominally public exccutions. M. Lebon truly remarks (France as It Is, p. 86): "Pcople have no idea of the spirit of routine and conservatism which prevails in France." 
whereas in England there has been no need of such sweeping changes, and it has been possible to preserve in a modified form many of the most important features of the government. Hence the permanence and continuity of the political system. ${ }^{1}$ Let us inquire how these facts have affected the development of judicial and administrative institutions in the two countries.

\section{Early Royal Power in England}

The Norman kings of England strove deliberately to check the growth of the feudal system, and their successors constantly followed the same policy. Now the essence of the feudal system consisted in the blending of public and private law by making all political relations depend on the tenure of land; and, in fact, according to the strict feudal theory, no man had direct relations with any superior except his immediate overlord. Every great vassal of the crown, therefore, had jurisdiction over all the tenants on his estate, which he exercised by holding a court of his own for the administration of justice among them.

\section{The Judicial System in England}

The English kings resisted this principle, and tried to bring their power to bear directly on all the people of the realm. For this purpose sheriffs were appointed to represent the crown in the counties, and what was of more permanent importance, the gravest crimes, actions for the possession of land, and subsequently other matters, were brought within the jurisdiction of the Curia Regis. ${ }^{2}$ As early as the reign of Henry I, moreover, royal officers were commissioned

1 Cf. Freeman, Growth of the English Constitution, pp. 63-66.

2 See Pollock \& Maitland, History of English Lai', vol. i. 85-8\%, and chs. $v$ and vi. 
to travel about the country holding court, a practice which was renewed in a more systematic form by Henry II, and has continued with short interruptions to the present day. ${ }^{1}$ The chief object of the early kings in sending out the itinerant justices, as they were called, was no doubt financial; for their duties consisted in assessing taxes, collecting fines for violation of the law, and administering justice, which was in itself a source of no small profit in the Middle Ages. ${ }^{2}$ The functions of the justices in the collection of revenue grew, however, less and less prominent, but their administration of justice became of permanent importance, and in regard to this two tendencies were at work. In the first place, the royal judges adopted new methods of procedure and gradually developed the trial by jury, while the baronial courts clung to the ordeal and other barbaric forms of trial. " "The gladsome light of jurisprudence," as Coke called it, came with the king's courts, and hence it is not surprising that they supplanted the baronial courts, and in time drew before themselves all the important lawsuits. In the second place, the commissions which had at first been issued to high officials, barons, and knights, became confined to regular judges, and about the time of Edward I were given only to the members of the royal courts at Westminster. ${ }^{4}$ The same body of judges, therefore, ex-

1 The institution of traveling judges was not new. It had been used by Charlemagne (Hallam, .Middle Ages, ch. ii, part ii. 5), and a similar practice was employed by Alfred, Edgar, and Canute (Stubbs, History of England,

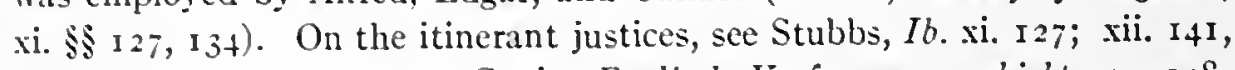
I 45 , I50; xiii. I 63 ; xv. 235; Gneist, Englische Verfassungsgeschichte, pp. I4 $\mathrm{S}$, 224-22S, 305 (note), 31 S-319, 447. Pollock \& Maitland, i. I34, I49, I79; Franqueville, Le Systime Imliciaire de la Grande Bretagn!e, i. I 49 et seq. The royal duty of sending the justices in eyre is one of those insisted upon in Magna Charta, $\$$ is.
2 Stubbs, $I b$., xi. 127.
${ }^{3}$ Cf. Stubbs, Ib., xiii. I6.4 Gneist, Ib., P. I 42 .
- Gneist, Ib., p. 3IS; Stubbs, Ib., xv. 235 . 
pounded the law in all parts of the realm; and hence England, alone among the countries of Europe, developed it uniform national justice called the common law. ${ }^{1}$ The people naturally became attached to this law and boasted of the rights of Englishmen, while the courts that were the creators and guardians of the law became strong and respected.

\section{The Administrative System}

The very fact that the judicial branch of the government became so highly developed made the centralization of the administration unnecessary. At the time when the itinerant justices first went on circuit, administration in the modern sense was of course unknown, and such local affairs as needed attention were regulated by the shire moots and other local meetings. ${ }^{2}$ The sheriff, indeed, represented the crown; but his powers were curtailed more and more, until, apart from his command of the military forces of the county, he became little more than an officer of the courts. ${ }^{3}$ When the local administration grew more important, it was confided not to him, but to justices of the peace, who, though nominally selected by the king, were never strictly under his orders, and in time became almost completely independent, except for the purely judicial control exercised by the Court of King's Bench. ${ }^{4}$

\section{The Royal Power in France}

In England, therefore, the royal power came carly into contact with the people all over the kingdom by means of

${ }^{1}$ Cf. Hallam, Middle Ages, ch. viii, part ii. 3 .

2 Stubbs, Ib., xv. 205.

${ }^{3}$ On the powers of the sheriff, see Stubbs, Ib., xiii. $163, x v \cdot 204-207$; Gneist, $I b$., pp. I1 $15-120,297$.

- Gneist, Ib., pp. 298 el seq., 468 et seq. 
the courts of law, and the judicial system became highly centralized; while the local administrative institutions developed slowly, and through them the king's authority was little felt. In France, the course of events was very different, for the royal power came into direct contact with the people at a much later date, and therefore in quite another form.

\section{The Judicial System in France}

When the feudal system became established, the great vassals set up their own courts and succeeded in excluding the royal judges from their fiefs, so that the direct jurisdiction of the crown became confined to the comparatively small part of the country which was included in the royal domain. Gradually, indeed, as the feudal system began to lose its strength, the king's jurisdiction encroached upon that of the vassals - a process which was carried on both by insisting on the right of appeal to the royal tribunals, and by reserving for the exclusive cognizance of the king's courts a somewhat indefinite class of cases known by the name of cas royaux. ${ }^{1}$ But this process aroused serious resistance on the part of the territorial lords, and it was not until the sixteenth century that the crown judges possessed the universal authority they had obtained in England more than three hundred years earlier. So strong, in fact, did the local jealousy of the Parliament of Paris (the king's high court of justice) remain, that after the great fiefs fell into the hands of the crown, they were not placed under the jurisdiction of that tribunal, but were given independent

1 Aubert, Le Parlement de Paris de Phillippe le Bel a Charles VII, ch. i, sec. i; Ifist. du Parl. de Paris, I250-1515, liv. ii, ch. i; Du Bois, IIist. du Droit Criminel de la France, part. i, ch. i; Esmein, Ifist. du Droit Français, part i, tit. ii, ch. i; Hist. de la Proc. Crim., part i, tit. i, ch. i, sec. ii; ch. ii, sec. i; Hallam, Middle Ages, ch. ii, pt. ii. 5 . 
parliaments of their own.' At the outbreak of the Revolution there were thirteen separate parliaments, so that every considerable province had a distinct body of tribunals.2 Under these circumstances, the courts could not create a uniform national justice like the English common law, and although since the revolution such a uniform system has been provided by the Code, this does not strengthen the hands of the judges, but has rather the opposite tendency. In the first place, it is not their work, and hence does not redound to their glory; and secondly, by weakening the force of precedent, it diminishes the importance of judicial decisions. This review of the history of the courts of law shows clearly why they have not attained in France the same power and authority as in Anglo-Saxon countries. ${ }^{3}$

\section{The Administrative System}

The French courts of law were weak because the royal authority did not come into direct contact with the people at the time when public and private law were everywhere blended, when the tone of thought was peculiarly legal, and when political power was chiefly exercised in a judicial or semi-judicial form. ${ }^{4}$ It made itself felt at a later date, and especially as the restorer of order after the anarchy caused by the Hundred Years' War. Its presence brought peace and prosperity, and naturally enough the organs which it employed acquired a high degree of vigor. Now, at this period,

1 Du Bois, pt. i, ch. ii. § 2; Bastard d'Estang. Les Parlements de France, i. 36-38; Esmein, Hist. du Droil Français, tit. ii, ch. i, sec. i, § 2, v.

2 For the dates of the creation of the provincial parliaments, which run from 1444 to 1775 , see Bastard d'Estang, i. I89, note, and Esmein, ubi supra.

3 Since the Revolution, the courts have, of course, been reorganized on a centralized basis.

1 On the relative importance attributed to law in the Middle Ages, and in later times, see Stubbs' chapters on the Characteristic Differences between Medixval and Modern History, in his Lectures on Mcd. and Mod. Hist. 
administration, in the modern sense, was becoming important, and as the royal authority came to be exercised by commissioners or intendants, who had, indeed, certain judicial powers, but whose functions were chiefly administrative, ${ }^{1}$ the administration developed an influence and a strength which the courts had never attained. The administrative system became centralized, and grew to be the most important factor in the government. ${ }^{2}$ All classes of the people looked to it for protection; ${ }^{3}$ in fact, it took, to a great extent, the place which the judiciary filled in England and in those countries which had inherited the English principles.

\section{Doctrine of the Separation of Powers}

This difference in the relative authority of the courts and the administration was intensified - so far as the United States and France were concerned - by the political philosophy of the last century. Montesquieu, in his "Spirit of the Laws," proclaimed the importance of separating the executive, legislative, and judicial powers, and the maxim was eagerly accepted on both sides of the Atlantic, though in very different senses. Our ancestors, anxious to maintain the independence of the courts and the sacredness of private rights, took the principle to signify the necessity of so protecting the courts from the control or influence of the other branches of the government that they might be free to administer justice without regard to the official position of the litigants or the nature of the questions involved. They meant to preserve the English tradition that there is only one law of the land to which every one is subject, from the

${ }^{1}$ Chéruel, Dic. des Inst. de la France, "Intendants des Provinces"; Esmein, IIist. du Droit Français tit. ii, ch. v, § 2.

${ }^{2}$ Cf. De Tocqueville, An. Reg. et la Rev., liv. ii, chs. ii, iii.

${ }^{3}$ De Tocqueville speaks of all classes as looking on the government as a special providence. Id., ch. vi (7th ed. pp. 100-103). 
humblest citizen to the highest officer. The French, on the other hand, had acquired no great passion for law, or for the rights of the individual, and did not admit a claim on the part of any one to delay or overturn the public interests in order to get his own grievances redressed. Moreover, they had seen the Parliament of Paris interfere with the government by refusing to register the edicts of the king; for although this tribunal had failed to acquire judicial supremacy, it had retained a good deal of political power, which it used during the years preceding the Revolution to resist innovations. ${ }^{1}$ Such a power might not be disliked as a means of opposing an unpopular court party, but it could not be tolerated for a moment when the reins of government were seized by men who believed themselves commissioned to reform the world. The French statesmen, therefore, took Montesquieu's doctrine in the sense that the administration ought to be free to act for the public weal without let or hindrance from the courts of law. The Declaration of the Rights of Man proclaimed in 1789 that a community in which the separation of powers was not established had no constitution; and a statute of the next year, on the organization of the tribunals, gave effect to the maxim as it was understood in France by providing that the judges should not interfere in any way with the work of administrative authorities, or proceed against the officers of the government on account of their official acts. ${ }^{2}$ The American and French applications of the doctrine of the separation of powers are both perfectly logical, but are based on different conceptions of the nature of law. The Anglo-Saxon draws no distinction between public and private law. To him all legal rights and duties of every kind form part of one uni-

1 Cf. Edward J. Lowell, The Eve of the French Revolution, p. 105.

${ }^{2}$ Aucoc, Conférences, part i, liv. i, ch. i; Bœuf, Résumé, part iv, sec. ii. 
versal system of positive law, and so far as the functions of public officials are not regulated by that law, they are purely matters of discretion. It follows that every legal question, whether it involves the power of a public officer or the construction of a private contract, comes before the ordinary courts. ${ }^{1}$ In France, and in the other states of continental Europe, private law, or the regulation of the rights and duties of individuals among themselves, is treated as only one branch of jurisprudence; while public law, which deals with the principles of government and the relations of individuals to the state, is regarded as something of an entirely different kind. Of course every civilized government must strive to treat all its subjects fairly, and hence, in the course of administration, questions of justice must arise; but as these do not concern the rights of a man against his neighbor they are not classed in France with private law. It is felt that, unlike questions of private law, they ought not to be decided solely by the application of abstract principles of justice between man and man, but must be considered from the broad standpoint of public policy. Now the domain of the ordinary French courts is private law alone, and it is quite logical to regard any attempt on their part to judge administrative acts and thus pass on questions of public policy, as an attempt to go beyond their proper sphere of action and invade the province of the executive.2

The principle of withdrawing questions of public law from the ordinary courts was not new. It existed in prac-

1 This principle, like all others in Anglo-Saxon countries, is not carried out with absolute consistency. 'Thus the various commissions in America on railroads, interstate commerce, etc., partake of the nature of the French administrative tribunals.

2 The French, like the Americans, have not applied their principles quite strictly, for Criminal Law ought to be a branch of Public Law (Aucoc, Introd., $\S_{1}$ ), but it has been put into the charge of the ordinary courts. 
tice under the old régime, ${ }^{1}$ but was extended and systematized after the Revolution. The protection of officials from suit or prosecution was formally incorporated into the Constitution of the year VIII ( 1799 ), and remained in force until after the fall of Napoleon III, when it was repealed by a decree of the Government of the National Defense. ${ }^{2}$ This decree was intended to remove all hindrances in the way of bringing government officials before the ordinary courts, but it had very little effect, because the Tribunal of Conflicts held that it applied only to the personal protection of officials, and did not affect the principle of the separation of powers, which, as understood in France, forbids the ordinary judges to pass upon the legality of official acts. $^{3}$

\section{The Administrative Courts}

Questions of this kind, therefore, are still reserved exclusively for the administrative courts - tribunals created especially for this purpose, and composed of officials in the service of the government. Criminal cases are, indeed, an exception to the rule, ${ }^{4}$ but this is of no great practical importance, because as force is very sure to be on the side of the police, it is no real protection to the individual to know that he cannot be condemned for resistance; and on the other hand the officials concerned run no risk of punishment for illegal acts committed in obedience to orders, be-

1 See Laferrière, Traité, liv. i; De Tocquevillc, An. Reg. et la Rev., book ii, ch. iv; Varagnac, "Le Conseil d'Etat," Revue des Deux Mondes, Aug. I 5, I892.

${ }^{2}$ Decree of Sept. I9, I870.

'Arrêt, 30 Juillet, I873, "Affaire Pélétier," Dalloz, Jur. Gen., I874, part iii, p. 5; Laferrière, Traité, liv. iii, ch. vii; Aucoc, Conf., liv. v, ch. ii; Goodnow, Comp. Adm. Law, ii. 172-1 76 .

- Laferrière, Traité, liv. iii, ch. vi. But cven this exception is not absolute. See, also, a discussion of the subject in Dalloz, I88I, part iii, p. I7, note. 
cause the government can easily manage to prevent their being brought to trial, and can pardon them if convicted. In France, therefore, there is one law for the citizen and another for the public official, and thus the executive is really independent of the judiciary. Nor is the danger of interference on the part of the administrative tribunals as great as it would be in the case of the ordinary judges, because the former can be controlled absolutely in case of necessity; and, in fact, they are so much a part of the administration itself that they fall into the province of the Interior and not that of Justice. ${ }^{1}$ The independence of the ordinary judges is secured by a provision which prevents their removal or transfer to another court, without the approval of the Court of Cassation, the final court of error. But the judges of the administrative courts enjoy no such protection, and can be removed by the President at any time. ${ }^{2}$ The result is that, although a great mass of administrative law has slowly grown up from the decisions of these courts ${ }^{3}$ and personal liberty is much more respected than

1 It would be absurd to suppose that the government always extorts a favorable judgment. This was clearly shown in 1895 , in a once famous case, which illustrates at the same time the degree of respect entertained for the decisions of the administrative courts. The Minister of the Interior and the railroads disagreed about the interpretation of a statute relating to the state guarantee of interest on the securities of the roads. The matter was brought before the Council of State, which decided in favor of the railroad. Thereupon the Minister of the Interior resigned, but the rest of the cabinet felt bound to abide by the decision. A discussion was, however, raised in the Chamber of Deputies, which in effect censured the ministers for submitting the matter to the Council of State, and thereby caused the cabinet to resign.

${ }^{2}$ Aucoc, Conf., i. 156-157; Bœuf, Résumé, pp. 39-40. The members of the Council of State who are qualified to sit as administrative judges are said to be always selected from the political friends of the government (Dupriez, Les Minisires, ii. 482-483).

${ }^{3}$ Unlike the civil law, the administrative law has never been codified, and indeed it could not be without destroying the element of discretion 
under the Empire, yet the courts themselves cannot be considered entirely judicial bodies, and are far from providing the rights of the citizen with a complete guarantee, at least where political questions are involved. ${ }^{1}$

which is the reason for its existence. So far as it is not contained in statutes and ordinances, it has developed, like the English Common Law, by decision and precedent, and hence the sources for studying it are the reported cases and the writings of jurists such as those heretofore cited.

1 Lebon, France as It Is, pp. IOI-IO2; Goodnow (Comp. Administrative Law, ii. 220-22I, 23I) remarks that the administrative courts have shown themselves more favorable to private rights than the ordinary courts, and in some ways that is certainly true. In English-speaking countries a public official can be prosecuted criminally or sued for damages in the ordinary courts for any acts done without legal authority, whether his action was in the public interest or not. But he is not, as a rule, liable for acts authorized by law although his actual motives were bad or his diseretionary powers misused. Nor is he usually liable for negligence in the performanee of his duties. The state, on the other hand, cannot in theory be sued at all. In practice some means of maintaining claims against the state is almost always provided; but only for breaches of contract or to recover property, not for torts committed by officials.

In France acts of officials are elassified in quite another way with very different results. First, there are personal acts, which involve grave personal misconduct or gross negligence on the part of the official, whether beyond or within his legal authority. For these, and these alone, he is liable in damages in the ordinary courts. Whatever he does in good faith for the public interest, whether within or beyond his legal authority, is an act of administration for which a remedy, if any, can be sought only against the state, and as a rule only in the administrative courts. Acts of this kind fall into three classes, called actes de gestion, actes d'authoritê and actes de gouvernement. Broadly speaking, actes de gestion are acts done in the course of the regular administration of the public services, and the administrative courts tend to award compensation against the statc for acts of this nature, not only when done wholly without legal authority, but also when there has been an abuse of that authority for improper purposes, or even negligence, as, for example, where a merchantman has been damaged by collision with a warship. (See a discussion of this whole subject in Hauriou, La Gestion Administrative.) Actes d'authorite are donc in the exercise of the right of the state to issue commands to its citizens; and if such commands, orders or regulations are issued without legal authority, or involve an abuse of power, they' can be annulled by a special procedure in the Council of State, which may 
It is not quite accurate to say that the ordinary courts can consider the validity of no official act; and, indeed, the line between the jurisdiction of the ordinary and the administrative courts does not follow any strictly logical principle. ' Questions of indirect taxes, for example, and those relating to the lesser highways (petite voirie), come before the ordinary courts, while those arising under the direct taxes, or relating to the greater highways (grande voirie), come before the administrative tribunals. The competence of the various administrative courts is no less complicated. The prefect and the mayor have each a very limited jurisdiction. That of the prefectorial councils, on the other hand, is very considerable, although as a matter of fact these councils are occupied almost altogether with questions of taxes, and in these, as a rule, they follow the advice

incidentally award compensation. Finally actes de goucrnement, that is acts done for reasons of state with a view to the public safety, whether within the legal power of the government or not, lie beyond the jurisdiction both of the ordinary and the administrative courts; but there is a distinct tendency to restrict this principle to an ever narrowing field.

It is obvious that while the French system does not hold the official to a rigid conformity with law, it often gives compensation from the public treasury for tortious acts of officials when in England or America there would be no redress, or only an action against an official who might be unable to pay the damages.

It is somewhat curious in this connection to observe that French writers often assert the inability of an ordinary court to protect the public against illegal ordinances, because it can only decide the case at bar, whereas an administrative court has power to annul the ordinance altogether; a remark which shows an entire failure to comprehend the force of precedent in the Anglo-Saxon judicial system. (See, for example, Varagnac, "Le Conseil d'Etat," Revue des Dcux Mondes, Sept. 15, I892, pp. 290-29r.)

A systematic comparison of the English and French systems may be found in Professor Dicey's Law of the Constitution, and especially in chapter xii.

1 On this subject, see Laferrière's great work, Trailé de la Jurisdiction Administrative. 
of the assessors. ${ }^{1}$ But by far the most important administrative court is the Council of State, which has a special section or committee to attend to the contcnticux, as this class of litigation is called. The Council not only hears appeals from the lower administrative tribunals, but has also original jurisdiction in many important cases; and, in fact, recent practice is tending to establish the principle that the Council of State is the judge of all administrative matters in the absence of special provisions of law. The number of cases brought before it is very large, and has increased so rapidly that the section for the contentieux is badly in arrears, and it has been proposed to create a second section to relieve the pressure. ${ }^{2}$

\section{The Court of Conflicts}

It is evident that with two sets of courts, neither of which is superior to the other, disputes about jurisdiction must constantly arise. Such is in fact the case, and a special tribunal has been appointed to determine these disputes, or conflicts as they are called. ${ }^{3}$ It is composed of the Minister of Justice, of three members of the highest court of law, the Court of Cassation, of three members of the highest administrative court, the Council of State (each of these sets being selected by their own court), and of two other persons elected by the foregoing seven. All the members are chosen for three years, except the Minister of Justice. This officer has the right to preside, and thus his presence gives to the administration a majority in the tribunal. A striking example of the working of the system was presented

1 Vicomte d'Avenel, "La Réforme Administrative - La Justice," Revue des Deux Mondes, June I, r889, p. 596.

2 For the number of cases decided by the administrative courts, see the tables (through 1886 ) in Laferrière, liv, $i$, ch. $v$.

${ }^{3}$ Aucoc, Conf., vol. i, § 406; Bœuf, Résumé, I5th ed., pp. 542-543. 
in 1880 , when the government issued decrees for the suppression of all monastic orders not authorized by law. There seems to have been grave doubt about the legality of the decrees, and the victims brought suits in the ordinary courts in several parts of France. Most of these courts held that they were authorized to entertain the suits, and in some cases they went so far as to order the persons who had been expelled from their establishments to be restored to possession pending the trial; ${ }^{1}$ but the government raised the question of jurisdiction, and the Tribunal of Conflicts decided that the ordinary courts were not competent to deal with the matter. ${ }^{2}$ It is a significant fact, which seems to show a lack of confidence in the impartiality of the administrative courts, that the persons injured did not bring the question of the legality of the decrees before the Council of State. ${ }^{3}$

When an ordinary court has assumed jurisdiction of a case, the question of competence can be raised only by the prefect, and not by a party, for the principle that the ordinary courts cannot determine the legality of official acts is intended solely as a protection to the administration. ${ }^{4}$

\section{The State of Siege}

Such is the legal position of the administration in ordinary times, but in case of war or insurrection it can be given far

${ }^{1}$ Some of the decisions to this effect may be found in Dalloz, Jurisprudence Générale, 1880 , part iii, pp. 57-62, and 80 . In the note to page 57 there is a list of some of the other similar decisions and a discussion of the law.

${ }^{2}$ Arrêts de Nov. 4, 5, I3, I7, and 20; Dalloz, I880, part iii, pp. I21-132. These cases are reported with unusual fullness.

${ }^{3}$ At least I can find no decision on the subject by the Council of State reported in Dalloz. For criticisms on the conduct of the government, see Jules Simon, Dieu, Partie, Liberlé, ch. vi; and Channes, Nos Fautes, letters of July 12 and Oct. 27 , I880.

${ }^{4}$ Aucoc, Conf., vol. i, § 404; Bœuf, Résumé, r5th ed., p. 547. 
greater powers, by a proclamation of the state of siege. This can be made by statute, or if Parliament is not in session it can be made by the President; but in that case in order to meet the danger of a coup d'état, which is ever present to the eyes of Frenchmen, it is provided that the chambers shall meet as of right in two days. ${ }^{1}$ Within the district covered by the state of siege, the military courts can be given criminal jurisdiction, and can punish any offenses against the safety of the Republic or the general peace. They can search houses by day or night, expel from the district any non-residents, scize all arms, and forbid any publications or meetings which are liable to disturb the public order. ${ }^{2}$

\section{Effect on the Executive}

I have dwelt at some length on what, from an AngloSaxon point of view, may well be called the legislative and judicial powers of the executive in France, because these things are entirely foreign to our own political ideas and experience, and because they exist in some form in almost every country on the continent of Europe.

When we consider the paternal character of the government, the centralization of the state, and the large share of authority vested in the executive department, we cannot fail to see that the ministers in whose hands this vast power is lodged must be either very strong or very weak. If they are able to wield it as they please, and are really free to carry out their own policy, they must be far stronger than any officer or body in Great Britain, and immeasurably stronger than any in our federal republic. But, on the other hand, the very immensity and pervasiveness of their power, the fact that it touches closely every interest in the country,

1 Law of April 3, 1878, Poudra et Pierre, $\$ 79$.

2 Poudra et Pierre, $\S 76$, gives the text of the law. 
renders them liable to pressure from all sides. It becomes important for every one to influence their action, provided he can get a standpoint from which to bring a pressure to bear. This standpoint is furnished by the Chamber of Deputies, for the existence of the ministry depends on the votes of that body. The greater, therefore, the power of the minister, and the more numerous the favors he is able to bestow, the fiercer will be the struggle for them, and the less will he be free to pursue his own policy, untrammeled by deputies, whose votes he must win if he would remain in office. A Frenchman, who is eminent as a student of political philosophy, and has at the same time great practical experience in politics, once remarked to the author, "We have the organization of an empire with the forms of a republic." 1 The French administrative system is, indeed, designed for an empire, but when arbitrary power falls under the control of popular leaders, it is liable to be used for personal and party ends; for, as a keen observer has truly said, the defect of democracy lies in the fact that it is nobody's business to look after the interests of the public.

1 Gneist expresses the same idea: "Es entsteht der unvermittelte Gegensatz einer republikanisch gedachten Verfassung mit einer absolutistisch organisirten Verwaltung." (Die Preussiche Kreisordnung, p. 7.) 


\section{CHAPTER VII}

\section{FRANCE: PARTIES}

\section{Parties in Popular Government}

For more than a hundred years it has been the habit to talk of government by the people, and the expression is, perhaps, more freely used to-day than ever before, yet a superficial glance at the history of democracy ought to be enough to convince us that in a great nation the people as a whole do not and cannot really govern. The fact is that we are ruled by parties, whose action is more or less modified, but never completely directed, by public opinion. Rousseau, indeed, shadowed forth a great truth, when he declared that no community could be capable of a general will - or, as we should express it, of a true public opinion - where parties or sects prevailed ${ }^{1}$ and our own experience of popular government will quite justify us in saying that public opinion is always more or less warped by the existence of party ties. A study of the nature and development of parties is, therefore, one of the most important that can occupy the student of political philosophy to-day. Among Anglo-Saxon peoples, who have had a far longer experience in self-government than most other races, there are usually two great parties which dispute for mastery in the state. But in the countries on the continent of Europe this is not usually true. We there find a number of parties or groups which are independent of each other to a greater or less extent, and form coalitions, sometimes of a most unnatural kind, to support or oppose the government of the hour. Now the existence of

\& Contrat Social, liv. ii, ch. iii. 
several distinct political groups has a decisive influence on the working of the parliamentary system. Let us consider this question a moment.

\section{The Parliamentary System and Parties}

In describing the English government the relation of political parties to the parliamentary system was discussed, but it may not be out of place here to recall what was there pointed out.

When a country with a parliamentary form of government is divided into two hostile parties, the ministers who lead the majority of the popular chamber must of course belong all to one of those parties, or all to the other, and even when party strife is less bitter, and parties have begun to break up, experience has proved that the best policy for the ministers is to support each other and stand or fall together. Lord Melbourne is reported to have exclaimed at a cabinet meeting, after a discussion on the question of changing the duty on corn, "Now is it to lower the price of corn, or is n't it? It is not much matter which we say, but mind, we must all say the same." " The statesmanship implied by this remark may not have been of the highest kind, but the politics were sound, and showed a knowledge of the great secret of success. It is, indeed, an axiom in politics that, except under very peculiar circumstances, ${ }^{2}$ coalition ministries are short-lived compared with homogeneous ones, whose members are in cordial sympathy with each other. Now so long as the ministers cling together, every member of the House must consider the cabinet and its policy as a whole, and make up his mind whether he will support it, or help to turn it out and put in an entirely different set of

1 Bagehot, English Constilution, p. I6, note.

2 Like those brought about by this war. 
ministers with another policy. He cannot support the cabinet on certain questions and oppose it on others. He must sacrifice details to the general question. The result is that the members either group themselves about the ministers, and vote with them through thick and thin, or else they attach themselves to an opposition party, whose object is to turn out the cabinet, and then take office itself and carry on a different policy. The normal condition of the parliamentary system, therefore, among a people sufficiently free from prejudices to group themselves naturally, and possessing enough experience to know that the practical and attainable, and not the ideal, is the true aim in politics, is a division into two parties, each of which is ready to take office whenever the other loses its majority. This has been true in England in ordinary times, and although of late years it has been frequently asserted that the two great parties in the House of Commons are destined to come to an end, and be replaced by a number of independent groups, the prophecy does not accord with experience. It is based on mistaking a temporary political condition for a permanent one. The sudden interjection of the question of Home Rule into English politics caused a new party division on fresh lines, which necessarily broke up the traditional associations of public life, and threw both parties into a state of confusion for a great many years. On one side, the opponents of the measure were composed of men whose habits of thought had been most diverse; while the followers of Mr. Gladstone, on the other side, included many Liberals who were forced, against their will, to subordinate to Home Rule other matters which they deemed more important. In short, the introduction of a new issue shattered the old basis of cleavage, and it is not surprising that new, solidified parties were not formed in an instant. Moreover it may be noticed that 
although the Liberal groups in the House of Commons have often talked freely of their dissensions, they have acted as a single party, and have supported the cabinet by their votes, with astonishing fidelity.

A division into two parties is not only the normal result of the parliamentary system, but also an essential condition of its success. Suppose, for example, that a third party, like that of the Irish Home Rulers under Parnell, is formed, and places some one specific issue above all others, with the determination of voting against any cabinet which does not yield to its demands on that point; and suppose this body becomes large enough to hold the balance of power. If, in such a case, the two old parties do not make a coalition, or one of them does not absorb the new group by making concessions, no ministry will be able to secure a majority. Every cabinet will be overthrown as soon as it is formed, and parliamentary government will be an impossibility. Now suppose that the third party, instead of being implacably hostile to both the others, is willing for a time to tolerate a cabinet from one of them - is willing, in short, to allow the ministers to retain office provided they give no offense. Under these circumstances parliamentary government is not impossible, but it is extremely difficult. The ministers are compelled to ride two horses at once. They must try to conciliate two inharmonious bodies of men, on pain of defeat if either of them becomes hostile; and hence their tenure is unstable and their course necessarily timid. Now the larger the number of discordant groups that form the majority, the harder the task of pleasing them all, and the more feeble and unstable the position of the cabinet. Nor is the difficulty removed by giving portfolios to the members of the several groups; for even if this reduces the labor of satisfying the parties, it adds that of maintaining an accord among the 
ministers themselves, and entails the proverbial weakness of coalition governments. A cabinet which depends for its existence on the votes of the Chamber can pursue a consistent policy with firmness and effect only when it can rely for support on a compact and faithful majority; and therefore the parliamentary system will give the country a strong and efficient government only in case the majority consists of a single party. But this is not all. The opposition must also be united. So long as the ministry stands, the composition of the minority is, indeed, of little consequence; but when that minority becomes a majority, it must in turn be a single party, or the weakness of a coalition ministry cannot be avoided. It follows that a division of the Chamber into two parties, and two parties only, is necessary in order that the parliamentary form of government should permanently produce good results.

\section{Many Groups in France}

In France the parliamentary system has not worked smoothly, because this condition has not been fulfilled. ${ }^{1}$ The various groups of Monarchists and Bonapartists formed in the traditional party of the Reactionaries, or as it was more commonly called, the Right. ${ }^{2}$ The rest of the members have

1 This is recognized by many French writers, e.g., Lamy, La République en $188_{3}$; Paul Laffitte, Le Suffrage Universel et la Régime Parlementaire, pt. i, ch. iii; Saleilles, in the Annals of the American Academy of Political Science, July, $1895, p p .57,64,65$. But the reason for the existence of a number of groups in France seems to be only partially understood. The most clearsighted writer on this subject is Dupriez. (See Les Ministres, ii. 363-365, $370-371$, and $386-395$.)

${ }^{2}$ For readers unfamiliar with European politics it may perhaps be necessary to explain the meaning of the terms Right and left, as they are used all over the Continent. In England a broal aisle runs from the Speaker's desk through the middle of the House of Commons to the main entrance opposite, and the benches of the members are arranged parallel to this aisle and facing it. The Ministry sit on the front bench at the right of the Speaker 
been supporters of the Republic, and have formed nominally a single party, but they have really been held together only by a desire to maintain the existing form of government, and have seldom acted in concert except when they thought that threatened. They have always comprised men of every shade of opinion, from conservatives to radicals and even socialists, and would speedily have broken up into completely hostile parties, if it had not been for the fear of the Reactionaries. Even under the pressure of this fear their cohesion has been very slight, for they have been divided into a number of groups with organizations which, though never either complete or durable, have been quite separate; and again, these groups have often been subdivided into still smaller groups, whose members were loosely held together by similarity of opinions or desire for advancement, usually under the standard of some chief, who held, or hoped to win, a place in the cabinet. In fact, the parties in the Chamber of Deputies have presented such a series of dissolving views that it is very difficult to draw an intelligible picture of them. ${ }^{1}$

(the so-called Treasury Bench), their supporters taking seats behind and alongside of them, while the Opposition sit on the left side of the House. The Liberals and Conservatives, therefore, are each to be found sometimes on one side of the House and sometimes on the other, according as their party is in power or not. But on the Continent the seats are arranged, as a rule, like those of a theatre, as in our legisaltive bodies, the ministers usually sitting immediately in front of the Speaker or President, on a bench which sometimes faces him and sometimes looks the other way, while the conservative members sit on the President's right, the more liberal next to these, and the radical on his left. As this arrangement is permanent, the words Right and Left have come to be generally used for Conservative and Liberal; and the different groups are often designated by their position in the Chamber, as the Right, the Centre, and the Left Centre, the Left, or the Extreme Left.

1 'The line of cleavage between the monarchists and republicans has now ceased to be of much importance. All the larger factions now profess to be republican. These factions are constantly gaining or losing members so that it is almost impossible to state their exact numerical strength at any 
During the struggle with MacMahon, the Republicans had been solidly united, but the danger had not passed very long before the Radicals began to show themselves independent. They soon became quite ready to upset any ministry that offended them, and in fact cabinet after cabinet was overthrown by the votes of the Right and the Extreme Left. Even Gambetta, who had striven to keep the Republicans together, did not escape this fate, in spite of his immense popularity both in the country and in the Parliament. He did not consent to form a ministry until November, I88I ; and after holding office only two months and a half, he was forced to resign by the refusal of the Chamber to introduce the scrutin de liste for the election of deputies. He lived only till the end of the year, and his death deprived France of a great popular leader. After his fall, politics followed the old course, and there passed across the stage a series of shortlived ministries.

During the last few years there has indeed been a nearer approach to a division of the deputies into two great parties - one Conservative and the other Radical - than at any other time since the birth of the Republic; and yet the history of the successive ministries during the life of the later chambers makes it clear with how little sharpness the lines are drawn, and how little the members of the various groups

one time. Sometimes it happens, indeed, that a member of the Chamber may profess to belong to two political groups at the same time. No single faction ever forms a majority of the Chamber so that a coalition is always necessary. The following groups at present make up the Chamber of Deputies but their names afford, for the most part, no indication of the principles to which they give allegiance: Conservatives (or members of the extreme Right); Nationalists (members of the Action Libérale populaire); Progressives; Republicans (or Moderates); Radicals; Radical-Socialists; Independent Socialists; and Independents. The first three groups make up the Right; the last five usually make up the Left; but some of the smaller groups keep shifting from side to side. 
that compose the majority can be relied upon to be faithful to the cabinet. In short, there has been an approach to the system of two parties, but as yet not a very near approach, and the numerous detached groups still remain the basis of parliamentary life.

Let us now consider the reasons for the subdivisions of the Chamber into a number of groups. And first we must look at a source of political dissensions with which we are not familiar at home, but which is to be found in almost every nation in Europe.

\section{The Lack of Political Consensus}

Few persons ever ask themselves why the bodies of men who assemble every year at the State House or the Capitol have power to make laws. It is not because they have more personal force or wisdom or virtue than any one else. A congress of scientific men may contain all these qualities in greater abundance, but it cannot change a single line in the statute-book. Is it because they represent the people? But we all know that they occasionally pass laws which the people do not want, and yet we obey those laws without hesitation. Moreover, this answer only pushes the question one step further back, for why should we obey the people? A few centuries ago nobody recognized any right on the part of the people to govern or misgovern themselves as they chose, or rather on the part of the majority to impose their will on the minority; and in many countries of the world no such right is recognized to-day. How does it happen that there is not a class of men among us who think that the legislature does not fairly represent the people, or who think that the right to vote ought to be limited by a certain educational or property qualification, or by the profession of a certain creed; and why does not some such class of men get 
up a rival legislature? The fact is that, while we may differ in regard to the ideal form of government, we are all of one mind on the question of what government is entitled to our actual allegiance, and we are all determined to yield to that government our obedience and support. In short, a common understanding or consensus in regard to the basis and form of the government is so universal here that we feel as if it were natural and inevitable; but in all countries this is not so. Such a consensus is the foundation of all political authority, of all law and order; and it is easy to see that if it were seriously questioned, the position of the government would be shaken, that if it were destroyed, the country would be plunged into a state of anarchy.' Now persons who do not accept the consensus on which the political authority of the day is based are termed in France Irreconcilables. Men of this sort do not admit the rightfulness of the existing government; and, although they may submit to it for the moment, their object is to effect a revolution by peaceful if not by violent means. Hence their position is essentially different from that of all other parties, for these aim only at directing the policy of the government within constitutional limits, and can be entrusted with power without danger to the fundamental institutions of the nation, while the Irreconcilables, on the contrary, would use their power to upset those institutions, and therefore cannot be suffered to get control of the state. They form an opposition that is incapable of taking office, and so present a disturbing element, which in a parliamentary form of government throws the whole system out of gear. ${ }^{2}$

1 The revolution in Russia and its sequal is a forcible illustration of this truth.

${ }^{2}$ It is impossible to draw a sharp line between what is revolutionary and what is not; or to define exactly an Irreconcilable. The matter depends in fact upon the opinion of the community. Thus, before r856, Home Rule 
Another thing to be noticed about a consensus is that it cannot be created artificially, but must be the result of a slow growth and long traditions. Its essence lies in the fact that it is unconscious. The people of the United States, for example, could not, by agreement, give to a dictator the power of the Czar of Russia, for except in the presence of imminent danger he would have no authority unless the people believed in his inherent right to rule, and the people cannot make themselves believe in any such right simply by agreeing to do so. The foundation of government is faith, not reason, and the faith of a people is not vital unless they have been born with it. ${ }^{1}$ Now, in France, the Revolution of I 789 destroyed all faith in the political institutions of the past, and was unable to substitute anything else. It did, indeed, give birth to a code of law, and to an administrative system, both of which have taken a strong hold on the nation, and have survived every change in the government. These have been the permanent elements in France, and the only ones that acquired the blind force of tradition. They have supplied a machinery unshaken by political upheavals, and it is this that has made it possible for the country to pass through so many revolutions without falling into a state of anarchy. ${ }^{2}$ But in regard to institutions of a purely politimight fairly be said to have been revolutionary, and the Irish Home Rulers to have been Irreconcilables; but after Mr. Gladstone made Home Rule a practical question in English politics, it would have been absurd to call Parnell's followers Irreconcilables.

${ }_{1}$ Curiously enough an exception to this principle, and almost a solitary one, is to be found in the history of the United States. The generation that framed the Constitution looked upon that document as very imperfect, but they clung to it tenaciously as the only defense against national dismemberment, and in order to make it popular, they praised it beyond their own belief in its merits. This effort to force themselves to admire the Constitution was marvelously successful, and resulted, in the next generation, in a worship of the Constitution, of which its framers never dreamed.

${ }^{2}$ Cf. Laffitte, pp. 208, 209. 
cal character, the nation has not been so fortunate, for the governments that followed the Revolution were not sufficiently durable to lay even a foundation for a general consensus, and the lack of continuity so thoroughly prevented the steady growth of opinion that only of late years have the people as a whole succeeded in acquiring a political creed. The result is that every form of government that has existed in France has had its partisans, who were irreconcilable under every other; while the great mass of the middle classes and the peasants had no strong political convictions, and were ready to support any government that maintained order. Thus the two Empires bequeathed to the Republic the group of Bonapartists, whereas the Monarchists were a legacy from the old régime and the reign of Louis Philippe. At present, the Right having accepted the Republic, and the irreconcilable elements disappearing or becoming insignificant, one of the chief obstacles to the formation of two great parties, one Conservative and the other Radical, has been removed. ${ }^{1}$

But this is only one of several obstacles, and the others are so great that it will probably be a long time before the system of groups breaks down in France, or is replaced by that of two political parties.

\section{French Political Opinions Theoretical}

In the first place, the Frenchman has been theoretical rather than practical in politics. He has tended to pursue an ideal, striving to realize his conception of a perfect form of society, and is reluctant to give up any part of it for the sake of attaining so much as lies within his reach. Such a tendency naturally gives rise to a number of groups, each with a

1 During the present war, there has certainly been no strong recrudescence of irreconcilable opinion. 
separate ideal, and each unwilling to make the sacrifice that is necessary for a fusion into a great party. In short, the intensity of political sentiment tends to prevent the development of real political issues. To many Frenchmen, public questions have an absolute rather than a relative or practical bearing, and therefore they care more for principles and opinions than for facts. This tendency is shown in the programmes of the candidates, which are apt to be philosophic documents instead of statements of concrete policy, and, although published at great length, often give a comparatively small idea of the position of the author on the immediate questions of the day. ${ }^{1}$ It is shown also in the newspapers, and the use that is made of them. An AngloSaxon reads the newspapers chiefly for information about current events, and as all the papers contain very much the same news, he habitually reads only one. But the French papers contain far less news, and as the Frenchman reads them largely for the sake of the editorials, he commonly reads several in order to compare the opinions they express.

It is partly on account of this mental attitude, and partly owing to the absence of the habit of self-government, and the lack of sympathy between different parts of the country,

\section{Lebon, France as It Is, p. 85.}

Abstracts of all the electoral programmes issued by the successful candidates for the Chamber of Deputies at the elections of 1889 and 1893 , together with the results of the ballots, have been published by Duguet, under the titles Les Députés et les Cahiers Electoraux. These volumes are very instructive; and a perusal of them shows that the programmes of the Radicals are much longer and less vague than the others, but often demand measures which lie out of the domain of practical politics, such as revision of the Constitution, abolition of the Senate, elective judiciary, etc. The programmes gave a very good idea of the candidate's general turn of mind; and those of the Radicals may be said to contain their conception of the ideal state of politics or of society. The Radicals are, indeed, the only group among the Republicans that can be said to have anything like a positive programme, and this is the source both of their strength and their weakness. 
that the French have not organized readily in politics. This is the more curious because in military matters they organize more easily than any other people in the world; and it is no doubt the military instinct, as well as the want of confidence in their own power of political organization, that disposes them to seek a leader and follow him blindly after he has won their confidence. ${ }^{1}$ The inability to organize readily in politics has this striking result, that vehement as some of the groups are, and passionate as is their attachment to their creeds, they have made little effort to realize their aims by associating together their supporters in all parts of the country for concerted action. In fact, there may be said to be no national party organizations in France. ${ }^{2}$ The various groups into which the deputies are divided have, as a rule, no existence whatever outside of Parliament, the candidates for seats merely calling themselves, in general terms, Moderates, Radicals, Socialists or simply Republicans without further qualification, and attaching themselves to a particular group after the Chamber has met. Moreover, the programmes, which are drawn up by each candidate for himself, are only individual confessions of faith, and are all different, so that there is no policy which any party as a whole is pledged to support. Before the opening of the campaign, indeed, party gatherings or banquets take place, and speeches are made, but until recent elections, no common platform of principles has been issued except by the Socialists. $^{3}$ It is after the campaign has begun, however, that the absence of party organization is most clearly seen. Then the

1 Cf. Channes, Letter of Aug. 22, 1885.

${ }^{2}$ Cf. Lebon, France as It Is, p. 75; Theodore Stanton in the North American Rev., clv. 47I. This contrasts strangely with the United States, where the machinery of a party has sometimes shown more vitality than its principles.

${ }^{3}$ Daniel, L'Année Politique, I893, pp. 254-280. 
struggle is conducted in each electoral district with very little regard to the rest of the country, and in fact each district appears like a separate nation engaged in a distinct contest of its own. ${ }^{1}$ Political effort becomes localized, and except for the candidates themselves, who confine their labors to their constituencies, it has often happened that scarcely a man of prominence opened his mouth.

\section{Effects of French Political Mechanism}

One might suppose that under a parliamentary form of government party organization would hardly be required, and that, as in England, the need of political cohesion would be to a great extent supplied by a strong ministry that really led Parliament and the nation. But here we meet with some of the other causes that tend to produce a multiplicity of groups - causes that spring from certain of the minor French institutions which were referred to in the beginning of the first chapter as inconsistent with the parliamentary system. Three of these are especially important - the method of electing deputies, the system of committees in the chambers, and the practice of interpellations.

\section{The Method of Electing Deputies}

In France the scrutin de liste, or the election of all the deputies from a department on one ticket, and the scrutin d'arrondissement, or the use of single electoral districts, have prevailed alternately, the latter being in force at the present day. ${ }^{2}$ But under both systems an absolute majority of all the votes cast is required for election. If there are more than two candidates in the field, and no one of them gets such a majority, a second vote, called the ballotage, is taken two

1 Comte de Chaudordy, La France en 1889 , p. 89.

2 See, however, note on p. 17, ante. 
weeks later, and at this a plurality is enough to elect. ${ }^{1}$ Now it is clear that such a procedure encourages each political group to nominate a separate candidate for the first ballot. Suppose, for example, that there are Reactionary and Moderate Republican candidates in the field, and that the Radicals prefer the Republican to the Reactionary, still they have nothing to lose by running a candidate of their own on the first ballot, for if the Reactionary can poll more votes than both his rivals combined, he will be elected in any event; if he cannot, he will not be elected whether the Radicals put up a candidate of their own or not. In this last case, the first ballot will have counted for nothing, and the Radicals will be able to vote for the Moderate Republican at the ballotage, and elect him then. They are likely, indeed, to gain a positive advantage by nominating a separate candidate, for if they succeed in polling a large vote on the first ballot, they are in an excellent position to wring concessions from the Moderates as a price of their support.

Cumbrous as it is, this system of voting dates back to the election of the States General in 1789 , and, with a couple of short breaks, has been maintained in France ever since. ${ }^{2}$ The idea that a representative ought to be the choice of a

1 Law of June I6, I885, Art 5. (This article was not repealed by the Law of Feb. I3, I889.) By the same article a quarter as many votes as there are voters registered is required for election on the first ballot.

According to strict parliamentary usage, the term ballotage is applied only to cases where, at the final trial, the voting is confined by law to the two names highest on the poll at the preceding ballot, but the word is popularly used for any final ballot where a plurality is decisive.

For the choice of a senator by the electoral college of a department, the votes of a quarter of the college, and a majority of all the votes actually cast, are required on the first two ballots, while on the third a plurality is enough. Law of August 2, I875, Art. 15. The election of delegates to the college by the municipal councils is conducted in the same manner. Law of Dec. 9, I884, Art. 8.

2 Poudra et Pierre, liv. ii, ch. vii. 
majority of the people seems, indeed, to be natural in democracies, for we find it put in practice elsewhere. 'Thus, in the United States, a majority vote was formerly very commonly required for election, but it is instructive to notice that it was found to hinder the smooth working of two political parties, and has been generally though not quite universally abandoned.' The fact that election by majority did not give rise to a multiplicity of parties in America shows that by itself it does not produce that result, where the other influences favor the development of two parties; but it is nevertheless clear that where a number of groups exist, it tends to foster them, and prevent their fusing into larger bodies. ${ }^{2}$ The French system has been praised on the ground that it saves the people from the yoke of huge party machines, and enables them to select their candidates more freely. ${ }^{3}$ This is true, and it is a great advantage. But the converse is also true; the system tends to prevent the formation of great consolidated parties, and that is the evil from which parliamentary government suffers in France to-day. ${ }^{4}$

1 Stimson, Am. Statute Law, $\S 232$. In Massachusetts, election by plurality was introduced in 1855 . Const. of Mass., Amendments, Art. xiv. For the previous law, see Const., pt. ii, ch. i, sec. ii, Art. iv; ch. ii, sec. xiii, Art. iii; sec. ii, Art. i; Rev. Stats., ch. iv, sec. xiii.

2 At the elections of 1885 , which were held under the system of scrutin de liste, there were two Republican lists of candidates in almost all the departments. G. Channes, Letter of Oct. 30, 1885. At the elections of 1889 and 1893 , held under the scrutin d'arrondissement, there were two Republican candidates in a large proportion of the districts, the total number of candidates for a single seat running as high as ten. Duguet, Les Députés et les Cahiers Electoraux en I889; Id., I 893. And see Tableau des Elections à la Chambre des Députês, dressé aux Archives de la. Chambre.

3 Alfred Naquet, "The French Electoral System," in the North Am. Rev., clv. 467-468.

4 It is not a little curious that just at the time, when the English system of two parties was thought by many people to be in danger of breaking up, a motion should be made in the House of Commons to introduce election by majority vote and second ballot. Such a motion was made by Mr. Daziel on April 5, I895. 


\section{The Committees in the Chambers}

The system of committees in the chambers is a still more important matter. Each of the French chambers is divided into sections called bureaux, of which there are nine in the Senate and eleven in the Chamber of Deputies. 'The bureaux are of equal size, and every member of the Chamber belongs to one and only one of them, the division being made afresh every month by lot. This is a very old institution in France, a relic of a time before parliamentary government had been thought of; for not only do we find it in the Assembly of Notables and the States General that met on the eve of the Revolution, ${ }^{2}$ but it existed in the ecclesiastical assemblies, and to some extent in the States General, at a much earlier date. ${ }^{3}$ The use of the lot is, indeed, a survival from the Middle Ages, when it was a common method of selecting officials. ${ }^{4}$ The bureaux meet separately and have three functions. The first is that of making a preliminary

1 For the constitution of the bureaux and the election of the committees, see Poudra et Pierre, liv. v, chs. ii and iii; Pierre, Traité de Droit Politique, Electoral et Parliamentaire, $4^{\text {th }}$ ed. with supp., book vi, § 2. Reginald Dickinson, Summary of the Constitution and Procedure of Forcign Parliaments, 2d ed., pp. 393-366.

These bureaux must not be confounded with the Bureau of the Chamber, which consists of the President, the Vice-Presidents, and the Secretaries. The habit in France of using the same word with different meanings is liable to be the source of no little confusion to the students of her institutions.

${ }^{2}$ Poudra et Pierre, $\S 976$.

${ }^{3}$ Sciout, Histoire de la Constitution Civile du Clergé, p. 36. Judge Francis C. Lowell pointed out to me that the States General which met at Tours in 1484 was divided into six sections by provinces. See a journal of this body by Jehan Masselin, in the Collection de Documents inédits sur l'Histoire de France publiés par ordre du Roi, Paris, 1835, pp. 66-73.

4 The chief relic of the lot left in Anglo-Saxon institutions is, of course, its use in the selection of the jury - a surviral which is due to the fact already pointed out, that the English royal justice developed at an early period. 
examination of the credentials of members of the Chamber, which are divided among them for the purpose. The second is that of holding a preliminary discussion on bills brought into the Chamber, before they are referred to a committee; but as a matter of fact this discussion is perfunctory, and is limited to finding out in a general way what members of the bureau favor or oppose the bill. ${ }^{1}$ The third and most important function of the bureaux is the election of committees, for with some exceptions all the committees of both chambers are selected in the same way. Each of the bureaux chooses one of its own members, and the persons so elected together constitute the committee. In the case of the more important committees it is sometimes desirable to have a larger number of members, and if so the bureaux choose in like manner two or even three members apiece - the chamber in each case directing, by its rules or by special vote, the number of members to be elected. Thus the committee on the budget, which is the most important one of the year, consists of three members chosen by each of the bureaux in the Chamber of Deputies, and contains, therefore, thirty-three members; while the corresponding committee in the Senate contains eighteen members, or two from each bureau.

The committee on the budget and the one appointed to audit the accounts of the government have long been permanent, remaining unchanged for a year. With these exceptions every measure is in theory referred to a special committee elected by the bureaux for the purpose; but as there are certain to be in every session a number of bills that cover very much the same ground, a rigid application of this principle would result in inconsistent reports on the same matter by different committees, and would throw the work 
of the Chamber into utter confusion. There have, therefore been a number of committees that are treated in the Chamber as virtually permanent, and of late years these have tended to increase until there are a dozen and a half of them. There has also been a tendency for the Chamber itself to elect committees by scrulin de liste instead of by the bureaux.

Now the bureaux, being created anew every month, acquire no corporate feeling, and hence have no real leaders. Owing partly to this fact they do not choose freely, and the chief of the parliamentary groups meet and barter away the places on the important committees, which are thus cut and dried beforehand. ${ }^{1}$ But whether the choice of committeemen is really made by the bureaux or dictated by the chiefs of the groups, the main point to notice is that the system is inconsistent with the parliamentary form of government. The cabinet cannot exert the same influence over an election conducted in this way that it could over one made by the Chamber in open session. In the latter case it might insist on the choice of a majority of the committee from among its own friends, and make of the matter a cabinet question; but it cannot treat the failure of several irresponsible sections of the Chamber to act in accordance with its wishes as an expression of want of confidence by the Chamber as a whole. The result is that the committees are not ordinarily nominated by the cabinet, or necessarily in sympathy with it; and yet all measures, including those proposed by the government, are referred to them to revise as they think best. But if the ministers are to be responsible for directing the work of the Chamber, they ought to have a policy of their own and stand or fall on that. They ought to be at liberty to determine their own course of action, and to pre-

1 Cf. Simon, Nos Hommes d'Etat, pp. 41, 24I. 
sent their measures to Parliament in a form that they entirely approve.

If a committee has power to amend government bills, the ministers must either assume the burden of trying to persuade the Chamber to reverse the amendments. with all the infuence of the committe egainst them: or they must take the risk of opposing the bill as zeported. although they still approve of many ofic ieatures: or inally they must accept the bill as it stands. and become responsible for a measure with which they are not themselves fully sutisied. The committees in iact use their power without shrinking: and the annual budget, for example, has been compared to a tennis-ball sent backward and iorward between the minister and the committee urtil a compromise can be reached.

M. Duprez. in his excellent wort on the ministers in the principal countries of Europe and America. paints in very strong colors the evils of the French committee system. He points out how little infuence the ministers have with the committees. who oiten regard them almost as the representatives of a hostile power in the state." He shows that while the ministers have no right to be present at committee meetings. and are invited to attend only when they wish to express their views. the committees claim a right to examine the administrative offces. insist on seeing books and papers, and volurteer advice. ${ }^{3}$ So little respect, indeed. do the committes pay to the opinions oi the cabinet. and so freely do they amend its bills, that, as M. Dupriez sarcastically remarts, the government and the committee are never in perfect accord except when the former submits to the latter." He says. moreover. that when a bill comes up for debate the

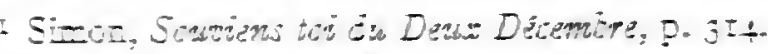

: Vol ii $206-\div 0 \%$

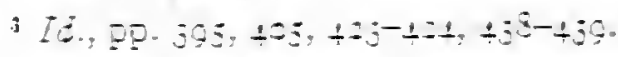

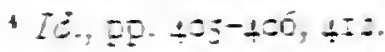


reporter of the committee is a rival who has great influence with the Chamber, while the deputies are inclined to regard the ministers with jealousy and defiance. ${ }^{1}$ Nor do the woes of the cabinet end here, for its bills are quite freely amended during the debate on the motion of individual deputies. ${ }^{2}$

Of all the committees, the most domineering and vexatious is that on the budget. This committee seems to take pride in criticizing the estimates and making them over, both as regards income and expenditures, while each member exerts himself to add appropriations for the benefit of his own constituents, so that when the report is finally made the government cannot always recognize its own work. ${ }^{3}$ In strong contrast with all this is Dupriez's description of the procedure on the budget in England. ${ }^{4}$ There the authority of the ministers is expressly protected by the standing order of the House of Commons to the effect that no petition or motion for the expenditure of the public revenue shall be entertained except on the recommendation of the crown; and in accordance with a firmly established practice proposals for national taxes originate only with the government. The comparison of the English and French methods of dealing with the budget goes far to explain the difference in the position of the two cabinets. Such a state of things as exists in France cannot fail to lessen the authority and dignity of the ministers, and place them at the mercy of the committees. It prevents them from framing their own programme, and insisting that the deputies shall accept or reject it as it stands; and thus, instead of compelling the majority to act solidly together under the leadership of the cabinet, it allows any deputy to use his place on a committee as a means of urging his own personal views. Hence it tends
I Dupriez, ii. 4 Ir.
${ }^{3} I d .$, pp. 425-426.
2 Id., p. 4I 2.
${ }^{4} I d .$, i. IrO-II 2. 
to dislocate the majority and break it into sections, with policies more or less out of harmony with each other. While, therefore, the French scheme of committees has good points, and some features that might be very valuable under another form of government, it is clearly incompatible with the parliamentary system. ${ }^{1}$

\section{Interpellations}

The habit of addressing interpellations to the ministers has also a bearing on the stability of the cabinet and the subdivision of parties; for it cannot be repeated too often that these things are inseparable. The existence of the ministry depends on the support of the majority, and if that is compact and harmonious, the ministry will be strong and durable; if not, it will be feeble and short-lived. The converse is also true. The cohesive force that unites the majority is loyalty to the cabinet and submission to its guidance; but if the cabinets are weak, or are constantly overthrown at short intervals, they cannot acquire the authority that is necessary to lead the majority and weld it into a single party. This is especially the case when the crises occur over matters which are not of vital consequence to the bulk of the followers of the government, and yet that is precisely the state of things that interpellations tend to create.

It is of the essence of parliamentary government that the majority should support the ministers so long, and only so long, as it approves of their course, and this means their course as a whole, in administration as well as in legislation; for the parliament, having the fate of ministers in its hands,

${ }^{1}$ Lebon, L'Allemagne, p. 88, remarks that the bureaux in the French Chamber were intended to subdivide the factions, and accomplish this only too well. 
holds them responsible for all their acts, and has gradually extended its supervision over the whole field of government. Now a parliament can judge of the legislative policy of the cabinet by the bills it introduces, but it is not so easy to get the information necessary for a sound opinion on the efficiency of the administration. It is largely to satisfy this need that a practice has grown up in the House of Commons of asking the ministers questions, which may relate to any conceivable subject, and afford a means of putting the cabinet through a very searching examination. Of course the privilege is freely used to harass the government, but the answer is not followed by a general debate, or by a vote, except in the unusual case where a motion to adjourn is made for the purpose of bringing the matter under discussion. ${ }^{1}$

A similar practice has been adopted in France, and questions are addressed to the ministers by members who really want information. But another kind of question has also developed, which is used not to get information, but to call the cabinet to account, and force the Chamber to pass judgment upon its conduct. This is the interpellation. ${ }^{2}$ In form

1 The motion to adjourn is the only one that is in order, and since 1882 its use has been carefully limited. May, Parl. Practice, roth ed., p. $240 \mathrm{et} \mathrm{seq.}$ In this form or some other a vote is occasionally taken on a single detail of administration. The most famous instances of late years have been the affair of Miss Cass in 1887 , where the House of Commons expressed its disapproval of the government's refusal to make an inquiry by voting to adjourn, but where no member of the cabinet felt obliged to resign; and the defeat of Lord Rosebery's ministry in 1895 . In the last case a motion was made to reduce the salary of the Secretary of State for War, in order to draw attention to the lack of a sufficient supply of ammunition, and the motion was carried; but there can be no doubt that the cabinet would not have resigned if its position had not already been hopeless.

In the House of Lords questions can always be debated. May, p. 206.

2 For the rules and practice in the case of questions, see Poudra et Pierre, liv. vii., ch. iii., and Supp. $1879-80, \$$ 1539. In the case of interpellations, id., liv. vii., ch. iv. 
it is similar to the question, but the procedure in the two cases is quite different. A question can be addressed to a minister only with his consent, whereas the interpellation is a matter of right, which any deputy may exercise, without regard to the wishes of the cabinet. The time, moreover, when it shall be made is fixed by the Chamber itself, and except in matters relating to foreign affairs, the date cannot be set more than a month ahead. But by far the most important difference consists in the fact that the author of the question can alone reply to the minister, no further discussion being permitted, and no motion being in order; while the interpellation is followed both by a general debate and by motions. These are in the form of motions to pass to the order of the day, and may be orders of the day pure and simple, as they are called, which contain no expression of opinion, or they may be what are termed orders of the day with a motive, such as "the Chamber, approving the declarations of the Government, passes to the order of the day." Several orders of this kind are often moved, and they are put to vote in succession. The ministers select one of them (usually one proposed by their friends for the purpose), and declare that they will accept that. If it is rejected by the Chamber, or if a hostile order of the day is adopted, and the matter is thought to be of sufficient importance, the cabinet resigns. This is a very common way of upsetting a ministry, but it is one which puts the cabinet in a position of great disadvantage, for a government would be superhuman that never made mistakes, and yet here is a method by which any of its acts can be brought before the Chamber, and a vote forced on the question whether it made a mistake or not. Moreover, members of the Opposition are given a chance to employ their ingenuity in framing orders of the day so as to catch the votes of those deputies who are in sympathy with 
the cabinet, but cannot approve of the act in question. ${ }^{1}$ Now if adverse votes in the Chamber are to be followed by the resignation of the cabinet and the formation of a new one, it is evident that to secure the proper stability and permanence in the ministry, such votes ought to be taken only on measures of really great importance, or on questions that involve the whole policy and conduct of the administration. It is evident also that they ought not to be taken hastily, or under excitement, but only after the Chamber has deliberately made up its mind that it disapproves of the cabinet and that the country would on the whole be benefited by a change of ministers. The reverse of all this is true of the French system of interpellations, and a cabinet which in the morning sees no danger ahead, and enjoys the confidence of

1 A very good example of the various shades of praise or blame that may be expressed by orders of the day can be found in the Journal Officiel for July 9, 1893 . There had been a riot in Paris, which had not been suppressed without violence and even bloodshed. The police were accused of wanton brutality, and an interpellation on the subject was debated in the Chamber of Deputies on July 8. The order of the day quoted in the text, "The Chamber, approving the declarations of the government, passes to the order of the day," was adopted, but the following were also moved:

"The Chamber, disapproving the acts of brutality of which the police have been guilty, requests the government to give to the police instructions and orders more conformable to the laws of justice and humanity, and passes to the order of the day."

"The Chamber, disapproving the proceedings of the police, passes to the order of the day."

"The Chamber, approving the declarations of the government, and persuaded that it will take measures to prevent the violence of the police officials, passes to the order of the day."

"The Chamber, censuring the policy of provocation and reaction on the part of the government, passes to the order of the day."

"The Chamber, hoping that the government will give a prompt and legitimate satisfaction to public opinion, passes to the order of the day."

"Considering that the government has acknowledged from the tribune that its policy has caused in Paris 'sad occurrences,' ' deeds that must certainly be regretted,' and 'some acts of brutality,' the Chamber takes notice of the admission of the President of the Council, demands that the 
the Chamber and the nation, may be upset before nightfall by a vote provoked in a moment of excitement on a matter of secondary importance.

The frequency with which interpellations are used to upset the cabinet may be judged by the fact that out of the twenty-one ministries that resigned in consequence of a vote of the Chamber of Deputies during the years I $879-1896$, ten went to pieces on account of orders of the day moved after an interpellation, or in the course of debate, ${ }^{1}$ and since 1896 the proportion has remained substantially the same. Several of these orders covered indeed, the general policy of the cabinet, but others - like the one relating to the attendance of the employees of the state railroads at a congress of labor unions, which occasioned the resignation of Casimir-

exercise of power shall be inspired by the indefeasible sentiments of justice, of foresight, and of humanity, and passes to the order of the day."

"The Chamber, convinced that the government of the Republic ought to make the law respected and maintain order, approving the declarations of the government, passes to the order of the day."

"The Chamber, regretting the acts of violence on the part of the police, and taking notice of the declarations of the government, passes to the order of the day."

"The Chamber, approving the declaration whereby the government has announced its desire to put an end to the practices and habits of the police which have been pointed out, passes to the order of the day."

"The Chamber, convinced of the necessity of causing the laws to be respected by all citizens, passes to the order of the day."

In this case, by voting priority for the first of these motions and adopting it, the Chamber avoided the snares prepared for it by the ingenious wording of the others.

1 Cf. Haucour, Gouvernements et ministères de la II ${ }^{e}$ république française (1870-1893); Muel, Gouvernements, ministères et constitutions de la France depuis cent ans.

Among the resignations brought about in this way, I have counted that of Rouvier's cabinet in 1887 , although this was caused not by the vote of an order of the day, but by the refusal of the Chamber to postpone the debate on an interpellation, and although the cabinet continued to hold office for a few days pending the resignation of President Grévy. 
Perier's ministry in May, I 894 - had no such broad significance. Moreover, the production of actual cabinet crises is by no means the whole evil caused by interpellations. The enfeebling of the authority of the ministers by hostile votes about affairs on which they do not feel bound to stake their office is, perhaps, an even more serious matter, for no cabinet can retain the prestige that is necessary to lead the chambers in a parliamentary government, if it is to be constantly censured and put in a minority even in questions of detail. The ministers are not obliged, it is true, to answer interpellations, ${ }^{1}$ but unless some reason of state can be given for refusing, such as that an answer would prejudice diplomatic negotiations, a refusal would amount to a confession of error, or would indicate a desire to conceal the fact, and would weaken very much the position of the cabinet.

The large part that interpellations play in French politics is shown by the fact that they arouse more popular interest than the speeches on great measures; ${ }^{2}$ and, indeed, the most valuable quality for a minister to possess is a ready tact and quick wit in answering them. ${ }^{3}$

The first two institutions referred to as not in harmony with parliamentary government - that is, the method of electing deputies and the sys' . " of committees in the chambers - have real merit. Both tend to check the tyranny of party, and under a form of government where the existence of two great parties was not essential, they might be very valuable. But, except in a despotism, the interpellation followed by a motion expressing the judgment of the Chamber is a purely vicious institution. It furnishes the politicians with an admirable opportunity for a display of parliamen-

1 Poudra et Pierre, $\$$ I 555 .

2 Simon, Nos Hommes d'Elat, p. 27.

${ }^{3}$ Simon, Dieu, Palric, Liberlé, p. 379. 
tary fireworks; but it is hard to see how, under any form of popular government, it could fail to be mischievous, or serve any useful purpose that would not be much better accomplished by a question followed by no motion and no vote. The plausible suggestion has been made that the administration, being free from supervision by the courts of law, can be brought to account for its acts only in this way; ${ }^{1}$ but surely the same result could be as well accomplished by the simpler process of the question, and it is hard to see any reason for imperiling the existence or the prestige of the cabinet to rectify some matter of trifling consequence.

\section{Jealousy and Distrust of the Ministers}

The practice arose from the fact that, owing to the immense power of the executive in France, and the frequency with which that power has been used despotically, the legislature has acquired the habit of looking on the cabinet officers as natural enemies, to be attacked and harassed as much as possible. ${ }^{2}$ But such a view, which is defensible enough when the ministers are independent of the parlia-

1 See Vicomte d'Avenel, "La Réforme Administrative - La Justice," Revue des Deux Mondes, June I, I889, pp. 595-596.

2 M. Dupriez, in the work already cited (ii. 253 et seq.), has explained the strength of this feeling by a most valuable study of the history of the relations between the ministers and the legislature in France. He points out that it existed at the outbreak of the Revolution, for the cahiers or statements of grievances prepared by the meetings of electors held to choose members of the States General in I 789 express a widespread dislike and distrust of all ministers as such. He then shows how the Constituent Assembly tried to curtail the power of the ministers, and reduce their functions to a simple execution of its own orders. It is unnecessary here to follow the subject in detail. It is enough to remark that a large part of the political history of France since the Revolution is filled with struggles for power between the executive and the legislature, in which the former has twice won a complete victory, and deprived the representatives of the people of all influence in the state. Under these circumstances the suspicion and jealousy of the cabinet shown by Liberal statesmen is not surprising. 
ment, becomes irrational when they are responsible to it, and bound to resign on an adverse vote.

Strange as it may seem, the development of interpellations has coincided very closely with that of parliamentary government; ${ }^{1}$ and, in fact, the French regard the privilege as one of the main bulwarks of political liberty. It is this same feeling of antagonism to the government that has given rise to the overweening power of the committees in the Chamber, and their desire to usurp the functions of the ministers. The extent to which this fecling is carried by the Radicals is shown by the proposal made some years ago tc divide the whole Chamber into a small number of permanent grand committees, such as existed in 1848 , in order to bring the ministers even more completely under the control of the deputies; the ideal of the Extreme Radicals being the revolutionary convention, which drew all the powers of the state as directly and absolutely as possible into its own hands. ${ }^{2}$ The less violent Republicans are, no doubt, very far from accepting any such ideal, but still they cannot shake out of their minds the spirit of hostility to the administration which has been nurtured by long periods of absolute rule. They fail to realize that when the ministry becomes responsible to the deputies, the relations between the executive and the legislature are radically changed. The parliamentary system requires an entire harmony, a cordial sympathy, and

1 The practice was first regularly established at the accession of Louis Philippe, the period when cabinets became thoroughly responsible to the Chamber; and it was freely used during the Republic of ${ }_{1} S_{4} S$. After the Coup d'Etat it was, of course, abolished; but toward the end of his reign Napoleon III, as a part of his concessions to the demand for parliamentary institutions, gradually restored the right of interpellation. Finally, under the present Republic the right has been used more frequently than ever before. See Poudra et Pierre, \$\$ I544-I549; Dupriez, ii. 305, 317-31 S.

2 Cf. De la Berge, "Les Grands Comités Parjementaires," Revue des Deux Mondes, Dec. I, I889. 
a close coöperation between the ministers and the Chamber; and to the obligation on the part of the cabinet to resign when the majority withdraws its approval, there corresponds a duty on the part of the majority to support the ministers heartily so long as they are retained in office. Parliamentary government, therefore, cannot be really successful in France until a spirit of mutual confidence between the cabinet and the Chamber replaces the jealousy and distrust that now prevail.

A comparison of the political history of France and England during corresponding years shows to what extent the French procedure has interfered with discipline and disintegrated the parties. In England the Liberals came into power after the elections of 1892 with a small majority in the House of Commons; and, although the supporters of the government were far from harmonious, were, in fact, jealous of each other and interested in quite different measures, the perfection of the parliamentary machinery enabled the ministers to keep their followers together and maintain themselves in office for three years. In France, on the other hand, the elections of 1893 produced a majority which, if even smaller, was far more homogeneous; and indeed, if we compare the position of some of the outlying groups with that of certain sections of the English Liberal party, it is fair to say that the majority in France was both larger and more homogeneous. Yet within two years this majority suffered three cabinets which represented it to be overthrown on interpellations about matters of secondary importance, and finally became so thoroughly disorganized that it lost control of the situation altogether. 


\section{Results of the Condition of Parties}

We have surveyed some of the causes of the condition of political parties in France. Let us now trace a few of its results. In the carlier years, the presence of the Reactionaries deprived cabinet crises of the significance they might otherwise possess. The defeat of the ministers did not mean the advent to power of a different party, because there was no other party capable of forming a cabinet - not the Reactionaries, for they were irreconcilable and hostile to the Republic, and of late years have been far too few in numbers; nor those Republicans who helped the Right to turn out the ministers, because by themselves they did not constitute a majority of the Chamber. Although the Reactionaries have now practically disappeared the condition of the groups is still such that a new cabinet is obliged to seek its support mainly in the ranks of the defeated minority, and hence is usually formed from very much the same material as its predecessor. In fact, a number of the old ministers have generally kept their places, at most an attempt being made to gain a little more support from the Right or Left by giving one or two additional portfolios to the Moderates, Radicals, or Socialists. ${ }^{1}$

When a ministry falls, the parliamentary cards are shuffled, a few that have become too unpopular or too prominent are removed, and a new deal takes place. So true is this, that out of the twenty-four ministries that succeeded each other from the time President MacMahon appointed a Republican cabinet in 1877 until 1897 , only three contained none of the retiring ministers, the aver-

1 Lebon, France as It Is, p. 94. 
age proportion of members retained being about twofifths. ${ }^{1}$

Now, the fact that the fall of the cabinet does not involve a change of party has two important effects: by removing the fear that a hostile opposition will come to power, it destroys the chief motive for discipline among the majority; ${ }^{2}$ and by making the Chamber feel that a change of ministers is not a matter of vital consequence, it encourages that body to turn them out with rash indifference. The result is that the cabinets are extremely short-lived; during the forty years between I875 and I9I4 there were fifty of them, so that the average duration of a French cabinet has been a little less than ten months. ${ }^{3}$ The same fact explains, moreover, the persistence of the system of interpellations, for if a change of ministry does not imply a different programme, there is no self-evident impropriety in overthrowing a cabinet on a question that does not involve a radical condemnation of its policy.

\section{The Cabinet a Coalition and therefore Weak}

The subdivision of the Republican party into separate groups has also an important bearing on the character of the ministry. Instead of representing a united party, the cabinet must usually rely for support on a number of these groups, and the portfolios must be so distributed as to conciliate enough of them to form a majority of the Chamber. ${ }^{4}$

${ }^{1}$ Cf. Haucour, Gouv. et Min.; Muel, Gouv., Min. et Const.; Dupriez, ii. 338 , 343. The thrce exceptions were the cabinets of Brisson in 1885 , Bourgeois in 1895 , and Méline in 1896 .

${ }^{2}$ This is very clearly pointed out by Dupriez, Les Ministres, ii. 390.

${ }^{3}$ I have not counted the reappointment of the Dupuy ministry on the election of Casimir-Perier to the presidency as the formation of a new cabinet.

4 Only on two or three occasions has the cabinet been supported by a group which has contained by itself anything like a majority of the deputies. 
As a rule, therefore, the cabinet is in reality the result of a coalition, and suffers from the evils to which bodies of that kind are subject. The members tend to become rivals rather than comrades, and each of them is a little inclined to think less of the common interests of the cabinet than of his own future prospects when the combination breaks up. ${ }^{1}$ Such a government, moreover, is essentially weak, for it cannot afford to refuse the demands of any group whose defection may be fatal to its existence. ${ }^{2}$ 'The ministers are not at the head of a great party that is bound to follow their lead, and yet they must secure the votes of the Chamber or they cannot remain in office. Hence they must seek support as best they may, and as they cannot rule the majority, they are constrained to follow it ${ }^{3}$ or rather they are forced to conciliate the various groups, and, as the members of the groups themselves are loosely held together, they must grant favors to the individual deputies in order to secure their votes. This is not a new feature in French politics. It is said that during the reign of Louis Philippe, the government kept a regular account with each deputy, showing his votes in the Chamber on one side, and the favors he had been granted on the other, so that he could expect no indulgence if the balance were against him. ${ }^{4}$ Nor has the cause of the evil changed. It is the same under the Third Republic that it was under the Monarchy of July, for in both cases the lack of great national parties with definite programmes has made the satisfaction of local and personal interests a necessity.

a Cf. Dupriez, ii. 348-349. Iebon, France as It Is, p. 85 , speaks of the never-ending struggles for mastery within the cabinet.

2 Cf. Dupriez, ii. $347-348,434-435$.

3 Cf. Simon, Nos Hommes d'Etat, ch. vii, p. iii.

- Hello, Du Régime Constitutionnel, quoted by Minghetti, I Parliti Politici, P. Ior; and see G. Lowes Dichinson, Revolution and Reaction in Modern France, pp. II8-120. 


\section{Political Use of Offices}

We are, unfortunately, only too familiar in this country with the doctrine that to the victors belong the spoils. In France we find the same thing, although it has not been acknowledged so openly, and has been disguised under the name of epuration, or the purification of the administration from the enemies of the Republic. The practice of turning political foes out of office and substituting one's friends seems to have begun during President MacMahon's contest with the Chamber, when the Reactionary party dismissed a large number of officials who had served under former cabinets. ${ }^{1}$ After the Right had been overthrown in 1877 , there arose a cry that the Republic ought not to be administered by men who did not sympathize with it, and would naturally throw their influence against it; but although the fear of danger to the form of government was no doubt genuine at first, the cry became before long an excuse for a hunt after office. $^{2}$ In speaking of this subject, however, it must be remembered that France is not divided into two great parties which succeed each other in power, and hence a wholesale change of public servants, such as has often taken place after a presidential election in the United States, does not occur. The process is continuous, but slower and less thorough. On the other hand, the evil in France is by no means limited to office-seeking, for owing to the immense power vested in the government, the favors which the deputies demand and exact as the price of their votes extend over a vast field. Nor do they show any false modesty about making their desires

1 See Channes, pp. 18-19, 231-232.

2 See the remarkable little book by Edmond Scherer, La Démocratie et la France; Channes, Nos Fautes (passim); Simon, Nos IIommes d'Etat, pp. II 4-II5, and ch. vi, p. ii; Dupriez, ii. 502-509; Lamy, La République en $I_{883}$, pp. 6-8, 22; and see a highly colored account by Hurlbert, "The Outlook in France," Forlnightly Review, lv. 347. 
known. They do not hesitate to invade the executive offices, and meddle directly in the conduct of affairs. ${ }^{1}$ Even the prefect, who has the principal charge of local administration, is not free from their interference. He is liable to lose his place if he offends the Republican deputies from his department, and is therefore obliged to pay court to them and follow their lead. In short, the prefect has become, to a great extent, the tool of the deputies; and his dependence is increased by the fact that nowadays he does not usually remain in office long enough to acquire a thorough knowledge of the local wants, or to exercise a strong personal influence. I do not mean that he has become corrupt; far from it. The level of integrity among French officials appears to be extremely high, and though wedded to routine, their efficiency is great; ${ }^{2}$ but the discretion in their hands is enormous, and in using it they must take care not to displease his Majesty the Deputy. ${ }^{3}$

\section{Deputies and their Committees}

Of course the deputies do not wield this immense influence to forward their own private ends alone. They are representatives, and must use their position for the benefit of the persons they represent. But whom do they represent? The people at large? No representative ever really does that. So far as he is actuated by purely conscientious motives he represents his own ideas of right, and for the rest he represents primarily the men who have elected him, and to whom he must look for help and votes in the next campaign. In some countries this means the party, and those

1 Dupriez, ii. 435, 507-508; Channes, pp. 253-256; Lamy, pp. 21-26; Laffitte, Le Suffrage Universel, pp. 54-59.

2 Simon, "Stability of the French Republic," The Forum, x. 383 .

${ }^{3}$ Cf. Channes, Letter of Oct. I, I 884 ; Laffitte, pp. 56-58; Dupriez, ii. $471-472,506-509$. 
classes that hang on the skirts of the party and may be prevailed upon to fall into line. But in France there are no great organized parties, and hence we must consider how candidates are nominated there. The government, at the present day, does not put forward official candidates of its own, as was commonly done during the Second Empire; ${ }^{1}$ and, indeed, it is not supposed to take an active part in elections. This last principle is not strictly observed, for the administrative officials at times exert no little influence in important campaigns, and the government is said to have spent a good deal of money to defeat Boulanger in 1889 . Still there is nothing resembling the control of elections under Napoleon III, and especially there is no interference with the selection of candidates, this matter being left to the spontaneous movement of the voters themselves. The usual method of proceeding is as follows: a number of men in active politics in a commune, or what we should call the wire-pullers, form themselves into a self-elected committee, the members usually belonging to liberal or semi-liberal professions, and very commonly holding advanced views which are apt to go with political activity in France. The committees or their representatives meet together to form an assembly, which prepares the programme, nominates the candidate, and proclaims him as the candidate of the party. ${ }^{2}$ These self-constituted committees, therefore, have the nomination entirely in their own hands; ${ }^{3}$ and, except in the

1 Simon, Dieu, Patrie, Libertê, p. 372.

${ }^{2}$ Simon, Nos Hommes d'Etal, pp. 17-25; Scherer, La Démocratie et la France, pp. 22-24; Reinach, La Politique Opportuniste, pp. 186-188; Laffitte, op. cit., pp. 64-69.

${ }^{3}$ Since the system of scrutin de liste has been given up and the single electoral districts have been reēstablished, the matter is said to have become somewhat more simplified. It is stated that the nominating committees are now formed, at least in many cases, without any meeting of delegates from the communes; and that their function lies not in the selection 
larger cities, a candidate owes his position largely to local influence and personal interests. ${ }^{1}$ Sometimes he has won prominence by a clever speech at a local meeting. Sometimes he has earned gratitude by services rendered in his profession, or otherwise. ${ }^{2}$

After the candidate is nominated, his first care is to issue his programme, and under the system of single electoral districts, each candidate, as has already been observed, has a separate programme, which expresses only his particular views. The active campaign is carried on by means of placards posted on walls and fences, which make a great show, but win few votes; and what is far more effective, by means of newspapers and the stump. ${ }^{3}$ The stump, curiously cnough, is used very little except by the candidates themselves, ${ }^{4}$ who constantly speak at political rallies, of late years frequently holding joint debates. ${ }^{5}$

It is a common saying that if the committees want anything they exert a pressure on the deputy, who in his turn of a candidate, but rather in helping the candidate in whose behalf they have been organized, and acting as his sponsors. (See Alfred Naquet, "'The French Electoral System," North American Review, clv. 466. But see Charles Benoist, "De l'Organization du Suffrage Universel," Revue des Deux Mondes, July 1, 1895, pp. 15-20.) However this may be, the close relations between the deputy and a small self-constituted clique of local politicians, which is the essential point in the French electoral system, remains very much the same.

1 Simon, Nos Hommes d'Etat, pp. 24-25.

2 Chaudordy, La France en 1889 , p. 96.

3 Alfred Naquet, "The French Electoral System," North American Review, clv. 468-470.

4 Theodore Stanton, supplement to the article of Alfred Naquet, p. 473.

5 Alfred Naquet, $I b$. The newspapers at election time are full of accounts of these meetings for joint debate, called Réunions publiques contradictoires. Direct bribery of voters, though not unknown, seems to be rare, but the complaint that elections have been getting a good deal more expensive of late years is general. Naquet, $I b$.; Reinach, Pp. I $\$ 9^{-I} 90$; Simon, Dieu, Patrie, Liberté, p. 373; Sowviens toi du Deux Décembre, p. gr. 
brings a pressure to bear on the ministers; and hence it has been a common saying that the electoral committees rule the deputies, and the deputies rule the government. ${ }^{1}$

\section{The Deputies and their Constituents}

It is asserted that, since the reintroduction of single electoral districts, the power of the committees has sensibly diminished, ${ }^{2}$ and, whether this be true or not, it is certainly easy to exaggerate their influence, for the deputy must always consider other people besides the wire-pullers. He must try to strengthen his general popularity throughout his district. He is, indeed, expected to look after the political business of his constituents, and is a regular channel for the presentation of grievances and the distribution of favors; one of the complaints most commonly heard in France being that the deputies represent local and personal interests rather than national ones. But even this does not end his responsibilities. The traditions of centralization which make all France look to Paris for guidance, and the habit of paternal government that makes men turn to the state for aid, have caused many people to regard the deputy as a kind of universal business agent for his district at the capital, and burden him with all sorts of private matters in addition to his heavy public duties. Sometimes this is carried to an extent that is positively ludicrous. Some years ago a couple of deputies gave an account at a public dinner of the

${ }^{1}$ Channes, Nos Fautes, pp. $238-239$; and see Scherer, La Démocratie et la France, p. 27; Simon, Dieu, Palrie, Liberté, p. 378.

For this reason one frequently hears it said that the deputies do not see the real people, but only their own political dependents. Channes, p. 38 ; Simon, Souviens toi du Deux Décembre, pp. I65-166.

2 Naquet, "The French Electoral System," North American Review, clv. 466. But see on the other side the article of Benoist in the Revue des Deux Mondes, July I, I895, pp. I7-I9. 
letters they had received from their districts. Some constituents wanted their representative to go shopping for them; others asked him to consult a physician in their behalf; and more than one begged him to procure a wet nurse, hearing that this could be done better in Paris than in the provinces. ${ }^{1}$ Is it to be wondered that the French deputy should bend under the weight of his responsibilities?

If I seem to have drawn a somewhat dark picture of the position of the deputy, I do not want to be understood as implying that all deputies are alike; that many of them are not men of high character, who will not yield to the temptation and pressure with which they are surrounded. My object is simply to describe a tendency; to point out a defect in the French political system, and to show clearly the characteristic evils which that defect cannot fail to develop. The famous scandals about the bribery of deputies in connection with the Panama Canal, with which the newspapers were filled for three months, cast a dismal light over public life in France, and although at first the credulous no doubt exaggerated the extent of the corruption, still there was fire enough under the smoke to show what baleful influences haunt the corridors of the Palais Bourbon.

\section{Prospects of the Republic}

Before closing, let us consider for a moment the political prospects of the country. The generous enthusiasm that greeted the Republic at the outset has faded away, and even its most ardent advocates have found to their sorrow that it has not brought the promised millennium. Such a feeling of disappointment is not surprising. On the contrary, it might have been surely predicted, for in every form of government that has existed in France since the Revolution the period

1 This is quoted by Scherer in La Démocratic et la France, pp. 34-35. 
of enthusiasm has been followed by one of disenchantment, and to this latter stage the Republic has come in the natural course of events. Now this period may well be looked upon as crucial, because as yet no form of government in France has been able to live through it. After a political system has lasted about half a generation, the country has always become disgusted with it, torn it down, and set up another - a course that has made any steady progress in public life impossible. The effect has, in fact, been very much like that which would be produced by a man who should constantly root out his crops before they came to maturity, and sow his field with new and different seed.

The reason for such a state of things is not hard to find. Since the Revolution every form of government in France has been the expression or outward sign of a definite set of political opinions. So close, indeed, has the connection been between the two, that it has been impossible for men to conceive of one without the other, and therefore a fundamental change of opinion has always involved a change in the form of government. Any one who studies the history of the nation will see that there has never been a change of party without a revolution. There has often been a shifting of control from one group to another of a slightly different coloring, but the real party in opposition has never come to power without an overturn of the whole political system. Under the Restoration, for example, the ministers were sometimes Moderate and sometimes extremely Reactionary, but were never taken from the ranks of the liberal opposition. Again, during the Monarchy of July the different groups of Liberals disputed fiercely for the mastery, but neither the Radicals nor the Reactionaries had the slightest chance of coming to power. If space permitted, this truth might be illustrated by taking up in succession each of the 
governments that have flourished since the Revolution, but perhaps it is enough to refer to the only apparent exception that has occurred. While General MacMahon was President of the Third Republic, power was certainly transferred from the Reactionaries to the Republicans, but the circumstances of this case were very peculiar. 'The Republic had hardly got into working order, and the struggle of the Reactionaries may be looked upon as a final effort to prevent it from becoming firmly established. The French themselves have always considered the occurrence, not as a normal change of party, but as the frustration of an attempt at a coup d'état or counter-revolution. This case, therefore, from the fact that it has been generally regarded as exceptional, may fairly be treated as the kind of exception that tends to prove the rule. A revolution in France has corresponded in many ways to a change of party in other countries, but with this grave disadvantage, that the new administration, instead of reforming the political institutions, destroyed them altogether. Of course such a method put gradual improvement out of the question, and before the nation could perfect her government she had to learn that the remedy for defects is to be sought through the reform, not the overthrow, of the existing system.

One would suppose that under the Republic no such difficulty could arise, because a republic means the rule of the majority, and the majority is sure to be sometimes on one side and sometimes on the other. But this is not the view of most French Republicans, and especially of the Radicals. These men, recognizing that, on account of a want of training in self-government, the people can be cajoled, or frightened, or charmed, or tricked into the expression of the most contradictory opinions, refuse to admit that any vote not in harmony with their own ideas can be a fair test of the popu- 
lar will, and assume for themselves the exclusive privilege of declaring what the people really want. As M. Edmond Scherer has cleverly said: "Let us add that the God (universal suffrage) has his priests, whose authority has never been quite clear, but who know his wishes, speak in his name, and, if resistance occurs, confound it by an appeal to the oracle whose secrets are confided to them alone." 1 The Radicals, therefore, cannot admit a possibility that the true majority can be against them, and nothing irritates them so much as to hear the other parties claim that the people are on their own side. It has been said that the Republic will not be safe until it has been governed by the Conservatives, ${ }^{2}$ and the remark has a special significance in this connection. It meant that, until the Conservative elements come to power, it would not be clear whether the Republic has enough strength and elasticity to stand a change of party without breaking down. It meant also that the right of the majority to rule, which is the ultimate basis of the consensus on which the Republic must rest, would not be surely established until each party has submitted peaceably to a popular verdict in favor of another.

As the Republic grows older, the form of its institutions will no doubt be gradually modified, but, whatever changes take place, one thing is clear: the responsibility of the ministers to parliament must be retained. In a country like the United States, where power is split up by the federal system, where the authority in the hands of the executive is comparatively small, and, above all, where the belief in popular government and the attachment to individual liberty and the principles of the common law are ingrained in the race,

1 La Démocralie el la France, p. 18.

2 "La République et les Conservateurs," Revue des Deux Mondes, March I, I890, pp. I 20-I 21 . This means, of course, the conservative element among the people, and not merely the conservative Republicans. 
there is no danger in entrusting the administration to a president who is independent of the legislature. But this would not be safe in France, because, owing to the centralization of the government and the immense power vested in the executive, such a president would be almost a dictator during his term of office; and the temptation to prolong his authority, from public no less than from selfish motives, would be tremendous. And, in view of the tendency of the mercantile classes, and even of the peasants, to crave a strong ruler, it might not be difficult for him to do so, as Louis Napoleon proved long ago. He was able to overthrow a popular assembly because the French had long been accustomed to personal government, and because an assembly was incapable of maintaining a stable majority; because, in short, the French knew how to work personal but not representative government: and the danger will continue until parliamentary institutions are perfected, and their traditions by long habit have become firmly rooted. The French president cannot, therefore, be independent, and the only feasible alternative is to surround him with ministers who are responsible to the Chamber of Deputies. But if the parliamentary system must be retained, it is important to remove the defects that it shows to-day, and especially is it necessary, on the one hand, to diminish the autocratic power of the administration, which offers a well-nigh irresistible temptation to both minister and deputy; and, on the other hand, to give the cabinet more stability, more dignity, and more authority; to free it from the yoke of the groups in the Chamber; to relieve it from the domination of irresponsible committees, and from the danger of defeat by haphazard majorities; to enable it to exert over its followers the discipline that is required for the formation of great, compact parties; to make it, in short, the real head of a majority in parliament and in the nation. 
That the Republic will endure no one will now doubt. The conduct of the nation during its heroic struggle in this war seems to prove it beyond all question. But that the methods of operating the republican government are defective no one is more keenly aware than the French themselves. Their criticism of the evils of politics have been incisive; and in fact the very disenchantment which the Republic has brought, the loss of faith in regeneration by any form of government, has not been without its value. If political idealism has faded into the light of common day this has had a bracing effect upon the national character, a sobering, invigorating influence which could be perceived even before this war revealed it to the world. The French people are more serious, more earnest, of a finer and deeper nature than their parliamentary life suggests. The imperfections in the government have been largely due to the fact that the Republic was at the outset an experiment, surrounded, as they believed, by uncertainty and perils which with growing stability have vanished into the past. When peace returns such genius can hardly fail to remove them, relying upon the confidence the people have acquired in their own national force, in one another, and in the capacity for common action which their achievements in this war have made clear. 


\section{CHAPTER VIII}

\section{ITALY}

THE perfection of its organization and the excellence of its laws preserved the life of Rome long after its vital force had become exhausted; and when the"Teutonic tribes had once broken through the shell of the western empire, they overran it almost without resistance. Europe sank into a state of barbarism, from which she recovered to find her political condition completely changed. Slowly, during the Middle Ages, the nations were forming, until at last Europe became divided into separate and permanent states, each with an independent government of its own. In two countries, however - Italy and Germany - this process of development was delayed by the existence of the Holy Roman Empire, which claimed an authority far greater than it was able to wield, and, while too weak to consolidate its vast dominions into a single state, was strong enough to hinder them from acquiring distinct and national governments. The condition of Italy was further complicated by the presence of the Pope; for although the papacy was an immense civilizing force in mediæval Europe, yet the constant quarrels of the Pope and the Emperor, and the existence of the States of the Church, tended greatly to prevent the development of Italy as a nation. The country was broken into a multitude of jarring elements, and even Dante saw no hope of union and order save under the sway of a German emperor. The north of Italy was full of flourishing cities enriched by commerce and manufactures and resplendent with art, but constantly fighting with each 
other, and, except in the case of Venice, a prey to internal feuds that brought them at last under the control of autocratic rulers. ${ }^{1}$ The south, on the other hand, fell under the dominion of a series of foreign monarchs, who were often despotic, and, by making the government seem an enemy of the governed, destroyed in great measure the legal and social organization of the people. For thirteen centuries from the reign of Theodoric the Ostrogoth to the time of Napoleon - the greater part of Italy was never united under a single head; and in both of these cases the country was ruled by foreigners. Yet, short-lived and unnatural as the Napoleonic kingdom of Italy was, it had no small effect in kindling that longing for freedom and union which was destined to be fulfilled after many disappointments.

By the treaty of Vienna, in I8I5, Italy was again carved into a number of principalities, most of them under the direct influence of Austria. Most of them, but not all, for in the northwestern corner of the peninsula, between the mountains and the sea, lay Piedmont, ruled by a prince of the house of Savoy, with the title of King of Sardinia. During the great popular upheaval of 1848 , Charles Albert, a king of this line, granted to his people a charter called the Statuto, and in that year and the following he waged war with Austria for the liberation of Italy. $\mathrm{He}$ was badly beaten, but succeeded in attracting the attention of all Italians, who now began to look on the King of Sardinia as the possible savior of the country. After his second defeat, at Novara, on March 23, I849, Charles Albert abdicated in favor of his son, Victor Emmanuel, who refused to repeal the Statuto in spite of the offers and the threats of Austria - an act that won for him the confidence of Italy and the

1 Genoa was torn with factions, and was at times, though not permanently, subject to Milan or to France. 
title "Il Re Galantuomo," the King Honest Man. 'The reliance, indeed, which Victor Emmanuel inspired was a great factor in the making of Italy; and to this is due in large part the readiness with which the Italian revolutionists accepted the monarchy, although contrary to their republican sentiments. In fact, the chivalrous nature of the principal actors makes the struggle for Italian unity more dramatic than any other event in modern times. ${ }^{1}$ The chief characters are heroic, and stand out with a vividness that impresses the imagination, and gives to the whole history the charm of a romance. Victor Emmanuel is the model constitutional king; Cavour, the ideal of a cool, far-sighted statesman; Garibaldi, the perfect chieftain in irregular war, dashing, but rash and hot-headed; Mazzini, the typical conspirator, ardent and fanatical; - all of them full of ardor and devotion. The enthusiasm which they inspired went far to soften the difficulties in their path, and to help the people to bear the sacrifices entailed by the national regeneration. Over against these men stands Pius IX, who began his career as a reformer, but, terrified by the march of the revolution, became at last the bigoted champion of reaction. The purity of his character and the subtle charm of his manner fitted him to play the part of the innocent victim in the great drama.

\section{The Union of Italy}

When Cavour first became prime minister of Victor Emmanuel in 1852 , his plan was a confederation of the Italian States under the Pope as nominal head, but practically under the lead of the King of Sardinia. Now, in order to make this plan a success, it was necessary to exclude the

${ }^{1}$ Professor Dicey speaks of this, and draws a comparison between Italian and Swiss politics, in a letter to The Nation, of Nor. 18, 1886. 
powerful and reactionary House of Hapsburg from all influence in the peninsula, and with this object he induced Napoleon III to declare war against Austria in 1859; but when the Emperor brought the war to a sudden end by a peace that required the cession of Lombardy alone, and left Venice still in the hands of the enemy, Cavour saw that so long as Austria retained a foothold in Italy, many of the principalities would remain subject to her control. $\mathrm{He}$ therefore changed his plan, and aimed at a complete union of Italy under the House of Savoy. ${ }^{1}$ The whole country was ready to follow the lead of Victor Emmanuel, and, except for Venice and Rome, which were guarded by foreign troops, the march of events was rapid. The people of the northern states had already risen and expelled their rulers, and early in I860 they declared for a union with Sardinia. Later in the same year Garibaldi landed at Marsala with a thousand men, roused the country, and quickly overran Sicily and Naples, which decided by popular vote to join the new kingdom - a step that was soon followed by Umbria and the marches. The rest of Italy was won more slowly. Venice was annexed in I866, as a result of the war fought against Austria by Prussia and Italy; and Rome was not added until I870, after the withdrawal of the French garrison and the fall of Napoleon III, who had sent it there to protect the Pope.

\section{The Statuto}

It is curious that Sardinia expanded into the kingdom of Italy without any alteration of its fundamental laws, for the Statuto, originally granted by Charles Albert in 1848 , remains the constitution of the nation to-day. It has never

${ }^{1}$ Jacini, I Conservalori e l' Evoluzione dei Partili Politici in Italia, p. 55 et seg. 
been formally amended, and contains, indeed, no provision for amendment. At first it was thought that any changes ought to be made by a constituent assembly, and in 1848 a law was passed to call one, although on account of the disastrous results of the war it never met. By degrees, however, an opinion gained ground that the political institutions of Italy, like those of England, could be modified by the ordinary process of legislation. This has actually been done, to a greater or less extent, on several occasions; and now both jurists and statesmen are agreed that unlimited sovereign power resides in the king and Parliament. ${ }^{1}$ The Statuto contains a bill of rights; but, except for the provision forbidding censorship of the press, and perhaps that protecting the right of holding meetings, ${ }^{2}$ it was not designed to guard against oppression by the legislature, but only by the executive. The Statuto is, in fact, mainly occupied with the organization of the powers of state, and has gradually become overlaid with customs, which are now so strong that many Italian jurists consider custom itself a source of public law. They claim, for example, that the habit of selecting ministers who can command a majority in Parliament has become binding as part of the law of the land. ${ }^{3}$

1 Brusa, Italien, in Marquardsen's Handbuch, pp. I2-I6, I8I-I82; Ruiz, "The Amendments to the Italian Constitution," Ann. Amer. Acad. of Pol. Sci., Sept., I895. It may be noted that the various contributions to Marquardsen's series are of very different value, and that Brusa's is one of the best. He remarks (p. Is) that, beiore changing any constitutional provision, it has been customary to consult the people by means of a general election, and that it is the universal opinion that Parliament has not power to undo the work of the popular votes by which the various provinces were annexed; in other words, that Parliament cannot break up the kingdom. It has been suggested that the courts can consider the constitutionality of a law which involves a forced construction of the Statuto, but this view has not prevailed. (Brusa, pp. I82, note 3, 229-230.)
2 Arts. 28, 32.
3 See Brusa, p. Iو. 
Let us consider the powers of state in turn, beginning with the king and his ministers, then passing to the Parliament, then to the local government and the judicial system, and finally to the position of the Catholic Church.

\section{The King}

At the head of the nation is the king, whose crown is declared hereditary, according to the principles of the Salic law; that is, it can be inherited only by and through males. ${ }^{1}$ It sounds like a paradox to say that the king is a constitutional sovereign, but that the constitution does not give a correct idea of his real functions, and yet this is true. By the Statuto, for example, his sanction is necessary to the validity of laws passed by the Parliament, ${ }^{2}$ but in point of fact he never refuses it. ${ }^{3}$ Again, the constitution provides that treaties which impose a burden on the finances or change the territory shall require the assent of the chambers, ${ }^{4}$ leaving the crown free to conclude others as it thinks best; but in practice all treaties, except military conventions and alliances, are submitted to Parliament for approval. $^{5}$ The king is further given power to declare war, to appoint all officers, to make decrees and ordinances, to create senators, to dissolve the Chamber of Deputies, and so forth; ${ }^{6}$ but the Statuto also provides that no act of the government shall be valid unless countersigned by a minister; and in fact all the powers of the king are exercised in his name by the ministers, who are responsible to the popular chamber. ${ }^{7} \mathrm{He}$ is, indeed, seldom present at cabinet

\footnotetext{
1 Statuto, Art. 2. 2 Statuto, Art. 7.

${ }^{3}$ Brusa, pp. 105, 153; cf. Dupriez, i. 28r, 292-297.

${ }^{4}$ Statuto, Art. 5.

5 Brusa, p. 106.

${ }^{6}$ Statuto, Arts. 5-9.

7 Statuto, Art. 67; and see Brusa, p. 105.
} 
meetings, and has little or no direct influence over current domestic politics, ${ }^{1}$ although it is said that his personal opinion has a good deal of weight on the relations with foreign states. ${ }^{2}$ When, however, a cabinet crisis occurs and the ministry resigns, the king has a great deal of latitude in the appointment of its successor; for the Chamber is not divided into two parties, one of which naturally comes into power when the other goes out, but, as in France, it is split up into a number of small groups, so that every ministry is based upon a coalition. The king can, therefore, send for almost any one he pleases and allow him to attempt to form a cabinet. It often happens, moreover, that the man selected feels that he cannot get the support of a majority in the existing Chamber, but, hoping for a favorable result from a new election, is willing to undertake to form a cabinet if allowed to dissolve Parliament. In such cases the king exercises his own discretion, and grants permission or not as he thinks best; for, contrary to the habit in France, dissolutions in Italy are by no means rare. Thus the Italian king, although strictly a constitutional monarch tied up in a parliamentary system, is not quite so powerless as the French president or the English king.

\section{The Ministers}

In the selection of his ministers the king is not limited by law to members of Parliament, but, if a man is appointed who is not a member of either house, he is obliged by custom to become a candidate for the next vacant seat in the Chamber of Deputies, unless he is created a senator. ${ }^{3}$ As

1 Brusa, p. 108 . Dupriez, i. 289 , says that he presides only when peculiarly important matters are under discussion.

2 Dupriez, i. 296 . This is a common opinion.

${ }^{3}$ Brusa, p. I08; and the same thing is true of the parliamentary undersecretaries. Id., p. I96. 
in other parliamentary governments on the Continent, however, the ministers and their undersecretaries have a right to be present and speak in either Chamber, although they can vote only in the one of which they happen to be members. ${ }^{1}$ The work of the Parliament is, indeed, chiefly directed by them; for, while individual members have a right to introduce bills, the power is used only for matters of small importance. ${ }^{2}$ As a rule, each minister has charge of a department of the administration; but it is allowable, and was at one time not uncommon, to appoint additional ministers without portfolios, whose duties consisted solely in helping to shape the policy of the government, and defending it in the chambers. ${ }^{3}$

\section{The Senate}

The Italian Parliament has two branches - the Senate and the Chamber of Deputies. The Senate is composed of the princes of the royal family, ${ }^{4}$ and of members appointed by the king for life from certain categories of persons defined by the Statuto. ${ }^{5}$ These are: bishops; ${ }^{6}$ sundry

1 Statuto, Art. 66; Law of Feb. 12, I888, Art. 2.

2 Brusa, p. I72. Dupriez (i. 308) says that the ministers in Italy have not so complete a monopoly of initiative as in other countries, and that private members often propose measures with success. But in saying this he must not be understood to deny that the laws enacted as a result of private initiative are unimportant compared with the government measures, both as regards number and character.

3 Brusa, p. 197. See, also, the lists of the different ministries published in the Manual of the Deputies. This manual, by the way, is a most valuable production, for it contains the text of many important laws and a large amount of interesting information. For the organization and functions of the various departments, see Brusa, p. 200 et seq.

4 Statuto, Art. 34 .

${ }^{5}$ Statuto, Art. 33. All the appointed members must be forty years old.

${ }^{6}$ Since the quarrel with the Pope in 1870 this class has not been available. Brusa, p. IIg. 
high officials, civil, military, and judicial; ${ }^{1}$ deputies who have served three terms, or six years; ${ }^{2}$ men who have been for seven years members of the Royal Academy of Science; men who pay over three thousand lire (about six hundred dollars) in taxes; ${ }^{3}$ and men deserving exceptional honor for service to the state. Owing to the extreme severity of the Senate in recognizing such desert, there are at present only two members from this last class; for the Senate itself has the strange privilege of deciding whether a person selected by the king belongs properly to one of these classes, and is qualified to be a senator. ${ }^{4}$ Except for money bills, which must be presented first to the Chamber of Deputies, the legislative powers of the two houses are the same, but the Senate has also judicial functions. It can sit as a court to try ministers impeached by the Chamber of Deputies; to try cases of high treason and attempts on the safety of the state; ${ }^{5}$ and to try its own members - the Italians, curiously enough, having copied in their Senate the antiquated privilege which entitles the English peers to be tried for crime only by members of their own body. ${ }^{6}$ As a matter of fact, the Senate has very little real power, and is obliged to yield to the will of the lower house. ${ }^{7}$ In I878-I880 it did, indeed, refuse to abolish the unpopular grist-tax for more than a year, but gave way before a newly

1 Except in the case of the highest officials, persons of this class can be appointed only after a period of service which varies from three to seven years, according to the office they hold. In rgro there were ninety-nine senators from this class.

2 Out of a total of about three hundred and eighty-three, there were in Ig Io about one hundred and forty-seven senators from this class.

3 There were seventy-one senators from this class.

4 Brusa, p. Ir9; and see the Statuto, Art. 60.

${ }^{5}$ Statuto, Art. 36.

${ }^{6}$ Statuto, Art. 37.

7 The changes made by the Senate in bills have usually a legal rather than a political importance. Dupriez, p. 3 I 3 . 
elected Chamber of Deputies. ${ }^{1}$ It would probably not venture even so far to-day, for the number of senators is unlimited, and on several occasions a large batch of members has been created in order to change the party coloring of the body - in I 890 as many as seventy-five having been appointed for this purpose at one time. ${ }^{2}$ As in other countries where the parliamentary system exists, the cabinet is not responsible to the upper house; and it is only occasionally, and as it were by accident, that a minister has resigned on account of an adverse vote in the Senate. ${ }^{3}$

\section{The Chamber of Deputies}

The Chamber of Deputies consists of five hundred and eight members, elected until 19 2 on a limited franchise. By the earlier law, the suffrage was so restricted that less than two and a half per cent of the population were entitled to vote; but this was felt to be too small a proportion, and in 1882 it was increased by an act whose provisions were in force for thirty years. ${ }^{4}$ By this statute a voter must be able to read and write, and must have passed an examination on the subjects comprised in the course of compulsory education, ${ }^{5}$ except that the examination was not required in the case of officials, professional men, graduates of colleges, and others who could, of course, pass it; nor in the case of men who had received a medal for military or civil

1 Brusa, pp. $155^{-1} 5^{6}$. See Petruccelli della Gattina, Storia d' Italia, I $860-1880$, pp. $420-421,55^{8-559}$.

${ }^{2}$ In 1886 forty-one were appointed together, and in 1892 forty-two. See the list of senators with their dates, in the Manual of the Deputies for 1892, p. 806 et seq., and p. 876 .

3 Brusa, p. I58, note 3 .

1 Brusa, pp. 122-127. This law, with its amendments, recodified in 1895 , may be found in full in the Manual of the Deputies for that year.

- Education was compulsory in Italy only between the ages of six and nine. Act of July 15,1877 , Art. 2. 
service, or who paid a direct tax of nineteen and fourfifths lire (about four dollars), or who paid rents of certain amounts. The change more than tripled the number of voters at once; ${ }^{1}$ and, although these still included only a small part of the citizens, it is to be observed that with the spread of elementary education their number was expected to increase until the suffrage became substantially universal. ${ }^{2}$

At first the members were chosen each in a separate district, but after the times of enthusiasm for Italian unity were over, and the generous impulse that had stirred the country began to give way before the selfish motives of everyday life, it was found that the deputies failed to take broad views of national questions, and were largely absorbed by personal and local interests. It was found, in short, that they represented the nation too little and their particular districts too much; ${ }^{3}$ and it was hoped that by increasing the size of the districts they would be freed from the tyranny of local influence, and enabled to form compact parties on national issues. ${ }^{4}$ With this object the Act of 1882 distributed the five hundred and eight seats among one hundred and thirty-five districts, which elected from two to five

1 It raised the number from 627,838 to $2,049,461$. Brusa, p. 127. When the law went into effect, the voters were not very unequally divided into those who passed the examination, those who paid the taxes, and the other excepted classes. Id., p. I 26 , notes I-2.

2 In order to restrict the arbitrary influence of the government over elections, and to prevent the abuses which had been common before, a procedure for preparing the lists of voters and insuring the secrecy of the ballot was established by the same law (see Brusa, pp. 127-I28, 130-132); and in this connection it may be noticed that soldiers and sailors in active service (including subalterns and police officials) are not allowed to vote. Law of March 28, I895, Art. I4.

${ }^{3}$ Brusa, p. 16.

- Minghetti, I Partili Polilici, p. IS; Petruccelli della Gattina, p. 504. 
deputies apiece; ${ }^{1}$ and, in order to give some representation to minorities, it was provided that in those districts which elected five deputies no one should vote for more than four candidates. $^{2}$ The new system, called the scrutinio di lista, did not produce the results that were expected from it. On the contrary, in Italy as in France, where the same remedy was applied to the same evil, the organization and power of the local wirepullers grew with the increase in the number of deputies elected in a district, while the influence of the latter over the ministers and the provincial officers was greater than ever before. ${ }^{3}$ An Act of May 5, r89r, abolished, therefore, the scrutinio di lista and reëstablished single electoral districts.

Finally, in spite of the large number of illiterates, an act was passed on June 30, I9 I 2 , which established very nearly universal manhood suffrage. It extended the right to vote to all men who can read and write, and to those who cannot but who have reached the age of thirty years and have performed their military service. The system of single electoral districts was retained. The act increased the electorate from three millions to about eight millions; and the first elections held under it in the course of the following year showed a distinct tendency toward the more radical groups.

In accordance with the general practice in Europe, the deputies are not required to be residents of their districts, the only important limitations on the choice of candidates being the requirement of the age of thirty years, and the

I Three districts elected two deputies, sixty-one elected three, thirty-six elected four, and thirty-five elected five. Brusa, p. I 29. See Arts. 44 and 45 of the Act of 1882 , and the table of districts annexed thereto.

2 Act of 1882, Art. 65 .

3 Brusa, Ib.; and see Turiello, Governo e Governati in Italia, $2 \mathrm{~d}$ ed.; Fatli, p. 326; Proposte, p. I7I. 
provision excluding priests who have active duties, mayors and provincial counsellors in their own districts, and all officials paid from the treasury of the state with the exception of ministers, undersecretaries, and a few others. ${ }^{1}$ Under the earlier laws the deputies received no pay for attendance, but were given free passes over the railroads, ${ }^{2}$ and it was no doubt partly for this reason that the small attendance in the Chamber was long a crying evil. To remedy this the Act of I9I 2 provided for the payment of the members.

The Chamber is elected for five years, but so far its life has always been cut short by a dissolution, and in fact the average length of term has been less than three years. ${ }^{3}$ The budget and the contingent of recruits are adjusted by annual laws, and there would naturally be a new session every year; but in order not to interrupt the work of Parliament, and especially the consideration of the budget, which is apt to be behindhand, a curious habit grew up of prolonging the sessions, so that three parliaments have had only a single session apiece, one lasting two and a half and another three and a half years, all of them unbroken save by occasional recesses. ${ }^{4}$

The Chamber of Deputies elects its own President and other officers, and the vote for President used to be an

1 Brusa, pp. I32-I34; and see Acts of Dec., I860 (Arts. 97, 98), July 3, 1875, May I3, I877, July 5, I882, March 28, I895 (Arts. 81-89). There is a curious provision that only forty officials of all kinds (except ministers and undersecretaries), and among them not more than ten judges and ten professors, can be deputies at the same time, and if more are elected they are reduced to that number by lot. Law of March 28, r895, Art. 88. On account of some scandals that occurred at one time it is further provided that no officers of companies subventioned by the state, and no government contractors, can sit in the Chamber. Brusa, p. I34; law of March 28, I 895, Arts. $84-85$.

${ }^{2}$ Brusa, pp. I 59-I60.

${ }^{3} I d ., \mathrm{p} .139$.

- Brusa, p. I39; and see the list of the sessions of the various Parliaments in the Manual of the Deputies. 
occasion for a trial of party strength, as in most other legislative bodies. Of late years, however, the English habit has prevailed of reëlecting the same man without regard to party affiliations; ${ }^{1}$ and this is the more striking because the President appoints the committees on rules and contested elections ${ }^{2}$ which have, of course, no little importance. The idea that the presiding officer ought to be strictly impartial is not the only valuable suggestion the Italians have derived from England, for they have inherited Cavour's admiration for British parliamentary procedure, and in general they attempt to follow it. Unfortunately they have not done so in all cases, for the system of committees and of interpellations or questions has been copied mainly from the French and not the English practice.

\section{The Administrative System}

Such, briefly stated, are the position of the king and the composition of the Parliament; but although the king and his ministers on the one hand, and the Parliament on the other, are the great political forces whose interaction determines the character of the government, still it is impossible to appreciate the relations between the two without some knowledge of the method of administration, the principles of local government, and the control exercised by the courts of law, because these matters have a direct bearing on the functions of the cabinet and hence on the nature of the influence exerted upon it by the Parliament.

The administration both of national and local affairs, and to some extent the judicial system of Italy, are modeled

1 Brusa, pp. 140 and $1_{5} 6$, note 2. Biancheri was President of the Chamber continuously from 1884 to 1892 . Manual of the Deputies for 1892 (pp. 800802 ). In that year he was dropped for party reasons, and in fact the practice of looking on the President as the representative of a party has unfortunately revived.

2 Rules of the Chamber of Deputies, Art. I 2. 
on those of France, and they present the defects without all the advantages of the original. This is particularly true of the administrative system, where Italy has copied the centralization, but has been unable to acquire the traditions which give real solidity to the body of officials. At first sight it seems strange that Cavour and his successors, with their admiration for English institutions, should have turned to the French bureaucracy as a pattern; but there were several reasons for their course. In the first place the Napoleonic rule had already made the Italians familiar with the French form of administration. A far stronger motive came from the fact that after Cavour gave up the idea of a confederation, and strove to create a united kingdom of Italy, it became important, in view of the possible interference of foreign powers, to consolidate the different provinces as completely and rapidly as possible. The Italian statesmen tried, therefore, to make the people homogeneous; to remove as far as possible all local differences; and to destroy all possibility of local opposition. ${ }^{1}$ The country, moreover, was very backward, and a great work of regeneration had to be undertaken, especially in the south, where society was badly disintegrated and brigandage was rife. To accomplish this a highly centralized and autocratic system, in which the government could make itself quickly and decisively felt, was thought essential; ${ }^{2}$ and it was believed, not without reason, that until the union was accomplished, and order had been established in Naples and Sicily, it was impossible to introduce general local selfgovernment or universal liberty. The old territorial divisions were therefore swept away, and replaced by artificial districts devoid, of course, of real local life. A centralized

1 See Brusa, pp. 23, 337; Jacini, I Conservalori, p. 55 el seq., Due Anni di Politica Ilaliana, pp. 93-94.

2 See Brusa, pp. 253-254. 
form of administration was set up, and the government was given a highly arbitrary power to interfere with the freedom of the individual. Such a system might have worked very well in the hands of a wise dictator, but, as some of the Italian writers have themselves remarked, it was so entirely inconsistent with the parliamentary form of government that one of them was sure to spoil the other, and experience has shown that both of them have suffered from the combination. ${ }^{1}$

\section{Contrast between Theory and Practice}

There is a marked contradiction in Italy between the theory and practice of government; for there is a strong ambition to be abreast of the times and a general belief in the principle of personal liberty; but the actual condition of the nation has made it impossible to live up to these standards. A striking example of the contrast between aspirations and results is furnished by the state of the criminal law, for capital punishment has been abolished, in spite of the fact that homicide is more common than in . any other civilized country in Europe, ${ }^{2}$ and yet criminal procedure is in such a condition that thousands of people have been arrested on suspicion, kept in prison sometimes for years, and finally released because there was not sufficient ground for trial. ${ }^{3}$ Thus by her code Italy appears to be

${ }^{2}$ Cf. Jacini, I Conservatori, pp. 67-68; Minghetti, I Parti Politici, p. Ioo; Pareto, "L'Italie Economique," Revuc des Deux Mondes, Oct. 15, I89r; and see Bertolini, "I Pieni Poteri per le Riforme Organiche," Nuova Antologia, June I, r894.

2 Turiello, Fatti, pp. $330-332$.

${ }^{3}$ See Speyer, in Unsere Zeit, 1879, i. 576 . Petruccelli della Gattina says (Storia d'Italia, p. 258 ) that in $1876,93,444$ persons were arrested on suspicion and let off because there was no ground for trial. This, it is true, was eleven years before the code was finally enacted; nevertheless it illustrates the contrast between ideals and practice in criminal matters, and in fact in that very year the abolition of the death penalty was voted by the Chamber of Deputies, but rejected by the Senate. 
in advance of most other nations, but in her criminal practice she is really far behind them. The truth is that the successive governments, in view of the unsettled state of the country, have been afraid to place restraints on their own power, and weaken an authority thought necessary for the preservation of order. Of course the result has been a good deal of arbitrary officialism and disregard of the rights of the citizen, ${ }^{1}$ but while this is a misfortune for the north of Italy, extraordinary and autocratic power has at times been indispensable in Sicily and the south. ${ }^{2}$ The impossibility, indeed, of giving effect to the theories of liberty that are constantly proclaimed from every quarter was forcibly illustrated by the only serious attempt that has been made to do so. When Cairoli and Zanardelli became ministers in 1878 they tried to carry out their principles thoroughly. They permitted the constitutional right of public meeting to be freely exercised, and gave up the despotic practice of preventive arrest, trusting to the courts to punish offenders against the law; but brigandage increased so fast, and other disturbances became so alarming, that the cabinet was driven from office, and its policy was abandoned. In later years Zanardelli has again held office, and succeeded in improving the administrative and judicial system to some extent, but the progress of the reform has been extremely slow, and the arbitrary power of the government, although reduced, still conforms even in quiet times far more nearly to French than to Anglo-Saxon notions.

\section{The Ordinance Power}

There are two matters in connection with the administration that require special notice. One of them is the power of the executive officials to make ordinances. This is even
${ }^{1}$ Cf. Brusa, p. 183.
${ }^{2}$ Cf. Speyer, in Unsere Zeit, 1879 , i. 58 r. 
more extensively used than in France, and there are complaints that it is sometimes carried so far as to render the provisions of a statute nugatory, ${ }^{1}$ although the constitution expressly declares that " the king makes the decrees and regulations necessary for the execution of the laws, without suspending their observance or dispensing with them." 2 The interpretation put upon this provision is in fact so broad that the government is practically allowed to suspend the law subject to responsibility to Parliament, and even to make temporary laws which are to be submitted to Parliament later - a power that is used when a tariff bill is introduced, to prevent large importations before the tariff goes into effect. ${ }^{3}$ The Parliament has, moreover, a habit of delegating legislative power to the ministers in the most astonishing way. In the case of the Italian criminal code, for example, the final text was never submitted to the chambers at all, but after the subject had been sufficiently debated, the government was authorized to make a complete draft of the code, and then to enact it by royal decree, harmonizing it with itself and with other statutes, and taking into account the views expressed by the chambers. The same was true of the electoral law of 1882 , of the general laws on local government and on the Council of State, and of many other enactments. ${ }^{4}$ It may be added that although

1 Brusa, pp. x $70-172$.

2 Statuto, Art. 6. The courts have power to refuse to apply an ordinance which exceeds the authority of the government, but, in practice, this is not an effective restraint. Brusa, pp. I $7 \mathrm{I}-172, \mathrm{I} 75, \mathrm{I} 87$.

${ }^{3}$ Brusa, pp. 186-187. In 189 i the customs duties on several articles were increased by royal decree, which was subsequently ratified by Parliament.

"Brusa, pp. I75-176; Bertolini, "I Pieni Poteri," Nuova Antologia, June 1,1894 . Several laws of this kind may be found in the Manuals of the Deputies. They are issued in the form not of statutes, but of ordinances, and begin by reciting the legislative authority under which they are made. 
the Statuto does not expressly provide for it, the ministers, prefects, syndics, and other officials are in the habit of making decrees on subjects of minor importance. ${ }^{1}$ The preference indeed for administrative regulations, which the government can change at any time, over rigid statutes is deeply implanted in the Latin races, and seems to be especially marked in Italy. ${ }^{2}$

\section{The Civil Service}

The other matter referred to as requiring special notice is the civil service. 'The host of officials, who are, unfortunately, too numerous and too poorly paid, ${ }^{3}$ can be appointed or dismissed very much at the pleasure of the government, for although there are royal decrees regulating appointments and removals in many cases, they do not appear to furnish a satisfactory guarantee. ${ }^{4}$ Here, then, is a great mass of spoils, in the distribution of which the politicians take an active part. ${ }^{5}$ Decrees, providing for competitive examinations for admission to the service, are indeed common; and in 1890 a statute, ${ }^{6}$ affecting the officers in the department of public safety, was passed with provisions for

It is a curious fact that Italian statutes vary a great deal, sometimes containing only general principles, and leaving to the government the task of completing them by supplementary regulations, and sometimes going into minute details (Brusa, p. I 7 I). Dupriez, who looks at the matter from a French standpoint, says (i. 336) that in the struggle between the government and the Parliament over the limits of the ordinance power, the government has tried to extend its authority beyond measure, and the Parliament to dispute it even in the matter of organizing the administrative service.

1 Brusa, pp. I88-Igo.

2 Minghetti, pp. 293-294.

3 Brusa, p. 260.

4 Dupriez, i. $337-340$; Brusa, pp. 252-255. For the scope of these decrees, sce p. 26I el seq.

- Brusa, pp. I52-153; and see Dupriez, i. 340-342.

- Law of Dec. $2 \mathrm{I}, \mathrm{I} 890$. 
such examinations, and for preventing removal without the consent of a standing commission. But civil service laws, like all others, depend for much of their effectiveness on the persons who execute them. ${ }^{1}$

\section{Local Government}

Let us look for a moment at the local government. The Italian statesmen had at first a general belief in decentralization, ${ }^{2}$ but the force of circumstances and a repugnance to the idea of federation were so strong that the old territorial divisions, which could alone have furnished a solid basis for a decentralized system, were abandoned, and the whole country was cut up into a series of brand-new districts. These are the provinces, the circondari, the mandamenti, and the communes, ${ }^{3}$ of which the first and the last are the

1 There are two bodies that exercise a considerable control over the government. One of these is the Council of State, which has, however, only an advisory power, except in matters of administrative justice, and in the case of provincial and communal officials whom it protects from arbitrary removal. On this subject see Brusa, p. 212 et seq. The laws of June 2, 1889, which regulate this body, may be found in the Manual of the Deputies for r892, p. 357. The other is the Courts of Accounts (Corte dei Conti), whose members can be removed only with the consent of a commission composed of the Presidents and Vice-Presidents of both, Chambers. It has a limited supervision over the collection of the revenue, and passes finally on pensions and on the accounts of officials, provinces, and communes. It also makes a yearly report to Parliament on the accounts of each ministry; but its most extraordinary function consists in the fact that all decrees and orders which involve the payment of more than 2,000 lire must be submitted to it for registration, and if it thinks them contrary to the laws or regulations it can refuse to register them. It is, indeed, obliged to register them if the Council of Ministers insists upon it, but in that case they must be transmitted to the President of the Chambers together with the opinion of the Corle dei Conti. Law of Aug. 14, 1862, Arts. 14, 18, 19; and see Brusa, pp. 219-224.

2 In 1868 , the Chamber actually voted an order of the day in favor of decentralization. Petruccelli della Gattina, pp. 192-195.

${ }^{3}$ In the provinces of Mantua and Venice the division is somewhat different, but is being brought into accord with the general plan. Brusa, p. 339. 
only ones of great importance. Until the Act of 1888 , the powers conferred on the local bodies were extremely small, and even now they are far from extensive, for the whole system is copied from that of France, and, with some variations in detail, the organization and powers of the French local officers and councils have been followed very closely. ${ }^{1}$ A general description of the local government would therefore consist very largely in a repetition of what has been already said in the first chapter on France; and hence it is only necessary to touch on a few salient points, begging the reader to remember how great a power and how large a share of political patronage this system places in the hands of the central authorities. ${ }^{2}$ At the head of each province, which corresponds to the French department, is a prefect appointed by the king, and directly subject to the Minister of the Interior. Like his French prototype, he is regarded as a political officer, and uses his influence more or less openly at elections. ${ }^{3}$ The chief executive magistrate of the commune is the syndic; who is chosen, like the mayor in France, by the communal council from its own members. In the smaller communes, he was, until 1896 , selected by the king from among the members of the council. As in France, both the provinces and the communes possess

1 For a description of the local government, see Brusa, p. 337 et seq. The full text of the law on the subject was fixed by royal ordinance on Feb. Io, I889, in accordance with the Act of Dec. 30 , 1888 . It was followed by an elaborate ordinance regulating its execution, and on July 7,1889 , and July II, I 894 , by acts amending the law. Manual of Deps., I 895 , pp. $301-394$.

2 In practice the administration appears to be, if anything, even more centralized than in France, owing to the habit on the part of the officials of referring everything to the central government. Jacini, I Conservatori, p. I30; Minghetti, I Partiti Politici, pp. 240-24I.

${ }^{3}$ Brusa, pp. 225, 277. On the eve of the elections in 1892 , forty-six out of the sixty-nine prefects were dismissed or transferred to other provinces, in order to help the government to carry the country. 
elected councils. In Italy they are chosen for six years, one half being renewed every three years; but the suffrage for these bodies was exceedingly restricted, until by the Act of I888 it was extended so as to be somewhat wider, especially as applied to the peasants, than the suffrage for the election of deputies. ${ }^{1}$ The resources of the local bodies are not adequate for the fulfillment of their duties, and this, combined with a love of municipal display, has been the cause of heavy debts, especially in the case of the larger cities, many of which have long been on the verge of bankruptcy. ${ }^{2}$

\section{The Judicial System}

There is one branch of the Italian government which has not been centralized, and that is the judicial system. The lower courts are, indeed, new creations, organized on a symmetrical plan very much resembling the French; but, in order apparently not to offend the bench and bar of the old principalities, the highest courts have been suffered to remain in the more important capitals, so that there are now five independent Courts of Cassation, those of Turin, Florence, Naples, Palermo, and Rome, each of which has final and supreme authority, within its own district, on all questions of ordinary civil law. ${ }^{3}$ The Court of Cassation at

1 The other communal and provincial bodies are the municipal giunta, which is elected by the communal council, and has executive powers; the provincial deputation, which occupies a similar position in the province, and is elected by the provincial council; the prefectorial council, appointed by the central government to assist the prefect; and the provincial administrative giunta, partly appointed and partly elected, which has a certain share in administrative justice, and whose approval is necessary for the validity of some of the most important acts of the local councils. For a list of these acts see the Local Government Law of Feb. Io, I889, Arts. 142, $x 66-x 7 x, x 73$, and 223 .

2 See Brusa, pp. 365-367; Turiello, Proposte, pp. 56, 63-65.

${ }^{3}$ A Court of Cassation is a court of last resort, which considers only errors in law in the decisions of inferior tribunals. 
Rome has, it is true, been given little by little exclusive jurisdiction over certain special matters; ${ }^{1}$ but the ordinary civil jurisdiction is still divided among the five Courts of Cassation, which bear the same relation to each other as the highest state courts in America. ${ }^{2}$ There is no appeal from one to another, and no one of them feels bound to accept the decisions of the others, or to follow them as precedents. One cannot help thinking that this is an unfortunate condition, because there is nothing that tends more completely to consolidate a people, without crushing out local life, than a uniform administration of justice. Italy has, indeed, a series of codes enacted at various times from I865 to I 889 , and covering civil law, civil procedure, commercial law, criminal law, and criminal procedure; but a code alone will not produce uniformity, because there is still room for differences of interpretation, and in fact the Italian Courts of Cassation often disagree, and there is no tribunal empowered to harmonize their decisions. ${ }^{3}$

\section{The Courts and the Officials}

As we have already seen in the case of France, the decision of civil and criminal questions forms only a part of the administration of justice in continental Europe, on account of the distinction drawn between public and private law. ${ }^{4}$

1 These are, conflicts of competence between different courts, or between the courts and the administration; the transfer of suits from one court to another; disciplinary matters; and writs of error in criminal cases, in complaints for violation of election laws, in civil suits against judges, and in questions of taxes and of church property.

${ }^{2}$ For the organization and jurisdiction of the courts, see Brusa, pp. 23I238.

${ }^{3}$ Cf. Spcycr, in Unsere Zeit, I879, i. 576 .

4 Belgium presents an exception, for there the officials can be sued, and the acts of the government can be revicwed by the ordinary courts, as in an Anglo-Saxon country. Cf. Kerchove de Denterghem, De la Responsabilité des Ministres dans le Droit Public Belge. 
In order, therefore, to form a correct estimate of the position of the courts, we must consider their relation to the government, and their power to determine the legality of the acts of public officers. In Italy the prefects, subprefects, syndics, and their subordinates still enjoy the so-called administrative protection, that is, they cannot be sued or prosecuted for their official conduct without the royal consent. ${ }^{1}$ This privilege is generally unpopular, and will no doubt be abolished when the proposed bill on the tenure of office is passed. Meanwhile the benefit of it is claimed more and more frequently, although the permission to proceed appears to be usually granted. ${ }^{2}$ But even when this protection has been taken away, the courts will not have as much authority as in England or America. The reader will remember that the officers of the French government formerly possessed a similar privilege, and were deprived of it after the fall of the Second Empire. He will remember also that the change made very little practical difference, because it was held that the ordinary courts had no power to pass on the legality of official acts, such questions being reserved exclusively for the administrative courts. The result of abolishing the privilege will not be precisely the same on the other side of the Alps, because the problem has been worked out on somewhat different lines, a curious attempt having been made to establish a compromise between the English and the French systems.

\section{Administrative Law}

The subject of administrative law is, indeed, very confused in Italy, and some years ago it was in a thoroughly

1 Law of Feb. 10, 1889, Arts. 8, 139 .

2 Brusa, p. 282; Turiello, Fatti, pp. 210-211. The permission to prosecute is not necessary in the case of offenses against the election laws. Law of Feb. 10, 1889, Art. 100 et seq.; Brusa, pp. 73, 130, note I. 
unsatisfactory condition. When the union was formed, several of the component states possessed administrative courts of their own; but in order to produce uniformity, and also with a view of furnishing the rights of the citizen with a better guarantee, an act of March 20, I865, abolished all these tribunals, and provided that the ordinary courts should have exclusive jurisdiction of all criminal prosecutions and of all civil cases in which a civil or political right was involved, the Council of State being empowered to decide whether such a right was involved or not. ${ }^{1}$ It was not clearly foreseen that this last provision would place in the hands of the govermment an arbitrary power; ${ }^{2}$ but such proved to be the case, for the Council of State, composed as it was at that time of members who could be removed at pleasure, ${ }^{3}$ showed little inclination in disputed cases to recognize that any private rights were involved; and, there being no administrative courts at all, the government had an absolutely free hand as soon as the jurisdiction of the ordinary courts was ousted. ${ }^{4}$ The attempt to place the rights of the citizen more fully under the protection of the ordinary courts than in France had resulted in freeing the officials more completely from all control; for, except when strong political motives come into play, arbitrary conduct on the part of the French officials is restrained by the administrative courts. This state of the law in Italy gave rise to bitter complaints, but it lasted until 1877 , when the decision of conflicts, as they are called, or disputes about

1 Legge sul Contenzioso Administrativo (March 20, I865). See, especially, Arts. I, 2, 3, 13.

2 Perhaps it would be more correct to say that it was not foreseen how this power would be used for party purposes. Minghetti, I Parliti Politici, p. 270 et seq.

3 See Legge sul Consiglio di Stato of March 20, I865, Art. 4.

1 See Brusa, pp. 21 2-213, 247; Minghetti, I Partiti Politici, p. 147 et seq. 
jurisdiction between the administration and the courts, was transferred to the Court of Cassation at Rome. ${ }^{1}$ Still there was no system of administrative justice; and hence, however illegal, and however much in excess of the authority of the official who made it, a decree, ordinance, or other act might be, no redress could be obtained from any tribunal unless it could be shown that an actual legal right was violated. ${ }^{2}$

\section{Administrative Courts}

This omission in the judicial system was finally supplied by the statutes of 1889 and 1890 , which reorganized the Council of State, created a special section of it to act as an administrative court, and conferred an inferior administrative jurisdiction on the provincial giunta. ${ }^{3}$ In order to give the council a considerable degree of independence, it was provided at the same time that the members, whose number is limited, should be retired only on account of sickness and removed only for breach of duty, and in each case only after hearing the opinion of the Council of State itself. ${ }^{4}$ The section which acts as an administrative court enjoys a still greater degree of protection; for it is composed of a president and eight other members selected from among the councillors of state by the king, and of these eight not less than two nor more than four can be changed in any one year, ${ }^{5}$ so that, although the body has not the permanence of a court of law, it is by no means a tool of the government. Except in purely political matters, and in certain questions relating to customs duties and conscription, it has power to

1 Law of March 3I, I877 (Manual of Deps. I892, p. 374).

2 Cf. Brusa, pp. $247-250$.

3 These acts, June 2, I889, and May I, I 890, are printed in the Manual for 1892 , at pp. 357 and 377 .

4 Act of June 2, I889, Art. 4.

- Act of June 2, I889, Art. 8. 
decide whether the acts of the central or local officers are authorized by law, unless some special tribunal or the ordinary courts have jurisdiction. ${ }^{1}$ In brief, therefore, the legality of official acts is determined in civil cases by the ordinary courts when a question of private right, and by the administrative courts when a question only of interest, is involved. The function of the ordinary courts in these cases is, however, strictly limited to the protection of the individual, and does not involve an authoritative declaration of the law, for it is expressly provided that the judgment must be confined to the case at bar, and in that alone is the administration bound by the decision. ${ }^{2}$ This principle is deeply rooted in the jurisprudence of the nation, for the Statuto itself declares that the interpretation of the law in such a way as to be universally binding belongs exclusively to the legislative power. ${ }^{3}$ The Italian, indeed, has a dread of that wholesome form of legislation, judge-made law a prejudice which certainly seems very strange when we consider what a large part of the law of the civilized world, and especially of the law of the Latin races, was developed by means of the edicts of the Roman prætors.

It will be observed that the Italian system of administrative law differs from that of every other nation. According to the English principle, the ordinary courts have jurisdiction in all cases, and the idea of administrative law as an independent branch of jurisprudence is little known. In most of the continental countries, on the other hand, all matters involving the legality of official acts are reserved for a special class of courts, which have exclusive cognizance of those questions which constitute the domain of administrative law; but in Italy both classes of tribunals are called upon to decide the same questions, the ordinary courts being specially empowered to protect legal rights.

1 Id., Art. 24. $\quad{ }^{2}$ Act of March 20, 1865, Art. 4. ' 3 Statuto, Art. 73. 


\section{Weakness of the Judicial System}

As seen on the statute book, the Italian judicial system appears to be very good. It seems to provide the individual with more ample remedies, and a better guarantee against arbitrary conduct on the part of the officials, than can be found in most of the countries of continental Europe. But in fact the judiciary is not strong enough to protect the citizen effectually. This is chiefly due, no doubt, to the absence of those deep-seated traditions that are necessary to give the magistrates a controlling authority over public opinion. It is due also to the existence of the five independent Courts of Cassation, which prevents any one court from having the power that might be acquired by a supreme national tribunal; and indeed it is self-evident that a decentralized judiciary can hardly be expected to restrain a centralized administration. Nor is the protection afforded to the bench satisfactory. The constitution provides that judges, except in the lowest courts, shall be irremovable after three years of service, ${ }^{1}$ and by statute they can be retired only on account of illness, and removed only for crime or neglect of duty, and in these cases only with the approval of the Court of Cassation at Rome. But a judge is not protected against a transfer from one judicial post to another of the same rank, and although by royal decree a commission annually appointed by the court at Rome must be consulted before such a transfer can be made, its advice is not binding on the government. ${ }^{2}$ The judges are, therefore, by no means entirely independent of the executive, and complaints are often made that they are altogether too much under its

1 Statuto, Art. 69.

2 Brusa, pp. $277^{-278}$. In 1878 this decree was repealed for a time, and one hundred and twenty-two transfers were made in six months. Minghetti, pp. I34-135. 
control. It is impossible to say how far these complaints are justified, ${ }^{1}$ but it is certain that the judiciary either has not enough power, or does not feel sufficiently free, to protect individuals against an oppressive abuse of political power, especially in local matters. This is true even in tranquil times, while the wholesale resort to martial law by the proclamation of the state of siege during the troubles in Sicily and at Carrara some years ago shows that the courts find it hard to cope with disorder on any large scale. $^{2}$

The judicial system has been dwelt upon here at what may seem an inordinate length because its condition is one of the most important factors in the present political condition of the kingdom.

\section{The Church}

There is one institution in Italy which is not strictly a part of the government, but is so closely connected with it, and has so direct an influence on politics, that it cannot be passed over. This is the Catholic Church. Within the last quarter of a century every country in central Europe has found itself confronted with the Catholic question, and has been obliged to grapple with it; but the matter has a

${ }^{1}$ Writing in 1878 , Jacini (I Conservalori, p. 29) said that, so far, the judiciary had resisted all party pressure, but since that time this does not seem to have been true. See Minghetti, ubi supra; Turiello, Falti, p. 316; Proposte, pp. 234-235; De Viti di Marco, "The Political Situation in Italy," Nineteenth Cent., Oct., 1895; Pareto, "L'Italie Economique," Revule des Deux Mondes, Oct. 15, 1891, Giornale dei Economisti, March, 1895, p. 353; Ruiz, Ann. Amer. Acad. of Pol. Sci., Sept., 1895, p. 54; Wolffson, "Italian Secret Societies," Contemp. Rev., May, I8gI; Lord, "Italia non Fara da Se," Nineteenth Cent., March, I892. The charge that the courts were subject to political influence was made by the Parliamentary committee on the bank scandals in December, 1894 .

${ }^{2}$ Contrast with these events the Chicago riots of 1894 , where not only the military authorities never superseded the judicial, but where the national troops were called into action solely by means of the United States courts. 
peculiar importance in Italy. Not because the Italian is fanatical. On the contrary, his intense religious fervor seems to have burned itself out during the Middle Ages, and has left him comparatively indifferent; yet he clings to the church with a tenacity that is out of proportion to his zeal.' This is due partly to the fact that he knows no other creed, partly to his conservative nature, and partly, perhaps, to the fact that the ceremonies and rites of the Catholic faith, having been moulded for the most part by his own race, are closely fitted to his temperament, and therefore continue to attract him strongly, especially on the æsthetic side. The nation is almost wholly Catholic; and to-day, as in the past, the church in Italy is assailed, not by heretics, but by her own children.

\section{Church and State}

Cavour proclaimed the doctrine of a free church in a free state; but although the church is more independent of the government than might have been expected, it was impossible to carry the principle out fully in a country where there is only one religious body, and where that body has always been intimately connected with public life. The church is not independent of the state in Italy in the same sense that it is in America; and this fact has led some of the Italian advocates of the doctrine to give it an entirely different meaning from that which it has here. They complain, for example, that the actual relation between church and state is based on the idea that the church is a private association instead of a public institution, and lament that the state has surrendered too much its control over the educa-

${ }^{1}$ Sir Charles Dilke, in his Present Position of European Politics (pp. 26I262), quotes the saying that the Italians would be a nation of freethinkers if they had ever been known to think, and remarks that although the epigram is unfair, there is a certain measure of truth underlying it. 
tion of priests ${ }^{1}$ - expressions which amount to a complaint that the church is too free. But, although the principle is not applied rigorously in Italy, it has been carried out to a considerable extent. The state has abandoned the right of nomination to ecclesiastical offices, which had existed in some of the former Italian principalities; and the bishops are no longer required to take an oath of allegiance to the king. ${ }^{2}$ Moreover, the so-called exequatur and placet, that is, the requirement of permits from the government for the publication and execution of the acts of ecclesiastical authorities, have been given up. ${ }^{3}$ The state has also renounced all control over the seminaries for priests in Rome, ${ }^{4}$ and rarely interferes with those elsewhere; ${ }^{5}$ and finally the church has been granted freedom of meeting, of publication, and of jurisdiction in spiritual matters. ${ }^{6}$ Conversely, the acts of the ecclesiastical authorities have ceased to be privileged. They have no legal force if they are contrary to law or violate private rights, and they are not exempt from the provisions of the criminal code. ${ }^{7}$

1 See, for example, Brusa, pp. 426-427, 429 .

2 Act of May r3, r87r, Tit. ii, Art. I5. It has been decided that in the case of the lower clergy the oath was not dispensed with wherever it had been required by earlier laws (Brusa, p. 428); and even the bishops are not entirely independent of the state, for the royal exequatur is still required for the enjoyment of their revenues (Id., p. 437). At times these have actually been withheld, notably in 1877 . Speyer, in Unsere Zeit, I878, ii. 604.

${ }^{3}$ Act of May ${ }_{3} 3,187$, Tit. ii. Art. 16.

'Id., Tit. i. Art. 13.

- Brusa, p. 438.

- Id., Tit. ii. Arts. 14, 16, 17. Religious processions outside the churches may be forbidden by the local authorities, if they are liable to interifere with public order or public health. Law of June 30 , I889, Art. 8.

${ }^{7}$ Act of May 13, r87r, Tit. ii, Art. I7. The Penal Code of I 888 specially punishes abuse of language by the clergy. Brusa, p. 61 . 


\section{The Monastic Orders}

A thorny question for the new kingdom was involved in the position of the monastic orders, many of which still held great tracts of land, but had long outlived their usefulness and were felt to be an anachronism. The solution adopted, though almost a necessity, was drastic, and illustrates how far the theory of a free church in a free state was at this time from being a reality. The order of Jesuits was absolutely excluded from the kingdom; ${ }^{1}$ and even in the case of the other bodies, which had not aroused such violent antipathy, the government determined, while sparing the existing members, to forbid the enrollment of new recruits. By the statutes of 1866 and 1867 , therefore, all these monastic institutions and most of the benefices without a cure of souls were suppressed, and their property transferred to the state to be employed for the support of religion; but a pension for life was reserved to the present possessors, who were also allowed to remain in their establishments. ${ }^{2}$ Every traveler will remember the aged monks in white habits who might be seen wandering among the cloisters of the Val d'Ema, near Florence. These are the last representatives of a mighty order that once overspread Christendom; and with the spirit of romance which Italy cannot shake off even if she would, they have been allowed to drop away one by one until the monastery becomes silent forever.

The convents were not the only great landowners in the church. Many of the higher secular clergy were also richly endowed. But there was a strong feeling that the soil of the

1 Brusa, p. 56 , note 4 .

2 Acts of July 7, 1866, and Aug. 15, 1867. See, also, Brusa, pp. 431-433. By an Act of 1873 these provisions were applied to Rome, but in a modified form. Brusa, $I b$. 
country ought to be controlled by laymen, and that the larger ecclesiastical incomes ought to be reduced. This feeling found its expression in the same statutes of 1866 and r867, by which all church lands, except those belonging to parishes, those used by bishops and other dignitaries, and buildings actually devoted to worship, were taken by the state and converted into perpetual five per cent annuities; ${ }^{1}$ while all ecclesiastical revenues, not of a parochial nature, were taxed thirty per cent, or in other words partially confiscated. ${ }^{2}$

\section{The Pope}

By far the most difficult question was presented by the papacy. The Holy See had ruled over a territory of considerable size extending across the peninsula from the Mediterranean to the Adriatic. It claimed to trace its rights from a grant made in the fourth century by the Emperor Constantine the Great to Pope Sylvester, and in fact its dominion was as old and well founded as that of any monarch in Europe. It felt that the sovereignty over its own states - the so-called temporal power - was necessary for its independence, and that if the Pope lived in a city subject to another ruler he could not remain entirely free in spiritual matters. But the Italians felt no less strongly that their country would never be a complete nation until it included everything between the Alps and

1 Act of July 7, I866, Arts. I I-I8.

2 Act of Aug. 15, I867, Art. 18. By the Act of July 7, I866, Art. 3 I, the revenues of bishops exceeding 10,000 lire are taxed progressively for the benefit of the general fund for religion, the whole excess above $60, \infty 00$ lire being so taken. But if, on the other hand, the income of a bishop falls below 6,000 lire, it is made up to that sum out of the general fund (Art. 19). Similar taxes for the benefit of the fund are imposed on other ecclesiastical revenues. In the Act of 1873 , Rome was more gently treated. Brusa, pp. $432-433$. 
the sea, with Rome as its capital, and this feeling was fully shared by the Romans themselves.

The northern and eastern part of the Papal States was annexed to the new kingdom of Italy at the same time as Naples and Sicily, that is in I860; but Rome and the country about it was protected by Napoleon III, whose power depended so much on the support of his ultramontane subjects that he could not safely desert the cause of the Pope. Italy chafed under his interference, and waited uneasily until the war with Prussia forced him to recall his troops. Then came the revolution that overturned his throne. An Italian army at once crossed the frontier of the Papal States, and entered Rome on September 20, I870.

\section{The Law of the Papal Guarantees}

The problem before the government was a delicate one, because any appearance of an intention to treat the Pope as an Italian subject would have excited the indignation of the whole Catholic world, and might have led to foreign complications, or even to an armed intervention in favor of the temporal power. The cabinet determined, therefore, that a law fixing definitely the position and privileges of the Holy See should be passed before the seat of government was moved to Rome. Recognizing the peculiar relations of the Pope to other states, the ministers proposed to make this law one of international bearing, so that it would have an effect analogous to that of a treaty, but they yielded to the firm opposition of the Left in the Chamber, and the act was finally passed as a piece of domestic legislation. ${ }^{1}$ This is the celebrated Law of the Papal Guarantees, which was enacted in May, $187 \mathrm{I}$, and remains unchanged at the present day. Its object is to insure the free-

1 Petriccelli della Gattina, Storia d' Italia, pp. 93-94. 
dom of the Pope in the exercise of all his spiritual functions, and for that purpose it surrounds him with most of the privileges of sovereignty. His person is declared sacred and inviolable; assaults or public slander directed against him being punishable like similar offenses against the king. Public officials in the exercise of their duties are forbidden to enter his palace or its grounds; and the same exemption applies to the place of meeting of a Conclave or Ecumenic Council. Searching any papal offices that have solely spiritual functions, or confiscating papers therefrom, is prohibited, and it is provided that priests shall not be punished or questioned for publishing, in the course of their duties, the acts of the spiritual authority of the Holy See. The Pope is accorded the honors of a sovereign prince, and persons accredited to him enjoy all the immunities of diplomatic agents. He is guaranteed free intercourse with the bishops, and indeed with the whole Catholic world, messages sent in his name being placed on the same footing as those of foreign governments. Moreover he is granted a perpetual annuity of over six hundred thousand dollars, which is entered in the great book of state debts, and is free from all tax. This grant he has always refused to accept, and every year it is returned to the treasury. Finally he is left in absolute possession of the palaces of the Vatican, the Lateran, and Castel Gandolfo, with all their buildings, gardens, and lands, free of taxes. ${ }^{1}$

It will be observed that this law - which is alleged, by the way, to have been faithfully carried out by the Italian government - assures to the Pope absolute freedom in the exercise

1 This is the law of May I3, I871, several sections of which have already been cited. There is a criticism of the legal situation of the Holy See from a papal standpoint by Comte Rostworowski, entitled "La Situation Internationale du Saint-Siège," in the Ann. de l'Ecole Libre des Sciences Poliliques, 1892 , p. 102. 
of his functions as head of the Catholic Church, and guards him against all personal disrespect. Nevertheless, neither Pius IX nor his successors have accepted it; and indeed they could not have done so without acknowledging the authority of the government by which it was enacted, and this they have never been willing to do. They have not ceased for a moment to protest against the destruction of the temporal power; in fact, they have avoided everything that could possibly be construed as a recognition of the Kingdom of Italy. The Pope has affected to consider himself a prisoner, and never since the royal cannon opened a breach in the Roman walls at the Porta Pia has he placed his foot outside the grounds of the Vatican. ${ }^{1}$ He even refused to allow the clerical party to vote for deputies to Parliament, on the ground that this would involve a tacit acknowledgment of the legality of the existing government; and thus a large portion of the Italian people took no part in national politics, although the same men voted freely and sometimes won victories at municipal elections. ${ }^{2}$ Such a condition of things was very unfortunate, for it tended to create a hostility between religion and patriotism, and made it very hard for a man to be faithful both to his church and his country. If the Italians had any liking for other sects, these would no doubt increase rapidly; but as religion and Catholicism are synonymous terms in Italy, the antagonism between church and state merely stimulates skepticism and indifference.

\section{Difficulty of the Question}

It is not easy to see how the papal question will finally be solved. Pope Leo XIII was a man of great tact, and with marvelous dexterity he changed the policy of the

1 Until 1888 he did not even appear in St. Peter's.

2 In 1905 an encyclical of Pius $\mathrm{X}$ somewhat relaxed the prohibition. 
Vatican so as to bring it into harmony with the nineteenth century. He made a peace with Bismarck by which the Iron Chancellor virtually acknowledged defeat; and by his conciliatory tone towards the French Republic he made fair headway in checking the Radicals in France with their hatred of the church. Yet even Leo XIII was unable to come to terms with Italy. One thing is clear. Italy will never give up Rome, nor is there the slightest probablility that any foreign country will try to force her to do so; and, indeed, it is said that even in the Vatican the restoration of the temporal power is considered hopeless. ${ }^{1}$ To the outside observer it hardly appears desirable in the interest of the papacy itself, because with the loss of its secular functions, the Holy See has gained enormously in ecclesiastical authority. This is not an accident, for the destruction of the temporal power is one step in the long movement for the separation of church and state, which during the last hundred years has been breaking the local and national ties of the clergy in the different countries, and has thus made the Catholic Church more cosmopolitan, more centralized, and more dependent on its spiritual head. Such, however, is not the view of many ardent Catholics, who are so dissatisfied with the present situation that a departure of the Pope from Rome has often been suggested; but although

1 In an answer ("Italy, France, and the Papacy," Contemp. Rev., Aug., I89I) to an article entitled "The Savoy Dynasty, the Pope, and the Republic," by an anonymous writer (Contemp. Rev., Apr., I 891), Crispi spoke of the possibility of a French intervention in favor of the temporal power as a real danger. One cannot help feeling that this must have been said rather for its effect than from conviction. In a previous answer to the same article ("Italy and France," Contemp. Rev., June, I891), Crispi made the interesting statement that even in Rome only the highest cluurch dignitaries want the temporal power, while over the rest of Italy the clergy never were papal, and are not so now. In a later number of the same Review the Triple Alliance and the papal question are further discussed by Emile de Laveleye ("The Foreign Policy of Italy," Contemp. Rev., Feb., 1892.) 
on more than one occasion a removal has been said to be imminent, it has always been in the highest degree unlikely, for the Holy See could not get from any other state in whose territory it might settle terms more favorable than those accorded by the Law of the Papal Guarantees; and even if it should accept a grant of complete sovereignty over some island or small tract of land, the loss in prestige from the change of residence would be incalculable. The veneration of the past still clings to Rome, and although the civic splendor of the Vatican is gone, the Pope bereft of his temporal power wields a greater spiritual influence than he has had for centuries. 


\section{CHAPTER IX}

\section{GERMANY: STRUCTURE OF THE EMPIRE \\ Former Subdivision of Germany}

Cherbuliez has remarked that most countries which have grown in size have started with a compact territory and increased it by absorbing the adjacent lands, but that Prussia began with her frontiers and afterwards filled in between them. The statement is almost literally true, for early in the seventeenth century the electors of Brandenburg, who were the ancestors of the kings of Prussia, acquired the large Duchy of Prussia on the Baltic and the Duchy of Cleves on the Rhine, possessions which form to-day very nearly the extreme limits of the Prussian monarchy on the east and west. At that time these duchies did not touch the electors' other territories, and in fact until half a century ago several states were so wedged in among the Prussian dominions as to cut the kingdom quite in two. Nor was this the case with Prussia alone. The whole map of Germany as it stood in the last century was a mass of patches of different color mingled together in bewildering confusion. Not only were some of the principalities inconceivably small, but they often consisted in part of outlying districts at a distance from one another, and entirely surrounded by the estates of some other potentate. The cause of such a state of things is to be found in the excessive development of the feudal system, which treated sovereignty as a private right of the ruler, so that princes dealt with their fiefs very much as men do with their lands to-day. They acquired them freely in all direc- 
tions by inheritance, by marriage, and even by purchase, and, what was worse, at their death they divided them as they pleased among their sons. Still another source of confusion was presented by the bishops and other high church dignitaries, who held large estates which they ruled as temporal sovereigns. The result was that Germany was divided in a most fantastic way among several hundred princes, who owed, it is true, a shadowy allegiance to the Emperor as head of the Holy Roman Empire, but for all practical purposes were virtually independent.

\section{The Growth of Prussia}

Almost alone among the German states Prussia was steadily gaining in size and power. Her growth may be traced primarily to the Constitutio Achillea of I473, which forbade the splitting up of the monarchy among the sons of the electors, and thus kept all their dominions together; but it was due chiefly to the thrift, the energy, and the sagacity of the rulers of the House of Hohenzollern. At the close of the thirty years' war, in 1648 , the Great Elector obtained possessions which made his domains larger than those of any other German state except Austria, and in the next century the annexations of Frederic the Great more than doubled the population of his kingdom. The growth of Prussia was suddenly checked by an event that tended ultimately to hasten its development. This was the outbreak of the French Revolution and the career of Bonaparte. When a series of victories had laid Germany at his feet, Napoleon suppressed a large number of petty principalities, including all the ecclesiastical ones, and combined the smaller states that remained into the Confederation of the Rhine. He also deprived Prussia of half her territory, thinking by these means to reduce her to impotence, and create 
in the heart of Germany a body that would always be devoted to the cause of France. But in fact the petty principalities had been too small to act separately or to combine effectively, and too independent to be made serviceable by any sovereign; and by suppressing them Napoleon had given the Germans a capacity for organization which was used against him as soon as the tide turned. ${ }^{1}$

\section{The Germanic Confederation}

After his overthrow Germany was reorganized by the treaty of Vienna, and the states, which now numbered only thirty-nine, were formed into. a loose confederation. This was not properly a federal union, but rather a perpetual international alliance, the states remaining separate and independent, except for matters affecting the external and internal safety of Germany. The only organ of the Confederation was a diet composed of the diplomatic agents of the different states, who acted like ambassadors, and voted in accordance with the instructions they received from their respective governments. It had power to declare war and make peace, to organize the federal army, to enact laws for the purpose of applying the constitution, and to decide disputes between the states; but it had no administrative officers under its command, the federal laws being executed entirely by the officials of the states. Hence the only means of getting its orders carried out in case a state refused to obey them was by the process known as federal execution, which meant that the diet called on one or more members

1 This is very well stated by Colonel Malleson in his Refounding of the German Empire, pp. 4-6. Napoleon prophesied that within fifty years all Europe would be either Republican or Cossack. One of the chief causes of the failure of this prediction has been the creation of a united Germany, which Napoleon himself unwittingly helped to bring about. 
of the Confederation to attack the recalcitrant state, and by invading its territories to compel submission.

The procedure in the diet was complicated. For ordinary matters it acted by sections called curice, when the eleven largest states had one vote apiece, the other twenty-eight being combined into six groups each of which had a single vote. For constitutional questions, on the other hand, and those relating to peace and war, the diet proceeded in plenum, and in that case each of the smaller states had one vote, while the fourteen largest had two, three, or four votes apiece. ${ }^{1}$ This distribution of votes was by no means in proportion to population, for the largest states were much more than four times as large as the smallest, but it was a distinct recognition of an inequality of rights on the part of the states, and as such it still retains an especial importance because the arrangement of the votes in the plenum has continued almost unchanged in one of the chief organs of the Empire to-day. It must not be supposed, however, that the influence of the states in the diet was determined by the number of their votes, for Austria, which had a permanent right to the presidency of the assembly, and Prussia, which had a permanent right to the vice-presidency, exercised in fact a controlling authority. When these two great powers agreed that they had their own way; when they disagreed, which often happened, the opinion of Austria usually prevailed.

\section{The Attempt at Union in $1848-49$}

The wars of Napoleon did a great deal more for Germany than to suppress petty principalities and give rise to a clumsy confederation. They awakened a sentiment of German nationality. At first this was only a sentiment, and for

${ }^{1}$ Six of the states had four votes, five had three, three had two, and twenty-five had one. 
a long period it had no practical results. It was especially strong among the Liberals, and grew stronger as time went on; but during the reaction that followed the overthrow of Napoleon, the Libcrals had little influence, until the convulsions of $r 848$ and $r 849$ brought them to the front. At this time they tried hard to bring about a national union of Germany, but they were sadly hampered by their theoretical views and their want of political experience. Their aim was a German state constructed on an ideal model, and they lacked the quality which is essential to real statesmanship the power to distinguish the elements in the existing order of things which have a solid basis, to seize upon these, and adapt them to the end in view. Hence their efforts expended themselves in declamation and academic discussion, and came to nothing. In May, 1848 , they succeeded in bringing together at Frankfort a National German Parliament elected by universal suffrage, and if this body had proposed quickly any rational plan for a union of Germany, the chances of its adoption would have been very good; for every government in the country had been forced to give way before the fierce onslaught of the Liberal movement. But unfortunately more than four months of precious time were consumed in debating the primary rights of the citizen, and when these were finally disposed of the tide was beginning to ebb. At last, in March, I849, a constitution was agreed upon, and the imperial crown was tendered to the King of Prussia; but the offer came too late. Had it been made in the preceding summer it might have been accepted, but now the revolution had spent its force. Austria, at first paralyzed by insurrection, had now recovered from the shock, was rapidly putting down her rebellious subjects, and under the able leadership of Prince Schwartzenberg was determined to prevent any reorganization of Germany that 
would diminish her influence. After a feeble struggle Prussia yielded to her more determined rival, the revolutionary movement came to an end, and the old Confederation was restored.

\section{Bismarck}

Again a period of reaction set in, which lasted about ten years, when Gemany was thrilled by the events in Italy, and the Liberals again became powerful. Whether they would have avoided their former mistakes and succeeded better it is impossible to say, for just at this time there appeared upon the scene a man who was destined to stamp his will on Germany, and change the whole face of European politics. That man was von Bismarck. He belonged to the lesser Prussian nobility, which is the most conservative class in the race; but he was of far too large a calibre to be bound down by traditional prejudices; and indeed he had already formed very decided opinions of his own on the subject of German unity. He had served as a representative of Prussia at the diet, and had learned that a German nation was impossible so long as the two great powers - Austria and Prussia - were contending for a mastery. He saw that the first step must be the forcible expulsion of Austria from all share in German politics; and he believed that union could never be brought about by argument, that the Germans could not be persuaded, but must be compelled to unite, that the work must be done, as he expressed it, by blood and iron.

\section{The Constitutional Conflict}

An important advance towards closer relations between the States had, indeed, been made long ago by the creation of the Zollverein or customs union. This had been founded by Prussia in the early part of the century, and had grad- 
ually been extended until it included almost all the German states except Austria, which had been jealously excluded by the Prussian statesmen; but valuable as the Zollverein was in teaching the people their common interests, Bismarck was convinced that no further progress could be expected without the use of force. Now it was precisely on this point that his methods differed from those of the Liberals, because war formed no part of their programme, and for that reason they were unable to understand his policy. In 1859 they had obtained a majority in the lower house of the Prussian Parliament, and had very soon become involved in a quarrel with King William over the reorganization of the army on which he had set his heart. ${ }^{1}$ In 1862 the King turned to Bismarck and made him the President of the Council. Bismarck submitted to the chamber a budget containing the appropriations for the military changes, and when the chamber refused to pass it he withdrew it, and governed without any budget at all. This he was enabled to do, because the taxes were collected under standing laws which required no reënactment, and in fact could not be changed without the consent of the crown; and because a doctrine was developed that in case the king and the two houses were unable to agree upon appropriations, the king was entitled to make all those expenditures which were necessary in order to carry on the government in accordance with the laws regulating the various branches of the administration. The Liberals were furious at this budgetless rule, but Bismarck proceeded in spite of them. He persuaded Austria to join Prussia in wresting the duchies of Schleswig and Holstein from Denmark in 1864 , and then contrived to quarrel with her about the disposition to be made of them. The majority in the

1 William became Regent on Oct. 7,1858 , and on the death of his brother Frederick William IV, on January 2, I86r, he became King. 
German diet sided with Austria, and ordered the troops of the Confederation mobilized against Prussia. Then followed the war of I866, and the crushing defeat of Austria and the smaller German states that took her part.

\section{The North German Confederation}

Bismarck had originally intended to compel all the states except Austria to form a federal union, but the intervention of Napoleon III forced him to abandon the plan and limit the Confederation to the country north of the river Main. ${ }^{1}$ He therefore determined as a compensation to increase the direct strength of Prussia by annexing the states that had fought against her. ${ }^{2}$ Hanover, Electoral Hesse-Nassau, ${ }^{3}$ and Frankfort, besides Schleswig-Holstein, were accordingly incorporated in Prussia, while with the other states north of the Main a new federal union was formed under the name of the North German Confederation. ${ }^{4}$ This had for its president the Prussian king; and for its legislature two chambers - one the Reichstag, a popular assembly elected by universal suffrage, and the other the Bundesrath, or federal council, which was copied from the old diet, and composed in the same way of the plenipotentiaries of the different states, but was endowed with peculiar and extensive powers. Austria was excluded from all participation in German

${ }^{1}$ Luxemburg and Limburg, which belonged to Holland, had been a part of the old Confederation, but were allowed to drop out at this time, and were not included in the reorganization of Germany. This was true also of the tiny principality of Lichtenstein in the south.

2 Von Sybel, Begrïndung des Deutschen Reiches, book xix, ch. ii.

${ }^{3}$ Also called Hesse-Cassel to distinguish it from Hesse-Darmstadt or grand-ducal Hesse, which, being the only Hesse remaining in existence as a separate state, is hereinafter called simply Hesse.

4 The constitution of the Confederation was first agreed upon by the governments of the several states, then accepted with slight modifications by a National Assembly elected by universal suffrage for the purpose, and finally ratified by the legislatures of the states. 
politics; while the four States south of the Main - Bavaria, Wurtemberg, Baden, and Hesse ${ }^{1}$ - became independent, and were expressly left at liberty to form a separate union among themselves. As a matter of fact, they made offensive and defensive alliances with the Confederation, and formed with it a Zollverein or customs union, whose organs were the two chambers of the Confederation reinforced by representatives from the southern states. Every one felt that the union of Germany was incomplete so long as these states were not a part of it; but Bavaria and Wurtemberg were reluctant to surrender their independence; and the enthusiasm aroused by the war with France in I 870 was required to raise the sentiment for German nationality to such a pitch as to sweep them into line. Even then they demanded and obtained special privileges as the price of their adhesion; but at last all the difficulties were arranged, and in the autumn of 1870 treaties were made with the four southern states whereby they joined the union. The name of the Confederation was changed at the same time to that of "German Empire," the president being given the title of Kaiser; and in the course of the following winter the changes and additions entailed by these treaties were embodied in a new draft of the constitution. ${ }^{2}$

1 This is Hesse-Darmstadt. It lay on both sides of the Main, but the part on the north of that river was already included in the North German Confederation.

2 Cf. Laband, Deutsches Staatsrecht, 2d ed., ch, i. In I873 three amendments were made in this instrument. The first (that of Feb. 25) abolished the provision limiting the right to vote in the Reichstag, on those matters which by the constitution are not common to the whole Empire, to the representatives of the states affected. The second (that of March 3) put the lighthouses, buoys, etc., along the coast under the control of the federal government; and the third (that of Dec. 20) extended the legislative power of the Empire over the whole field of civil and criminal law. It had previously covered contracts, commercial law, and criminal law. In I 885 (Art. 24), an amendment was adopted changing the term of the Reichstag from three 


\section{The Constitution of the Empire}

This instrument has nothing about it that is abstract or ideal. It was drawn up by a man of affairs who knew precisely what he wanted, and understood very well the limitations imposed upon him, and the concessions he was obliged to make to the existing order of things. His prime object was to create a powerful military state; and hence, as has been pointed out, the articles on most subjects are comparatively meagre, but those on the army, the navy, and the revenue are drawn up with a minuteness befitting the by-laws of a commercial company. ${ }^{1}$

to five years. In 1893 (Art. $53, \S 5$ ), an amendment was adopted about the method of conscription for the navy. In 1904 (Art. 70), the article on the finances was amended to authorize levying contributions on the states, in addition to federal taxes. In I905 (Art. 59, $\$ \mathrm{I}$ ), the article on compulsory military service was changed, chiefly to substitute two for three years of active service. In May, r9o6 (Art. 32), an amendment was made permitting the payment of members of the Reichstag; and in June of the same year (Art. $38, \S 2$ ), an amendment was made about the allowance to the states for the cost of collecting the excise on beer. In May, IgI I (Art. 6a), an article was added virtually making Alsace-Lorraine a member of the Confederation; and in December, I9 I (Art. 54), a change was made about the tolls chargeable for improvements in navigation. As this goes to print, an amendment is proposed that a declaration of war shall require the consent of the Reichstag.

Substantial changes in the fundamental law of the Empire have been made without a formal modification of the text. (See Laband, i. 48-49, 51.) Some of the German jurists maintain that such a practice is wrong (von Rönne, Staatsrecht des Deulschen Reiches, 2d ed., pp. 31-34; Meyer, Lehrbuch des Deutschen Staalsrechts, P. 4I6); others that it is quite proper, provided the majority required in the Bundesrath for a formal amendment of the constitution is in fact obtained. (Laband, i. 545-549; Arndt, Verfassung des Deulschen Reiches, pp. 290-291.)

1 Lebon, Eludes sur l'Allemagne Politique, Introd., p. iii.

Amendments to the constitution can be made by a majority vote in the Reichstag, but are vetoed by fourteen adverse votes in the Bundesrath. 


\section{Nature of the Confederation}

Before proceeding to a description of the organs of the state, it will be worth while to examine the nature of the Confederation. We are in the habit of speaking of the German Empire as a federal government, and rightly; but we must bear in mind that it departs essentially from the type which we commonly associate with that term, and which is embodied in our own constitution. We conceive of a federal system as one in which there is a division of powers between the central government and the states according to subjects, so that in those matters which fall within the sphere of federal control the central government not only makes the laws, but executes them by means of its own officials. Thus Congress enacts a tariff; the United States custom house collects the duties; and the federal courts decide the questions that arise under the law. But all this is very different in Germany. There the legislative power of the central government is far more extensive than in this country, for it includes almost everything that is placed under the control of Congress and many other matters besides. In addition to such subjects as customs duties and taxes, the army and navy, the consular service, and the protection of foreign commerce, which are obviously essential, the list comprises many matters of domestic legislation. It covers not only the posts and telegraphs, ${ }^{1}$ transportation on streams running through more than one state, and extraditions between the states, but also in general terms railroads, ${ }^{2}$ roads and canals, citizenship, travel, change of residence, the carrying on of trades, also the regulation of weights and measures, of coinage and paper money, of banking, patents, copyrights, and of medical and veterinary police. Moreover, it

1 Except in Bavaria and Wurtemberg.

2 Except in Bavaria. 
includes the regulation of the press and associations, and finally the whole domain of ordinary civil and criminal law and of judicial proceedings. All these things are declared subject to imperial legislation and supervision. ${ }^{1}$

The administrative power of the Empire, on the other hand, is very small, the federal laws being carried out in the main by the officers of the states as under the Confederation of 18 I $_{5}$. Except, indeed, for foreign affairs, the navy, and to some extent the army, and the postal and telegraphic service, the executive functions of the Empire are limited for the most part to the laying down of general regulations, and a supervision of their execution by the several states. ${ }^{2}$ Thus the federal government can enact a tariff, make regulations which shall govern the customhouse officers, and appoint inspectors to see that they are carried out; but the duties are actually collected by state officials. ${ }^{3}$ One naturally asks what happens if a state refuses or fails to carry out a federal law. The matter is reported to the Bundesrath, which decides any controversy about the interpretation of the law. ${ }^{4}$ But suppose the state persists in its refusal to administer the law, what can the federal government do ? It cannot give effect to the law itself, nor has it any officials for

1 Art. 4 of the constitution and the amendment of Dec. $20,1873$.

2 See Laband, $\S 66$. In the case of the army (Const. Arts. 63-66) and the posts and telegraphs (Art. 50), the highest officers are appointed by the Kaiser, who gives them their orders, while the subordinates are appointed by the states.

${ }^{3}$ As a rule the whole net revenue flows into the imperial treasury. In case the receipts of the Empire are not equal to its expenses, the deficiency is covered by means of contributions called Matricularbeiträge assessed on the different states in proportion to their population. (Const. Art. 70, and see Laband, 6th ed., § 45.) This was originally intended to be a subsidiary and exceptional source of revenue, but owing to the quarrel between Bismarck and the Reichstag on the subject of federal taxation, the Matricularbeiträge became large for many years. (Cf. Lebon, Allemagne, p. 1o6 el seq.)

- Const. Art. 7, 83 . 
the purpose. Its only resource is federal execution - that is, an armed attack on the delinquent state - which can be ordered by the Bundesrath, and carried out by the Kaiser. ${ }^{1}$ This last resort has never been used, nor is it likely to be, because the Kaiser is also the King of Prussia, and Prussia alone is not only larger than any other state, but larger than all the rest put together. Execution against Prussia is therefore doubly out of the question; and any other state would be so easily overpowered that it is certain to submit, rather than provoke an appeal to force.

\section{The Privileges of Prussia}

Another conception that we associate with federal government is an equality of rights among the members. But in the German Empire all is inequality. It would, indeed, have been impossible to make a federation on really equal terms between a number of states, one of which contained three fifths of the total population, while the other twenty-four contained altogether only two fifths. The compact could not fail to resemble that between the lion and the fox, or rather a compact between a lion, half a dozen foxes, and a score of mice. The larger states are accorded all sorts of privileges, and so much of the lion's share of these falls to Prussia that it is hardly too much to say that she rules Germany with the advice and assistance of the other states. In the first place she has a perpetual right to have her king the Kaiser. ${ }^{2}$ Secondly, amendments to the constitution - although requiring only an ordinary majority vote in the Reichstag - are defeated in the Bundesrath if fourteen negative votes are thrown against them, and as Prussia has seventeen votes in that body, she has an absolute veto on all

1 Const. Art. I9, and see Laband, i. 105-106.

${ }^{2}$ Const. Art. II. 
changes of the constitution. ${ }^{1}$ Besides this, it is expressly provided that in the case of all bills relating to the army, the navy, the customs duties, or the excises, and in the case of all proposals to revise the administrative regulations for collecting the revenue, the vote of Prussia in the Bundesrath is decisive if cast in favor of maintaining the existing institutions. ${ }^{2}$ In other words, Prussia has a veto on all measures for making changes in the army, the navy, or the taxes. She has also the casting vote in case of a tie in the Bundesrath, ${ }^{3}$ and the chairmanship of all the standing committees of that body. ${ }^{4}$

These are Prussia's constitutional privileges; but she has others obtained by private agreement with her smaller partners; for the several states are at liberty to make conventions or treaties with each other in regard to the affairs that remain subject to their control. ${ }^{5}$ When the North German Confederation was formed, universal military service and a uniform organization like that of Prussia were introduced into all the states, but the army was not made exclusively a national nor left entirely a state institution. ${ }^{6}$ The

1 Const. Art. 78. In the North German Confederation a two thirds vote in the Bundesrath was necessary for a change in the constitution, but when the South German states were admitted, Prussia had no longer a third of the delegates, and in order to preserve her veto the proportion required was increased to three quarters. Finally at the instance of Bavaria, which wanted to enlarge the power of the states of the second size, it was agreed that fourteen negative votes should be enough to defeat an amendment to the constitution. Arndt, p. 290; Robinson, The German Bundesrath, p. 40.

${ }^{2}$ Const. Arts. 5, 35, and 37.

${ }^{3}$ Const. Art. 7.

${ }^{4}$ Const. Art. 8; Laband, i. 264. Except the committee on foreign affairs, where, as will be explained hereafter, it would be of no use to her.

${ }^{5}$ Laband, $\$ 63$. To some extent the states are at liberty to make separate conventions with foreign powers, and they have a right to send their own representatives to foreign courts. Laband, $\S 7 \mathrm{I}$.

6 Const. Arts. 57-68. The last eight of these articles do not apply to Bavaria, and only partially to Wurtemberg. The expense of maintaining 
constitution provides that the military laws shall be made by the Empire, ${ }^{1}$ and declares that the forces of the country shall be a single army under the command of the Kaiser, whose orders they are bound to obey. It gives him a right to inspect and dispose of the troops, and to appoint all officers whose command includes the entire contingent of a state. It provides also that the selection of the generals shall be subject to his approval, but it leaves to the states the appointment of all inferior officers, and the management of their troops in other respects. Now these reserved rights were of little value, and all but three of the states transferred them to Prussia, chiefly in consideration of an agreement on the part of the Kaiser not to remove the troops from their own territory except in case of actual necessity. Thus the contingents of these states are recruited, drilled, and commanded by Prussia, and form, in short, an integral part of her army. ${ }^{2}$

A number of conventions of a similar character affecting other public matters, such as the postal service and the jurisdiction of the courts, have been concluded between the

the army is borne by the Empire. Unlike the army, the navy is a purely national institution. Art. 53 .

1 The double position of the Prussian monarch comes out curiously here, for the constitution provides: first, that the military laws and regulations of Prussia shall be in force throughout the Empire, until a comprehensive imperial military law shall be enacted; and second that any future general orders of the Prussian army shall be communicated by the military committee of the Bundesrath to the commanders of the other contingents for appropriate imitation.

2 Some of the states transferred all their rights (Baden with a provision that her troops should form a separate corps); others retained certain rights, mainly of an honorary nature, but agreed that their troops should be united with the Prussian army, and that Prussia should appoint the officers. Only Bavaria, Saxony, and Wurtemberg still exercise the military functions reserved to them by the constitution. Cf. Laband, \$ 94, iii; Schulze, Lehrbuch des Deutschen Staatsrechts, \$335; Meyer, Lehrbuch, \$197. 
states; but the most comprehensive compact of all was made by Waldeck. The ruler of this little principality was crippled with debts, and unable to raise the money required for the reorganization of his army. So he sold his governmental rights as a whole to the King of Prussia, retired from business, and went to Italy to live upon his income; while the Prussian government, having bought the goodwill of his trade, proceeded to carry it on as his successor. There is something decidedly comical in treating the right to govern a community as a marketable commodity, to be bought and sold for cash; but to Bismarck the matter presented itself as a perfectly natural business transaction, and in fact the contract bears a strong resemblance to the lease of a small American railroad to a larger one.

\section{Privilege of Other States}

Such are the special privileges of Prussia. Those reserved to the other states are far less extensive. By the constitution Hamburg and Bremen had a right to remain free ports, outside of the operation of the tariff laws; ${ }^{1}$ but both of them have now surrendered this privilege. ${ }^{2}$ The other special rights are mostly enjoyed by the southern states, and were given to them as an inducement to join the Confederation. Thus Bavaria, Wurtemberg, and Baden were exempted from imperial excises on brandy and beer, and given a right to lay excises of their own on these articles. ${ }^{8}$ Bavaria and Wurtemberg have their own postal and telegraph services,

1 Const. Art. 34 .

2 The treaty for this purpose was made with Hamburg in $188 \mathrm{I}$, and went into effect Oct. 1, r888. That with Bremen was made in 1885 . For an account of these treaties and the way they were brought about, see Blum, Das Deulsche Reich zur Zeil Bismarck's, p. 360 et seq.; Leband, ii. gor-904.

s Const. Art. 35. But in 1887 they gave up their privileges in regard to brandy. See Blum, p. 532; Leband, ii. 920, 923-924. 
which are subject only to general imperial laws. ${ }^{1}$ Except for the principle of universal military service, and the agreement to conform to the general organization of the imperial army, Bavaria has in time of peace the entire charge of her own troops, the Kaiser having only a right to inspect them; while Wurtemberg, although not so much favored as this, has greater military privileges than the remaining states. ${ }^{2}$ Bavaria is further exempt from imperial legislation in regard to railroads, ${ }^{3}$ and to residence and settlement; ${ }^{4}$ and finally, by the constitution or by military convention, Bavaria, Saxony, and Wurtemberg have a right to seats on the committees of the Bundesrath on foreign affairs and on the army and fortresses. ${ }^{5}$ In order to guarantee more effectually these privileges, it is provided that they shall not be changed without the consent of the state entitled to them. ${ }^{6}$

\section{The Empire and the Old Confederation}

From this description of the privileges of the different states it is evident that the German Empire is very far from being a federal union of the kind with which we are familiar.

1 Const. Art. 52.

2 Treaties of Nov. 23, 1870, with Bavaria; and Nov. 25, 1870, with Wurtemberg; incorporated in the constitution by a reference in the Appendix to Part XI.

2 Except in the case of lines that have a strategic importance. Const. Art. 46 .

- Const. Art. 4, § r.

5 Const. Art. 8; Laband, i. 113. By the treaty of Nov. 23, 1870 (Schlussprotokoll, Art. ix), Bavaria has a right to preside over the Bundesrath in the absence of Prussia, but as this never happens, the privilege is merely honorary.

- Const. Art. 78. Meyer (Lehrbuch, p. 421) and Zorn (Staatsrecht des Deutschen Reiches, pp. 88-93) think this provision applies only to the limitations on the competence of the Empire, and not to the privileges given to the several states in the organization of the government, such as the presidential rights of Prussia, the allotment of the votes in the Bundesrath, the seats on 
It is rather a continuation of the old Germanic Confederation, with the centre of gravity shifted from the states to the central government, and the preponderating power placed in the hands of Prussia - the other large states retaining privileges roughly in proportion to their size. ${ }^{1}$

Its chief organ of government is still the old diet, renamed the Bundesrath or Federal Council, to which have been added on one side a Kaiser, who is commander-in-chief of the forces, and represents the Empire in its relation with foreign powers; and, on the other, an elected chamber, called the Reichstag, created for the sake of stimulating national sentiment and enlisting popular support as against the local and dynastic influences which have free play in the Bundesrath. Let us consider each of these organs in detail.

committees, etc. Their opinion, however, is not generally accepted. Laband, i. IIO-II4; Schulze, $\S 249$; v. Rönne, ii. 43-48. It is univcrsally agreed that an affirmative vote in the Bundesrath by the delegate of the state is a sufficient consent by that state to a law affecting its privileges so far as the Empire is concerned; but there is a difference of opinion on the question how far the ruler of the state is bound, or can be bound, by state law to consult his parliament. Laband, i. II4-II7; Schulze, book ii. p. 19; v. Rönne, ii. 36-43; Meyer, p. 422; Zorn, pp. 94-98.

1 In saying this I am speaking only of the political structure of the government, and do not mean to touch the philosophical question whether the sovereignty has or has not been transferred from the states to the Empire. This point has been the subject of elaborate argument, and in fact the same juristic questions about the origin and nature of the federal government have been discussed in Germany as in the United States. (For a reference to these discussions, see Laband, i. 30-33, 52 et seq., and see especially Jellinek, Die Lehre von den Staatenverbindungen.) Some of the German publicists maintain that the sovereignty resides in the Bundesrath, a vicw which, as Burgess points out in his Political Science (ii. 90-93) is somewhat artificial. For those who think as I do, that sovereignty is not in its nature indivisible, the question loses much of its importance. (Cf. Essays on Government, chapter on the Limits of Sovereignty.) 


\section{The Reichstag}

The Reichstag is elected for five years by direct universal suffrage and secret ballot. ${ }^{2}$ The voters must be twenty-five years old, and not in active military service, paupers, or otherwise disqualified. ${ }^{2}$ The members are chosen in single electoral districts fixed by imperial law. ${ }^{3}$ These had originally a hundred thousand inhabitants apiece, ${ }^{4}$ but they have not been revised for more than a score of years, and with the growth of the large cities have gradually become very unequal. In the case of Berlin the disproportion is enormous, for the city has now over two million inhabitants, but is still represented by only six members. The government, however, is not anxious for a redistribution of seats, because Berlin elects Radicals and Socialists, who form a troublesome opposition - a tendency which is also true of other large centres. As in the United States, no district can be composed of parts of different states, so that every state, however small, elects at least one representative. The three hundred and ninety-seven seats are in fact distributed as follows: Prussia has two hundred and thirty-five, or about three-fifths of the whole number, Bavaria forty-eight, Saxony twenty-three, Wurtemberg seventeen, Alsace-Lorraine fifteen, Baden fourteen, Hesse nine, Mecklenburg-Schwerin six, Saxe-Weimar three, Oldenburg three, Brunswick three, Hamburg three, Saxe-Meiningen two, Saxe-Coburg-Gotha two, Anhalt two, and all the rest one each. ${ }^{5}$ As regards the

1 Cf. Laband, $\$ 34$; Const. Arts. 20, 24. Until I 885 the period was three years.

2 Wahlgesetz, May 3I, I 869, $\$$ I-3. Every voter who has been a citizen of any state for a year is eligible in any district in the Empire without regard to residence. Soldiers in active service, though not allowed to vote, are eligible. (Id., § 4.)
${ }^{3} I d$., $\S 6$.
4 Except in the smallest states.
6 Wahlgesetz, §5; Const. Art. 20; Act of June 25, 1873 (Alsace-Lorraine), $\$ 3$. 
method of election the system of ballotage prevails; that is, an absolute majority is required for election on the first ballot, and if no one obtains this, a second ballot takes place which is confined to the two candidates who have received the largest number of votes. ${ }^{1}$

Universal suffrage was looked upon as an experiment of a somewhat hazardous character, and Bismarck insisted on the non-payment of the members of the Reichstag as a safeguard. ${ }^{2}$ This was a bone of contention with the Liberals for many years - the Reichstag having repeatedly passed bills for the payment of members, which the Bundesrath until rgo6 rejected. ${ }^{3}$ The absence of remuneration was not without effect, for it deterred university professors and other men of small means, usually of liberal views, from accepting an office which entails the expense of a long residence in Berlin; but it did not fulfill the predictions that were made either by its foes or its friends, for it did not cause a dearth of candidates, or discourage the presence of men who made politics their occupation." The provision had, however, a meaning one would hardly suspect. In 1885 , when the Socialist representatives were paid a salary by their own party, Bismarck, claiming that such a proceeding was illegal, caused the treasury to sue them for the sums of money they had received in this way, and, strange to say, the Imperial Court of Appeal sustained the suits. ${ }^{5}$ The object of with-

1 Wahlgesetz, § 12. Lebon (p. 82) thinks this last provision, by cutting out all the candidates but the two highest on the list, favors the government and hampers the free expression of opinion.

2 Const. Art. 32.

${ }^{3}$ In 1906 a measure providing for the payment of members was enacted. Since that date an annual allowance of 3000 marks (about \$750) per year has been paid, with a reduction of 25 marks for each day's absence. The annual allowance is hardly large enough to be termed a salary.

- Blum, pp. 36-37.

- Laband, $\$ 38$; Lebon, p. 78. The members cannot be arrested during 
holding pay from the members was, of course, to prevent the power of the poorer classes from becoming too great; but a much more effectual means to the same end is the habit of holding elections on working days, instead of holding them on Sundays, as is done in France and most of the other Catholic countries.

\section{The Committee System}

The Reichstag has the ordinary privileges of a legislative assembly, electing its own president, making its own rules, and deciding upon the validity of elections. ${ }^{1}$ Its internal organization conforms to the pattern generally followed in continental chambers. At the beginning of each session the members are divided by lot into seven Abtheilungen or sections, which correspond to the bureaux of the French chambers, but differ from these in the important respect that they last during the whole session, instead of being renewed at short intervals. The duties of the sections consist in making a preliminary examination of the validity of elections to the Reichstag, and in the choice of committees, each section electing one or more committeemen, according to the importance of the committee. ${ }^{2}$ As in France and Italy, however, the choice by the sections is really cut and dried beforehand. It is in fact controlled by the Senioren-Convent, a body composed of the leaders of the different parties, who determine in advance the number of seats on the committee to which each party shall be entitled. ${ }^{3}$ Bills are not always

the session except for certain flagrant offenses, and if a criminal prosecution is pending against one of them the Reichstag can order him to be set at liberty (Const. Art. 3r); but in fact it has not always been easy to make this last right effective; Lebon, pp. 34-85.

1 Const. Art. 27.

2 Laband, ii. 327-329. Unlike the French bureaux, their choice is not confined to members of their own section. Lebon, p. 88 .

3 Lebon, $I b$.; Dupriez, i. 526 ; Leband, i. 328. 
referred to a committee; but it is noteworthy that the more advanced Liberals have constantly urged such a reference in the case of government bills, because the authoritative influence of the ministers is thereby diminished, and greater opportunity is given for criticism and amendment; while the more moderate parties, following the lead of the government, have often preferred an immediate discussion of important measures by the full house, without the intervention of any committee at all.

\section{The Powers of the Reichstag}

The powers of the Reichstag appear very great on paper. All laws require its consent, and so do the budget, all loans, and all treaties which involve matters falling within the domain of legislation. It has a right to initiate legislation, to ask the government for reports, and to express its opinion on the management of affairs. ${ }^{1}$ In reality, however, its powers are not so great as they seem. The constitution provides, for example, that the budget shall be annual, ${ }^{2}$ but the principal revenue laws are permanent, and cannot be changed without the consent of the Bundesrath, ${ }^{3}$ while the most important appropriation, that for the army, is virtually determined by the law fixing the number of the troops, and this has hitherto been voted for a number of years at a time. ${ }^{4}$ The chicf function of the Reichstag is, in fact, the considera-

1 Const. Arts. 5, II, 23, 69, 73; Laband, $\S 33$.

2 In 1867 Bismarck wanted triennial sessions, and in 1888 , when the term of the Reichstag was changed to five years, he wanted the sessions held only every other year.

${ }^{3}$ It is to be remembered, moreover, that the bulk of the civil administration is in the hands of the states, which provide the means of carrying it on.

${ }^{4}$ In 1871 , for three years; in 1874,1880 , and 1887 for seven years; and since 1893 for five years, until in 1905 for an indefinite period; and then again in 19 I for five years. 
tion of bills prepared by the Chancellor and the Bundesrath. These it criticizes and amends very freely; but its activity is rather negative than positive, and although important measures have occasionally been passed at its instigation, ${ }^{1}$ it cannot be said to direct the policy of the state either in legislation or administration. ${ }^{2}$

\section{The Right of Dissolution}

The influence of the Reichstag is also diminished by the fact that it can be dissolved at any time by the Bundesrath with the consent of the Kaiser. ${ }^{3}$ In most constitutional governments at the present day the power of dissolution is the complement of the responsibility of the ministers, and is used, at least in theory, to ascertain whether the cabinet possesses the confidence of the nation. But in Germany it exists without any such responsibility, and hence is simply a means of breaking down resistance in the Reichstag. It has, indeed, been used for this purpose on a number of occasions: first, in 1878 , when the Reichstag refused to pass a bill for the repression of agitation by the Socialists; afterwards in I 887 , when it refused to pass the bill fixing the size of the army for seven years; and again in 1893 , when it refused to sanction changes proposed in the military system. In each case the new Reichstag supported the plans of the government, and thus a serious conflict with the Chancellor was avoided, and the question of the ultimate authority of the

${ }^{1}$ A striking example of this was the amendment to Art. 4 of the constitution extending the legislation of the Empire to cover ordinary civil and criminal law.

${ }^{2}$ Cf. Lebon, pp. 113-I 16. The debate on the budget is used as an occasion for criticism of the government, and for the expression of opinion, but in the budget itself few changes are made. The reductions have little importance, while the rejection of an appropriation asked for is extremely rare, and an increase is almost unknown. Dupriez, i. 543-544.

${ }^{3}$ Const. Art. 24. 
different organs of the state was postponed. The last dissolution took place in I 906 because the Reichstag refused to vote the government's colonial estimates.

\section{Interpellations}

The rules of the Reichstag provide for interpellations, but the question to whom these shall be addressed involves one of the paradoxes, or contradictions between theory and practice, which are common in the government of the Empire. There is no imperial cabinet, and the Chancellor, who is the only minister, has no right, as such, to sit in the Reichstag. In theory he comes there only as one of the delegates to the Bundesrath - all whose members have the privilege of being present in the Reichstag, where a special bench is reserved for them. They appear as the representatives of the united governments of Germany, and are entitled to speak whenever they choose; for the Bundesrath is not only a collection of delegates from the governments of the different states, but has also some of the attributes of an imperial cabinet. In form, therefore, interpellations are addressed to the Bundesrath, but in fact they are communicated to the Chancellor, who usually answers them himself, or allows one of his subordinates to do so. A debate may ensue if demanded by fifty members, but it is not followed by an order of the day expressing the opinion of the House, ${ }^{1}$ and, indeed, interpellations have no such importance as in France and Italy, because the parliamentary system does not exist; that is, the Chancellor does not resign on an adverse vote of the Reichstag, nor does he feel obliged to conform to its wishes.

1 Lebon, p. 105; v. Rönne, p. 268. A resolution can, of course, be moved in accordance with the ordinary rules of procedure, and this was done on the occasion of the expulsion of the Poles in Jan. r886. Blum, pp. 498-50r. Dupriez (i. 545) comments on the Polish incident, 


\section{The Bundesrath}

Let us now examine more closely the Bundesrath - that extraordinary mixture of legislative chamber, executive council, court of appeal, and permanent assembly of diplomats. It is the most thoroughly native feature of the German Empire, and has, therefore, a peculiar vitality. The Bundesrath is composed of delegates appointed by the princes of the states and the senates of the free cities; ${ }^{1}$ and it is to be observed that Alsace-Lorraine, which was taken from France in 1871 , was not strictly a member of the union, but only Reichsland or imperial territory, and hence had no right to a representative in the Bundesrath, although as a part of the Empire it elected members of the Reichstag. Its position was in some ways analogous to that of one of our Territories, while the other parts of the Empire correspond to our states. Curiously enough, Alsace-Lorraine was allowed in 1879 to send to the Bundesrath delegates who, like the representatives of the Territories in Congress, could debate, but could not vote; ${ }^{2}$ and finally in I9I I, it was allotted three regular delegates in that body, but as they are appointed by the statthalter who is entirely under the control of the Kaiser - that is the King of Prussia - it was provided that their votes should not be counted when the votes of Prussia would not prevail without them. ${ }^{3}$

The seats in the Bundesrath are distributed among the states and cities in such a way that each of them is entitled to the same number of votes as in the diet of the old

1 Const. Arts. 6-ro.

2 Laband, i. $219^{-2} 20$. In the law of 1879 , as originally drawn up by Bismarck, Alsace-Lorraine was entitled to ordinary delegates to the Bundesrath; but that body, in order not to increase the seats virtually controlled by the King of Prussia, insisted that they should have no vote. Blum, pp. $635-636$. The number of these delegates was four.

${ }^{3}$ Const. Art. 6 a. 
Germanic Confederation when that body proceeded in plenum, except that Bavaria, as part of the inducement to join the Empire, was given six delegates instead of four, ${ }^{1}$ and Prussia obtained those of the states she absorbed in I866. ${ }^{2}$ There are in all fifty-eight members, Prussia having seventeen, Bavaria six, Saxony and Wurtemberg four each, Baden and Hesse three each, Brunswick and MecklenburgSchwerin two each, and the remaining fourteen states and three free cities one each. But Prussia has really three votes more, because the contract for the government of Waldeck already mentioned gave her the vote of that state, and in $1884-85$ she caused the Duke of Cumberland to be excluded from the succession in Brunswick, got a Prussian prince appointed perpetual regent, and thus obtained the virtual control of these two votes also; ${ }^{3}$ so that she has in reality twenty votes out of the fifty-eight. This, of course, is much less than her proportion of the population; ${ }^{4}$ but twenty votes in the same hand count far more than the same number held by different states, and she has only to win ten additional votes - those of Bavaria and Wurtemberg, for example, or those of some of the smaller states - in order to have an absolute majority. In fact, she has usually had her

1 She had six votes in the Bundesrath of the Zollverein from I866 to I87I.

2 Laband, i. 220 . The votes acquired by Prussia in this way were those of Hanover, 4; Hesse Cassel, 3; Holstein-Lauenburg, 3; Nassau, 2; and Frankfort, I.

${ }^{3}$ The Duke was excluded because as son and heir of the late King of Hanover he insisted on his right to that kingdom, and refused to acknowledge its incorporation in Prussia. His son, who married the Kaiser's daughter, has recently been restored to the dukedom.

4 The population of Germany on Dec. I, I9Io, was about sixty-five millions, of which Prussia had forty millions, Bavaria nearly seven millions, Saxony nearly five millions, Wurtemberg two millions and a half, AlsaceLorraine and Baden a couple of millions apiece, Hesse and Hamburg each one million, and the other eighteen states together not much more than four millions. 
way, although on several notable occasions the other states have combined and defeated her. This happened in 1877 , when the seat of the Imperial Court of Appeal was fixed at Leipsic instead of Berlin as she desired; ${ }^{1}$ and in 1876 on the more important question of the imperial railroad law. At that time Bismarck refrained altogether from introducing into the Bundesrath a bill for the purchase of railroads by the Empire, knowing that it would be defeated by the opposition of the middle-sized states, although the project was one on which he had set his heart. ${ }^{2}$ Again, in I 879 , another railroad bill was killed in the Bundesrath by the opposition of Bavaria, Saxony, and Wurtemberg, ${ }^{3}$ and in the same year a conference of the finance ministers of the states refused to consent to the tobacco monopoly. ${ }^{4}$

\section{Character of the Bundesrath}

The members of the Bundesrath are diplomats rather than senators. ${ }^{5}$ They enjoy at Berlin the privileges of foreign ambassadors, and are appointed and removed at will by the states they represent - which also pay them or not as they please. The votes they cast are the votes of the states, not those of its representatives, and it is therefore provided that all the delegates of a state must vote alike. In fact, all the votes belonging to a state are counted without reference to the number of delegates actually voting; ${ }^{6}$

${ }^{1}$ Cf. Blum, pp. I $46-$ I 47 . The vote in favor of Leipsic was thirty to twenty-eight; and it is noteworthy that if Prussia had then controlled the votes of Brunswick the majority would have been the other way.

2 Cf. Blum, pp. 165-I 68 .

3 Blum, p. 345 .

- Blum, p. 3i 2. On this point, however, they yielded some years later.

6 The constitution (Art. Io) provides that the Kaiser shall vouchsafe to them the protection accorded to ambassadors, while the members of the Reichstag have the ordinary privileges of members of a parliament.

- Laband, i. 223. 
and thus the seventeen votes of Prussia, for example, can be cast in her name by a single representative, just as at the meeting of a private corporation a properly authorized agent can vote on all the shares of stock belonging to his principal. The delegates, moreover, vote according to the instructions of their home government, and the constitution expressly declares that votes not instructed shall not be counted. ${ }^{1}$ This last provision has given rise to some comment. It does not mean that a delegate must produce his instructions before he is allowed to vote. On the contrary, the Bundesrath appears to take no cognizance of instructions, which may, indeed, be of any kind, including an authority to vote as the delegate thinks best; and it is even asserted that a vote is valid whether it is in accord with the instructions or not. ${ }^{2}$ The provision in the constitution is probably a mere survival; but it has been suggested that its object is, on the one hand, to allow a delegate to excuse himself from voting on the plea that he has not been instructed, and on the other to make it clear that a vote can be taken, although the delegates have not all received instructions, thus taking away an excuse for delay that might otherwise be urged. ${ }^{3}$

A delegate is usually an officer of the state he represents, often one of its ministers, or even the head of its cabinet, and in any case the ministers of a state are responsible according to its own laws for their instructions to the delegates. ${ }^{4}$ In fact, the ministers are frequently questioned in the local Landtag or legislature, about the instructions they have given, or propose to give; and resolutions are some-

1 Const. Art. 7.

2 Laband, i. 229.

3 Cf. Robinson, "The German Bundesrath," Pub. Univ., Pa. Pub. Law Series, iii. no. I, 34-35.

4 Laband, i. 225-227. 
times passed in regard to them. ${ }^{1}$ If, indeed, the strict parliamentary system existed in any of the German states, the cabinet would no doubt be held responsible to the Landtag for these instructions as for every other act of the government.

Although the delegates are frequently officers of the state they represent, they are not necessarily even its citizens and it is not uncommon for several of the smaller states, from motives of economy, to empower the same man to act as delegate for them all jointly. This habit grew to such an extent that in April, I880, when a stamp act proposed by the Chancellor was seriously amended by a vote of thirty to twenty-eight, thirteen of the smaller states were not represented by any delegates of their own, their votes being cast by two delegates from other states. Bismarck tendered his resignation in disgust, and this caused the Bundesrath to reconsider its action and vote the tax. But the Chancellor was not satisfied. He complained that the practice of substitution deprived the Bundesrath of the presence of members who were open to argument, and he insisted on the adoption of a rule dividing the session into two periods, in one of which the important matters should be considered, and delegates from all the states should be present, while the other should be devoted to current affairs, when the states might appoint substitutes if they pleased. This rule was adopted, and for the convenience of the delegates the former period is made as short as possible. ${ }^{2}$

The Bundesrath is in its nature unlike any other body in the world, and its peculiarities can be explained only by a reference to the diet of the old Germanic Confederation. It

1 Interpellations, for example, were presented and answered in several states in regard to the proposal for the purchase of railroads by the Empire, to which allusion has already been made (Blum, p. 167).

2 Blum, pp. 348-349; Laband, i. 256-257. 
is not an international conference, because it is part of a constitutional system, and has power to enact laws. On the other hand, it is not a deliberative assembly, because the delegates vote according to instructions from home. It is unlike any other legislative chamber, inasmuch as the members do not enjoy a fixed tenure of office, and are not free to vote according to their personal convictions. Its essential characteristics are that it represents the governments of the states, not their people, and that each state is entitled to a certain number of votes which it may authorize one or more persons to cast in its name, these persons being its agents, whom it may appoint, recall, or instruct at any time. The true conception of the Bundesrath, therefore, is that of an assembly of the sovereigns of the states, who are not, indeed, actually present, but appear in the persons of their representatives.

\section{Its Internal Organization}

The internal organization of the Bundesrath is in accord with its federal character and the privileged position of the larger states. We have already seen that the seventeen votes of Prussia are more than enough to defeat any constitutional amendment, and that she is expressly given a veto on all proposals to change the laws relating to the army or the taxes. Besides this, the constitution declares that the Kaiser, that is, the King of Prussia, shall appoint the Chancellor, who presides over the body and arranges its business, through whose hands all communications from the Reichstag and all motions and petitions must pass, ${ }^{1}$ and who is in fact always one of the Prussian delegates. ${ }^{2}$

${ }^{1}$ Const. Art. 15. Cf. Robinson, p. 37.

${ }^{2}$ Most of the German jurists argue that the Chancellor must always be a Prussian delegate, because Art. I5 of the constitution implies that he must be a member of the Bundesrath, and the Kaiser has power to create such 
But the constitution goes into much smaller details in regulating privileges of the states, and prescribes even the composition of the committees; for the Germans have shown a remarkable astuteness in this matter, and nowhere else in the world can we find the important influence of committees in a legislative body so thoroughly recognized. There are eight standing committees of the Bundesrath established by the constitution. ${ }^{1}$ The members of one of these - that on the army and fortresses - are appointed by the Kaiser; but it is provided by the constitution that Bavaria, and by military convention that Saxony and Wurtemberg, shall have places upon it. The members of the committee on maritime affairs are also appointed by the Kaiser; while the committees on taxes and customs, on trade, on railroads, posts and telegraphs, on justice, and on accounts, are elected every year by the Bundesrath itself. On each of the last seven committees, five states at least must be represented, of which one must always be Prussia, whose member is always the chairman. But here again we have an illustration of the fact that the Bundesrath is an assembly of diplomats and not of senators, for the practice followed by the Kaiser or the Bundesrath - whichever has the power of appointment is to designate the states to be represented, and the delegation from each of those states chooses one of its own members to sit on the committee. The seat on a committee belongs, therefore, not to the representative selected, but to the state which he represents. There is one other com-

members only in his capacity as King of Prussia. Laband, i. 253-254; Meyer, Lehrbuch, § I24; Schulze, ii. 91. Hensel (Die Stellung des Reichskanzlers, pp. IO-I2) denies this and quotes Bismarck in his favor. The Chancellor is authorized to commit the duty of acting as chairman to a substitute, and in fact he rarely presides in person. See Dupriez, i. 522, and Blum, p. 143.

1 Const. Art. 8. 
mittee provided for by the constitution - that on foreign affairs. Its functions are peculiar; for it does not report like the other committees, but its members listen to the communications made to them by the Chancellor, and express the views of their respective governments thereon. It is thus in reality a means by which the ministers of the larger states may be consulted upon foreign affairs; and it consists of representatives of Bavaria, Saxony, Wurtemberg, and two other states designated every year by the Bundesrath. As its only function is to consult with the Chancellor, who is virtually the Prussian minister for foreign affairs, Prussia has no seat upon it, and in her absence Bavaria presides. ${ }^{1}$

Another illustration of the federal character of the Bundesrath is to be found in the provision that on matters not common to the whole Empire - such, for example, as the excise on beer, from which Bavaria, Wurtemberg, and Baden enjoy an exemption - only those states which are interested can vote. ${ }^{2}$ There was at first a similar provision for the Reichstag, but it was felt to be inconsistent with the spirit of a national house of representatives, and was repealed. ${ }^{3}$

\section{Powers of the Bundesrath}

The powers of the Bundesrath are very extensive, and cover nearly the whole field of government. It is a part of the legislature, and every law requires its assent. ${ }^{4}$ But, more

1 There are also four standing committees not provided for by the constitution: those on Alsace-Lorraine, on the constitution, on rules, and on railroad rates. All the standing committees may sit when the Bundesrath is not in session. On the subject of the committees, see Laband, 6th ed., I9I 2,8 II, V.

2 Const. Art. 7.

3 Amend. Feb. 24, 1873 .

4 Including treaties that fall within the domain of legislation, Const. Art. I I. Each state las the right of initiative (Art. 7), which is, of course, most frequently used by Prussia. 
than this, it has the first and last word on almost all the laws, for the Reichstag has not succeeded in making its right of initiative in legislation very effective, and by far the larger part of the statutes (as well as the budget) are prepared and first discussed by the Bundesrath. They are then sent to the Reichstag, and if passed by that body, are again submitted to the Bundesrath for approval before they are promulgated by the Kaiser. ${ }^{1}$ The Bundesrath may therefore be said to be not only a part of the legislature, but the main source of legislation.

It is also a part of the executive. As such, it has power to make regulations for the conduct of the administration, and to issue ordinances for the completion of the laws, so far as this power has not been specially lodged by statute in other hands. ${ }^{2}$ In regard to finance its authority is even more extensive, for it has been given many of the functions of a chamber of accounts. ${ }^{3}$ It enjoys a share of the power of appointment, for it nominates, among other officials, the judges of the Imperial Court, and elects the members of the Court of Accounts; while collectors of taxes and consuls can be appointed only with the approbation of its committees. ${ }^{4}$ Under this head of executive power must also be classed the provisions by which its consent is required for a declaration

1 Laband, i. 542; Schulze, ii. I 8.

2 Const. Art. 7. It exercises this power with great freedom. Robinson, pp. 50-53. There is some difference of opinion how far this power extends. Laband, i. 236-237; v. Rönne, i. 213-215; Arndt, pp. II5-119. Arndt has also published a treatise on this subject, Das Verordnungsrecht des Deutsehen Reiches. It is also empowered to decide upon defects that appear in the execution of the laws. Const. $A$ rt. $7, \S 3$. The meaning of this clause has been much discussed. Laband, i. $238-242,246$; v. Rönne, i. 215-216; Arndt, Verfassung des Deutsehen Reiches, p. I19; Robinson, pp. 56-59.

3 Laband, i. $244^{-246 .}$

- Laband, i. 242-243. 
of war, ${ }^{1}$ for a dissolution of the Reichstag, ${ }^{2}$ and for federal execution against a refractory state. ${ }^{3}$ The Bundesrath, moreover, acts in some ways like a ministry of state, for it designates one or more of its members to support in the Reichstag the measures it has approved; and in fact a practice has grown up of informing the Reichstag during the progress of a debate what amendments to a bill the Bundesrath is willing to accept. ${ }^{4}$ But the federal nature of the Bundesrath comes into play again curiously here, for each of the delegates also represents in the Reichstag his particular government, and can express its views, although contrary to those of a majority of the members. ${ }^{5}$

The Bundesrath has no little power of a judicial or semijudicial nature. It decides disputes between the imperial and state governments about the interpretation of imperial statutes. ${ }^{6}$ It is virtually a court of appeal in cases where there is a denial of justice by a state court. ${ }^{7}$ It decides controversies between states, which are not of the nature of private law, if appealed to by one of the parties; ${ }^{8}$ and, finally, when a constitutional question arises in a state which has no tribunal empowered to decide it, the Bundesrath must try to settle it by mediation if requested to do so by one of the parties, or if this fails, it must try to dispose of the matter by imperial legislation. ${ }^{9}$

${ }^{1}$ Except on the ground that an attack has been made on the territory of the Empire. Const. Art. II.

\footnotetext{
2 Const. Art. 24.

3 Const. Art. Ig.

4 Laband, i. 537, n. 5 .

5 Const. Art. 9.

6 This is deduced from Const. Art. $7, \S 3$.

7 Art. 77.
}

${ }^{8}$ Const. Art. 76 . If unfitted to decide the question, it can substitute for itself some other body, and this it did in 1877 in the case of the controversy between Prussia and Saxony in regard to the Berlin-Dresden railroad, selecting the Court of Appeal of Lübeck. Laband, i. 249, note 2.

${ }^{\otimes}$ Const. Art. $76, \S 2$. 


\section{Privacy of Mcetings}

The Bundesrath has not only far more extensive powers than the Reichstag, but it has also certain privileges that enhance its prestige and increase its authority. Thus the Reichstag cannot be summoned to meet without the Bundesrath, whereas the latter can sit alone and must in fact be called together at any time on the request of one third of its members. ${ }^{1}$ Unlike the Reichstag, moreover, the order of business in the Bundesrath is not broken off by the ending of a session, but is continuous, so that matters are taken up again at the point where they were left, and thus its work is made far more effective. ${ }^{2}$ The most important privilege it enjoys, however, is that of excluding the public from its meetings. ${ }^{3}$ This has given it the advantage of concealing to some extent its internal differences, and has enabled it to acquire a reputation for greater unanimity, and consequently to exert more influence than it would otherwise possess. Privacy, indeed, would seem to be almost as essential to the Bundesrath, as to the cabinet in a parliamentary government, or to an Anglo-Saxon jury. It is easy to perceive that the twelve jurors would seldom agree, if the public were allowed to witness the mysterious process of reaching a verdict; and it is equally clear that harmony in the Bundesrath would be very seriously imperiled, if its galleries were filled with spectators. One can imagine how the newspapers

1 Const. Arts. I3-I4.

2 Laband, i. 253.

3 The constitution does not provide whether the sessions shall be public or not, and in fact they have always been secret ( $v$. Rönne, i. 210-2II). A brief report of the matters dealt with and the conclusions reached is given to the press after each session, but the Bundesrath can vote to withhold from the public all information about any matter, and the rules provide that the oral proceedings both in the Bundesrath and its committees shall be kept secret in all cases. Laband, i. 259 . 
would gloat over the last altercation between the Chancellor and the representative of Bavaria or Saxony, and how hard it would be for the contending parties to make the concessions necessary to effect an agreement after their differences had been discussed in public. The work of the Bundesrath must be an unending series of compromises, and compromise is a thing with which the world at large has little sympathy. If, therefore, the meetings of the Bundesrath were open, it would be a hotbed of dissensions between the governments of the different states, instead of a bond of union and a means of mutual understanding.

\section{Actual Influence of the Bundesrath}

In regard to the power and influence actually wielded by the Bundesrath, the most contradictory statements are made. It is said on the one hand to be the most important body in the Empire, ${ }^{1}$ and on the other that it is a mere nullity which moves almost entirely at the dictation of Prussia. ${ }^{2}$ Both these statements are largely true, for considered as an independent council with a will of its own the Bundesrath is a nullity, because it derives its impulse exclusively from outside forces; but, considered as an instrument by means of which the governments of the larger states, and especially of Prussia, rule the nation, it is probably the most important, although the least conspicuous, organ in the Empire. The extent of Prussia's authority in the Bundesrath cannot be accurately determined, owing to the secrecy of the proceedings. That her will, or rather the will of the Chancellor acting in her name, is the chief moving and directing force, is evident; but that he is not influenced by the opinions of the other states, that he does not modify his plans in con-

1 Robinson, p. 43.

2 Lebon, pp. 145-151; Dupriez, i. 478, 517-523. 
sequence of their objections, or make compromises with them on contested points, it seems hazardous to assert. The members are usually wise enough not to talk about their differences in public, and hence these are only partly known to the world. At one time the minister of Wurtemberg complained openly in the Reichstag that bills were presented to the Bundesrath drawn up in a complete form by Prussian officials, and filled exclusively with a Prussian spirit; ${ }^{1}$ but we know that this has not always been the case, and that important measures have frequently been considered and discussed by the ministers of all the larger states before they were introduced at all. ${ }^{2}$ We know also that in more than one instance Bismarck found it impossible to persuade the Bundesrath to adopt his views, and that on one occasion he thought a threat of resignation necessary to compel submission. In this case the threat produced the desired result, but it may well be doubted whether it would have the same effect in the mouth of any one but the Iron Chancellor, whose strong will dominated also the Reichstag and the throne. $^{3}$

\section{The Kaiser}

We now come to the Kaiser. ${ }^{4}$ The title seems to imply an hereditary sovereign of the Empire, but from a strictly legal point of view this is not his position. He is simply the King of Prussia, and he enjoys his imperial prerogatives by virtue of his royal office. There is, in fact, no imperial crown, and the right to have her king bear the title, and exercise the

1 See Blum, p. I 40.

2 This was notably true in the case of the Gerichtsverfassunggeselz in 1873 (Blum, p. I4I).

${ }^{3}$ Lebon (p. 147) thinks that Prussia has a good deal of influence in the appointment of delegates by the other states, and refers to the case where Bismarck procured the recall of the Bavarian representative in 1880 .

1 Cf. Const. Arts. I I-I 9 . 
functions of Kaiser, is really one of the special privileges of Prussia. The language of the constitution is: "The presidency of the union belongs to the king of Prussia, who bears the title of German Kaiser." The succession is therefore determined solely by the law of the Prussian Royal House, and in case of incapacity the Regent of Prussia would, ipso facto, exercise the functions of the office. ${ }^{1}$

\section{His Powers as Kaiser and King}

It has been said that as commander-in-chief of the army and navy the Kaiser has in theory the personal direction of military matters, but that in all others he acts as the delegate of the confederated governments, under the direction of the Bundesrath; ${ }^{2}$ and even if this statement is not strictly accurate, it gives a very fair idea of his prerogatives. He has charge of foreign affairs, makes treaties subject to the limitations already mentioned, and represents the Empire in its relation to other countries, to the states, or to individuals. He declares war with the consent of the Bundesrath, and carries out federal execution against a state when it has been ordered by that body. He summons and adjourns the chambers, and closes their sessions, and with the consent of the Bundesrath he can dissolve the Reichstag. He promulgates the laws, and executes them so far as their administration is in the hands of the Empire, subject, however, to the important qualification that most of the administrative regulations are made by the Bundesrath. He appoints the Chancellor and all other officers, except in cases where the Bundesrath has been given the right of appointment or confirmation; but it must be remembered that the laws are mainly administered by the state governments under federal supervision, and hence there are comparatively few federal

1 Laband, i. 202-204.

2 Lebon, Pp. I 54-1 55. 
officials to appoint. In short, the executive power of the central government is very limited; and even that limited power is shared by the Bundesrath.

The Kaiser has, therefore, very little power as such, except in military and foreign matters. His authority as Kaiser, however, is vigorously supplemented by his functions as King of Prussia. Thus as Kaiser he has no initiative in legislation ${ }^{1}$ and indeed he is not represented in the Reichstag at all; for the Chancellor, strictly speaking, appears there only as a member of the Bundesrath. ${ }^{2}$ But as King of Prussia the Kaiser has a complete initiative by means of the Prussian delegates to the Bundesrath whom he appoints. As Kaiser he has no veto, but as king he has a very extensive veto - for it will be remembered that the negative vote of Prussia in the Bundesrath is sufficient to defeat any amendment to the constitution, or any proposal to change the laws relating to the army, the navy, or the taxes.

His functions as Kaiser and as king are, indeed, so interwoven that it is very difficult to distinguish them. As Kaiser he has supreme command of the army and appoints the highest officers. As King of Prussia he appoints the lower officers, and has the general management of the troops over most of Germany. As Kaiser he instructs the Chancellor to prepare a bill. As king he instructs him to introduce it into the Bundesrath, and directs how one third of the votes of that body shall be cast. Then the bill is laid before the Reichstag in his name as Kaiser, ${ }^{3}$ and as king he

${ }^{1}$ Laband, i. 537. Strictly speaking, the initiative in the Bundesrath belongs to the states, and in the Reichstag it is confined to the members. Laband, i. 534 .

${ }^{2}$ Cf. Lebon, pp. I55-156; Dupriez, i. 534. If, as the German jurists maintain, the Chancellor's right to preside in the Bundesrath depends on his being a Prussian delegate, the Kaiser, as such, is not represented in the Bundesrath at all.

3 Const. Art. I6. 
directs the Chancellor what amendments to accept on behalf of the Bundesrath, or rather in behalf of the Prussian delegation there. After the bill has been passed and become a law, he promulgates it as Kaiser, and in most cases administers it in Prussia as king; and finally as Kaiser he supervises his own administration as king. This state of things is by no means so confusing to the Germans as might be supposed; for it is not really a case of one man holding two distinct offices, but of the addition of certain imperial functions to the prerogatives of the King of Prussia. The administration of the country is vested in the sovereigns of the states, among whom the King of Prussia is ex officio president; and until one has thoroughly mastered this idea, it is impossible to understand the government of Germany. ${ }^{1}$

\section{The Chancellor}

There is no imperial cabinet, and the only federal minister is the Chancellor, who has subordinates but no colleagues. ${ }^{2}$ The reason for this is to be found partly in Bismarck's personal peculiarities, and partly in the nature of the ties that bind Prussia to the Empire. In the first place, Bismarck preferred to stand alone, and did not want to be hampered by associates. He had had experience enough of the Prussian cabinet, where each of the ministers was highly independent in the management of his own department, and he did not care to create for himself a similar situation in imperial matters. After he had decided on a course of action, he hated, as he said, to waste his time and strength in persuading his colleagues, and all their friends and advisers, that his policy was a wise one. Hence he would not hear of an imperial

${ }^{1}$ Schulz (Preussen, in Marquardsen, pp. 33-34) remarks that the two offices are so closely bound together that it is impossible to think of them separately.

${ }^{2}$ Laband, i. 348 ; and see $\S 40$. 
cabinet. ${ }^{2}$ In the second place, he did not originally intend to have any federal ministers at all. According to his plan the general supervision and control of the administration was to be exercised by the Bundesrath, while those matters - such as military and foreign affairs - which, from their nature must be entrusted to a single man, were to be conducted by the King of Prussia as President of the Confederation, all others being left in the hands of the several states. The Chancellor was to be a purely Prussian officer, who should receive his instructions from the king, and be responsible to him alone. ${ }^{2}$ This plan is very interesting, because, although in form it was not accepted, in substance it presents an almost exact picture of the real political situation, except that the power of the Prussian King has become greater than was at first intended. ${ }^{3}$ The Liberals objected to it, and under the lead of Bennigsen the constituent Reichstag amended the draft of the constitution, by providing that the acts of the president ${ }^{4}$ should be countersigned by the Chancellor, who thereby assumed responsibility for them - thus making the Chancellor a federal officer responsible to the nation. ${ }^{5}$ The principle was excellent, but has remained unfruitful; for the Chancellor is not responsible criminally, and Bismarck refused to hold himself politically responsible to any one but the monarch. He always insisted

1 Cherbuliez, L'Allemagne Politique, 2d ed., pp. 228-229. Meyer, in his Grundzüge des Norddeutschen Bundesrechts (pp. 88-97), discusses Bismarck's objections to a collegiate ministry.

2 Lebon, p. 152.

${ }^{3}$ It is a striking fact that the high inperial officials have usually been selected from among the Prussian functionaries. Lebon, p. 157.

- This was in 1867 , before the King of Prussia was given the title of Kaiser.

${ }^{5}$ Const. Art. I7. Unlike matters of military administration, the acts of the Kaiser as commander-in-chief of the army are not treated as requiring a countersignature. Schulze, Lehrbuch, p. 93. 
that the motto "The king reigns but does not govern" had no application to the House of Hohenzollern. In short, the parliamentary system does not exist in the Empire, and the Chancellor is not forced to resign on a hostile vote in the Reichstag. If that body will not pass one of his measures. he gets on as well as he can without it; or, if he considers the matter of vital importance, he causes the Reichstag to be dissolved and takes the chance of a new election. ${ }^{1}$

\section{His Functions}

The Chancellor is at the head of the whole body of federal officials. Besides he is the chairman of the Bundesrath, and is, in fact, its leading and moving spirit. He takes also an active part in the debates in the Reichstag, where he is the chief representative of the policy of the government. But like his royal master he has a double nature, and his functions are partly imperial and partly Prussian. It is as Chancellor appointed by the Kaiser that he is at the head of the national administration, and presides in the Bundesrath; but it is as Prussian delegate that he votes in that body, and indeed his influence there is mainly due to the fact that he speaks in the name of Prussia, and casts as he chooses the twenty votes which she controls. In the Reichstag, on the other hand, he appears nominally as commissioner for the Bundesrath or as one of its Prussian members, while his importance is really due to his position as chief of the federal government.

It is obviously essential to the Chancellor's position that he should be the leader of Prussia's delegation in the Bundes-

I I do not mean that no imperial official has ever been driven from office by the Reichstag. The fall of a minister may be occasionally brought about by the opposition of a popular chamber, although there is no general cabinet responsibility. Prince Maximilian of Baden appointed to negotiate a peace is now insisting (Oct., I9I8) that he is in harmony with the majority in the Reichstag, and that his successors will always be so hereafter. 
rath, and should be able to direct her imperial policy. For this reason the Chancellor, except for short intermissions, has been also the president of the Prussian cabinet; and in fact the policy of combining the two offices may now be looked upon as settled.

\section{His Substitutes}

The powers of the German Chancellor in Bismarck's day were greater than those of any other man in the world, and his work and responsibilities were heavier than even his iron frame could bear. In order, therefore, to relieve him in part, an act was passed in 1878 providing for the appointment by the Kaiser of substitutes, whenever the Chancellor should declare himself prevented from doing his work. These offices were expected at first to be temporary, especially that of Vice-Chancellor, or general substitute, who was intended to act only during the illness of the Chancellor; but with the increase of business they have become a permanent necessity, the Chancellor declaring that he is prevented from doing his work by the fact that he has too much of it to do. For many years there has been a Vice-Chancellor continuously, and it has been the habit to make as many of the secretaries of state as possible special substitutes for their own departments, ${ }^{1}$ appointing them at the same time Prussian delegates to the Bundesrath, in order that they may be able to speak both in that body and in the Reichstag. ${ }^{2}$ The substitutes countersign the acts of the Kaiser in the Chancellor's stead, but are nevertheless subject to his orders, and thus he still remains sole head of the government, and is morally responsible for its whole policy. ${ }^{3}$

1 Dupriez, i. 495-497. The substitution can be made only for those matters which the Empire administers directly. Dupriez, Ib.; Laband, i. $35^{8}$.

2 Dupriez, i. 522.

${ }^{3}$ Laband, i. 359; Dupriez, i. 497-499. The federal administration began 


\section{The Judiciary}

The judicial branch of the imperial government remains to be considered. Justice is administered in the first instance by the state courts; but curiously enough, the organization of these courts is regulated by imperial statutes.' Their rules of practice are also derived from the same source, for the federal government has enacted general codes of civil and criminal procedure, which apply to the state tribunals. ${ }^{2}$ It has, moreover, enacted a universal criminal code, a commercial code, and a general code of civil law; so that there are in each state a similar series of courts organized on an imperial plan and expounding imperial laws in accordance with imperial forms of procedure, but whose members are appointed by the local sovereign and render their decisions in his name.

\section{The Reichsgericht}

Apart from administrative and consular courts, there is only one federal tribunal, called the Reichsgericht, or Court of the Empire. It has original jurisdiction in cases of treason against the Empire, and appellate jurisdiction from the in a very simple form, for there was only one chancery office (Bundeskanzleramt), divided into three sections, the Prussian officials doing in some departments a good deal of federal work. But as the number of affairs to be attended to has grown, the federal machinery has become more elaborate. The general chancery office has disappeared, and there are now many separate departments, each with a secretary of state, or president of a bureau at its head. Such are the Interior, Foreign Affairs, Navy, Post Office, Justice, Treasury, Railroads, Colonies, Invalid Funds, Debt Commission, and Imperial Bank. Laband, 6th ed, $\S$ I3, iv.

1 The Gerichtsverfassunggesetz of Jan. 27,1877 . Laband, $\$ 86$, and see $\S 8 \mathrm{I}$. This is true only of the ordinary courts of law, the subject of administrative courts being left for the most part in the discretion of the several States. See Laband, ii. 368 .

2 The Civilprozessordnung of Jan. 30, 1877. The Strafprozessordnung of Feb. I, 1877 . 
federal consular courts and from the state courts on questions of imperial law. ${ }^{1}$ It is to be observed, therefore, that with the completion of the system of national codes the imperial tribunal has become a general court of error in all cases arising under the ordinary civil or criminal law. ${ }^{2}$

\section{Character of the Federal System}

To sum up what has been said, the German Empire is a federal government of a peculiar type, in which legislative centralization is combined with administrative decentralization. The centre of gravity is to be found in the body representing the governments of the several states, and here Prussia has a controlling influence, and a veto on the most important matters. In fact, the Confederation is not a union of states with equal rights, but rather an association of privileged members, so contrived that Prussia has the general management, subject only to a limited restraint by her associates. And herein there is a marked contrast between the American and German federal systems. That of the United States is based on the equality of the members; and a decided preponderance on the part of any one state would destroy the character of the union. That of Germany, on the contrary, is organized on a plan that can work successfully only in case one member is strong enough to take the lead, and keep the main guidance in its own hands. ${ }^{3}$ This Prussia does by its king, by the Chancellor whom he appoints and by its influence in the Bundesrath.

1 Laband, $\$ 84$.

2 A state which has several courts of error can create a supreme court of appeal and confer upon it the appellate civil jurisdiction of the Reichsgericht, but this has been done by Bavaria alone, and only to a limited extent. Laband, 6th ed., p. 341, note 2.

${ }^{3}$ Cf. Dupriez, i. $475^{-477}$. 


\section{CHAPTER $\mathrm{X}$}

GERMANY: PRUSSIA AND THE SMALLER STATES

THE interlacing of the powers of the Kaiser as such and as King of Prussia has already been illustrated by the process of enactment and execution of a federal statute. Another striking example may be found in the military institutions of Germany. The navy is, indeed, an imperial force wholly under imperial management and control. One might suppose that this would be true also of the army if one looked only at the provision in the constitution that the whole land force of the Empire shall form a single body under the command of the Kaiser in war and peace; and yet German jurists disagree on the question whether the Empire has legally any troops at all, or has only a right to direct the troops of the several states. ${ }^{1}$ Except for certain privileges reserved to Bavaria, the Empire in fact prescribes the obligation of military service, the regulations for the recruiting, organization and discipline of the troops and the qualifications for officers. It determines the number of men in time of peace, and appropriates the money for their maintenance; while the Kaiser, as commander-in-chief, appoints the highest officers, approves the appointment of generals, directs the garrisoning of fortresses, and has the right of inspection. On the other hand, the monarchs of the several states have charge of their contingents, conducting the military administration thereof, expending the appropriations voted by the Empire, and appointing all the other officers. The authority of the King of Prussia is, moreover, distinctly greater than

1 Laband, Deutsches Reichstaatsrecht, 6th ed., $\$ 40$, p. 356, n. I. 
this statement would lead one to suppose, so great as to give him practically the management of the troops over most of Germany; for, save where imperial military regulations are made, those of Prussia must be followed by the other states; and in fact all the states, except Bavaria, Saxony, and Wurtemberg, have by contract transferred their forces bodily to Prussia. The administration of the troops is, indeed, so completely in the hands of the states that there is no imperial minister of war. Certainly the military functions of king and Kaiser are inextricably combined.

With such an organization and distribution of powers, it is obviously very difficult for any representative assembly to exert a substantial control over the administration or conduct of the army, the more so as the military orders of the Kaiser, both as imperial commander-in-chief ${ }^{1}$ and as King of Prussia, ${ }^{2}$ are not countersigned by any minister, and are, therefore, not regarded as political acts for which anyone is responsible to the legislative bodies. The only serious control possessed by the Reichstag is over the size of the army, and this is regulated by laws covering usually five years at a time.

\section{Prussia: The Constitution and the King}

The close interlocking of powers in Germany between the central government and the states makes a brief description of the institutions of the latter necessary for an understanding of the system. Of these states by far the most important is the kingdom of Prussia.

The present constitution of Prussia was drawn up by the king in 1849 , submitted for revision to the legislature elected in accordance with its provisions, and promulgated in Jan-

1 Laband, id., p. $35^{8}$, n. 3 .

2 v. Rönne, Das Staatsrecht des Preussischen Monarchic, 4th ed., i. 418; Meyer, Lehrbuch, p. 187. 
uary, I850. It can be amended by a majority vote in each of the two chambers, sanctioned by the king, but this has not been done since I888. The method in its creation was in accord with its character. It was not the work of the people but of the crown whose authority, although limited thereby, is not derived from it, or based upon it. In fact, German jurists constantly assert in Prussia, ${ }^{1}$ and for that matter in other states of the Empire, that the monarch is the sovereign possessor of all residual political authority; the representative bodies having only the powers specifically assigned to them by the constitution. Except, therefore, for the limitations imposed by that document - chiefly in requiring for statutes and appropriations the consent of the legislature - the royal authority is regarded by jurists as absolute. There is, indeed, a provision that the acts of the king must be countersigned by a minister who becomes thereby responsible for them; ${ }^{2}$ but in the absence of any duty to resign at the request of the chambers the political responsibility is only to the king himself. Moreover, his acts as commander-in-chief of the Prussian troops and as head of the Evangelical Church, and his addresses to the chambers, are not in practice countersigned at all.

\section{The Ministers and the Bureaucracy}

The king acts, of course, through his ministers, but unlike the chief officers of state in most countries at the present day, they are singularly independent of one another, sometimes differing considerably in their public policy. ${ }^{3}$ There is, indeed, a minister president, but he has no real control over his colleagues; and there is a collective ministry of state,

\footnotetext{
1 E.g., Schulze, Preussen in Marquardsen, pp. 41, 42.

2 Const., Art. 44.

${ }^{3}$ Cf. Dupriez, i. 36 r, 363.
} 
but it has little legal and scarcely more moral authority. ${ }^{1}$ One can readily see that such a system of ministers, independent of each other in their several departments, but strictly responsible to the king, tends to enhance the personal power of the monarch if he has the will and capacity to exert it. Although the ministers are not responsible to the legislature, they have the right, universal in the German constitutional states, of appearing and speaking in either chamber, a privilege which they use constantly.

Subordinate to the ministers is the bureaucracy, which is certainly a highly efficient body of officials. The qualifications and examinations for appointment to this corps of civil servants are strictly prescribed and observed, and membership is permanent; while discipline is maintained by special tribunals composed of administrative officials whose consent is required for dismissal without a pension. ${ }^{2}$ Under the Prussian system of minute regulation of the everyday life of the citizens, such a body of men has great power; and owing to the habit of not appointing Social Democrats and other opponents of the government to public office that power tends strongly to support monarchical, conservative, and autocratic principles. The authority wielded by the bureaucracy would probably be regarded as oppressive were it not for three facts; first, that the people like to be controlled in their daily life to an extent that would be resented among us; second, that the officials are not excessively tied down by routine or minutely directed from above, but are allowed a considerable latitude for the exercise of their own discretion; and third, that in their dealings with the public they are subject to the jurisdiction of a series of administrative courts, a majority of the members of the lower ones being

\footnotetext{
1 Cf. Id., pp. $367-37$ I.

2 v. Rönne, $\$ 251,256,260,264,387$.
} 
private citizens elected by the local representative bodies, while the highest is composed of men appointed by the king for life with the ordinary judicial security of tenure.

\section{The Landtag}

The Landtag, or legislative body of Prussia, consists of two chambers, the Herrenhaus, or House of Lords, and the Abgeordnetenhaus, or House of Representatives. Its normal life is five years, but the lower chamber may at any time be dissolved by the king. It must be summoned to meet every year, and all statutes, taxes, loans and the yearly budget require its consent. Most of the Prussian jurists, however, teach the doctrine that, as the popular chamber has not a right alone to repeal the laws, it cannot produce the same result by refusing the funds required for their execution. ${ }^{1}$ This doctrine was put into effect by Bismarck in the budgetless years preceding the War of 1866 , and perhaps might be again. The Landtag has a right to initiate legislation, but in fact most bills are introduced by the government, so that its chief activity consists in the consideration and amendment of measures submitted to it by the ministers of the crown. We may add that the influence of the Landtag upon the conduct of the public administration by the royal officers is not large.

The House of Lords consists of about three hundred members, of whom more than one third are hereditary, landowning nobles, and another third, life members nominated by landholders; so that the body is in fact controlled by the landed gentry, a class that has a marked character in Prussia.

1 Cf. Schulze, pp. 102-104; Gneist, Die Militärvorlage von 1892 und der Preussische Verfassungskonflikt. The authorities are collected and discussed by Laband, ii. 993-995, 1037 et seq.; v. Rönne ( $\$$ II 8 ) is of the contrary opinion. Compare in this connection, Const., Arts. 100, Iog. 
It is vigorous, resolute, jealous of its rights, conservative in temperament, military in spirit, and devotedly loyal to the throne. It can be relied upon, therefore, to reject any changes proposed by the other house which the king does not approve; but is by no means ready to follow him in a liberal policy. The greater part of the remaining members are appointed by the king for life; a few on the nomination of certain bodies, but most of them at his pleasure. These last are unlimited in number and thus the king can control the house in case of need. The point is important, because if the king should, in case of popular upheaval, think the preservation of his dynasty depended upon taking the popular side, he could legally overcome any opposition on the part of the upper chamber.

The House of Representatives is composed of four hundred and forty-three members, elected by a suffrage which, though substantially universal for all men twenty-four years old, ${ }^{1}$ is neither equal nor direct. One cause of inequality is that there has been little change in the electoral districts for nearly sixty years, in spite of the great growth of the cities within that period. Berlin, for example, with more than one twentieth of all the people of the kingdom, had its number of representatives raised in I 906 only to twelve, or to about one-half its ratio to population; the reason being, of course, the radical tendencies of its citizens. A second cause of inequality in the suffrage is the three-class system of indirect election.

\section{The Three-Class System of Election}

The representatives are elected in districts each of which is entitled, as a rule, to two members, but often only to one,

1 The Constitution says twenty-five years old, but the Ordinance of May 30, 1849, which regulates the procedure, says twenty-four. 
and sometimes to three. The voters in the district do not, however, vote directly for the representatives, but for electors chosen in smaller areas into which the district is subdivided. To these lesser areas, one elector is allotted for every two hundred and fifty inhabitants, and the voters are separated into classes for the purpose of choosing them. The first class is composed of the largest taxpayers who together pay one third of the aggregate direct taxes; the second of the next largest taxpayers who pay another third of these taxes; the third class comprises all the rest of the voters who pay the remaining third of the taxes. Each of these classes chooses separately one-third of the electors to which the subdivision is entitled. All the electors chosen in the subdivisions then meet together and elect the representative, or representatives, of the district by absolute majority vote. It follows that the first two classes can wholly control the election.

The effect of the system may be gathered from the statement that in more than two thousand of the subdivisions the first class consists of only one man, and in nearly as many more it contains only two men. In $\mathrm{I}_{907}$, it was estimated that about three per cent of all the voters of the kingdom belonged to the first class, about nine and one-half per cent to the second, and the remaining eighty-seven and one-half per cent to the third; so that on the average, less than thirteen per cent of the voters, comprising the richest people, had an absolute control of an election to the popular chamber. ${ }^{1}$ The system was devised in order to give everyone a share in the direction of public affairs, while retaining for property and the bearing of the public burdens, as compared with mere numbers, a special weight in the apportionment of power; and it does so with a vengeance. In a country where

1 Ogg, The Governments of Europe, pp. 259-260. 
the social and political cleavage between the different classes is so sharp as it is in Prussia the results are very striking. Two recent elections will illustrate this. In 1903, the Social Democrats cast almost as many votes as the Conservatives, but they did not elect a single representative, while the Conservatives elected one hundred and forty-three. At the next election in 1908, the Social Democrats polled nearly one quarter of all the votes cast and elected only seven of the four hundred and forty-three representatives. The effect of the three-class system is increased by the fact that the ballot is not secret - a matter that is deemed of no small importance in Germany on account of the opportunity it gives to the government and to employers to exert pressure on the voters.

There has long been a persistent agitation for a change of the electoral laws, the more radical elements demanding the entire abolition of the three-class system, together with direct elections and secret ballot. At last the government became convinced of the need of some reform, and in igio introduced a bill for the purpose; but as it merely lessened instead of removing the objections to the system, it did not go far enough to satisfy even the moderate reformers, and was finally lost by a disagreement between the houses. ${ }^{1}$ During this war, the government has again promised reform, but has not as yet overcome the stout opposition of the landed gentry. Their repugnance to a radical change is the more comprehensible because equal, direct and secret suffrage would, in the present social conditions in the country, lead to far-reaching changes. It would transfer from them to quite a different class the centre of gravity of political power, and would no doubt be followed by a demand that the ministers should be politically responsible to the popular chamber,

' Ogg, pp. 262-263. In 1913, they elected only ten. 
thereby changing the whole character of the monarchical institutions and of the system of administration depending thereon.

\section{Prussian Local Government}

The principle of placing political power under the control of property, rather than of numbers, is applied throughout the Prussian government, local as well as central. Everywhere there are elected councils, and everywhere the lion's share in choosing them lies in the hands of the wealthier classes. In the cities the municipal council is usually elected by the three-class system, while in the rural districts all elected bodies are, as a rule, chosen directly or indirectly by the Kreistag. This is the assembly of a local area called the Kreis, and it is elected partly by municipal councils, partly by the larger taxpayers and partly by the rest of the voters on a complicated plan so arranged that the great majority of citizens elect only a minority of the members. The system of local government is efficient, but it is not democratic, and, in the cities at least, tends to aggravate rather than reduce social discontent. ${ }^{1}$

\section{Bavaria}

Bavaria is the second largest state in the Empire, and its political institutions, ${ }^{2}$ although differing much in detail from those of Prussia, and showing marked traces of French influence dating from the Napoleonic period, illustrate the pervasiveness of German principles of government. The electoral franchise is far more popular than in Prussia, yet the personal authority of the king, and the relation of the legislature to the ministers and the administration, are very

1 For a fuller description of Prussian local government, see the writer's Governments and Parties in Continental Europe, i. 308-333.

2 v. Seydel, Bayericshes Staatsrecht, igr 3. 
much the same. The Landtag is composed of two chambers. The first, unchanged since $18 \mathrm{I} 8$, contains royal princes, crown officers, high ecclesiastics, mediatized nobles and members appointed by the king in heredity or for life, with a provision that the life appointments shall not exceed one-third of the body. The House of Representatives is chosen under laws that have constantly become more democratic. The constitution of 1818 provided for election by several different classes of voters; that of 1848 substituted a universal equal suffrage of all taxpayers twenty-five years of age, but the election was indirect and the ballot was not secret. In I88I the ballot was made secret; in I906, the election was made direct, and in 1907-1908, payment of the members was introduced. The districts are not alike in size, but the suffrage is otherwise now substantially universal, equal, direct, and secret so far as the central legislature is concerned. In the local government, on the other hand, except in the cities, the larger taxpayers are still given a special share of power.

In spite of the extended suffrage the ministers are not politically responsible to the popular chamber. For years the majority of that chamber, which until I893 was almost continuously in the hands of the clerical party, strove to bring about such a result; but they did not succeed, and their failure proves that in Germany a democratic system of election does not necessarily bring the government under popular control. One would suppose that an elected chamber, holding the power of the purse, could, if it chose, compel an hereditary monarch to select ministers in accordance with its wishes. But it has not done so in Bavaria; nor was the failure due to a peculiarly conservative attitude on the part of the crown; for during the period in question, the ministers, although not always in harmony among them- 
selves, and by no means the representatives of any party, pursued, in the main, a decidedly liberal policy. The result shows the persistence of the monarchical principle in Germany.

\section{Wurtemberg, Baden, and Hesse}

Like Bavaria, the other southern states ${ }^{1}$ were more affected than the northern by the principles of the French Revolution, and of late years they have likewise made their elections more truly representative of the whole people. Yet the control of the monarch over administration and his leading influence in legislation are the same that prevail universally in Germany. The composition of their upper chambers is of the usual type, except that in addition to the official, hereditary and appointed members, there are a few elected representatives of trade, industry, and commerce.

Until I 906 , the lower house in the kingdom of Wurtemberg consisted of nine ecclesiastics, of the chancellor of the university, of thirteen members elected by the landowning nobility, and of seventy other members elected in single districts by manhood suffrage and secret ballot. Twenty years ago, this body was in two respects unique in Germany. In no other Landtag composed of two chambers did the popular branch contain privileged members, and in no other were members elected by direct universal suffrage. The first of these peculiarities has now ceased to be true of Wurtemberg; the second has ceased to be peculiar and is true in all four of the South German states. By an act of Igo6, the twenty-three privileged members were abolished in Wurtemberg, and all the members are now elected by universal direct suffrage and secret ballot. Sixty-nine of them are chosen in

1 Göz, Das Staatsrecht des Königreichs Würtemberg, 1908; Walz, Das Staatsrecht des Grossherzogtums Baden, 1909: v. Calker, Das Staatsrecht des Grossherzogtums Hessen, 1913. 
single districts, while the remaining twenty-three are divided among three large districts where they are elected by the free list system of proportional representation.

In the Grand Duchy of Baden, on the whole the most liberal of the German states, the suffrage has long been substantially universal and the ballot secret; but until fourteen years ago the election instead of being direct was conducted by means of electors, a method which in the opinion of the Germans themselves does not give a free expression to popular opinion. In 1904 this was changed, and the election was made direct. Curiously enough the cities have rather more than their proportion of the members.

The conditions were much the same in the Grand Duchy of Hesse, where the elections were also indirect until igir. The members are now chosen for six years, one half retiring every three years, in single districts, directly, by secret ballot of all men over twenty-five years of age who pay any direct tax; a slight conservative tendency being shown in the provision that men over fifty have two votes.

As in the case of Bavaria, a widely extended suffrage has not as yet caused the ministers in these three states to be responsible to the majority of the elected chamber; although on the whole their governments have pursued a liberal policy. ${ }^{1}$

\section{Saxony}

The changes in the composition of the Saxon representative chamber during the last century reflect in an illuminating way the shifting currents of political opinion in Germany. ${ }^{2}$ The mediaeval estates were replaced in $18_{3} \mathrm{I}$ by

1 There are, in all three states, provisions whereby divergent action of the two chambers on certain matters, chiefly financial, may be settled. This is done by a joint sitting, or by counting the aggregate votes in both bodies.

${ }_{2}$ Mayer, Das Staatsrecht des Königreichs Sachsen, I909. 
a Landtag or legislature of two chambers. The upper one which has remained substantially unchanged, was made to consist, in accordance with the common German custom, of royal princes, ecclesiastics, nobles, representatives of the landed gentry and the cities, and of members appointed by the king for life. The other chamber has undergone several transformations. In the year following the general European upheaval of 1830 , an act was passed whereby it was composed of twenty members elected by the landed gentry, twenty-five each by the cities and the peasants, and five (later ten) by the traders and manufacturers. The next great popular upheaval in 1848 produced for the moment a revolutionary change, and a law of that year brought direct election by manhood suffrage. But the movement soon spent its force and the law was repealed in 1850 . The war of 1866 and the creation of the federal Reichstag on the basis of manhood suffrage, caused that electoral principle to prevail again in Saxony. The representatives of the gentry were transferred to the rural districts and those of trade to the cities, so that the chamber consisted of eighty members elected practically by all men twenty-five years of age, voting in single districts by direct and secret ballot. Except for the fact, usual in Germany, that the cities were underrepresented, the system was certainly democratic. It lasted for a quarter of a century until that bugbear of German statesmen, the growth of the Social Democratic party, brought about a change. The elections to the Reichstag in I 893 made it probable that under the existing franchise this party would obtain a majority of the seats in the Saxon chamber; and to prevent such a result, an act was passed in I 896 establishing in a modified form the three-class system of Prussia. The reason given for the change was the usual German argument that electoral rights ought to be propor- 
tional to taxation. But prolonged agitation and a feeling that the restriction had gone too far brought in 1909 another and more complicated plan to limit democratic tendencies. It was based upon the principle of multiple votes. The chamber now consists of ninety-one members elected in single districts by direct and secret ballot. Every citizen twenty-five years of age who pays any direct taxes has one vote. If he pays taxes upon an income, ranging from i $25^{\circ}$ to I600 marks according to its source, or owns two hectares of land or half a hectare of garden or vineyard, or has a secondary school education, he has two votes. If he pays taxes upon an income ranging in the same way from 1600 to 2200 marks, or owns more land, he has three votes; if the income is from 2200 to 2800 marks, or the land is larger still, he has four votes. Men over fifty years of age have an additional vote, on the theory that age is conservative; but no one has more than four votes in all. This plan is more democratic, and has proved distinctly less favorable to the privileged classes than that of Prussia, for at the election that followed its adoption, the Social Democrats carried nearly one-third of the seats; whereas, under the three-class system they had carried only one.

The king has the customary powers of a German monarch, and as is usually the case, legislation is mainly initiated by his ministers. There is, moreover, a curious provision in the constitution that a measure introduced by the crown is adopted if one chamber passes it and the other rejects it by less than a two-thirds vote.

\section{The Small Monarchies}

The example of Saxony shows either that the tendency towards popular government is by no means so strong in the north of Germany as in the south, or that it is counterbal- 
anced by a dread of Social Democracy. With some notable exceptions this is true of the fourteen small northern constitutional principalities. No one of these contains more than half a million inhabitants, and some of them far less. Yet in each of them the ruler exercises the usual monarchical powers. Each has a Landtag consisting of a single chamber, which contains in most cases, beside the representatives of the people, members appointed by the crown, or representatives of privileged classes who might otherwise sit in a separate house. On account of the minute size of these states and their correspondingly small influence on the current of German political life, any changes in their organization are important only so far as they throw light on the tendency of political thought. But such changes as have taken place of late years are hardly general enough for this purpose. In Oldenburg, ${ }^{1}$ indeed, and Saxe-Weimar, the election of representatives was made direct in 1909 instead of through the medium of electors, and at the same time, the suffrage in Oldenburg was extended; while in Brunswick, ${ }^{2}$ on the other hand, where the ducal crown is practically under the control of the King of Prussia, a modified form of the Prussian threeclass system of election for the popular representatives has been introduced. This last is not, however, so reactionary a change as it might appear, for the Landtag had previously been elected by the municipal and communal councils which were chosen under a form of local government resembling that of Prussia. In the other small constitutional monarchies no very significant changes have taken place.

1 Schücking, Das Staatsrecht des Grossherzogtums Oldenburg, $191 \mathrm{I}$.

2 Rhamm, Das Staatsrecht des Herzogtums Braunsi'eig, 1908. 


\section{The Two Mecklenburgs}

In Gemany, political institutions certainly become less democratic as one travels north; and on the shores of the Baltic the two Grand Duchies of Mecklenburg-Schwerin and its much smaller sister Mecklenburg-Strelitz have an organization that remains truly mediaeval. These two states are a case of political Siamese twins, for although the Grand Dukes are independent sovereigns, there is a common Landtag. This body consists of two estates, that of the owners of knights' fees, all of whom (some eight hundred in number) have a right to sit; and that of deputies from the municipal authorities of the cities. The powers and procedure of the estates are also archaic. An example of this may be seen in the conduct of debates where everyone speaks whenever and as long as he pleases, so that in moments of excitement no less than twenty members have been known to speak at once - a habit that tends, no doubt, to save time. The survival of these ancient forms of government is not approved even in Germany, and the Grand Duke of Mecklenburg-Schwerin himself has on several occasions sought to create a modern representative legislature, but has been prevented from doing so by the refusal of the landowning knights to give up their privileges.

\section{Hamburg, Bremen, and Lübeck}

There remain the three hanse cities which are the only members of the German Empire republican in form, although that by no means implies a democratic organization. ${ }^{1}$ The institutions of these city-states differ much in detail, but the general plans are so far alike that they can well be described together. Each has a Senate and a Bürgershaft,

1 Bollmann, Das Staatsrecht der Freien Hansestädte Bremen und Lïbeck, I9I4. 
the two bodies forming together the legislature; while the Senate is the principal factor in the administration, which it carries on largely through committees. It is, in fact, treated in national affairs as the sovereign of the state. The senaators, fourteen, sixteen, and eighteen in number, are chosen for life by a complex procedure in which both the Senate and Bürgerschaft take part.

The Bürgerschaft is a much more numerous body, one hundred and twenty in Lübeck, one hundred and fifty in Bremen, and one hundred and sixty in Hamburg. The members are chosen for six years, one-third or one-half retiring every two or three years. In Bremen the methods of election have been little changed since 1854 ; while in Hamburg and Lübeck they have been altered several times, the last changes having been made in 1906 and 1907. In all three cities, however, care is taken to keep the control in the hands of the more conservative and wealthier people. Bremen has the least undemocratic system. Here every citizen may obtain political rights as a bürger by paying a small fee, but the representatives are elected by eight classes of voters so arranged that eighty-two are chosen by persons possessing educational or business qualifications, and sixty-eight by the rest of the citizens. In Hamburg and Luibeck the electoral rights of a bürger can be acquired only by citizens who have paid an income tax for five consecutive years, and then the voters are divided into classes based upon educational, official, business, or property qualifications, so that in Hamburg only twenty-four, and in Lübeck only fifteen are elected by the poorer citizens. In the case of Lübeck the new system is far less democratic than that which prevailed in the latter half of the last century.

The effect of such a distribution of political power has been much the same as in the large Prussian cities. Munici- 
pal affairs are efficiently conducted, but the fact that in all three cities the deputies elected to the Reichstag by universal suffrage are Social Democrats - a clear indication in Germany of political discontent among the working classes - seems to show that the system does not satisfy a large section of the people.

\section{Alsace-Lorraine}

When, after the war with France, the French provinces west of the Rhine were ceded to Germany in $187 \mathrm{I}$, they were in an anomalous and unfortunate position. The violent objection of the inhabitants to the annexation, and their consequent hostility to the Empire, forbade any idea of creating a new state with the autocracy and privileges of the other members of the confederation. On the other hand, a proposal to incorporate the provinces with any existing state would have aroused jealousy; nor could any state, except Prussia, have annexed them without serious danger to its own internal tranquility. The only possible course, therefore, was to treat the country as a dependency of the Empire, under the direct control of the imperial authorities. With this object the Act of June 9, I87 I, gave the executive power to the Kaiser, reserving the legislative for the Bundesrath and Reichstag. In response, however, to a demand for some measure of self-government, an imperial decree of October, I874, created an elected Landesausschuss, or assembly, and in 1877 a statute was passed providing that laws for AlsaceLorraine might be enacted by the Kaiser without the consent of the Reichstag, if the Bundesrath and the Landesausschuss agreed to them. Two years later another statute gave the Landesausschuss a right to originate legislation, and authorized the appointment of a statthalter or governor, to exercise the powers previously confided to the imperial 
Chancellor. Laws might nevertheless still be made for the province by the Bundesrath and Reichstag, which were thus enabled to disregard local opinion entirely if they pleased.

The statthalter was, and still is, appointed and removed at pleasure by the Kaiser, to whom he is directy subordinate. He is in fact the minister for Alsace-Lorraine, and as such countersigns the acts of the crown. He governs by means of a secretary of state and four heads of departments; and is assisted by a council of state with merely advisory powers.

In local matters the old French system was in the main preserved, all the executive officials being appointed by the government, and the local councils being elected by universal suffrage. In regard to the central officials, on the other hand, the German law was introduced which protects them from arbitrary removal.

The provinces participated to some extent in the government of the Empire for they elected fifteen representatives to the Reichstag, and after I879 the statthalter was authorized to send to the Bundesrath delegates who could speak but not vote. ${ }^{1}$

The motives for annexing Alsace-Lorraine were chiefly military, but there was also no little talk about restoring the long-lost brothers to the German family. The brothers, however, although for the most part German by descent and language, cried piteously at being united to the Fatherland, and the government was obliged to use its utmost energies in trying to reconcile them to their lot, to Germanize them and to transplant Germans among them. French writers declare that nothing has been accomplished in changing the sentiments of the people, while the Germans insist that if the result has not been wholly satisfactory the progress has been very considerable.

1 Leoni, Elsass-Lothringen, in Marquardsen. 


\section{The Act of IgII}

The demand for autonomy in Alsace-Lorraine grew more and more insistent. Its spokesmen asked that the internal legislation of the province should be freed from the control of the Bundesrath and placed in the hands of a legislature of its own; that the executive authority should be transferred to an independent head of some kind; and that the province should become fully a state of the Empire. At last the government determined to yield the first of these demands, and to some extent the third was forced upon it by the Reichstag during the discussion of the bill. The second has not been granted at all. The act of May 3I, IgI I, ${ }^{1}$ provides that Alsace-Lorraine shall be treated as a state of the Empire for the purpose of sending delegates to the Bundesrath. ${ }^{2}$ But as already pointed out the votes of its three delegates to that body are not to be counted when needed to give Prussia a majority, or the minority required to reject certain measures. The act declares that the sovereignty is exercised by the Kaiser, who appoints and removes for the purpose a statthalter. He in turn appoints and instructs the delegates to the Bundesrath, countersigns the acts of the Kaiser, and has under him, at the head of his administration, a secretary of state.

The legislation for the province is entrusted to a Landtag of two chambers. The first contains the bishops and other high church dignitaries; the president of the highest court; representatives elected by the university, the chief cities, chambers of commerce, agriculture and labor; and members appointed by the Kaiser for the term of the Landtag, not

1 In his sixth edition of $1912, \$ 22$, iv. v. 23. Laband discusses this act, and prints the greater part of it in an appendix.

2 Laband $(\S 22, v$.) notes this as evidence that Alsace-Lorraine is not a full state, but only treated as such for certain purposes. 
exceeding in number the other members. The second chamber is elected for five years by universal, direct and secret ballot. The Kaiser must summon the chambers to meet every year, but can dissolve either of them. All their acts require his consent, and there is a provision that if the Landtag fails to vote the budget, the government can make expenditures previously authorized by law or needed to carry on the administration. It may be noted also that the second chamber cannot increase any appropriation in the budget laid before it without the consent of the government, and that the first chamber can only accept or reject the budget as it comes from the second. The Landtag has full power to initiate other laws; and the Kaiser has the usual authority to issue ordinances with the force of law when the public safety requires it and the Landtag is not in session. Except in the case of financial measures, the relations between the chambers and the ruler are in fact modeled upon those usual in German monarchies. For fear, however, of French influence it is provided that the German language must be used in the Landtag, and, save in exceptional cases, in the schools and by the public officials.

The new constitution has not been in operation long enough before the war to produce definite results, but the first Landtag elected showed an independent spirit disconcerting in high places at Berlin. 


\section{CHAPTER XI}

\section{GERMANY: COMMENTS ON THE POLITICAL SYSTEM}

AfTER having surveyed the political structure of the Empire and the states, we are in a position to examine the actual working of the federal government. This may be said to turn upon the relation of the Chancellor to the other organs of state; for, like a central wheel that is geared to all the others, the Chancellor comes into direct contact with each of the imperial authorities.

\section{The Position of the Chancellor}

It is clear that the Chancellor would occupy an absurd position if he were confined to the matters that belong strictly to his office, for he would be the chief minister of one of the greatest nations in the world, and yet his powers would be insignificant. Apart from foreign affairs, the navy, and the selection of a few high officers, his executive duties would be almost entirely limited to watching over the administration of the imperial laws by the several states, and seeing that they complied with the ordinances and regulations issued, not by him, but by the Bundesrath. In regard to legislation, moreover, his very lack of executive powers would prevent his exerting an effective control. Representing strictly in his capacity of Chancellor neither the King of Prussia nor the confederated sovereigns, he would be unable to acquire any considerable authority in the Bundesrath. He would, it is true, preside over that body; but simply as chairman he would be in a situation not much better than that occupied by the vice-president in the Senate of the 
United States. Unless he could also speak in the name of Prussia, and cast her votes, he would have very little influence with the menibers, and could neither guide legislation nor direct the policy of administration. In order, therefore, that the Chancellor may be a real minister of state, and not a mere inspector and honorary chairman, he must be at the head of the Prussian delegation in the Bundesrath. But the delegation receives its instructions from the Prussian government, and it would be irrational for the Chancellor to be given instructions by men whose policy differed from his own. Hence he must be in absolute accord with the Prussian government, so far as these instructions are concerned. Nor is this all. The friction between the Chancellor and the Prussian cabinet would be intolerable if the latter were to administer the imperial laws in a hostile spirit; and indeed the relations between the Empire and the kingdom are interwoven in such a way that the machinery of state can work smoothly only on condition that, so far as they deal with the same matters, both governments are conducted in harmony, and this can be true only in case both are directed by a common will. Now, in view of the fact that the Chancellor is the sole head of the imperial administration, while the Prussian ministers are seldom completely united, it is hardly conceivable that they should be able as a body to control his actions; and if one of their number should acquire a predominant influence in public affairs, he would find it almost impossible not to be the Chancellor. Unless, therefore, the Kaiser has the desire and the capacity to keep the personal direction of both the imperial and the royal government in his own hands, the Chancellor must be also the leading minister in Prussia.

These observations about the position of the Chancellor in the Bundesrath apply with equal force to his position in the 
Reichstag. A minister of state has an influence over an elected chamber because he represents the government, and a Chancellor who can speak at the same time in the name of the federal administration, of the Prussian state, of the confederated sovereigns, and of the upper house of the legislature, has enormous authority at his back. But if he possessed only his very limited powers as imperial aclministrator; if someone else represented and cast the rotes of Prussia in the Bundesrath, so that he was powerless there, he would be impotent in the Reichstag also. It follows that with the present intricate connection between Prussian and imperial affairs, the system can work well only as it was designed to work, by placing both in the same hands.

\section{Why not Responsible to the Reichstag}

There is another and quite different relation possible between the government and the representatives of the people, it is that of the parliamentary system, where the power of the minister comes from his speaking in the name not only of the government but also of the majority in the assembly. In that case his authority is doubled. There are many reasons why such a relation has not grown up in Germany. One of them has been the vitality of the monarchical principle there; another is to be found in the interlacing of powers which makes the enforcing of responsibility to any one popular body extremely difficult; and there is a third that merits further consideration. A parliament holding the strings of the public purse, and meeting with tolerable frequency, has in its hands the means of compelling the monarch through his ministers to govern according to its wishes, and whether it does so or not depends very much on the condition of its political parties. If the members are divided into two parties only, so that one or other of them always 
has a majority, the parliament is certain in time to bring the crown under its control; but if there are a number of small groups, it is much easier for the government, by making from time to time special concessions to one or more of them, to secure a majority on all important occasions, and thus remain independent. This is the case in the Reichstag.

\section{Parties in Germany}

The bitter conflict between the King of Prussia and the House of Representatives, which reached its height shortly after Bismarck became chief of the cabinet in September, I862, and lasted for the next four years, consolidated the different political elements in the Chamber into two hostile bodies - the supporters and the opponents of the government. The former, who shrunk at times to a mere handful of members, were called the Conservatives, while their antagonists belonged for the most part to a new organization known as the Fortschritt or party of progress. The decisive victory over the Austrians at Sadowa wrought a sudden change in public opinion. Instead of the tyrannical despiser of popular rights, Bismarck appeared in the light of the champion of German unity and even of liberty, and the result was a breaking up of the old party relations and a rearrangement of the political groups on a new basis. ${ }^{1}$ The Conservatives, who had supported the government, ceased to be unpopular, and regained the seats they had lost; but, what is more important, each of the great parties split in two. A number of the Conservatives, who were more progressive in opinion than their fellows, and more in favor of the new federal system, left the party to organize another under the name of Free Conservatives; ${ }^{2}$ and, on the other hand, a

${ }^{1}$ See the articles on the parties in the Reichstag in Unsere Zeit, by Oppenheim (1880, i) and Johannes Berg (1882, i, ii; 1883 , ii).

${ }^{2}$ Called later the Deutsch-Reichspartei. 
body of men, including the most influential leaders, separated themselves from the Fortschritt, and formed the National Liberal party. These men were less dogmatic than their former associates, were more inclined to sacrifice the ideal for the practical, and, above all, had more confidence in Bismarck.

Thus two new middle parties arose, the four groups corresponding fairly well to the four divisions into which, according to the theory of Röhmer, ${ }^{2}$ all mankind is naturally divided - the Reactionaries, the Conservatives, the Liberals, and the Radicals. Each of the four has continued to exist under one name or another ever since the formation of the North German Confederation; for although some of the members have often broken away and formed new groups, these have disappeared after a short time, or been absorbed by one of the older bodies. It is therefore worth our while to consider these parties a little more closely. The two extreme ones - the Fortschritt and the Conservative - were almost exclusively Prussian; the Conservatives being recruited chiefly among the lesser nobility or Junkers, and the Fortschritt in the larger towns and cities. The Free Conservatives also came mainly from Prussia, the core of the party being the greater nobility, from whom the ambassadors and other high officials were mostly selected. The National Liberals, on the other hand, extended far more into the other parts of the Empire, and included during their era of prosperity almost all the deputies from the smaller North. German states, and most of the men of liberal views from the South. This has been, indeed, the only truly national party that the Empire has ever known, all the other groups being mainly local, or founded on questions of race, of sect, or of class, rather than on general political issues.

2 Lehre von den Politischen Parteien. Cf. Bluntschli, Charakter u. Geist der Pol. Parleien. 
The various kinds of particularists so-called are based mainly on questions of race. They are irreconcilables, who complain that their province or their race has been unjustly treated, and has been forced into a union repugnant to its feelings. The most important of them are the Poles, the Hanoverian Guelphs, the Danes, and the Alsatians, all few in numbers, but uncompromising fighters. On the question of religion is founded the Catholic party or Centre, which arose when Bismarck entered upon his quarrel with the Catholic Church; but which has continued with undiminished strength ever since, although the original cause of its formation disappeared long ago. At the opposite end of the social scale from that of the conservative landowners there was later formed among the workingmen the party of the Social Democrats. Recruited primarily from the discontented classes in the large cities it has spread so widely over the country that it can claim to be considered a national party.

\section{Parties in the Landtags}

It is worth while to observe here that the parties in the Prussian Landtag have always been similar to those in the Reichstag - except, of course, for certain groups like that of the Alsatians, which belong exclusively to other parts of the Empire; and, in general, it may be said that in each state the parties for national and local politics are very nearly the same, so that every party in the Reichstag corresponds to a local party in one or more of the states, and every considerable local party appears in the Reichstag either as a separate group by itself, or as part of a larger organization. It is not, however, possible to say that the parties are divided as in France, on national issues, or, as in Italy, on local ones, because neither class of issues has a predominant influence; and, in fact, owing to the peculiar apportionment of power 
between the federal government and the states, the same question, as for example that of the rights of the Catholic Church, is presented both in the Reichstag and in the Landtags.

\section{Class Strife an Obstacle to Popular Government}

The condition of the classes has had a momentous effect on political development. The Prussian nobility have never stood like the English as defenders of the lowly against the crown. On the contrary, the crown has been the shield of the peasants against the oppressions of the great landowners. The nobles, moreover, have belonged wholly to one political party, so that Prussia has never known that division of its aristocracy into Liberals and Conservatives, each furnishing leaders to the people, which has been of such inestimable value in England. It is, in fact, the strife of noble with peasant, of city with country, compelling everyone to look to the king as an arbiter, that has given to the crown, and the bureaucracy as its tool, so great an influence and renown. ${ }^{1}$ The same cause must continue to produce the same effect, and so long as the royal authority endures at all it can hardly fail to be strong unless a great party is formed which finds hearty support in every rank of life, and can speak in the name of the people without distinction of class.

The material is not well adapted to the formation of great parties, for the Germans are so little homogeneous, and their traditions of thought are so diverse as to hinder any large part of the people from working together for a common end. One is constantly struck by the contradictions in the different phases of German character. Side by side with the dreamy, mystical turn of mind, there is a talent for organiza-

1 This was also true at one time of the monarchy in France, but hardly to so great an extent as in Germany. 
tion and a submission to discipline that have made them the first military people of the day. Again, we are apt to attribute to German scholarship a peculiarly agnostic tendency, and yet no rulers in Christendom have the name of God so constantly on their lips as the German Kaisers. Nor is there the least affectation or cant about this, for the Germans are at the same time one of the most religious and one of the most skeptical of races. The fact is that the people are divided into strata, social and intellectual, which are very different from one another in character and tone of thought. The various classes are, indeed, separated by an almost impassable gulf. ${ }^{1}$ At one extremity we find the noble landowners of Prussia, who form an aristocracy of the most exclusive type. They are conservative by temperament, military by taste and education, and the privilege which the officers still retain in most of the Prussian regiments of admitting as comrades only such men as they choose has enabled this class to keep the bulk of the offices in the army in its own hands. At the other end of the social scale are the workingmen, and these on account of their very isolation are peculiarly prone to socialism. Between the two extremes stand the commercial classes and the Jews, who are despised by those above them, and disliked by those below. The geographical differences are also strongly marked in Germany. The south and west were far more thoroughly imbued with the principles of the French Revolution, and are far more democratic to-day, than the older parts of Prussia. The Prussians also are less German, as we commonly understand the German character, than the rest of the people. They are more practical, more military, and more bureaucratic; and hence the sympathy even between

1 See an interesting article entitled "Society in Berlin," by Professor Geffcken, in the New Review, August, 1892. 
the corresponding classes in different parts of the country is by no means complete.

\section{The Growth of Discontent}

Two opposite forces have been growing in Germany of late years: one is the belief in military monarchy, which has received no little support among scholars; the other is a spirit of discontent, which has made great headway among the lower classes; and between the two the liberal elements have been pushed into the background. ${ }^{1}$ In fact, both of these opposing forces derive much of their strength from a common source. The change from a theoretical to a practical point of view, that has lent potency to the doctrine of military monarchy, applies not only to politics, but also to private life, and here it has replaced the enthusiasm for ideal and intellectual aims by a craving for material prosperity and well-being. ${ }^{2}$ The result has been an immense increase in the power of the Social Democrats. It would be a great mistake, however, to suppose that all the men who vote for the Socialist candidates agree with their doctrines. Probably a small part of them do so ${ }^{3}$ but the autocratic policy of the government, the burden of service in the army, and the difficulty of earning a comfortable living, have made a great many people discontented, and these vote the Socialist ticket as the most effective method of protest. The size of the Socialist vote is, therefore, a measure of the amount of discontent in Germany, and as such it is highly significant; but what will happen if the Social Democrats become strong

${ }^{1}$ Cf. Bamberger, "The German Crisis and the Emperor," New Revien", April, 1892.

2 Viscount Bryce comments on this in "An Age of Discontent," Contemp. Rev., Jan., I89I.

${ }^{3}$ Cf. Bamberger, supra; and this has been increasingly true since he wrote. 
enough to exercise a controlling influence on politics is by no means clear. With their increase in numbers in the Reichstag, their leaders have become less violent, and power is likely in the future to bring moderation.

\section{Democracy would Involve Organic Changes}

The intricate connection between the Prussian and the federal machinery, which works smoothly so long as both are in the hands of a single man, would hardly be possible if the people became the real source of power. Suppose, for example, that the Reichstag succeeds in compelling the Kaiser to select a Chancellor who enjoys its confidence; ${ }^{1}$ suppose in other words, that the Chancellor really becomes politically responsible to the Reichstag, but that in Prussia the king remains free to choose his ministers as he pleased. It is clear the government can be made to work smoothly, only on condition that the spheres of action of the Chancellor and the Prussian cabinet become independent of each other, and this will involve a practical abandonment by the latter of all interference in federal matters.

Again, suppose that the Landtag should also acquire the power to make the ministers responsible to itself; and with its present organization it is highly unlikely that such a privilege would be won by the Prussian House of Representatives, without being obtained by the Reichstag as well. In this case, the functions of the Chancellor and the Prussian ministers might continue unchanged for a time; but even if the same party controlled both bodies, so that the executive officers were its instruments both in Prussia and the Empire, it is not probable that they would long hold themselves responsible to two separate assemblies. The Reichstag, as

1 The new Chancellor, Prince Maximilian of Baden, has asserted in the reply to President Wilson, and in his speech to the Reichstag, that this is now, and will continue to be, the case. 
the representative of a wider public opinion, would gradually assume the decisive authority in national questions, and hence Prussia would either become merged in the Empire, or else her government would be confined to local affairs. In either event, the Chancellor would probably cease to be in any degree a Prussian officer, and would acquire a purely federal character. The Bundesrath also would suffer a severe loss of influence if the Chancellor became responsible to the Reichstag; and it has shown its appreciation of this more than once in objecting to the creation of responsible federal ministers. The Chancellor would no longer speak to it as the delegate of Prussia, but as the representative of the Reichstag. In short the Bundesrath would fall to the subordinate position occupied by the upper chamber in all countries with a parliamentary form of government. It would not only lose the legislative authority it now wields, but it would hardly be suffered to retain the power to make executive ordinances and regulations, and so direct the policy of the administration. Until such changes occur, popular government in Germany can hardly be considered on a permanent foundation. 


\section{CHAPTER XII}

\section{AUSTRIA-HUNGARY}

THE spirit of the French Revolution was in its essence humanitarian. It disregarded the narrow distinctions of race and country, proclaimed the universal brotherhood of man, and offered to all the world the blessings of its creed. Yet the great political movements to which it gave rise have brought about an increase of race feeling so great that peoples of different blood can no longer live peaceably together under the same government, and the various branches of a race are unhappy until they are all covered by a single flag. Race, in other words, has become a recognized basis of nationality; and this has produced in Europe two new states, and loosened the bonds of two old ones. The ties of blood have united Italy and Germany; while England has gravely debated a,plan for a partial separation between the Saxons and the Celts, and Austria has become very seriously disintegrated under the strain of racial antipathies.

\section{Provinces and Races of Austria}

In order to understand the institutions of Austria, it is necessary to know something of its peculiar geography and ethnology. The official designation of the western half of the monarchy - which for convenience I shall call simply Austria - is "the Kingdoms and Lands represented in the Reichsrath," "and the name implies the utter lack of unity

${ }^{1}$ Cf. Staatsgrundgesetz über gemeinsame Angelegenheilen (Dec. 2r, 1867), i; Ulbrich, Oesterreich, in Marquardsen, p. 14. Gumplowicz contends that the use of the name Austria for the western half of the monarchy is correct. Das Oesterreichische Staatsrecht, p. 45, note 42. 
in the nation. Austria is, in fact, a sort of residuum, consisting of all the territory which belonged to the Empire at the time of the compact with Hungary, and did not form a part of that kingdom. The country has a most irregular outline, touching the Lake of Constance on the west, extending on the north into the heart of Germany by means of the province of Bohemia, stretching one long arm eastward above and even beyond Hungary, and another far to the south along the coast of the Adriatic.

This curiously shaped state is divided into seventeen provinces, all enjoying extended political powers, and almost all the theatre of struggles between two or more of the different races. ${ }^{1}$ Some idea of the number of distinct races in the Empire can, indeed, be gathered from the fact that on the assembling of the Reichsrath, or parliament, it has been found necessary to administer the oath in eight different languages. $^{2} \quad$ Yet these include only a small part of the tongues and dialects that are spoken in the land. Among the many races that inhabit Austria there are, however, only five important enough to have a marked influence on politics. These are: first, the Germans, who comprise scarcely more than a third of the population, but possess a much larger share of the wealth and culture. They are scattered more or less thickly all through the country, and predominate along the Danube and in the provinces immediately to the south of it. Second, the Bohemians, or Czechs, who are the next most powerful racc, and compose a majority of the people in Bohemia and Moravia. Third, the Poles, who

1 I call these divisions provinces for the sake of simplicity. Technically, some of them are termed kingdoms, others grand-duchies, arch duchise, duchies, counties, etc. Cf. Staalsgrundgeselz ïber Reichsiertrelung, I; Geller, i. 78 .

2 "Austria: its Society, Politics, and Religion," Baroness de Zuylen de Nyevelt, Nat. Rev., Oct., 1891 . 
form a compact mass in Galicia. Fourth, the Slovenians and other Slavs, living chiefly in the southern provinces in the direction of Triest and Dalmatia. And fifth, the Italians, who are to be found in the southern part of the Tyrol, and in the sea ports along the Adriatic. The numbers of the various races in Austria, according to the census of IgIo, are as follows:

Germans...

Czechs and Slovaks............. 6,435,983

Poles...................... 4,967,984

Ruthenians.................. 3,518,854

Slovenians ................. I, 252,940

Serbs and Croats.............. 783,334

Italians.................... 768,422

Others................ 647,157

$28,324,940$

\section{The Constitution}

The division of the people into several different races is one of the most important factors in Austrian politics, and we shall return to it later; but first the political organization of the country must be explained. When this was remodeled after the war with Prussia, five statutes - all bearing the date of December 2I, I867, - were passed, and termed the Staatsgrundgesetze, or fundamental laws of the state. ${ }^{1}$ They are, in fact, the constitution of Austria, and can be changed only by a two-thirds vote of both houses of Parliament. $^{2}$

1 Ulbrich, pp. I I, I6, Gumplowicz, $\$ \$ 25-27$. These five laws are commonly cited by their titles, which indicate their contents. They are as follows: (1) Staatsgrundgesetz über die Reichsvertretung (R. G. B. I4I). (2) St. G. über die allgemeinen Rechte der Staatsbürger (R. G. B. 142). (3) St. G. über das Reichsgericht (R. G. B. 143). (4) St. G. über die Richterlichegewalt (R. G. B. I44). (5) St. G. iiber die Regierungs- und Vollzugsgewalt (R. G. B. 145).

2 That is a vote of two thirds of the members present. One hundred members constitute a quorum of the lower house in other cases, but for this 


\section{The Emperor}

The powers of the Emperor are legally much the same as in other constitutional monarchies. The fundamental laws declare that he governs by means of responsible ministers, ${ }^{1}$ and by statute all his acts must be countersigned by a minister of state. ${ }^{2}$ Practically, however, the ministers are the servants of the crown, and not of the parliament, and hence the Emperor of Austria can really use his powers with great freedom. This result is due to the incessant quarrels between the different races, which are too bitterly hostile to combine, while no one of them is strong enough to rule alone - a state of things that makes it easy for the government to play them off against each other, and have its own way. In theory the parliamentary system is in force, but in practice the Emperor is so far from being a figurehead that since the present constitution was adopted he has actually refused to sanction a bill passed by both houses of Parliament. ${ }^{3}$ Moreover, there was a parliamentary deadlock from I897 to I904, during most of which the government was carried on without parliamentary assistance, by virtue of a provision in the constitutional laws which authorizes the crown to make ordinances that have provisionally the force of law when the Reichsrath is not in session. ${ }^{4}$

The Reichsrath or parliament of Austria consists of two chambers, of which the upper one, called the Herrenhaus or House of Lords, is composerl of the princes of the imperial family, of the archbishops and prince-bishops, of the heads purpose the presence of one half the members is required. St. G. Reichsvertretung (as amended by the Act of April 2, I873), § 15 .

1 St. G. Regierungsgewall, $\$ 2$.

${ }^{2}$ Law of July 25 , I867, I (R. G. B. IOI).

${ }^{3}$ This was the bill on Monastic Orders passed by the Reichsrath in 1876 .

- St. G. Reichsvertretung, \& 14 . 
of those noble landowning families to which the Emperor grants an hereditary seat, and of members whom he appoints for life. ${ }^{1}$ The lower chamber, called the House of Representatives, is elected for six years, but can be dissolved at any time by the crown. ${ }^{2}$ The members were formerly chosen by the provincial diets. ${ }^{3}$ This proved, however, to be a source of constant annoyance, because some of the races which were struggling for a greater degree of independence insisted that the Reichsrath did not legally represent the nation, on the ground that the fundamental laws had never been properly enacted, and whenever one of those races obtained control of a diet, it would refuse to allow the representatives to be chosen. The trouble with the refractory diets was finally brought to an end on April 2, 1873, by an amendment to the fundamental law in the Reichsrath, whereby the diets were deprived of all part in the matter, and the election was placed entirely in the hands of the provincial voters. The House of Representatives was formerly elected by a highly complicated system of five different classes of voters; but in 1896 , additional members of the House were added, to be elected by universal suffrage, and in 1907 , the classes of voters were abolished altogether and there was substituted a universal suffrage for all men over twenty-four years of age and resident within their districts a year, the seats being at the same time increased to five hundred and sixteen. These seats are divided among the different races roughly in proportion to the taxes they pay, the districts being arranged to comprise so far as possible only racial groups that are essentially homogeneous - in some places, such as Bohemia, where the population is par-

' St. G. Reichsvertretung, $\S \S 2-5$.

${ }^{2} I d ., \S \S 18,19$. This power has been used frequently.

' $I d ., \S 7$. 
ticularly mixed, separate constituencies being created for the electors of each race. ${ }^{1}$

The powers of the Reichsrath extend only to matters falling within its competence, and that is limited by the privileges vested in the provincial legislatures. These privileges are secured by the fundamental laws, which declare that all matters not specially placed under the control of the Reichsrath are reserved for the diets of the provinces. ${ }^{2}$ Austria, therefore, while theoretically a unitary state, has in practice very much the aspect of a confederation.

\section{The Proinces}

Some of the provincial diets are turbulent bodies, and it has often required a stern exercise of authority to keep them within bounds. The power of the Emperor to control them is, indeed, very great. Not only do their measures require his sanction, ${ }^{3}$ which is often refused, but he also appoints the presiding officer, who arranges the order of business, ${ }^{4}$ can forbid the consideration of any matters not within the competence of the diet, ${ }^{5}$ and when so directed by the crown can close the session or dissolve the diet at any time. ${ }^{6}$ This right is used very freely; and it has not infrequently happened in periods of great excitement, when a diet has become a centre for political agitation, that a session has been closed almost as soon as it was opened.

It has been said that although Austria is virtually a federal state so far as legislation is concerncd, yet as regards the

1 Ogg, The Governments of Europe, pp. 469-472.

2 St. G. Reichswcrtretung, $\$ \S$ I I, I 2.

3 E.g., The Landesordnung, of Feb. 26, I86I, for Lower Austria, § 7 .

'Id., $\$ \$ 4$, 10, 36 . This officer in most of the provinces is called the Landmarschall; in others the Landeshauptmann, Präsident, or Oberstlandmarschall.

- Id., $\$ 35$.

- $I d ., \&$ ro. 
executive branch of the government, which in the Empire is the more important of the two, it is centralized, because the provincial executive is not responsible to the diets. ${ }^{1}$ To a great extent this is true; for numberless matters that form a part of the general administration are in the hands of a statthalter or Landespräsident, appointed by the crown, and independent of local control. ${ }^{2}$

\section{The Race Question}

We have seen how many different races there are in Austria, and it is not too much to say that each of them is not only anxious to be entirely free from control by others, but if strong enough wants supremacy for itself. It is, therefore, clearly impossible to content them all, and the policy has been a sort of makeshift that contents none of them. The most powerful, the richest, the best educated, and the most widespread of the races, is the German, which assumes that Austria is, and ought to be, essentially a German country. This people would like to see its own tongue the official language in all the provinces; but although the most powerful of the nationalities, it has been weakened by a division into Liberals and Clericals, and still more by the tendency of the Liberals to fight among themselves.

It is needless to say that the other races do not agree to the assumption that Austria is essentially German. On the contrary, they are incessantly striving for greater recognition of their own rights. The most important of them, because the most numerous and the most aggressive, is that of the Czechs of Bohemia and Moravia. They demand what they call the restoration of the Crown of Saint Wenceslaus

' Karel Kramar, "La Situation Politique en Austriche," Ann. de l'Ecole Libre des Sci. Pol., r89r, p. 662.

${ }^{2}$ Cf. Law of May I9, I868 (R. G. B. 44). 
which means a union of Bohemia, Moravia, and Silesia as a separate kingdom, connected with the rest of Austria only by a tie similar to that which binds Austria and Hungary together.

The next most influential race is that of the Poles, who have the advantage of forming a compact mass in a single province, and who have had the wisdom to understand the true basis of political power in Austria. They see that their fortunes must depend on the goodwill of the crown, and hence they are ready to vote with the government on important measures, in consideration of favors at home. Although they are divided in Galicia into an aristocratic and democratic party, they present a united front at Vienna; and as it is known that they are ready to assist any government that treats them kindly, all parties are willing to buy their support with concessions.

The other important races in Austria, the Italians and the southern Slavs, have had their hands pretty well filled by the quarrels among themselves and with the Germans. 'The Italians from the southern Tyrol would, indeed, like their part of the province separated from the rest; but the Slovenians and the other Slavs have been for the most part too anxious for help from the central government to pursue an active policy of disintegration.

The problem of race in Austria is extremely difficult. Two methods of dealing with it can be imagined. One of them is the creation of a centralized government, in which the Germans, like the Magyars in Hungary, should play the part of the dominant race and force the rest of the people to adopt their language, their habits, and traditions. Such a solution might, perhaps, have been possible at one time if the Germans had possessed the vigor and tenacity of the Magyars, if they had acted solidly together, and if they had been con- 
sistently supported by the crown. But an attempt to carry out this policy has long been hopeless. The other method of dealing with the problem would have been that of breaking up the Empire into a confederation based upon the different nationalities. But this would have been like trying to divide a cake among several children, one of whom wanted the whole of it, while another claimed a half, and three or four more were crying for a quarter apiece. The fact is that the races are not separated by sharp geographical boundaries. Except in Galicia ${ }^{1}$ and the southern Tyrol the races are almost everywhere more or less intermingled, few districts being inhabited solely by one nationality, and the whole of no race living in a separate region by itself. Yet in any part of the country where it predominates, and sometimes where it does not, each race would like to be supreme. Clearly some compromise is unavoidable. Whether any middle course between centralization and disintegration can be successful, it is hard to say; but whatever policy is pursued, it is clear that no durable solution of the problem can be reached until the people have learned to regard it as permanent and legitimate. This sounds tautologous, but it is really important.

\section{Hungary: the Races}

There are four leading races in Hungary, the Magyar, the Slav, the German, and the Roumanian. ${ }^{2}$ The oldest of these is the Roumanian, which claims to have sprung from the Roman colonists and the Romanized natives near the mouths

1 Even in Galicia the Ruthenians, who belong to the poorer class, claim distinct racial rights.

${ }^{2}$ By the census of Igro, the numbers of the races in Hungary were as follows: Magyars, 10,050,575; Germans, 2,037,435; Slovaks, 1,967,970; Roumanians, 2,949,032; Croats and Serbs, 2,939,633; Others, 941,842. Total, $20,886,487$. 
of the Danube, and the members of the race certainly speak a language that has a close affinity with Latin. They live in the eastern part of the kingdom, and are especially numerous in Transylvania. By religion, they belong partly to the Orthodox Greek Church, and partly to the so-called United Greek Church - a body formerly Orthodox Greek which has become united to the Roman Church, but has retained the married clergy and the right to pronounce the liturgy in the vernacular.

The Slavs are, no doubt, the next most ancient race in Hungary, although the precise time of their migration into the country is obscure. They are now broken up into two distinct branches, that of the Slovaks in the north; and that of the Croats and Serbs, who inhabit Croatia, in the southwest, and extend along the whole southern border of the kingdom. Croatia, indeed, whose population is almost wholly Slav, was never completely incorporated in Hungary, and although subject to the Hungarian king after I I02, kept its national institutions, and was governed by means of a ban or viceroy and a separate diet of its own. The Slavs are divided into Catholics, and Orthodox and United Greeks.

The Teutonic hordes that swept over Hungary at the time of the downfall of the Roman Empire of the west have left no permanent traces, and the Germans who live there to-day are descended from the more peaceful immigrants of later times. They are found in considerable numbers in the cities throughout the centre of the land from west to east, but nowhere do they form the bulk of the population, except in certain parts of Transylvania.

The Magyars, who live chiefly in the vast plains that cover the centre and west of Hungary, although a minority of the whole people, are the most numerous and by far the most powerful of the races. They have ruled the country 
ever since their first invasion at the close of the ninth century, and in fact they regard it as peculiarly, and one may almost say exclusively, their own. The fact that the Magyars are not Aryans has probably been one of the chief causes of their failure to assimilate the other races, but in some ways it has been a source of strength. It has prevented them from looking for support and sympathy, like the Germans and the Slavs, to their kindred in neighboring countries, and thus by making them self-dependent has increased their cohesion and intensified their patriotism. ${ }^{1}$

\section{The Hungarian King}

The monarch, who bears in Austria the title of Emperor and in Hungary that of King, presents to the Parliament before his coronation a diploma containing a promise to maintain the fundamental laws and liberties of the land; and this is published among the statutes. He has the ordinary powers of a constitutional sovereign, but these are somewhat more carefully guarded than usual, on account of the anomalous position in which the country has stood so long. ${ }^{2}$ In his case the requirement of a countersignature is no mere formality, for the cabinet is far less subject to the control of the crown than in Austria, and is in fact really responsible in the parliamentary sense of the term.

\section{The Hungarian Parliament}

The Parliament (Orszaggyiules) is composed of two chambers, which bear the ancient names of the Table of Magnates (Förendihár) and the Table of Deputies (Képviselöhár).

1 Ulbrich, pp. I49-1 53 .

2 The right to bear the title of Apostolic King was conferred by Pope Sylvester II in Iooo upon Stephen of Hungary, the royal convert to Christianity. 
The Table of Magnates, as the name implies, is an old and aristocratic body. The Table of Deputies is a representative chamber containing four hundred and fifty-three members. Of these forty are elected by the diet of Croatia, and take part only in matters that affect their province; for Croatia has a right to regulate a large class of subjects in its own diet, and is to that extent independent of the legislature at Buda-Pesth. Hence there are, as it were, two parliaments, a smaller one which attends to all matters that relate to Hungary in the narrower sense of the name, and another, formed by the addition of the members from Croatia, which deals with the subjects that concern the whole kingdom. The Table of Deputies for Hungary proper contains, therefore, four hundred and thirteen members, and these are elected on a limited suffrage which favors the Magyars.

Although the Magyars form less than one half of the population of Hungary, they are more energetic, more aggressive, and better organized than the other races; and the restricted suffrage, the oral voting, and the arrangement of electoral districts tell so strongly in their favor, that except for the forty members from Croatia they hold all but about a score of the seats in Parliament. Moreover, they have long been the ruling caste, and have the habit of command. They feel that Hungary belongs to them, and although since I 848 they have admitted men of other blood to a share of political power, they do not intend to let the control slip from their own hands. No line is drawn between the races in the sense of excluding any person from civil or political rights on account of his birth. The test of citizenship, the qualifications for the franchise, are the same for every one; and in fact the Magyars do not want to keep the other races distinct and in subjection: they propose to absorb them all, and make Hungary a homogeneous nation of Magyars. 
With this object they have insisted on proclaiming Magyar the national language. It must be exclusively used in Parliament, except by the members from Croatia who are allowed to speak in their own tongue. It is the official language of the administration, the courts, and the university, and it must be taught in the public schools.

This does not apply to Croatia whose people were too homogeneous and too strong to be treated in quite so highhanded a manner. The field left to the local authorities there includes education, police, the administration of justice, and a large part of the ordinary civil and criminal law. The province has its own organs of government, the most important of which is the diet, or legislature. This body must be summoned every year, but can be adjourned or dissolved at pleasure by the king, and requires the royal sanction for the validity of its acts. In saying this, however, it must be remembered that the powers of the king are really exercised by the Hungarian cabinet at Buda-Pesth. Croatia is thus an integral part of Hungary, but has retained a considerable amount of autonomy, and differs in this from every other part of the kingdom.

\section{The Dual Monarchy}

The first connecting link between Austria and Hungary is the monarch himself, whose functions in the two countries are, however, carefully distinguished. He begins his reign with two separate coronations - one at Vienna, where he takes the oath before the Reichsrath, the other at BudaPesth, where he is crowned with curious symbolic rites, full of oriental pomp. This dualism is carried out even in his title; for the Magyars are great sticklers about form in matters that involve a recognition of Hungary's equality with the rest of the monarchy. By an order of Novermber I4, 
I868, he is styled "Emperor of Austria, King of Bohemia, etc., and Apostolic King of Hungary." ' 1 The Emperor-King has the command of the joint army and navy; supervises the administration of matters common to both countries, and has power to make ordinances in regard to them. $\mathrm{He}$ appoints for the direct control of these matters joint ministers for Foreign Affairs, for War, and for Finance.

\section{The Delegations}

The deliberative body of the dual monarchy is one of the most extraordinary political inventions of modern times. It consists of two delegations ${ }^{1}$ - one from Austria, the other from Hungary - each composed of sixty members, of whom twenty are chosen by the upper and forty by the lower house of each parliament. ${ }^{2}$ The delegations are reëlected annually, and must be summoned to meet by the Emperor at least once a year. In everything that relates to their sessions and procedure the most scrupulous regard is paid to the equality of the two countries. Their meetings, for example, are held alternately at Vienna and Buda-Pesth, ${ }^{3}$ and the proposals of the government are laid before both bodies at the same time. In the Austrian delegation all the proceedings are in German; in the Hungarian, in Magyar; ${ }^{4}$ while all communications between the two are made in both languages. It seems, indeed, to have been the object of the Hungarian statesmen, not only to maintain the equality of the two

1 Cf. The Austrian Law of Dec. 21, I867, §§ 6-35; Ulbrich, pp. 20-22; Gumplowicz, §§ 104-107.

2 One half as many substitutes are elected in the same way.

3 This is not required by the Act of Dec. $2 \mathrm{I}, \mathrm{I} 867$, which provides ( $\$$ II) simply that the meetings shall be held where the crown appoints, or, as the Hungarian Law ( $\left(3^{2}\right)$ says, where His Majesty is residing.

4 An exception is made in favor of the Croats, who are allowed to speak their own language. 
nations, but also to keep them apart, to avoid all appearance of a common parliament, for the delegations debate and vote separately except in a single case. If they disagree about any measure, and after the third exchange of communications an accord is not reached, either delegation may demand a common session. Here again the equality of the two countries is carefully preserved, for the two presidents take turns in presiding, the journal is kept in both languages, and, what is far more extraordinary, it is especially provided that the same number of delegates from each country shall take part, the side which has most members present being reduced by lot until the two are equal. In the joint session no debate is permitted, and the only business transacted is the taking of a vote on the matter about which the delegations have failed to agree. The procedure, therefore, is a peculiar one. The two bodies debate and vote separately, except in case of a deadlock, when they vote but never debate together.

It is important to observe that the delegations are practically confined in their action to voting supplies, and exerting a control over the administration. Those subjects, which in other federal governments fall within the province of the central legislature, are regulated in the dual monarchy by concurrent statutes of the two parliaments, and thus nearly everything in the nature of positive law must be enacted separately in Austria and Hungary. In substance, therefore, the whole joint legislation of the monarchy is a series of treaties, partly permanent and partly temporary, which cannot be changed or prolonged by any common legislature, but only by the contracting parties themselves. We have thus a unique case of almost absolute legislative decentralization, combined with a certain amount of administrative centralization, the laws on matters of common interest being en- 
acted by the separate legislatures, and only their execution being entrusted to the organs of the federal government. Hence the work of the delegations consists mainly in the control of the common administration, and in granting the annual appropriations.

\section{The Customs Union}

Except for a few insignificant matters, such as the lease of state property, the sale of old material, and the profits of the powder monopoly, the only direct source of revenue belonging to the joint government is the customs tariff, which rests upon a treaty between the two countries made for ten years at a time in the form of identical acts of the two parliaments. These laws establish a uniform tariff for the whole monarchy, and provide that neither country shall lay any duty on goods coming from the other, except to the amount of his own excise on the same commodity. The duties, however, although paid into the common treasury, are not collected by the joint government, but by the separate countries, which have nothing to do with each other's customhouses, except the right of mutual inspection.

\section{The Joint Ministers}

There are three joint ministries - those for foreign affairs, for war, and for finance. ${ }^{1}$ The Minister for Foreign Affairs is at the head of the diplomatic corps, and has entire charge of the foreign relations of both countries, for the separate halves of the monarchy hold no direct communication with other nations. He consults frequently, however, the premiers of Austria and Hungary, who, in turn, are often interpel-

1 The Minister for Foreign Affairs formerly bore the title of Imperial Chancellor, but the Magyars thought this savored too much of a consolidated state, and in $187 \mathrm{I}$ it was changed. 
lated and make statements on the subject in their respective parliaments. He also gives to the delegations such information as he thinks best; but from the secret nature of diplomatic negotiations his reports are necessarily far more meagre than those of the other ministers.

The next department of the joint administration is that of war, and here again is found the strange mixture of federal union and international alliance that is characteristic of the relations of Austria and Hungary. ${ }^{1}$ The regular army and the navy are institutions of the joint monarchy, although they are governed by separate standing laws of the two states, which are, of course, substantially identical. These laws determine, among other things, the number of the troops, and provide that the men shall be furnished by the two countries in proportion to population; but the contingent of recruits required from each country is voted annually by its own parliament. After the recruits are enlisted they are commanded and paid by the joint administration. The Emperor, as commander-in-chief, appoints the officers, and regulates the organization of the army. The minister of war, curiously enough, is not required to countersign acts of this nature, ${ }^{2}$ but he is responsible for all other matters, such as the commissariat, equipment, and military schools. Besides the regular army, which belongs to the joint government, there are military bodies, called in Austria the Landwehr, and in Hungary the Honveds, which are special institutions of the separate halves of the monarchy. These troops are composed of the recruits that are not needed for the contingents to the regular army, and of the men who have already served their time in it.

The third department of the joint administration is that of the finances, which caused no little trouble when the com-

1 Cf. Ulbrich, pp. $23^{-25}$.

${ }^{2}$ Law of Dec. 2I, I867, $\$ 5$. 
pact was made in 1867 . After a good deal of discussion it was finally settled that Hungary should contribute twentynine and a half millions of florins a year towards the interest on the existing debt, and that Austria should pay the rest, enjoying, however, the benefit of any reorganizations, or in other words repudiation, she might make - a privilege of which she subsequently took advantage in the form of a tax on the national creditors. In regard to the current expenses of the joint monarchy, it was finally arranged that they should be defrayed so far as possible out of the joint revenue, and that any balance should be paid, sixty-three and sixtenths per cent by Austria and thirty-six and four-tenths per cent by Hungary, that ratio being based upon the sums raised by taxation in the two countries.

\section{Bosnia and Herzegovina}

Curiously enough, there is a district which forms part neither of Austria nor of Hungary, but is ruled directly by the federal officials. ${ }^{1}$ The district did not belong to the monarchy when the compact of I 867 was made, but was acquired in 1878 , after the Russo-Turkish war. At that time the Great Powers met at the Congress of Berlin, and agreed to protect Turkey against the grasping ambition of Russia by lopping off pieces of her territory for the benefit of one another. Austria's share of the booty consisted of Bosnia and Herzegovina, and, although these provinces remained until I908 under the nominal suzerainty of the Sublime Porte, the administration of them being alone confided to Austria-Hungary they were virtually annexed for all purposes to the dominions of the House of Hapsburg. Now it would have been impracticable to divide the territory between Hungary and Austria, and neither half of the mon-

1 Ulbrich, pp. 27-28. 
archy would have consented to its annexation as a whole by the other. Hence the only possible course was to rule the provinces in common as a subject land. The two parliaments, therefore, passed laws providing that the administration of the provinces should be organized and carried on by the monarch and the joint ministers, reserving, however, to the cabinets of Hungary and Austria a right to an influence in the matter, that is, a right to be consulted in regard to it. Finally, after these provinces had been definitely annexed in I908, they were given a diet of their own to deal with local affairs.

\section{The Character of the Union}

If France has been a laboratory for political experiments, Austria-Hungary is a museum of political curiosities, but it contains nothing so extraordinary as the relation between Austria and Hungary themselves. The explanation of the strange connection is to be found in the fact that the two countries are not held together from within by any affection or loyalty to a common nation, but are forced together by a pressure from outside which has made the union an international and military necessity. The union has been, therefore, unavoidable, and it is very little closer than is absolutely necessary to carry out the purposes for which it exists. There is a common army, a common direction of foreign affairs, and a terminable customs union, which is, after all, the most convenient method of defraying part of the cost of the military establishment. There is no single authority that has power to settle anything, but every measure involves a negotiation between the two delegations or the two parliaments, and government becomes in consequence an endless series of compromises between bodies belonging to different races which are jealous of each other. Moreover, 
the source of legislation lies in the two parliaments, and to these the joint ministers have no access. It is in fact specially provided that they shall not be members of either cabinet. They are unable, therefore, to lead the parliaments; and that the parliaments cannot control them was clearly shown in 1878 , when the annexation of Bosnia and Herzegovina was carried through against the wishes of both legislatures. The ministers of Austria are at least nominally responsible to the lower house of the Reichsrath, and those of Hungary are actually responsible to the Table of Deputies, but the joint ministers are not in fact directly responsible to any legislative body. 
PRINTED AT

THE HARVARD UNTVERSITY PRESS

CAMBRIDGE, MASS., U.S. A. 



\section{UNIVERSITY OF CALIFORNIA LIBRARY}

Los Angeles

This book is DUE on the last date stamped below.

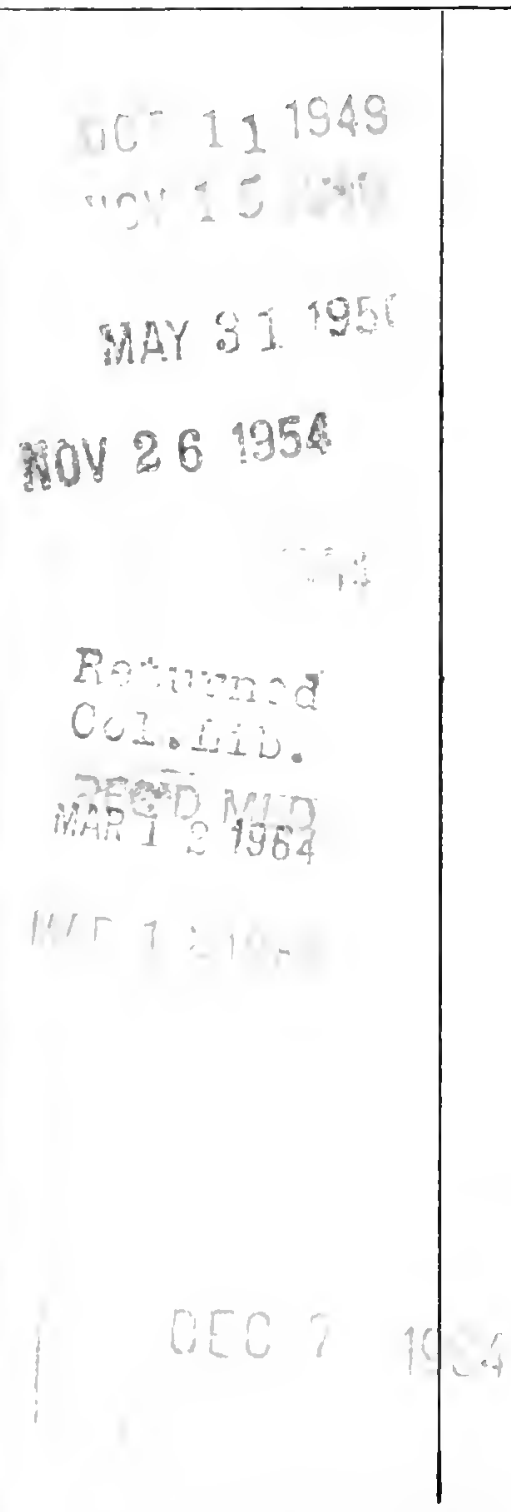

Form L9-42m-8, '49 (B5573) 444

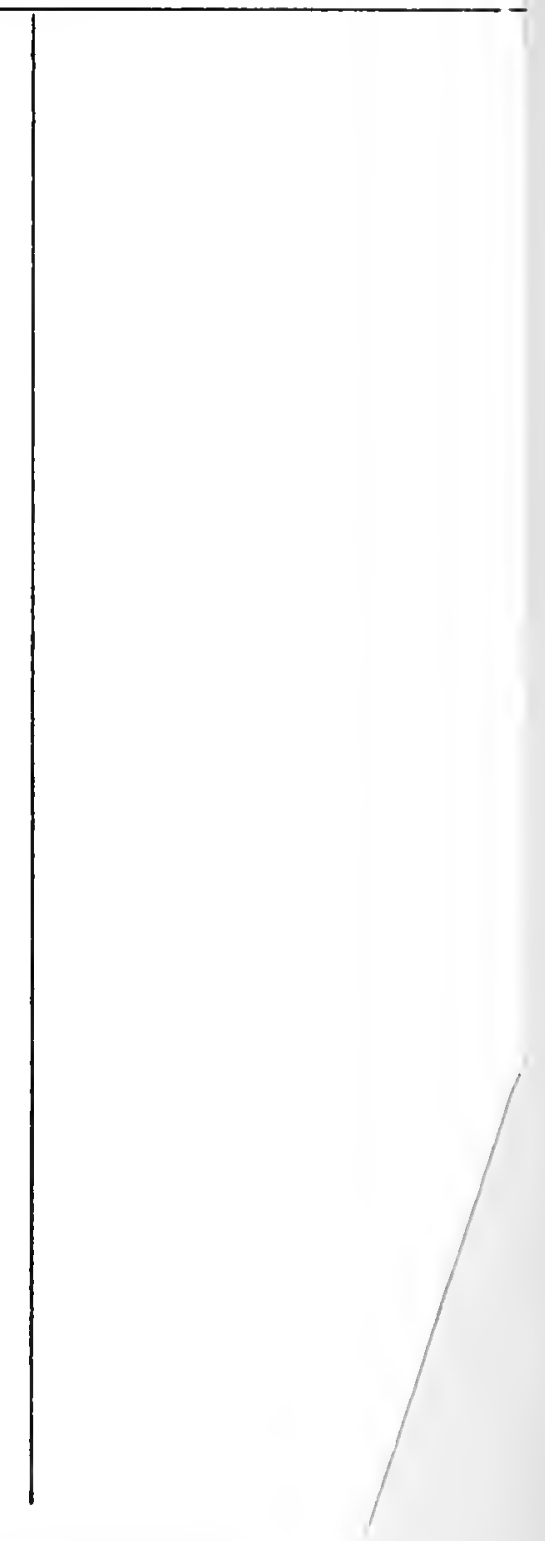


